\title{
ROYAL OPPORTUNITY: \\ NOBLE MARRIAGES IN THE REIGNS OF \\ ELIZABETH I AND JAMES VI/I, 1558-1625
}

\author{
BY \\ CHRISTIANNA FLOYD KAY
}

\begin{abstract}
A thesis
submitted to the Victoria University of Wellington in fulfilment of the requirements for the degree of Doctor of Philosophy
\end{abstract}

Victoria University of Wellington 



\section{Abstract}

This thesis explores Queen Elizabeth I's and King James VI/I's management of and involvement in noble marriages from 1558 to 1625 by merging two methodologies: an analysis of an extensive, custom-made database of 380 noble marriages with an examination of primary sources like state papers, personal correspondence, diaries, and ambassadorial reports. This study demonstrates that "noble-marriage management" was a single but efficient method for the implementation of many facets of early modern rule-this made it an important apparatus of the monarchical office and a significant conduit of power. Illuminated within this thesis are Queen Elizabeth's and King James's tactics for handling noble marital alliances which included participation and support, avoidance and opposition. They applied their exclusive crown privileges like plural prerogatives of wards' and widows' marriages and in loco parentis rights in attempts to control marital unions and they inaugurated new monarch-noble bonds through their patronage of weddings. They communicated religious, succession, and AngloScottish union policies, brought peace, and cultivated a crown-supportive aristocracy by means of their noble marriage involvement. Both monarchs employed multiple aspects of the royal prerogative to manage marriages which, at times, involved manipulating courts, bypassing Parliament, and prolonging punishments. Elizabeth and James also used the royal prerogative to forge their respective legacies of a Protestant kingdom and a unified England and Scotland. By utilising their exclusive privileges, both monarchs secured the freedom and power to intervene in noble marital alliances which preserved the hierarchical system of monarchy, achieving a pro-monarch balance of power and internal stability. In particular, it was through supportive involvement in marriages that Elizabeth and James perpetuated the patronage system and established allimportant monarch-noble connections which upheld royal authority. Monarchnoble links became especially important as parliamentary debates on the legitimacy and use of crown privileges increased in the Elizabethan and Jacobean periods, exposing both monarchs' absolutist tendencies. 



\section{Table of contents}

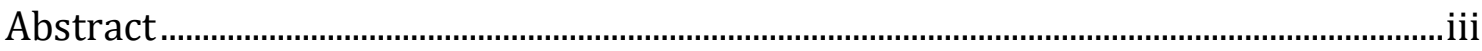

List of tables .......................................................................................................................

Acknowledgements ........................................................................................................ viii

Abbreviations and conventions.........................................................................................

Chapters

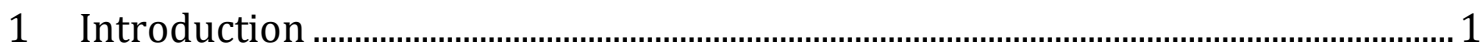

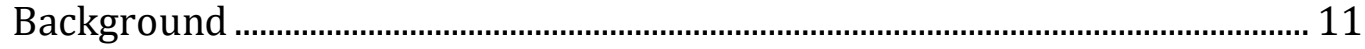

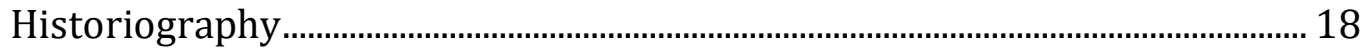

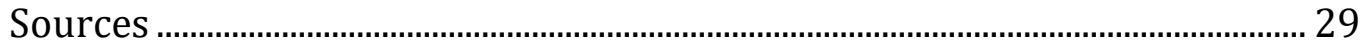

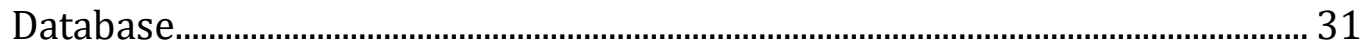

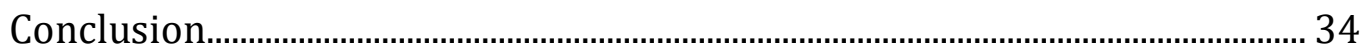

2 "By me princes rule, and nobles": the power behind noble-marriage

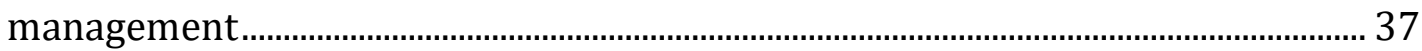

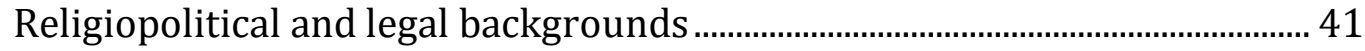

Plural prerogatives......................................................................................... 44

The royal prerogative .............................................................................................. 48

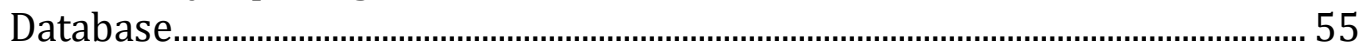

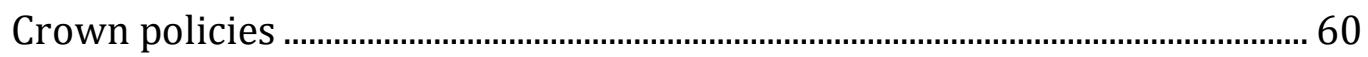

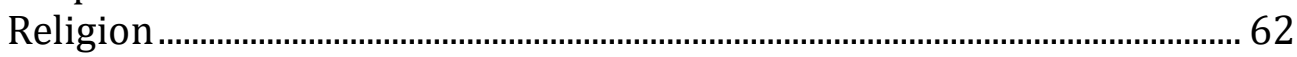

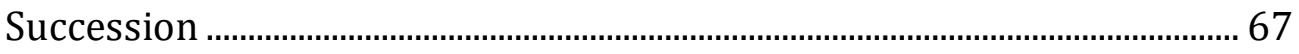

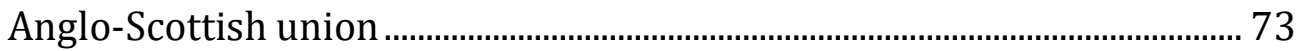

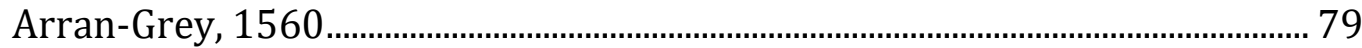

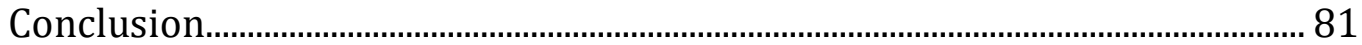

3 "Fêtes and banquets": monarchical support for noble marriages .......................... 83

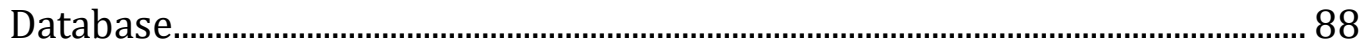

Elizabethan case studies

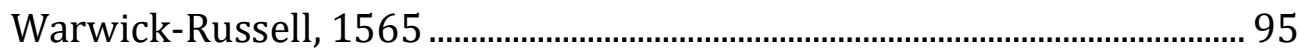

Oxford-Cecil and Herbert-Hastings, 1571..................................................... 97

Cumberland-Russell and Wharton-Clifford, 1577 .......................................102

Jacobean case studies

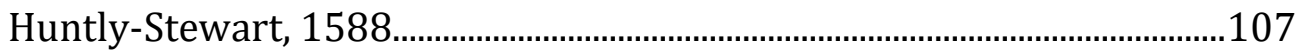

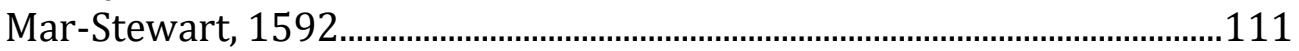

Essex-Howard, 1606..........................................................................................112

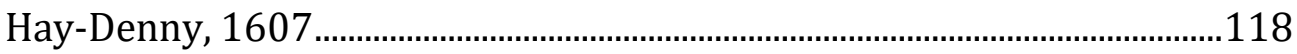

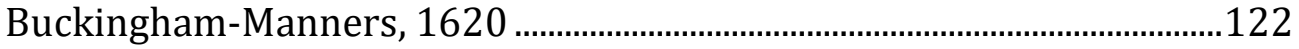

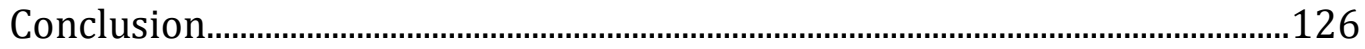

4 "Silent indecision"?: monarchical non-participation in noble marriages..........129

Database. 
Elizabethan case studies

Norfolk-Audley, 1558

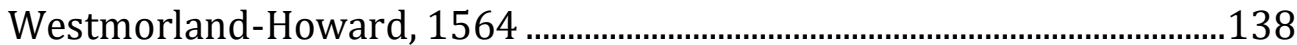

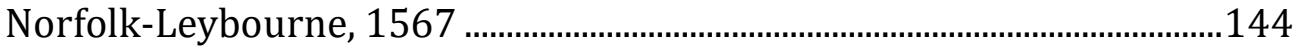

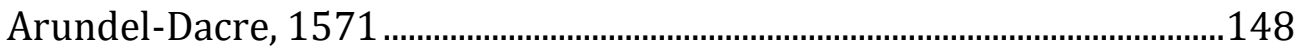

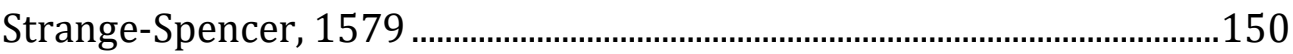

Jacobean case study

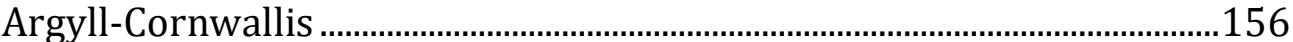

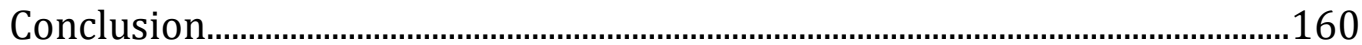

5 Nemo me impune lacessit: monarchical opposition to noble marriages.............165

Database.

Elizabethan case studies

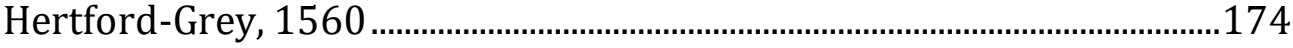

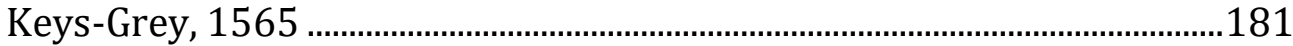

Lennox-Cavendish, 1574 ………..................................................................184

Jacobean case studies

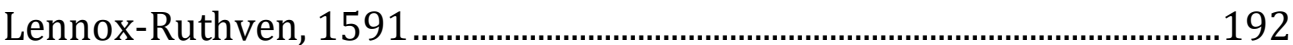

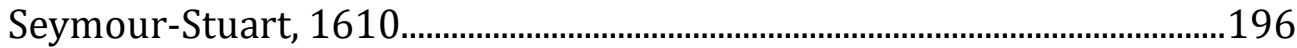

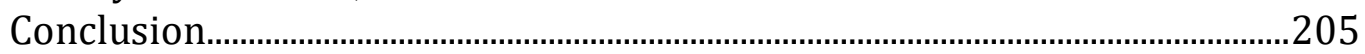

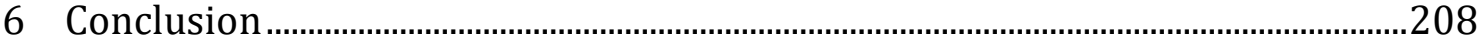

Appendix: Imputed noble-marriage involvement, 1558-1625 ..................................219

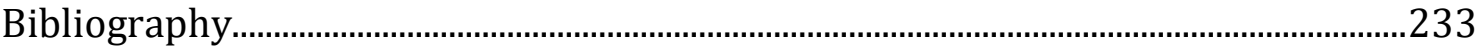




\section{List of tables}

2.1 Monarchical involvement in noble marriages ........................................................ 56

2.2 Monarchical involvement in noble marriages by strategy ...................................59

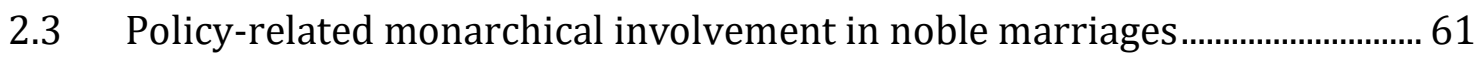

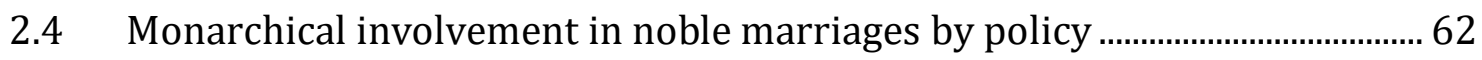

3.1 Supportive monarchical involvement in noble marriages ................................... 89

5.1 Clandestine noble marriages and monarchical opposition...............................172 


\section{Acknowledgements}

I owe tremendous debts of gratitude to my Ph.D. advisers, Dr Valerie Wallace, $\mathrm{Dr}$ Catherine Abou-Nemeh, and Professor Kate Hunter, for their thoughtful guidance and invaluable insight throughout my thesis preparation process. I have greatly valued their unwavering enthusiasm, patience, and support and feel very fortunate to have had them as my advisory team. Thank you! Any errors within are mine alone.

I am grateful for the Victoria University of Wellington History Programme's Postgraduate Seminar and the Early Modern Workshop, two groups which provided feedback on presentations and earlier drafts of this work.

I would also like to thank VUW History Librarian Justin Cargill and Professor Jim McAloon for their help. I am appreciative of the University of Auckland History Programme for granting me access to their online resources.

I reserve my greatest thanks for my parents and for my husband, Daniel, and our son, Ned, for their support and understanding throughout this lengthy and challenging endeavour. 


\section{Abbreviations and conventions}

$A C$
$A P C$
BL
Chamberlain
CJ
CP
$C P R$
$C S P D$

CSPF

CSPR

CSPSC

CSPSp

CSPV

D'Ewes

ECCO

ECW

EEBO

EHR
Church of England. The Anglican Canons, 1529-1947. Edited by Gerald Bray. Woodbridge: Boydell and Brewer, 1998.

Acts of the Privy Council of England. New series. Edited by John Roche Dasent. Vols. 7-39 (1558-1625). London: H. M. Stationery Office, 1893-1933.

British Library, London

Chamberlain, John. The Letters of John Chamberlain. Edited by Norman Egbert McClure. 2 vols. 1939. Reprint, Philadelphia: American Philosophical Society, 1962.

Journals of the House of Commons. Vol. 1 (1547-1628). London: H. M. Stationery Office, 1802.

Cecil Papers, Hatfield House, Hertfordshire, UK

Calendar of the Patent Rolls, Elizabeth I. Edited by Margaret Post and Ann E. Morton. Vols. 1-9 (1558-1582). London: H. M. Stationery Office, 1939-1986.

Calendar of State Papers, Domestic Series, of the Reigns of Edward VI, Mary, Elizabeth, James I (1547-1625). Edited by Robert Lemon and Mary Anne Everett Green. 12 vols. London: Longman, Brown, Green, Longmans, \& Roberts, 1856-1872.

Calendar of State Papers, Foreign Series, of the Reign of Elizabeth I. Edited by Joseph Stevenson, Allan James Crosby, Arthur John Butler, Richard Bruce Wernham. Vols. 1-22 (1558-1588). London: H. M. Stationery Office, 1863-1936.

Calendar of State Papers, Relating to English Affairs, Preserved Principally at Rome, in the Vatican Archives and Library. Edited by J. M. Rigg. Vols. 12 (1558-1578). London: H. M. Stationery Office, 1916-1926.

Calendar of the State Papers Relating to Scotland and Mary, Queen of Scots 15471603. Edited by Joseph Bain, William K. Boyd, Henry W. Meikle, Annie I. Cameron, and M. S. Giuseppi. Vols. 1-12 (1547-1597). Edinburgh and Glasgow: H. M Stationery Office, 1898-1952.

Calendar of Letters and State Papers Relating to English Affairs, Preserved Principally in the Archives of Simancas. Edited by Martin A. S. Hume. Vols. 14-17 (1558-1603). London: Eyre and Spottiswoode, 18921899.

Calendar of State Papers and Manuscripts, Relating to English Affairs. Existing in the Archives and Collections of Venice, and in Other Libraries of Northern Italy. Edited by Rawdon Brown, G. Cavendish Bentinck, Horatio F. Brown, and Allen B. Hinds. Vols. 7-18 (1558-1625). London: H. M. Stationery Office, 1890-1912.

D'Ewes, Simonds. The Journals of All the Parliaments During the Reign of Queen Elizabeth, Both of the House of Lords and House of Commons. London: Printed for John Starkey, 1682.

Eighteenth Century Collections Online

Elizabeth I. Elizabeth I: Collected Works. Edited by Leah Marcus, Janel Mueller, and Mary Beth Rose. Chicago and London: University of Chicago Press, 2000.

Early English Books Online

The English Historical Review 


\begin{tabular}{|c|c|}
\hline ELH & English Literary History \\
\hline FSL & Folger Shakespeare Library, Washington, D. C. \\
\hline HJ & The Historical Journal \\
\hline HMC & Historical Manuscripts Commission \\
\hline HMC, Bath & $\begin{array}{l}\text { HMC. The Manuscripts of the Most Honourable the Marquess of Bath Preserved } \\
\text { at Longleat, Wiltshire. Edited by Marjorie Blatcher and G. Dyfnallt } \\
\text { Owen. Vols. 4-5. London: H. M. Stationery Office, 1968-1980. }\end{array}$ \\
\hline $\begin{array}{l}\text { HMC, Mar and } \\
\text { Kellie }\end{array}$ & $\begin{array}{l}\text { HMC. Report on the Manuscripts of the Earl of Mar and Kellie, Preserved at Alloa } \\
\text { House, Clackmannanshire. Edited by Henry Paton. } 2 \text { vols. London: } \\
\text { H. M. Stationery Office, } 1930 .\end{array}$ \\
\hline HMC, Rutland & $\begin{array}{l}\text { HMC. Twelfth Report, Appendix, Part IV. The Manuscripts of His Grace the Duke } \\
\text { of Rutland, G.C.B., Preserved at Belvoir Castle. Vols. 1-2. London: H. M. } \\
\text { Stationery Office, 1888-1889. }\end{array}$ \\
\hline HMC, Salisbury & $\begin{array}{l}\text { HMC. Calendar of the Manuscripts of the Most Honourable the Marquis of } \\
\text { Salisbury, K. G., Preserved at Hatfield House, Hertfordshire. Edited by M. } \\
\text { S. Giuseppi, and D. McN. Lockie. Vols. 1-19 (1306-1607). London: } \\
\text { H. M. Stationery Office, 1883-1965. }\end{array}$ \\
\hline$J P C$ & $\begin{array}{l}\text { James VI/I. The Prince's Cabala: Or Mysteries of State. London: Printed for R. } \\
\text { Smith etal., } 1715 .\end{array}$ \\
\hline$J P W$ & $\begin{array}{l}\text { James VI/I. Political Writings. Edited by Johann P. Sommerville. Cambridge: } \\
\text { Cambridge University Press, } 1994 .\end{array}$ \\
\hline$L J$ & $\begin{array}{l}\text { Journals of the House of Lords. Vols. 1-3 (1509-1628). London: H. M. } \\
\text { Stationery Office, 1767-1830. }\end{array}$ \\
\hline$L K J$ & $\begin{array}{l}\text { James VI/I. Letters of King James VI and I. Edited by G. P. V. Akrigg. Berkeley: } \\
\text { University of California Press, } 1984 .\end{array}$ \\
\hline Lodge, 1791 ed. & $\begin{array}{l}\text { Lodge, Edmund. Illustrations of British History, Biography, and Manners: In the } \\
\text { Reigns of Henry VIII, Edward VI, Mary, Elizabeth, \& James I. Vol. } 3 . \\
\text { London: Sold by G. Nichol, } 1791 .\end{array}$ \\
\hline Lodge, 1838 ed. & $\begin{array}{l}\text { Lodge, Edmund. Illustrations of British History, Biography, and Manners: In the } \\
\text { Reigns of Henry VIII, Edward VI, Mary, Elizabeth, \&James I. } 2^{\text {nd }} \text { ed. } 3 \\
\text { vols. London: John Chidley, } 1838 .\end{array}$ \\
\hline$L Q E$ & $\begin{array}{l}\text { Elizabeth I. The Letters of Queen Elizabeth I. Edited by G. B. Harrison. London: } \\
\text { Cassell \& Company Ltd., } 1968 .\end{array}$ \\
\hline MEMSO & MEMSO 4.5: Medieval and Early Modern Sources Online \\
\hline Nichols, Elizabeth & $\begin{array}{l}\text { Nichols, John. The Progresses and Public Processions of Queen Elizabeth. } 3 \text { vols. } \\
\text { 1823. Reprint, New York: AMS Press, } 1969 .\end{array}$ \\
\hline Nichols, James & $\begin{array}{c}\text { Nichols, John. The Progresses, Processions, and Magnificent Festivities, of King } \\
\text { James I. } 4 \text { vols. 1828. Reprint, New York: AMS Press, } 1969 .\end{array}$ \\
\hline$O D N B$ & $\begin{array}{l}\text { Oxford Dictionary of National Biography. Online ed. Oxford: Oxford University } \\
\text { Press, } 2020 .\end{array}$ \\
\hline$O E D$ & Oxford English Dictionary. Online ed. Oxford: Oxford University Press, 2020. \\
\hline Pet. & Petition \\
\hline$R M$ & $\begin{array}{l}\text { Skene, John. Regiam Majestatem: The Auld Lawes and Constitutions of Scotland. } \\
\text { Edinburgh: Printed for John Wood, } 1774 .\end{array}$ \\
\hline$R P C$ & $\begin{array}{l}\text { The Register of the Privy Council of Scotland. Edited and abridged by David } \\
\text { Masson. Vols. 4-14 (1585-1625). Edinburgh: H. M. General Register } \\
\text { House, 1881-1898. }\end{array}$ \\
\hline$R P S$ & $\begin{array}{l}\text { Brown, K. M., et al., eds. The Records of the Parliaments of Scotland to 1707. St. } \\
\text { Andrews: University of St. Andrews, 2007-2020. }\end{array}$ \\
\hline$S C J$ & The Sixteenth Century Journal \\
\hline
\end{tabular}


SHR

Sidney Papers

SP

$S R$

Stuart, Letters

TNA

TRHS

Winwood
The Scottish Historical Review

Sidney, Henry, Sir. Letters and Memorials of State. Edited by Arthur Collins. 2 vols. London: Printed for T. Osborne, 1746.

State Papers

Great Britain. The Statutes of the Realm. Vols. 1-4. London: s.n., 1810-1828.

Stuart, Arbella, Lady. The Letters of Lady Arbella Stuart. Edited by Sara Jayne Steen. New York and Oxford: Oxford University Press, 1994.

The National Archives, Kew, London

Transactions of the Royal Historical Society

Winwood, Ralph, Sir. Memorials and Affairs of State in the Reigns of Q. Elizabeth and K. James I. Edited by Edmund Sawyer. 3 vols. London: W. B. for T. Ward, 1725

\section{Note on dates}

Dates are given in Old Style but with the New Year beginning on 1 January rather than 25 March. 


\section{Chapter 1}

\section{Introduction}

On a frosty St. Stephen's Day, 26 December 1613, Englishwoman Lady Frances Howard, with "her hair hanging loosely down," braved the cold and, being "led by her bridemen," processed towards the Chapel Royal at Whitehall Palace for her wedding. ${ }^{1}$ Awaiting her inside the church was Scotsman Robert Carr [Kerr], earl of Somerset, King James VI of Scotland and I of England's gentleman of the bedchamber and favourite courtier. ${ }^{2}$ This "magnificent marriage," organised by the king himself, gathered together the highest level of Jacobean society: "the King's Majesty and the Queen [Anne of Denmark], with the Prince [Charles] and all the Lords and Ladies of the Court and about London." After the ceremony, attendees were entertained in the Banqueting House at Whitehall with a "rich and costly" masque by Thomas Campion. ${ }^{3}$ Revelries continued for several more days as "the King, Prince, Bridegroom, and others ran at the Ring," and guests viewed a "scene" and later a masque, both Ben Jonson compositions. ${ }^{4}$ Estimated at nearly $£ 12,000$, contemporary John Chamberlain observed that the wedding presents the couple received "were more in number and value, than ever I think were given to any subject in this land." 5 The king's especial gift to the couple was his assumption of the wedding's cost "all saving the apparel," which demonstrated his approval of the couple, their wider kin groups, and the marriage itself. ${ }^{6}$

James's appearance at and participation in the Somerset-Howard wedding highlights numerous elements of the early modern monarchy: the importance of monarch-noble relations, the royal prerogative, the communication of crown

\footnotetext{
1 Edward F. Rimbault, ed., The Old Cheque-book, or Book of Remembrance, of the Chapel Royal, from 1561-1744 (Westminster: J. B. Nichols and Sons, 1872), 162; Nichols, James, vol. 2, 725n; Chamberlain, vol. 1, 487, 495. Lady Frances's bridemen were "a Duke of Saxony and [Henry Howard] the earl of Northampton her great uncle."

2 David Cressy, Birth, Marriage, and Death: Ritual, Religion, and the Life-Cycle in Tudor and Stuart England (Oxford: Oxford University Press, 1997), 336; Lodge, 1838 ed., vol. 3, 217; Chamberlain, vol. 1, 485; Nicholas Carlisle, An Inquiry into the Place and Quality of the Gentlemen of His Majesty's Most Honourable Privy Chamber (London: Messrs. Payne and Foss, 1829), 95.

${ }^{3}$ Chamberlain, vol. 1, 490, 496; Rimbault, ed., 166, 240; Nichols, James, vol. 2, 706, 707-714, 725.

${ }^{4}$ Nichols, James, vol. 2, 715, 719-724.

${ }^{5}$ Chamberlain, vol. 1, 496, 498; Anne Somerset, Unnatural Murder: Poison at the Court of James I (London: Phoenix, 2003), 245.

${ }^{6}$ Chamberlain, vol. 1, 487; Nichols, James, vol. 2, 704.
} 
policy, patronage, and the hierarchical and divine supremacy of the king. ${ }^{7}$ James's $^{\prime}$ backing of the Somerset-Howard marital union emerged publicly when he intervened as supreme governor of the church to ensure the annulment of Lady Frances Howard's first marriage, illustrated in chapter three. His intercession, which included convention of an ecclesiastical court and pressing judges to find a specific verdict, was a display of the royal prerogative-a privilege unique to the monarch as head of state which enabled independent action. Without James's intervention, the Essex-Howard marriage would have continued, thus preventing the Somerset-Howard union. The king's personal management of the nullity suit and Lady Frances's remarriage to Somerset reaffirmed the eminence of the Howard family and confirmed Somerset's position: "exceeding great with his Majesty... greater than any" ever seen. ${ }^{8}$

As an unmarried member of the royal household, James had an in loco parentis (in the place of a parent) duty to arrange and negotiate Somerset's marriage. Preferably it would be a union that would be beneficial to both the king and the earl. And, because James and the earl enjoyed a close, "emotionally intense" relationship, the king very likely wished the earl to be happily matched with a suitable bride. ${ }^{9}$ Somerset's wedding signalled James's partiality for AngloScottish intermarriage and served as a microcosm of the king's aspiration for "Britain," a unified Scotland and England. Despite the 1607 parliamentary failure of administrative union of his kingdoms, James promoted Anglo-Scottish marriages as an alternative-another expression of the royal prerogative. With the Somerset-Howard marriage, the king seized the opportunity to align his Scottish favourite with the influential English Howard family, pursuing his idea of Britain on an individual scale. In the process, he forged a bond between two powerful, pro-monarch court elements, binding them to each other and to himself. Because

\footnotetext{
7 This thesis uses the terms nobility, aristocracy, peer, and peerage interchangeably but refers specifically to those male subjects and their heirs who held the title of duke, marquess, earl, viscount, and baron or lord of Parliament (in Scotland). See Lawrence Stone, The Crisis of the Aristocracy, 1558-1641 (Oxford: Clarendon Press, 1965), $51,594$. However, I do this with caution regarding early modern Scotland following Professor Maureen Meikle's advice that titles were "fluid between greater lairds and named noble families." See Maureen Meikle, e-mail message to author, 11 March 2019; idem, "The Invisible Divide: The Greater Lairds and the Nobility of Jacobean Scotland," SHR 71 (1992): 70. In addition, some English women held a title in their own right and they are included in the database. Generally speaking, wives and daughters' titles were a courtesy based on the position of their husbands or fathers, respectively. Any exceptions to these parameters are footnoted.

${ }^{8}$ HMC, Mar and Kellie, vol. 2, 52, 41; Alastair Bellany, The Politics of Court Scandal in Early Modern England (Cambridge: Cambridge University Press, 2002), 53

${ }^{9}$ Bellany, 29.
} 
the marriage could only have occurred with the king's intervention and support, he effectively placed both parties under obligation to the crown, maintaining hierarchical dominance.

This thesis regards James's presence at the Somerset-Howard wedding as a "gift" to the newlyweds. This gift denoted an exchange between the two parties; the initiation of a new patron-client relationship between the monarch and the couple which coincided with pre-existing, individual patronage since it specifically recognised the link between the couple's families. Aristotle highlighted the appropriateness of bestowing gifts at transitional life events including births and marriages while the philosopher Seneca supplied parameters for gift-giving and patron-client relationships. ${ }^{10}$ The latter's De Beneficiis became an influential text in the early modern period as it provided guidance on reciprocity and gift-exchange. ${ }^{11}$ More recently, historians and anthropologists have researched the significance of gifts and their transmission. ${ }^{12}$ Marcel Mauss has stated that gifts "in theory [appear] voluntary, disinterested and spontaneous but are in fact obligatory and interested."13 Felicity Heal, in her research on gift-exchange in early modern England, has noted that "to give was to enter a cycle of reciprocation," which was "inherently transactional and intended to be mutual."14 In her studies on early modern patronage in France, Sharon Kettering has described gift-giving as a "polite fiction" which "concealed the bestowal of patronage."15 Similarly, Natalie Zemon Davis has observed that though gifts might express feelings of warmth or gratitude

\footnotetext{
${ }^{10}$ Aristotle, Nicomachean Ethics, trans. H. Rackham (Cambridge: Harvard University Press, 1926), 209, 211; Seneca, Moral Essays, vol. 3 (De Beneficiis), trans. John W. Basore (Cambridge: Harvard University Press, 1935), 19.

11 Multiple translations into English of Seneca's De Beneficiis appeared between 1569 and 1614 including Nicholas Haward, The Line of Liberalitie (London: Thomas Marshe, [1569]; Arthur Golding, The VVoorke of the Excellent Philosopher Lucius Annæus Seneca Concerning Benefyting (London: By [John Kingston for] Iohn Day, 1578; Thomas Lodge, The Workes of Lucius Annæus Seneca (London: Printed by William Stansby, 1614.

12 See, for example, Marcel Mauss, The Gift: The Form and Reason for Exchange in Archaic Societies, trans. Ian Cunnison (1950, reprint, London: Cohen \& West Ltd, 1966); Chris A. Gregory, Gifts and Commodities (London: Academic Press, 1982); Sharon Kettering, Patrons, Brokers, and Clients in Seventeenth-Century France (New York and Oxford: Oxford University Press, 1986); idem, "Gift-giving and Patronage in Early Modern France," French History 2 (1988): 131-151; idem, "The Historical Development of Political Clientelism," Journal of Interdisciplinary History 18 (1988): 419-447; Nicholas Thomas, Entangled Objects: Exchange, Material Culture, and Colonialism in the Pacific (Cambridge and London: Harvard University Press, 1991); Natalie Zemon Davis, The Gift in Sixteenth-Century France (Oxford: Oxford University Press, 2000), 13; Lorna G. Barrow, "'The Kynge sent to the Qwene, by a Gentylman, a grett tame Hart' Marriage, Gift Exchange, and Politics: Margaret Tudor and James IV 1502-13," Parergon 21 (2004): 65-84; Felicity Heal, The Power of Gifts: Gift Exchange in Early Modern England (Oxford: Oxford University Press, 2014).

13 Mauss, 1.

14 Heal, 29, 30.

15 Kettering, "Gift-giving," 137.
} 
"they also were simultaneously sources of support, interest, and advancement," characterised by "volition and obligation."16

More specifically, Lorna Barrow has placed gift-giving within the context of a royal marriage in her study of the 1513 wedding of Lady Margaret Tudor to King James IV of Scotland. Citing Patrick Geary, Barrow has shown that the receipt of gifts was not the purpose of patronage; rather it was "the establishment of bonds between giver and receiver."17 Gifts connected people to each other, holding society together through reciprocity. ${ }^{18}$ At the same time, the exchange of gifts sustained the social hierarchy because it was often asymmetrical and unequal. ${ }^{19}$ Still a gift could serve as "a political tool... [to] form closer association." 20 In this sense, Barrow has suggested that Lady Margaret became the "supreme gift" from England to Scotland to promote stronger ties between the two kingdoms. ${ }^{21}$ Likewise, James's gift of his presence at the Somerset-Howard marriage signified his desire for a closer association with the couple and their families as well as the expectation of reciprocity.

Furthermore, echoing Davis's work, Barrow has confirmed that gift-giving had religious and secular meanings in the sixteenth century. ${ }^{22}$ Because "the Lord was a party to all gifts, as the original supplier of everything humans have," gifts showed gratitude for one's blessings and joined the human with the divine. ${ }^{23}$ Seen in this light, when Somerset and Lady Frances made vows before God within the chapel, James's presence added another layer of meaning to those vows. ${ }^{24}$ The king's personal attendance conferred another holy blessing, apart from God's. This was due to the medieval notion of the divine right of kings which asserted that monarchs were God's chosen representatives on earth. ${ }^{25}$ In essence, Somerset and Lady Frances pledged devotion to each other and to God, and, by divine right, to their king.

\footnotetext{
16 Davis, 35.

17 Barrow, 80; Patrick Geary, "Sacred Commodities: The Circulation of Medieval Relics," in The Social Life of Things: Commodities in Cultural Perspective, ed. Arjun Appadurai (London: Cambridge University Press, 1986), 173.

18 Davis, 18; Aristotle, 281.

${ }^{19} \mathrm{Heal}, 13,39,87,91,108$.

20 Barrow, 68; Thomas, 7.

21 Barrow, 66.

22 Davis, 17-18, 100; Barrow, 67.

23 Davis, 100; Barrow, 67-68; Matt. 10:8 KJV.

24 Cressy, Birth, 338-339.

25 JPW, 181; G. R. Elton, ed., The Tudor Constitution: Documents and Commentary, $2^{\text {nd }}$ ed. (Cambridge: Cambridge University Press, 1982), 12.
} 
Heal has also touched a significant, related point in her description of the quasi-divine ceremony of the royal healing touch, particularly in the reign of King Charles I. According to Heal, the healing touch was a divine gift transmitted through the monarch and was, thus, unable to be fully reciprocated by the patient. Nevertheless, through the ceremony "the royal presence and promise of healing were exchanged for an affirmation of loyalty and acceptance of the personal power of monarchy." 26 Likewise, James's participation in the Somerset-Howard marriage ceremony linked the divine and human while it concurrently inferred the humanto-human connection of patronage. The king's payment for the wedding made clear his close bond with and approbation of the couple; his blessing upon them. It also heralded their commitment to loyalty and duty to the crown, echoing the royal healing touch ceremony.

At the time of the marriage, Somerset and Lady Frances individually enjoyed well-established patronage ties to crown which theoretically secured their fidelity. ${ }^{27}$ But, through his sponsorship of the Somerset-Howard marriage, James acknowledged the joining of their families by inaugurating a new patron-client relationship with the couple as representatives of their respective kin groups. Because this new bond was different, created expressly to salute amalgamating families, it existed alongside previous individual patronage links. Why was this necessary? As discussed in chapter three, because early modern England and Scotland were hierarchical, vertically-aligned societies, it was crucial for monarchs like James to recognise certain horizontal or lateral connections that marriages created, particularly those among the most wealthy and influential subjects. The research of Daniel McCormack and Niall Ferguson, in particular, has emphasised the intrinsically unstable nature of hierarchies and the threat lateral bonds might pose to these systems. ${ }^{28}$ Indeed, the partnering of noble families through marriage did create new horizontal links in society whereby combined strengths were established, the Carrs and the Howards, the Dudleys and the Russells, the

\footnotetext{
${ }^{26}$ Heal, 210. The royal healing touch ceremony was used by medieval and early modern English and French monarchs as a cure for scrofula. See Marc Bloch, The Royal Touch: Sacred Monarchy and Scrofula in England and France, trans. J. E. Anderson (London: Routledge and Kegan Paul, 1973).

27 CSPD, 1611-1618, 18, 43, 181, 205; HMC, Mar and Kellie, vol. 2, 41; Bellany, 29. Lady Frances had enjoyed the king's patronage of her first marriage in 1606 to Robert Devereux, third earl of Essex,, described in chapter three, as well as his strong support for her nullity suit.

28 DanielMcCormack, Great Powers and International Hierarchy (Cham: Palgrave Macmillan, 2019), 7; Niall Ferguson, The Square and the Tower (New York: Penguin Press, 2018), 39-40.
} 
Gordons and the Stewarts, the Stanleys and the Veres, for example. Each alliance or lateral connection became a new joint force with which the monarch had to contend. Illustrating this point is a letter written by Lady Russell prior to the Herbert-Russell marriage of 1600 :

I mean, God willing, on the $9^{\text {th }}$ of June, being Monday next, to fetch home my bride [her daughter, Anne]. I entreat none but such as be of the bride's and bridegroom's blood and alliance to supper that night. The Earl of Worcester with his Countess, the Earl of Cumberland with his Lady, the Lady of Warwick, the Earl of Bedford with his Lady will sup here. ${ }^{29}$

The number of upper-level noble families brought together by the Herbert-Russell marriage was impressive and Lady Russell herself referred to it as an "alliance." These families were near the pinnacle of the social hierarchy of the period and the alliances or lateral connections between them reveal the power and influence this kin group might wield as a whole. Once joined through the bonds of marriage, aristocratic families had the potential to become stronger and more influential. Supporting this idea, Lawrence Stone has indicated that "The marriages of this class might determine the social and political landscape of a county, or even the nation, and therefore became matters of high policy." 30 The lateral connections these weddings created in the vertical, hierarchical system of monarchy could serve or threaten the crown and, by extension, support or harm the well-being of the state. This is why the need to manage and become involved in them was not only critical but a key operation of the monarchical office; one which has remained under-researched.

James implemented multiple functions of the monarchical office through his oversight of the Somerset-Howard marriage. For example, he applied his exclusive rights like the royal prerogative and in loco parentis duty for the organisation of advantageous marital arrangements. He expressed crown policy, in this case his support for Anglo-Scottish union. He emphasised the divine and hierarchical aspects of monarchy as well as the notions of allegiance, obligation, and reciprocity associated with patronage. Each of these elements highlights the importance noble marriages had for the prevailing hierarchy, the perpetuation of monarchical rule

${ }^{29}$ CP, Vol. 186/134.

30 Stone, Crisis, 594. 
and supremacy, and raises questions about early modern monarchs' management and involvement in these alliances.

For instance, James's presence at the Somerset-Howard wedding prompts consideration of what rights the monarch had over marriages in the hierarchical societies of early modern England and Scotland. As fully discussed in chapter two, several powers permitted the monarch's involvement in weddings. For instance, the plural prerogatives of wards' and widows' marriages gave the king or queen the right to approve or deny potential partners to underage wards of the state or widows of the monarch's tenants-in-chief, often noblemen. Additionally, the monarch had an in loco parentis responsibility to manage the marriage prospects of single members of the royal household. Furthermore, the royal prerogative allowed for the manipulation of marriages which might further or undermine crown policies as well as the freedom to punish subjects despite lawfulness.

Further examination invites queries into what ways might James have supported other aristocratic marital unions besides the Somerset-Howard alliance and for what reasons? What factors might have triggered his response to a planned or already accomplished marriage? Was James alone in his approach to and management of noble marriages? How did other early modern monarchs, like James's predecessor in England, Queen Elizabeth I, supervise the marital alliances of their most powerful subjects-the nobility? Were particular strategies used? What other royal agendas or ideas might Elizabeth or James have attempted to express through pointed involvement in the weddings of the aristocracy? What benefits did monarchical involvement offer and what were the effects of intercession? And, finally, how and why did Elizabeth and James use the marriages of the nobility as outlets for numerous aspects of monarchical rule like prerogatives, patronage, and policy transmission?

By attempting to answer these questions and others, I am seeking a better understanding of early modern monarchy and monarch-noble relations. To that end, this thesis has several primary objectives. First, it identifies and delineates the practice of "noble-marriage management," specifically relating to the reigns of Queen Elizabeth I and King James VI/I. Then, it elucidates each monarch's process of handling aristocratic marital unions. At the same time it reveals that Elizabeth 
and James applied numerous tools of the early modern monarchy through their noble-marriage management processes for the maintenance of royal supremacy. These tools included the application of prerogatives, the granting of benefits, the initiation of patronage, and the communication of crown policies. Hence, this study demonstrates that the opportunities associated with the supervision of marriages were important to the early modern monarchical office. As the Somerset-Howard wedding reveals, a single noble marriage offered multiple possibilities for exercising monarchical power.

What exactly is meant by "noble-marriage management?" In the early modern period "stratagem" and, later, "strategy" meant a plan or a scheme devised to achieve a particular end. The term "management" had multiple meanings but could be understood as "organization, supervision, or direction; the application of skill or care in the manipulation, use, treatment, or control (of a thing or person), or in the conduct of something." 31 Bearing in mind these early definitions, I have defined noble-marriage management as the monarch's dynamic supervision of and manipulation of marital alliances of the nobility which included evaluating those marriages and deciding whether or not to intervene. Keith Brown has observed that "all rulers, even popes, interfered in the marriage market." 32 However, this thesis and its core database provide a more nuanced view of monarchs' selfinterested meddling in aristocratic marriages. Fundamental to this argument, a purpose-built database delivers statistics drawn from more than 14,000 entries relating to 380 noble marriages. A significant source of evidence, the database allows for methodical retrieval of information, figures, and trends on the process of noble-marriage management, particularly on policy-related involvement and patronage. Indeed, the patronage connections Elizabeth and James established at weddings by means of crown privileges were significant for enhancing monarchnoble relations. These links became vital as the legitimacy of monarchical benefits increasingly drew criticism from the House of Commons. This thesis and its dualevidentiary platform will bring to light the critical place noble-marriage management had as an apparatus of the monarchy employed to maintain royal supremacy, influence monarch-noble relations, and convey crown agendas.

31 OED, s.v. "stratagem, n.;" ibid, s.v. "strategy, n.;" ibid, s.v. "management, n."

32 Keith M. Brown, Noble Society in Scotland: Wealth, Family and Culture, from Reformation to Revolution (Edinburgh: Edinburgh University Press, 2000), 126. 
In his 1599 Basilikon Doron, a manual on kingship written for his son, King James described marriage as "one of the greatest actions that a man doeth in all his time." Because of the importance of wedlock, the king counselled his heir that "Marriage is the greatest earthly felicity or misery, that can come to a man... ye must be careful both in your preparation for it, and in the choice and usage of your wife." 33 James was not alone in offering advice. Numerous works published in the sixteenth and seventeenth centuries in England and Scotland provided information on various aspects of marriage and married life. This guidance included the true meaning of marriage, how a married couple should live, and how to select a wife. ${ }^{34}$ In the early modern period marriage was a fundamental aspect of life; "to be fully a member of adult society... meant to be married."35 Matrimony ushered children into maturity, confirming their identities as adults and as fully-fledged members of a coalition of kin, and it allowed for the continuance of the family line. In addition, as Davis has noted, marriage created multiple vertical and horizontal bonds: husband-to-wife, kin group-to-kin group, and couple-to-community, for example. ${ }^{36}$ The Somerset-Howard marriage, in particular, demonstrated the important, if also vertical and unequal, monarch-to-noble alliance.

The royal court, as the meeting place for the country's most influential subjects, was where families might consider joining forces via marriage. A carefully-planned marriage allowed families to consolidate land and properties in a particular region or to add new wealth to dwindling estates. In 1591, the fourth earl of Worcester arrived at the English court with his four daughters, "all marriageable," and at least two of them went on to serve in Queen Elizabeth I's household..$^{37}$ Court service to the king or queen opened doors to potential marital

\footnotetext{
$33 \mathrm{JPW}, 41,38$.

34 In addition to James's Basilikon Doron, other printed examples of matrimonial advice include Anonymous, The Order of Matrimony (London: Anthony Scoloker, 1549); Heinrich Cornelius Agrippa von Nettesheim, The Commendation of Matrimony, trans. David Clapham (London: 1540); Thomas Becon, The Worckes of Thomas Becon, vol. 1 (London: John Day, 1564), 588-697; Heinrich Bullinger, The Christen State of Matrimonye (London: Nycholas Hyll for John Wayght, 1552); idem, The Golde Boke of Christen Matrimonye, trans. Miles Coverdale (London: Ioh[a]n Mayler for Ioh[a]n Gough, 1542); William Whately, A Bride-bush: or, a Direction for Married Persons (London: Felix Kyngston, 1619).

35 Eric Josef Carlson, Marriage and the English Reformation (London: Blackwell, 1994), 106. See also Olwen H. Hufton, The Prospect Before Her: A History of Women in Western Europe (New York: Knopf, 1996), 64.

36 Davis, 47.

37 TNA, SP 12/243/180; Charlotte Merton, "The Women Who Served Queen Mary and Queen Elizabeth: Ladies, Gentlewomen, and Maids of the Privy Chamber, 1553-1603" (Ph.D. diss., Cambridge University, 1992), 138; Arthur F.
} 
alliances and royal patronage that would benefit oneself and one's familial networks. Indeed, when parents sent their son or daughter to court, it was with the hope that he or she might make a gainful match there. The rewards of chamber service could be great but the duties were all-consuming, demanding one's full attention as the ruler's needs were placed above everything else. The fifth earl of Rutland advised his niece who had been invited to join Queen Elizabeth's household to "apply yourself wholly to the service of her Majesty with all meekness love and obedience; wherein you must be diligent, secret and faithful." 38 Absence from court was allowed only in times of serious illness, or, for married women, at the very final stage of pregnancy. ${ }^{39}$ Marriage provided the only other way for men and women to leave their sovereign's service. ${ }^{40}$ One mother lamented, "I do hear such ill report of the Court as I would be glad to have her [daughter] from that place, the which by no means can be done but by marriage." 41 Nevertheless, the court served as an important location for the nobility to find a potential mate and to build a lasting partnership that would benefit many.

Marriage was a key event not just in the betrothed's life but also in the lives of his or her extended family members. From the perspective of the nobility, the highest ranking and often the most wealthy and influential members of society, one's marital partner was of tremendous importance. Historian Barbara Harris has noted that "Marriage and kinship formed the basis of the patron/client relations at the centre of early Tudor politics;" weddings were used "to forge or strengthen... links to other aristocratic families, and to increase the wealth, power, and status of their patrilineages." 42 Sixteenth-century writer Heinrich Cornelius Agrippa von Nettesheim, however, eschewing the prevailing practice of basing marriage on the amalgamation of wealth and property, recommended that "Thou therefore, who so ever thou art, that will take a wife, let love be the cause, not

Kinney, ed., Titled Elizabethans: A Directory of Elizabethan Court, State, and Church Officers, 1558-1603, 2nd ed., rev. Jane A. Lawson (New York: Palgrave Macmillan, 2014), 31, 35.

38 HMC, Rutland, vol. 1, 275, 278; Susan Doran, Elizabeth I and Her Circle (Oxford: Oxford University Press, 2015), 206, 213 [hereafter Doran, Circle].

39 See Alison Wall, "For Love, Money, or Politics? A Clandestine Marriage and the Elizabethan Court of Arches," HJ 38 (1995): 515.

${ }^{40}$ Anna Whitelock, Elizabeth's Bedfellows: An Intimate History of the Queen's Court (London: Bloomsbury, 2013), 21; Sidney Papers, vol. 2, 188.

41 HMC, The Manuscripts of His Grace the Duke of Portland, vol. 9 (London: H. M. Stationery Office, 1891), 150.

42 Barbara J. Harris, “Women and Politics in Early Tudor England,” HJ 33 (1990): 260. 
substance of goods." 43 Nonetheless, material goods, power, and influence continued as important aspects of marriage negotiations, especially among the nobility in England and Scotland. ${ }^{44}$ The lateral connections established at aristocratic weddings brought powerful court figures together, consolidating wealth or power and creating kinship ties between them-ties that might potentially supersede their loyalty to the crown and prove detrimental to the hierarchical system dominated by the monarch. As a result, noble marital alliances were of great significance. And so was the monarch's need take advantage of opportunities to manage them prudently due to their potential effect on multiple aspects of society-hierarchical, political, social.

\section{Background}

In the early modern monarchy all aspects of government hinged upon the royal person-his or her abilities, intelligence, skills, and moods all influencing the nature and effectiveness of rule-which made it a personal monarchy. And so it was with Elizabeth's and James's monarchies but neither ruled alone. The monarch's relationship with the nobility was critical for strengthening personal rule and, like the monarchy, the nobility was dynastic and hierarchical. The crown's ability to offer patronage to and work effectually with the nobility was necessary for successful governing and a peaceable kingdom. Many early modern historians of England and Scotland like Stone and Brown, George Bernard and Pauline Croft, for example, have confirmed the significance of this relationship between the monarch and his or her aristocracy for stability and fostering allegiance to the crown. ${ }^{45}$ At its core, this dissertation is about monarch-noble relations, specifically the interactions between Elizabeth and James and their respective aristocracies as viewed through the latter group's marriages The nobility were the crown's natural allies and supporters. They were, as Stone

${ }^{43}$ Nettesheim, 17-18.

${ }^{44}$ Keith M. Brown, Kingdom or Province?: Scotland and the Regal Union, 1603-1715 (New York: St. Martin's Press, 1992), 40.

45 See, for example, Miles Kerr-Peterson and Steven J. Reid, eds., James VI and Noble Power in Scotland 1578-1603 (London and New York: Routledge, 2017), 2-3; Keith M. Brown, Noble Power in Scotland from the Reformation to the Revolution (Edinburgh: Edinburgh University Press, 2011), 2; George Bernard, Power and Politics in Tudor England (Aldershot: Ashgate, 2000), 44-45; John Guy, ed., The Tudor Monarchy (London: Arnold, 1997), 2; T. E. Hartley, Elizabeth's Parliaments: Queen, Lords, and Commons, 1559-1601 (Manchester and New York: Manchester University Press, 1992), 6; Linda Levy Peck, "Court Patronage and Government Policy: The Jacobean Dilemma," in Patronage in the Renaissance, ed. Guy Fitch Lytle and Stephen Orgel (Princeton: Princeton University Press, 1981), 27-28 [hereafter Peck, "Jacobean Dilemma”]; Pauline Croft, King James (Basingstoke: Palgrave Macmillan, 2003), 31; Elton, ed., 247; Stone, Crisis, 64 . 
described, "a power élite" who formed a tremendous and crucial part of the government apparatus, serving in the House of Lords in England and the second estate in Scotland, as privy councillors, as crown representatives in the counties and abroad, and in the royal household. ${ }^{46}$ Thus, it was necessary, according to Bernard, that "the relationship between Crown and nobility was one of cooperation." 47

Both Elizabeth and James had a clear understanding of the aristocracy's importance to their position and authority. They may have recalled Niccolò Machiavelli's observation that "wise princes have always taken great pains not to exasperate the nobles."48 In her first speech to Parliament Elizabeth touched on her relationship with the nobility: "so I shall desire you all, my Lords (chiefly you of the nobility, every one in his degree and power), to be assistant to me that I with my ruling and you with your service." 49 Likewise, in Basilikon Doron James described the valuable relationship which existed between the monarch and nobility:

honour them therefore... Peers and Fathers of your land: the more frequently that your Court can be garnished with them, think it the more your honour; acquainting and employing them in all your greatest affairs; since it is, they must be your arms and executers of your laws. ${ }^{50}$

The monarch needed the nobility for advice and counsel, for parliamentary backing in the House of Lords or the second estate, for military support-the men and arms noblemen could muster, and for the extension of crown policies to the outer reaches of the realm-to noblemen's individual spheres of influence. At the same time, the monarch needed to prevent the aristocracy from becoming "overmighty subjects," from developing power and sway enough to threaten the crown.51 This would contradict the purpose and chief responsibilities of the monarch: "the direction of the people, and the management of the public-weal."52

\footnotetext{
${ }^{46}$ Stone, Crisis, 64. See also Susan Doran and Norman Jones, eds., The Elizabethan World (London and New York: Routledge, 2011), 19, 20; Roger Lockyer, Tudor and Stuart Britain, 1485-1714, 3rd ed. (London: Routledge, 2014), 229 [hereafter Lockyer, Britain]; Hartley, 6.

47 Bernard, 45.

48 Niccoló Machiavelli, The Prince, trans. George Bull (London: Penguin Books, 1961), 105.

${ }^{49} E C W, 52$.

$50 \mathrm{JPW}, 29$.

51 John Fortescue, The Governance of England, ed. Charles Plummer (Oxford: Clarendon Press, 1885), 127.

52 Edmund Plowden, The Commentaries, or Reports, vol. 1 (Dublin: Printed for H. Watts, 1792), 213. See also JPW, 20;

John Miller, ed., Absolutism in Seventeenth-Century Europe (Basingstoke and London: Macmillan, 1990), 197.
} 
Elizabeth herself remarked, in reference to the possibility of her marriage, that her duty was to preserve peace for her subjects, "I will never... conclude anything that shall be prejudicial to the realm, for the weal, good, and safety whereof I will never shame to spend my life."53 Correspondingly, James, in his 1604 speech to the English Parliament promised "the certain continuance of peace" as well as the desire to establish "Peace within." 54 As a result, monarchs like Elizabeth and James needed to handle prudently their relationships with the nobility to cultivate harmony and stability but also to maintain their hierarchical dominance. This thesis argues that one way in which they did this was by carefully managing the marital alliances that took place within that social group.

As the monarch looked to the nobility for guidance, assistance, and enforcement, so the nobility relied upon the monarch for support, advancement, and wealth. They regarded the monarch as "not only the source of power but also as the fountain of grace, which flowed for their benefit." 55 As the source of bounty and generosity, it was the monarch's duty to reward his or her subjects in the form of patronage and the nobility depended upon these rewards. ${ }^{56}$ Already touched on, patronage, in its most basic sense, was a form of gift-giving. ${ }^{57}$ Patronage existed in most societies to link multiple levels of society. ${ }^{58}$ It was used in early modern European courts to create a bond between the monarch, the ultimate patron, and his or her client. ${ }^{59}$ Kettering has described the patron-client relationship as

a personal, direct exchange in which a patron uses patronage resources he himself owns or controls on behalf of his clients: he assists and protects his clients, giving them material benefits, opportunities for career advancement, and protection from the demands of others. 60

Along with Heal, Kettering, Davis, and Barrow, Wallace MacCaffrey and Linda Peck have explored the workings of the Tudor and early Stuart England patronage systems, respectively, and how they were closely intertwined with the political

\footnotetext{
53 ECW, 57

$54 \mathrm{JPW}, 134$.

55 Linda Levy Peck, ed., The Mental World of the Jacobean Court (Cambridge: Cambridge University Press, 1991), 22.

56 Linda Levy Peck, "'For a King Not to be Bountiful Were a Fault': Perspectives on Court Patronage in Early Stuart England," Journal of British Studies 25 (1986): 36.

57 Kettering, "Gift-giving," 131; Peck, "'For a King," 34; Barrow, 67.

58 See, for example, Mauss, The Gift; Gregory, Gifts and Commodities; Kettering, Patrons; idem, "Gift-giving," idem, "Political Clientelism;" Thomas, Entangled Objects; Davis, The Gift; Barrow, "Marriage, Gift Exchange, and Politics."

${ }^{59}$ See David Harris Sacks, "The Counterveiling of Benefits," in Tudor Political Culture, ed. Dale Hoak (Cambridge: Cambridge University Press, 2002), 285; Davis, 13; Heal, 17-19.

60 Kettering, "Political Clientelism," 425.
} 
system. ${ }^{61}$ MacCaffrey has observed that patronage under the Tudors evolved into a new system which kept power in the hands of the king. It became more reliant on professional men valued for their intelligence and ability rather than the nobility. When Elizabeth ascended the throne she was the "one universal patron," all benefits and perquisites emanated from her. ${ }^{62}$ Peck has also linked the centrality of James to patronage distribution in early seventeenth-century England. ${ }^{63}$ But, unlike Elizabeth, James had two aristocracies to reward, those of Scotland and England.64 In doing so, as both Peck and Croft have noted, James cultivated closer connections between the aristocracy and himself by patronising their marriages. ${ }^{65}$

The reverse of patronage was clientage, the "loyal service that a client owed [a patron] in exchange, sometimes disguised as voluntary assistance," and often expressed in the "chivalric rhetoric of loyalty." Fidelity and trust were key elements of the patron-client relationship, with Kettering remarking that "a patron did not tolerate disloyalty from his clients."66 Additionally, political scientist Henry Farrell's research is relevant to the asymmetrical power structure that existed in the hierarchical societies of early modern England and Scotland and in patronclient relationships. He has observed that "while disparities in power may certainly affect the way in which the proceeds of trust-based cooperation are distributed, they will not necessarily prevent trust from arising." 67 In-built tension, the result of power inequality, was a natural characteristic of hierarchies and patron-client relationships, rendering them inherently precarious. ${ }^{68}$ Nonetheless, trust was both possible and essential for stabilising hierarchies and for successful patron-client relationships, imbalanced though the power structures were. The

\footnotetext{
61 See Wallace T. MacCaffrey, "Patronage and Place in Elizabethan Politics," in Elizabethan Government and Society, ed. S. T. Bindoff, J. Hurstfield, and C. H. Williams (London: University of London, 1961), 95-126; idem, The Shaping of the Elizabethan Regime (Princeton: Princeton University Press, 1968); idem, Queen Elizabeth and the Making of Policy, 1572-1588 (Princeton: Princeton University Press, 1981); idem, "Patronage and Politics under the Tudors," in The Mental World of the Jacobean Court, ed. Linda Levy Peck (Cambridge: Cambridge University Press, 1991), 21-35; Linda Levy Peck, Northampton: Patronage and Policy at the Court of James I (London: George Allen \& Unwin, 1982); idem, Court Patronage and Corruption in Early Stuart England (London: Routledge, 1993); idem, "Jacobean Dilemma," 27-46; idem, "'For a King,"' 31-61; Peck, ed., Mental World.

62 MacCaffrey, "Patronage and Politics," 28.

63 Peck, "Jacobean Dilemma," 28-29.

64 Peck, “'For a King," 38.

65 Peck, Court Patronage, 71; Croft, King James, 66-67.

66 Kettering, "Gift-giving," 132, 136-137.

${ }^{67}$ Henry Farrell, "Trust, Distrust, and Power," in Distrust, ed. Russell Hardin (New York: Russell Sage Publications, 2004), 86.

68 Kettering, “Political Clientelism,” 425; McCormack, 7.
} 
monarch's encouragement of clientage, obedience, loyalty, and trust was prudent statecraft as it maintained royal supremacy and promoted harmony, thus, fulfilling the early modern ruler's duties of safeguarding the people and the commonweal. As Giovanni Botero observed in his Reason of State (1589), a prince should maintain his superiority and "grandeur almost heavenly and divine" to preserve the disparity of power "because (as Livy says) Vinculum fidei est melioribus parere (The bond of loyalty is to obey one's betters)."69

Monarchical patronage and noble clientage continued as long as service was rewarded, making the duration of patron-client associations highly significant. Long-term relationships were valuable because they created stability and signalled that members of the nobility were on good terms with the monarch and vice versa. Short-lived patron-client relationships indicated the opposite. Despite its auspicious beginning, the patron-client link James inaugurated at the SomersetHoward wedding lasted less than three years. In 1616 the earl and countess were placed on trial and found guilty of the 1613 murder of Somerset's secretary, Sir Thomas Overbury. Though they were sentenced to death, James pardoned them. The Somersets remained in the Tower until 1622 and never returned to favour. ${ }^{70}$ The termination of a patron-client bond, other than due to death, represented an "imbalance in reciprocity:" services had not been rewarded, responsibilities had been ignored. ${ }^{71}$ Broken patron-client ties also indicated a "collapse of trust."72 As the lynchpin in the patronage system, the ultimate responsibility for severed ties generally lay with the monarch though, in the case of the Somersets, a criminal act which brought disrepute to the monarch was an exception This thesis examines the temporal duration of the monarch-noble patron-client relationships that Elizabeth and James established with their personal attendance at or supportive involvement in noble marriages. It argues that successful patronage was that which remained intact from the point of marriage until either the monarch's death or the death of the bride or groom and did not collapse at any point. Whether longor short-term, patron-client associations reveal the effectiveness of Elizabeth's and James's overall patronage efforts.

69 Giovanni Botero, The Reason of State, ed. Robert Bireley (Cambridge: Cambridge University Press, 2017), 15-16; Maurizio Viroli, From Politics to Reason of State (Cambridge: Cambridge University Press, 1992), 256.

70 Chamberlain, vol. 2, 13, 17, 421, 582; Howell, ed., vol. 2, 951-1021; Bellany, 36-56.

71 Kettering, "Gift-giving," 132, 143.

72 Ian Mortimer, 1415: Henry V's Year of Glory (2009; reprint, London: Vintage Books, 2010), 150. 
Using their exclusive crown privileges, Elizabeth and James established patron-client relationships with their respective aristocracies and built their patronage networks. Discussed in chapter two, exclusive crown privileges like plural prerogatives and the royal prerogative had financial aspects which supplemented often insufficient royal coffers and also benefitted the nobility. ${ }^{73}$ The crown sold wardships, wards' marriages, and licenses for widows' marriages, each associated with plural prerogatives. ${ }^{74}$ Members of the nobility were regular buyers, especially as they could generate funds from wards' estates and marriages. ${ }^{75}$ The royal prerogative upheld other crown benefits or benevolences sought by subjects for their lucrativeness: leases, patents of monopoly, impositions, rent charges, titles, pensions, annuities, lands, and offices. ${ }^{76}$ Monopolies on everyday goods like salt, starch, and vinegar, in particular, led to higher prices and public outcry, calling into question their legality and benefit to the commonwealth. During English Parliaments summoned between 1571 and 1624, the House of Commons repeatedly questioned prerogatives like purveyance, wardship, impositions, and monopolies which both Elizabeth and James believed were their exclusive monarchical rights. ${ }^{77}$ Little comment was made in the House of Lords, however; its members being frequent recipients of these privileges as gifts. ${ }^{78}$ Many of the nobles described below received crown benefits like titles, offices, charters, leases, or properties. Indeed, Elizabeth and James used their privileges to grow not only their dominance and financial independence but also their structure of support: monarch-noble patron-client relationships. Establishing long-term patronage bonds with their aristocracies upheld their authority but it also attracted the criticism of the Commons which, in turn, made the monarch-noble bonds even more critical for royal rule.

The uneven relationship of patronage and clientage meant that the monarch held power over the nobility. But the monarch needed and trusted the nobility to

\footnotetext{
73 J. P. Kenyon, ed., The Stuart Constitution 1603-1688: Documents and Commentary, 2nd ed. (Cambridge: Cambridge University Press, 1986), 7.

74 SR, vol. 1, 115: 25 Edw. I, 1297, Magna Carta, c. 4.

75 Joel Hurstfield, The Queen's Wards: Wardship and Marriage under Elizabeth I, 2nd ed. (London: Frank Cass, 1973), 60, 66.

76 Sacks, 273; Stone, Crisis, 604.

77 D’Ewes, 86, 158, 160, 412, 554, 645-654; Elton, ed., 311-312, 323-325; David L. Smith, The Stuart Parliaments 16031689 (London: Arnold, 1999), 104, 106, 109, 111; Pauline Croft, "Fresh Light on Bate’s Case," HJ 30 (1987): 523; Kenyon, ed., 47-50.

78 Conrad Russell, James VI and I and His English Parliaments, ed. Richard Cust and Andrew Thrush (Oxford: Oxford University Press, 2011), 183; Sacks, 273, 277.
} 
represent his or her interests outside of the court. A letter from Elizabeth to the earl of Ormonde specifically referred to the importance of the nobility's representative role:

you, that are of noble blood and birth, will so carry all things in the manner of your proceedings, as our honour may be specially preserved in all your actions, seeing you do know that you now represent our own person. ${ }^{79}$

Often, the noble transmitters of government policies were, as Diarmaid MacCulloch has observed, "familiar faces at Court... but also trusted and respected members of the county." Their function was particularly vital when viewed from a revenue standpoint. ${ }^{80}$ Monarch-noble patron-client relationships connected the court to the counties and were the means by which government business was accomplished. No standing military or professional bureaucracy existed to implement policies-many government officials received only token payment or none at all. ${ }^{81}$ The crown relied on the counties for funding; the taxes collected from them supported government operations. ${ }^{82}$

Along with MacCulloch and Peck, historians Simon Adams, Catheryn Enis, Stephen Hollings, and Alison Wall have studied different aspects of the monarch and noble patronage links which connected the court to the counties. ${ }^{83}$ Their research has shown that it was not only imperative for the monarch to establish patron-client relationships with noblemen who had influential positions in the counties and would work to the benefit of the crown, it was critical that these relationships remained on good terms and were enduring. Otherwise, the monarch's coffers could be found empty and his or her policies ignored. ${ }^{84}$ In her study of Henry Howard, earl of Northampton, and Jacobean patronage, Peck has written that "the divorce of patronage from policy... was dysfunctional," and led to abuses, waste, loss. While Peck's statement has specifically related to the

${ }^{79} L Q E, 256$.

80 Diarmaid MacCulloch, Suffolk and the Tudors: Politics and Religion in an English County 1500-1600 (Oxford: Oxford University Press, 1986), 223-224.

81 Miller, ed., 202; J. E. Neale, Essays in Elizabethan History (London: Cape, 1958), 60.

82 Patrick Collinson, Elizabethans (London: Hambledon and London, 2003), 34.

83 For examples, see Peck, "Jacobean Dilemma," 31; idem, Northampton, 24-30; MacCulloch, Suffolk, 84-104; Simon Adams, "Because I am of that Countrye \& Mynde to Plant Myself There': Robert Dudley, Earl of Leicester and the West Midlands," Midland History 20 (1995): 21-74; Cathryn Enis, "The Dudleys, Sir Christopher Hatton and the Justices of Elizabethan Warwickshire," Midland History 39 (2014): 1-35; Stephen Hollings, "Court Patronage, County Governors and the Early Stuart Parliaments," Parergon 6 (1988): 121-135; Alison D. Wall, "Points of Contact': Court Favourites and County Faction in Elizabethan England," Parergon 6 (1988): 215-226.

84 Collinson, Elizabethans, 34. 
appointment of officials to naval administration posts, it can also be understood within a broader patronage context. 85 It was important that Elizabeth's or James's efforts at building patron-client bonds benefitted the crown and resulted in loyal service and wider broadcasting of agendas, for example. This thesis will examine how both monarchs used aristocratic marital alliances as opportunities for patronage and as conduits of royal authority and ideas.

\section{Historiography}

A study of monarchical management of noble marriages-the core of this thesis-requires engagement with several distinct scholarly literatures. No other historical research fully or precisely corresponds to its study, although the works of four historians in particular have aided in its description and elucidation. These include Stone's The Crisis of the Aristocracy, 1558-1641, Brown's Noble Society in Scotland: Wealth, Family and Culture from Reformation to Revolution and "The Scottish Aristocracy, Anglicization and the Court, 1603-38," Susan Doran's Elizabeth I and Her Circle, and Paul Hammer's "Sex and the Virgin Queen: Aristocratic Concupiscence and the Court of Elizabeth I." Similar research methods to those utilised in this thesis have been employed in these earlier studies. Each has alluded to and described specific aspects of Elizabeth's or James's involvement in or response to noble and non-noble court weddings. Stone and Brown, in particular, have used statistics, tables, or a database to support their claims as this thesis does. Also of note is Kimberly Schutte's Women, Rank, and Marriage in the British Aristocracy: 1485-2000, An Open Elite? which incorporates a database and uses as its basis Stone's An Open Elite: England 1540-1880.86 However, Schutte's study emphasises noblewomen's rank identity and overall marriage patterns over more than 500 years rather than monarchical management of those marital alliances - the emphasis of this thesis - and thus it is of limited applicability to this analysis. None of these works have methodically approached the monarchs' handling of marital alliances, limited strictly to the nobility, which would expose an overall management across the entirety of Elizabeth's or James's reigns. This thesis endeavours to do just that.

85 Peck, "Jacobean Dilemma," 37.

${ }^{86}$ Kimberly Schutte, Women, Rank, and Marriage in the British Aristocracy: 1485-2000, An Open Elite? (London: Palgrave Macmillian, 2014); Lawrence Stone and Jeanne C. Fawtier Stone, An Open Elite: England 1540-1880 (Oxford: Oxford University Press, 1984). 
Published in 1965, Stone's Crisis of the Aristocracy ushered in the focussed study of England's nobility and contained discussions of and statistics on aristocratic marriage patterns in the reigns of Elizabeth I, James I, and Charles I. Most applicable to this thesis is the section subtitled, "Royal Interference." In this segment more than fifteen examples of monarchical intervention by Elizabeth or James in aristocrats' or courtiers' marriages have been briefly depicted. Stone has commented that "Elizabeth interfered frequently, but hardly ever positively." But, after 1603, James's "efforts were... entirely directed towards the encouragement of marriage."87 Stone's employment of the term "interference" connotes negativity and, indeed, the examples he describes from Elizabeth's reign are largely negative. He has mainly referenced cases where crown discontent occurred or punishment prevailed. Though Stone has claimed that Elizabeth's interventions were rarely supportive, the opposite has been mentioned by Doran and Hammer. ${ }^{88}$ This thesis, in agreement with Doran's and Hammer's view, will also demonstrate that Stone has misrepresented Elizabeth's noble-marriage management practice.

Stone did, however, passingly mention James's backing of Anglo-Scottish marriages. This topic has been more thoroughly examined by Brown in his 1993 "Scottish Aristocracy, Anglicization and the Court." 89 In his article Brown lists more than thirty cases of intermarriage between Scottish and English courtiers which occurred between 1603 and 1638, comprising James's reign of England and part of Charles I's reign. ${ }^{90}$ Most of these weddings had the backing of the respective kings and some had their direct involvement. As Brown argues, James's participation was for the purpose of bringing the kingdoms of England and Scotland closer together when an administrative union had proved impossible through Parliament. Indeed, James's special promotion of Anglo-Scottish marriages represented a large portion of his noble-marriage management practice, though not all, and is described in greater detail in chapter three.

Doran's 2015 Elizabeth I and Her Circle has also illustrated royal participation in and reaction to noble and gentry marriages. Doran has provided

\footnotetext{
87 Stone, Crisis, 605, 607.

88 Doran, Circle, 207; Paul E. J. Hammer, "Sex and the Virgin Queen: Aristocratic Concupiscence and the Court of Elizabeth I," SCJ 31 (2000): 81.

89 Stone, Crisis, 607; Keith M. Brown, "The Scottish Aristocracy, Anglicization and the Court, 1603-38," HJ 36 (1993): 569.

90 Brown, "Scottish Aristocracy," 569-573.
} 
many accounts of court marriages and revealed not only the frequency of Elizabeth's intervention, but also the weddings' importance relative to her authority. Doran's chapters on the Suffolk cousins and the women who served in her chambers have been most applicable to this thesis. The marriages of the Elizabeth's cousins, Ladies Katherine and Mary Grey, had a bearing on the succession and were, thus, consequential to her position and succession policy. Doran describes in full the queen's reactions to the Grey sisters' unions as well as her handling of the marriages of other members of the royal household. Doran's interpretations of Elizabeth's responses to unsanctioned weddings and affairs have been pertinent to this study and are discussed below in chapter five. In addition, Doran has refuted Stone's interpretation that Elizabeth was deeply jealous of female chamber staff who married. ${ }^{91}$ Instead, the queen desired that all of her courtiers' marriage negotiations were openly accomplished, fully binding, and in no way demeaning of or disrespectful to either the couple or to the queen herself and her reputation. ${ }^{92}$ Doran's assessment of illicit court weddings and relationships builds upon Hammer's in "Sex and the Virgin Queen," which appeared in 2000. Addressing the period of 1590 to 1603, Hammer, using a small test group, has detailed some of the clandestine marriages and relationships, noble and non-noble, and Elizabeth's response to them. Based on their seeming increase, Hammer has concluded that the secret affairs and weddings can serve as an indicator of Elizabeth's diminishing authority in the final decade of her reign. ${ }^{93}$ Doran has agreed with his appraisal which is further deliberated below in chapter five. ${ }^{94}$

Brown's 2004 Noble Society in Scotland covers the period of 1560 to 1637 and is similar in scope to Stone's Crisis of the Aristocracy but dedicated to the study of the Scottish elite. Of particular interest is his chapter devoted to marriage traditions and patterns. He has based his findings on a sample of over $350 \mathrm{Scottish}$ noble marriages and has highlighted James VI/I's views on marriage as written in

\footnotetext{
91 Doran, Circle, 207; Stone, Crisis, 605.

92 Doran, Circle, 207-208.

93 Hammer, "Sex and the Virgin Queen," 97. Hammer's sample includes two clandestine noble marriages (Essex-Sidney and Southampton-Vernon), five affairs involving noblemen (three of which implicated Robert Devereux, second earl of Essex), four non-noble clandestine marriages, and two non-noble affairs, all of which occurred between 1590 and 1603. Furthermore, it is possible that Essex married as early as 1587 which would eliminate his marriage and leave only one clandestine noble marriage in the sample. See ODNB, s.v. "Devereux, Frances, countess of Essex and of Clanricarde."

${ }_{94}$ Doran, Circle, 212.
} 
Basilikon Doron. ${ }^{95}$ Like Stone, Brown has included tables, statistics, and qualitative examples of monarchical involvement in specific noble weddings, noting that influence and wealth were at the heart of marriage negotiations. Other key factors for noble families' marriage arrangements, according to Brown, were "court and... national politics" and feud-ending alliances for the establishment of peace. It follows that these would also be vital concerns of James as he was counselled on or participated in imminent marriages. While Brown provides numerous examples of royal involvement in marriages, he has not analysed in depth the greater purposes or trends behind them, apart from the Anglo-Scottish union, as this thesis will do. Furthermore, Brown, referencing payments and letters to ensure weddings took place, has suggested that "in England James VI and Charles I increased royal meddling in the marriages of the nobility after Elizabeth's relatively lax approach."96 This thesis will demonstrate otherwise. Elizabeth's and James's noble-marriage management practices were, in fact, very similar. Percentage-wise, Elizabeth was slightly more frequently involved in marriages than James (Table 2.1), although the latter was undoubtedly more supportive (Table 3.1).

Discussions of Elizabethan and Jacobean involvement in noble marriages continue to be limited principally to Elizabeth's response to clandestine court weddings and relationships and James's encouragement of Anglo-Scottish intermarriage. In response, the motivation of this thesis is to look beyond these identified phenomena to illuminate Elizabeth's and James's broader treatment of marriages. This thesis benefits from a bespoke database which captures details of 380 noble marriages. Encompassing slightly different parameters than the abovementioned scholars' works, this thesis studies a wider geographical area, England and Scotland, as well as a sweeping time frame, including Elizabeth's forty-five year reign of England, James's forty-year reign of Scotland, and his twenty-twoyear reign of England. ${ }^{97}$ Furthermore, departing from Doran and Hammer, this work focuses strictly on the nobility, excluding gentry-level or non-noble courtiers. Merging Elizabeth's and James's data and practices related specifically to the

95 Brown, Noble Society, 113-136. See JPW, 38-41.

96 Brown, Noble Society, 135, 129, 130, 126.

97 James's minority ended around November 1585. See Julian Goodare and Michael Lynch, eds., The Reign of James VI

(East Linton: Tuckwell Press, 2000), 2. 
nobility promotes a thorough evaluation and reveals broader, longer-term patterns and monarchical aims.

Simultaneously, this thesis advances a new idea-noble-marriage management-while integrating various elements of Stone's, Brown's, Doran's, and Hammer's research. In the process, it views noble-marriage management as a distinctive and vital function of the monarchical office. Significantly, it takes into account the myriad opportunities that marriages offered to the monarch for advancing royal authority, communicating policies, and stabilising the kingdom, for example. Already described, James, through his involvement in the SomersetHoward marriage, seized opportunities to establish supportive associations with members of the nobility, initiate patron-client relationships, and send a clear message of his Anglo-Scottish union goal. Consequently, this thesis seeks to reframe Stone's notion of "royal interference" in marriages, converting it instead to "royal opportunity." This is because hostile intervention, though it was required in a few marriages, was infrequent. The majority of Elizabeth's and James's involvement was positive, inclusive, and pro-monarch. Building from the Somerset-Howard example, the numerous detailed analyses undertaken in the following chapters incorporate situations of royal advocacy for as well as opposition to marriages. The examples reveal the potential and real opportunities noble marriages afforded the crown. Also of prominence, this thesis investigates monarchical non-participation and the silence of the historical record on what were significant noble marital alliances.

This study re-interprets the mechanisms and manifestations of early modern royal authority by illuminating the procedure of noble-marriage management and the opportunities monarchs derived from those unions. Moreover, it sheds further light on Elizabethan and Jacobean monarch-noble relations based on data for nearly seventy consecutive years. As a result, this thesis delivers a more dynamic and comprehensive view of early modern monarchs' involvement in marriages than offered by Stone, Brown, Hammer, or Doran. The ideas and evaluations realised herein contribute to a novel interpretation of the oversight of noble marriages as an important function of the crown and reveal Elizabeth's and James's perpetual need to uphold royal authority. 
Why focus on Elizabeth and James? Practically-speaking, their consecutive reigns of England have provided almost seventy years of noble marriage data to assess in that kingdom. This sizeable amount of time has allowed for patterns of behaviour and action to surface. But of greater significance is that both monarchs employed the symbolism and rhetoric of marriage throughout their respective reigns - a fact deeply relevant to this work. They were astute to do so as marriage was a fundamental event in early modern lives. ${ }^{98}$ Its understandable imagery and expression theoretically enabled greater connection between monarch and subject. Thus, matrimonial symbolism offered the opportunity to convey crown ambitions. Because Elizabeth ascended the throne unwed, the possibility of her marriage became a focus of her reign. Her unmarried state, Danila Sokolov has noted, meant that her entire regime was centred on the "vocabulary of royal matrimony." 99 The idea of marriage pervaded not only her speeches but also the literature and art of the age. ${ }^{100}$ In early modern England's patriarchal society, once Elizabeth married, all the power with which she had been endowed in her monarchical role would theoretically be transferred to her husband, i.e., her superior. ${ }^{101}$ However, a precedent against such a transmission of power already existed in Queen Mary I's 1554 marriage to King Philip II of Spain. Their marriage treaty preserved Mary's legal rights as queen and denied her husband any regal power. Mary's authority was safeguarded and her pre-eminence in the relationship maintained.102 Still, according to contemporary William Camden, in 1559 Elizabeth, holding up her coronation ring, professed to Parliament, "Behold... the Pledge of this my Wedlock and Marriage with my Kingdom."103 Her symbolic wedding to England allowed her to create the appearance of placing her people and kingdom first. Her mythic

\footnotetext{
98 Brown, Noble Society, 114.

99 Danila Sokolov, "Nat being (to my displesure) your wife as she": The Politics and Poetics of Sovereign Marriage in the Casket Sonnets," Modern Philology 112 (2015): 458.

100 Catherine Bates, The Rhetoric of Courtship in Elizabethan Language and Literature (Cambridge: Cambridge University Press, 1992), 5-6.

101 Ann McLaren, "The Quest for a King: Gender, Marriage, and Succession in Elizabethan England," Journal of British Studies 41 (2002): 260.

102 ODNB, s.v. "Mary I."

103 William Camden, The History of the Most Renown and Victorious Princess Elizabeth, Late Queen of England, $4^{\text {th }}$ ed. (London: Printed by M. Flesher, for R. Bentley, 1688), 27. See also Mary E. Hazard, Elizabethan Silent Language (Lincoln and London: University of Nebraska Press, 2000), 113; Susan Doran, Monarchy and Matrimony: The Courtships of Elizabeth I (London: Taylor and Francis, 1995), 2 [hereafter Doran, Monarchy]; Alison Plowden, Marriage with My Kingdom: The Courtships of Elizabeth I (London and Basingstoke: Macmillan London Limited, 1977), 82.
} 
marriage established a metaphorical bond with her subjects or "children," and, in part, legitimised her autonomous rule. ${ }^{104}$ Anthony Munday's 1584 tract, A Watchwoord to England," echoed this idea: "Her Highness is the most loving Mother and Nurse of all her good Subjects, and is likewise the husband of the common weale, married to the Realm." 105 Hence, Elizabeth was the mother and the father of the realm.

In a similar fashion, visual representations of the period reiterated the notions of Elizabeth's individual authority and figurative marriage. New currency issued early in her reign featured a Tudor rose to underscore the link between Elizabeth and her father, King Henry VIII, and reinforce her singular "right to rule."106 In addition, George Gower's 1579 Plimpton Sieve portrait and Quentin Metsys's 1583 Siena Sieve portrait, for example, allegorically reflected Elizabeth's virginity or rejection of marriage. These portraits emphasised her political power over her kingdom. ${ }^{107}$ Though she never wed, Elizabeth still took full advantage of her ability to marry. In essence, her "fertility," as Anne McLaren has described it, allowed her "to remain an autonomous queen."108 Thus, Elizabeth's emblematic marriage to England allowed her to maintain her independent authority.

James also appropriated marriage imagery when he ascended the English throne, asserting that "I am the Husband, and all the whole Isle is my lawful Wife."109 He portrayed himself as "Britain," the physical embodiment of a "marriage" between England and Scotland, using matrimonial vocabulary to express his determined goal of uniting his kingdoms. ${ }^{110}$ His public orations frequently "were filled with allusions to marriage."111 James's 1604 speech to the House of Lords repeatedly referred to marriage and unification relative to the

\footnotetext{
104 Camden, History, 27; Jill M. Hall, “Elizabeth's Symbolic Marriage to England: A History of Lasting Union,” Early English Studies 1 (2008): 11; Susan Doran, "Elizabeth I: Gender, Power \& Politics." History Today 53 (2003): 33 [hereafter Doran, "Gender, Power \& Politics"].

105 Anthony Munday, A VVatch-vvoorde to Englande (London: Printed [by John Charlewood] for Thomas Hacket, 1584), Aiiir; Hazard, 113.

106 Tarnya Cooper, “Queen Elizabeth's Public Face,” History Today 53 (2003): 39.

107 Barbara Baert, "Around the Sieve. Motif, Symbol, Hermeneutic," Textile 17 (2019): 8; Deanne Williams, "Dido, Queen of England," ELH 73 (2006): 39; Doran, "Gender, Power \& Politics," 35.

108 McLaren, 268.

$109 \mathrm{JPW}, 136$.

110 Brian P. Levack, The Formation of the British State: England, Scotland, and the Union, 1603-1707 (Oxford: Clarendon Press, 1987), 186.

111 Brown, “Scottish Aristocracy,” 569. See also JPW, 38-41, 132-146, 161-164, 208-209.
} 
creation of Britain. ${ }^{112}$ Later that year, a royal proclamation declared his new title of "King of Great Britain."113 James developed new coats of arms and flags which joined English and Scottish symbols in the process of embracing the union of crowns. He envisioned one royal seal and a single coinage. ${ }^{114}$ In 1604, the unite coin was introduced to symbolise the amalgamations of his kingdoms. ${ }^{115}$ In one version, James appeared in profile on the obverse wreathed in the legend which proclaimed his new title: King James of Great Britain, France, and Ireland. ${ }^{116}$ The reverse of one type of shilling minted after 1603 went further, the legend reading QUAE DEVS CONIVNXIT NEMO SEPARET (What God hath joined together let no man put asunder); the exact words proclaimed in the Church of England marriage ritual. ${ }^{117}$ Already described, James promoted intermarriage between his English and Scottish courtiers to further the idea of Britain, to foster harmony between the kingdoms, and to promote the birth of truly "British" subjects. With each of these emblems and efforts James took advantage of the chance to remind his subjects of his desire for an Anglo-Scottish union. Just as Elizabeth and James utilised marriage rhetoric and symbolism to reinforce personal goals-autonomous rule or kingdom union-so they also exploited the prospects that aristocratic marriages offered them. Through noble-marriage management they achieved additional aims connected to their monarchies like royal supremacy, constructive monarch-noble relations, and kingdom stability.

Researching the reigns of a male and a female monarch might also signal a gender study but, this subject area has not been my focus. Certainly, there were differences between Elizabeth and James. Elizabeth was an unmarried, often deemed sexually ambiguous, English woman who referred to herself in the masculine as a prince or king. ${ }^{118}$ The "weakness and infirmity" of her female sex

112 JPW, 132-146; Robert Lawson-Peebles, "A Conjoined Commonwealth: The Implications of the Accession of James VI and I," The Yearbook of English Studies 46 (2016): 60-62; Croft, King James, 59.

113 James F. Larkin and Paul L. Hughes, eds., Stuart Royal Proclamations, vol. 1 (Oxford: Clarendon Press, 1973), 94-98. See also TNA, SP 14/7/79.

114 Sybil M. Jack, "National Identities within Britain and the Proposed Union in 1603-1607," Parergon 18 (2001): 79.

115 The Metropolitan Museum of Art, "Unite coin of James I (r. 1603-25)," accessed 3 November 2019, https://www.metmuseum.org/art/collection/search/188484.

116 "Unite coin of James I (r. 1603-25);" Royal Collection Trust, "James I, second coinage, Unite, mintmark rose," accessed 3 November 2019, https://www.rct.uk/collection/443085/james-i-second-coinage-unite-mintmark-rose; H. W. Morrieson, "The English Silver Coins of James I," The British Numismatic Journal 4 (1907): 166-168.

117 Morrieson, 169-171; Cressy, Birth, 341.

118 Annaliese Connolly and Lisa Hopkins, eds., Goddesses and Queens: The Iconography of Elizabeth I (Manchester: Manchester University Press, 2007), 1; Janel Mueller, "To My Very Good Brother the King of Scots': Elizabeth I's Correspondence with James VI and the Question of the Succession," PMLA 115 (2000): 1066; Hazard, 14. 
was often discussed at the time of her reign. ${ }^{119}$ Moreover, unlike James, she was a parsimonious queen. ${ }^{120}$ Her "rigid economy" restrained her munificence, precluding the bestowal of many financial gifts, particularly at the event of noble marriages. ${ }^{121}$ Funds were especially limited in the latter half of her reign, due to inflation and the pressures of war, but Parliament always granted subsidies when she asked-these were never endangered though they were insufficient. ${ }^{122}$ She bolstered the treasury, in part, through the granting of monopolies; a royal prerogative action questioned by the Commons but which produced much-needed funding. 123

In contrast to his cousin Elizabeth, James was a married, and, according to current assessments, homosexual or bisexual Scottish man. ${ }^{124}$ His unusual closeness to male favourites ${ }^{125}$ and his preference for fellow Scots once he became king of England were regularly debated during his tenure.126 Furthermore, as Peck, Croft, and Roger Lockyer have observed, James was abundant in his financial support of courtiers. ${ }^{127}$ On several occasions, he subsidised dowries or wedding feasts or paid for weddings entirely. ${ }^{128}$ This was because, as king, he believed he was a father to his subjects as well as a provider: "the Fathers chief joy ought to be in procuring his children's welfare, rejoicing at their weal."129 According to G. P. V. Akrigg, James linked his honour to monetary generosity, operating "on the

\footnotetext{
119 Laurence Humphrey, The Nobles, or of Nobilitye (London: By Thomas Marshe, 1563), Aiiv. See also, for example, John Knox, The First Blast of the Trumpet against the Monstrous Regiment of Women (1558; reprint, New York: Da Capo Press, 1972); John Aylmer, An Harborovve for Faithfull and Trevve Subiectes agaynst the Late Blowne Blaste, concerninge the Gouernme[n]t of VVemen (London: Printed by John Day, 1559).

120 R. W. Hoyle, "The Masters of Requests and the Small Change of Jacobean Patronage," EHR 126 (2011): 544; MacCaffrey, "Place and Patronage," 102; Stone, Crisis, 71.

121 Elton, ed., 45; Lockyer, Britain, 242.

122 Lockyer, Britain, 241-242; Elton, ed., 309; Stone, Crisis, 607.

123 Sacks, 138-139, 145; Elton, ed., 309, 311; Rosemary Sgroi, "Monopolies in Elizabethan Parliaments," The History of Parliament, accessed 23 January 2020, https://www.historyofparliamentonline.org/periods/tudors/monopolieselizabethan-parliaments.

124 Some examples include Michael B. Young, "James VI and I: Time for a Reconsideration?," Journal of British Studies 51 (2012): 540-567; Jenny Wormald, "James VI \& I," History Today 52 (2002): 33; Stone, Crisis, 607.

125 For examples, see TNA, SP 52/43/16; Calendar of the Letters and Papers Relating to the Affairs of the Borders of England and Scotland, ed. Joseph Bain, vol. 1 (Edinburgh: H. M. General Register House, 1894), 82; Frederick von Raumer, ed., History of the Sixteenth and Seventeenth Centuries, Illustrated by Original Sources, trans. H. E. Lloyd, vol. 2 (London: John Murray, 1835), 219, 234; Thomas Scott, The Belgicke Pismire (London: s.n., 1622), 10-12, 37-40; Thomas Birch and Robert Folkestone Williams, eds., The Court and Times of James the First, vol. 1 (London: Henry Colburn, 1848), 372-373; Anthony Weldon, The Court and Character of King James (1640; reprint, London: G. Smeeton, 1817), 6-7, 26-27; Young, 543-545.

126 Lodge, 1838 ed., vol. 3, 31-32n; Birch and Williams, eds., 69; Weldon, 18.

127 Peck, Court Patronage, 32; Croft, King James, 40; Roger Lockyer, “James VI/I," History Review 5 (1999): 11; Hoyle, 544.

128 See chapter three, the Huntly-Stewart, Herbert-Vere, and Hay-Denny weddings in particular.

${ }^{129}$ JPW, 65; James Doelman, King James I and the Religious Culture of England (Cambridge: D. S. Brewer, 2000), 1-2.
} 
assumption that largesse secured allegiance and affection." ${ }^{130}$ Still, his liberality caused treasury problems in Scotland prior to 1603 despite efforts to reduce debts. $^{131}$ When Elizabeth died she left behind a $£ 100,000$ debt but by 1608 the English deficit had soared to nearly $£ 600,000$; albeit James did have two aristocracies to support and three royal households to maintain-Queen Anne's, Prince Henry's, and his own.132 In the 1610 Parliament, Robert Cecil, first earl of Salisbury and lord treasurer, proposed his "Great Contract" scheme: a financial plan which sought to manage crown debts by relinquishing numerous plural prerogatives including wardship and purveyance in favour of a lump sum payment and an annual income. The Great Contract failed to gain Commons approval and, during the session, further subsidies were refused for fear James would squander them, as Andrew Thrush has noted.133 Instead, the king generated funds through the sale of titles and via impositions - taxes on trade which were protected by the royal prerogative and law but also highly criticised by the Commons. ${ }^{134}$

Despite their differences Elizabeth and James had similar educational backgrounds and experiences in youth and young adulthood. James summarised their early years well in a 1585 letter he wrote to Elizabeth: "we both have, found the favour of our God effectually assisting and preserving us against so many dangers wherewith both our persons and estates have been extremely threatened."135 Relative to governance, they shared many commonalities like state-supported Protestantism, the patronage system, and reliance on favourite courtiers and the royal prerogative, but they held other affinities as well. In their practice of kingship they both operated within similar institutions and parameters; they employed like monarchical procedures and mechanisms of power. As mentioned above, both relied on the symbolism and rhetoric of marriage as well as monarchical privileges-plural prerogatives, the royal prerogative, and the myriad

\footnotetext{
130 LKJ, 18.

131 Croft, King James, 40; Julian Goodare, "Scottish Politics in the Reign of James VI," in The Reign of James VI, ed. Julian Goodare and Michael Lynch (East Linton: Tuckwell Press, 2000), 41.

132 Smith, Stuart Parliaments, 108; J. R. Tanner, Constitutional Documents of the Reign of James I 1603-1625 (1930; reprint, Cambridge: Cambridge University Press, 1961), 355; Kenyon, ed., 47-49.

133 Eric Lindquist, "The Failure of the Great Contract," Journal of Modern History 57 (1985): 619-620; Smith, Stuart Parliaments, 55, 107; Russell, James, 167; Andrew Thrush, "The Parliament of 1604-1610," The History of Parliament, accessed 23 January 2020, http://www.historyofparliamentonline.org/volume/1604-1629/survey/parliament-16041610.

134 Peck, Court Patronage, 32-33; Smith, Stuart Parliaments, 107; Thrush, "The Parliament of 1604-1610." The 1606 Bates Case had determined that impositions were legal. See Croft, "Bate's Case," 523-539. 135 LKJ,63.
} 
benefits contained within them-for financial support and as means to initiate patron-client relationships with their respective aristocracies. Finally, each was a "parent" to his or her respective realm and each was at the apex of the hierarchical system. They were, thus, in many ways on comparable footing.

From these perspectives, Elizabeth's and James's similarities outweigh their differences. As a result, I have chosen to view the position of monarch as one which transcended surface disparities like sex, gender, or nationality. ${ }^{136}$ The office of the monarch and the functions of that position, namely noble-marriage management, lie at the centre of this thesis instead. Indeed, numerous monarchs of England and Scotland, both male and female, took part in noble marital arrangements. For example, King Richard II attended the wedding festivities of Thomas Mowbray, first duke of Norfolk, in 1384; King Edward IV oversaw the 1464/1465 marriage of Henry Stafford, second duke of Buckingham; and Henry VIII organised Arthur Plantagenet, viscount Lisle's 1511 marriage. Queen Mary I approved the 1555 marriage of Thomas Howard, fourth duke of Norfolk, and Mary Stuart, queen of Scots, was present at the 1562 marriage banquet of John Fleming, fifth Lord Fleming. ${ }^{137}$ Later, in 1636, Charles I supported the marriage of Lord Russell and Lady Anne Carr. ${ }^{138}$ The above instances and the remainder of this thesis show that both male and female monarchs participated in noble marriages, suggesting that involvement was a mechanism of monarchy, rather than related to the monarch's gender. Specific crown reactions to alliances may have been gendered but, having already demonstrated the substantial parallels between Elizabeth and James, a gendered approach to this study seems unsuitable. By assuming this non-gendered stance, I have concurred with Doran's particular assessment of Elizabeth:

gender had less impact on political life than is generally assumed... While Elizabeth had her own style of leadership, she worked within the same institutional structures and adopted the same royal conventions as earlier monarchs. 139

\footnotetext{
136 I thank Professor Elizabeth Ewan for highlighting this point.

137 ODNB, s.v. "Mowbray, Thomas, first duke of Norfolk;" ibid, s.v. "Woodville [Wydeville], Richard, first Earl Rivers;" ibid, s.v. "Plantagenet, Arthur, Viscount Lisle;" ibid, s.v. "Howard, Thomas, fourth duke of Norfolk;" ibid, s.v. "Fleming, John, fifth Lord Fleming."

138 William Knowler, ed., The Earl of Strafforde's Letters and Dispatches, vol. 2 (London: William Bowyer, 1739), 2; Stone, Crisis, 608.

139 Doran, “Gender, Power \& Politics,” 35; idem, “Did Elizabeth’s Gender Really Matter,” 33, 51-52.
} 
This thesis will establish that, at least within the realm of noble-marriage management, both monarchs acted analogously. Therefore, understanding and evaluating the practice of noble-marriage management is best achieved through a study of the monarchical office rather than through a gendered interpretation.

\section{Sources}

Elizabeth's and James's lengthy reigns, covering almost seventy years in England and forty years in Scotland, has enabled a broad historical view. ${ }^{140}$ The longue durée has aided in the establishment and elucidation of both monarchs' noble-marriage management practices. It has also meant the examination of a greater number of sources in the search for details of marriages which took place from 1558 to 1625 . Information on weddings often had to be collected from multiple sources to establish clear pictures of the unions as well as monarchical knowledge of, reaction to, and involvement in them. As a result, many different types of archives and primary sources have been consulted to illuminate the mechanisms behind monarchical management of noble marriages: Elizabeth's and James's speeches and writings, state papers and collections of personal correspondence, tracts and Privy Council records, foreign ambassador reports and patent rolls, masques and chronicles of royal progresses, parliamentary journals and sixteenth- and seventeenth-century books, plays and statutes, court cases and sermons, diaries and law commentaries. ${ }^{141}$ Likewise, the secondary sources examined have also varied in subject matter and scope, encompassing such topics as early modern marriage and family, Protestantism and Catholicism, the Elizabethan settlement, and the Scottish kirk, divine right and the law, wardship and prerogative courts, the royal prerogative and absolutism, patronage and peerage manuals. In the convergence of myriad topics and ideas it would be easy to lose sight of the original focus of monarchs and their handling of noble marriages. As a consequence, this study is not deeply immersed in any single topic; rather, topics are addressed by way of individual case studies. The case studies reveal that noble-marriage management provided many opportunities for

\footnotetext{
140 The database records details of noble marriages which took place in England from 1558 to 1625 and in Scotland from 1585, the beginning of James's personal rule, to 1625.

141 Many of the primary sources have been accessed through online databases like State Papers Online, Cecil Papers, MEMSO, EEBO, and ECCO.
} 
applying and extending royal authority and was a vital function of Elizabeth's and James's monarchies.

Some of the primary sources utilised are public—state papers, Privy Council records, patent rolls-while items like letters were personal in nature. Little information on noble marital alliances is found in official state papers. This relative paucity is, on the whole, unsurprising as the early modern monarchy hinged on personal relationships. The monarch's personal attendance at or participation in a noble wedding, though it might have indirect effects on government, has been left unchronicled in many state-related documents. Instead, much detail on marriages has been derived from letters and foreign communications like the French, Venetian, and Roman diplomatic messages. ${ }^{142}$ Similarly, the Spanish ambassadorial reports of Guzman de Silva or Guerau de Spes in the early Elizabethan period and the letters of English emissaries to Scotland prior to 1603, Robert Bowes and William Ashby, have been enlightening. ${ }^{143}$ These reports have often provided different views on planned or pending marriages as well as rumour and gossip. Additionally, the correspondence compiled in different Historical Manuscripts Commission (HMC) volumes and the Sidney Papers has related to the Elizabethan and early Stuart English court and has mentioned pending nuptials. ${ }^{144}$ The letters of John Chamberlain and Sir Ralph Winwood have covered the final years of Elizabeth's reign and James's reign of England. Each source of correspondence has been vital for uncovering details of noble alliances and monarchical reactions. ${ }^{145}$ Personal letters and ambassadorial dispatches such as these have required careful examination as they often include hearsay, speculation, and other unconfirmed information.

Overall, the sources surveyed and employed for the illustration of my arguments are also familiar to scholars of the period. Likewise, many of the marriages presented below have already been thoroughly researched by others; their details are generally known. For instance, much has already been written on

\footnotetext{
142 Bertrand de Salignac, Seigneur de La Mothe Fénélon, Correspondance Diplomatique, ed. C. P. Cooper, vols. 4, 6 (Paris and London: s.n., 1838-1840); M. Le Baron Kervyn de Lettenhove, Relations Politiques, vol. 2 (Brussels: F Hayez, 1883); CSPV, 1558-1625; CSPR, 1558-1578.

143 CSPSp, 1558-1579; CSPSc, 1584-1597.

144 Sidney Papers, 2 vols. (1559-1663).

145 Chamberlain, 2 vols. (1597-1626); Winwood, 3 vols. (1596-1614).
} 
the Hertford-Grey, Keys-Grey, Essex-Howard, Somerset-Howard marriages. ${ }^{146}$ Instead, the originality of this study rests in its novel portrayal of Elizabeth's and James's management of noble marriages. Their responses to the marital unions described below are viewed as expressions or communications of the monarchical office. Attention is focussed on what opportunities were gained or lost by the crown through involvement or lack thereof. And, all of this is backed by database statistics. Given the breadth of this study and the amount of information required, the creation of a bespoke database was essential to organise the research and facilitate its interpretation.

\section{Database}

The development of a database, tailored for the capturing of thousands of details of noble marriages, has been a multistep process requiring hundreds of hours of research and entry. It has involved, first, the identification of members of the aristocracy, men and women with titles, including female claimants, who married between 1558 and 1625. ${ }^{147}$ The database does not include proposed or planned marriages though some are mentioned in later chapters. Information gathered on titled men and women and their spouses has included essential facts like birth/death dates, title(s) held and year of accession, religious denomination, and the year the marriage occurred. Each marriage has been allotted a separate row in the database where more than thirty customised fields capture details of the couple and their union. As mentioned, research across a vast array of sources has elucidated this material. Some fields have been populated from details obtained from reference sources like G. E. Cokayne's The Complete Peerage, Sir John Balfour Paul's The Scots Peerage, and the Oxford Dictionary of National Biography. Other details have been derived from primary sources like private correspondence and ambassadors' reports.

The database has also recorded whether there was either definite or imputed monarchical involvement in the marriage, whether involvement took

\footnotetext{
146 For examples, see Hester W. Chapman, Two Tudor Portraits: Henry Howard, Earl of Surrey and Lady Katherine Grey (Boston and Toronto: Little, Brown and Company, 1960); Leanda de Lisle, The Sisters Who Would Be Queen: The Tragedy of Mary, Katherine and Lady Jane Grey (London: Harper Press, 2008); Bellany, Politics of Court Scandal; Somerset, Unnatural Murder.

147 Generally speaking this is the groom, but there were several instances where the bride held a title in her own right and these are included in the database. Despite not having titles in their own right, Ladies Katherine and Mary Grey and Lady Arbella Stuart are also included due to their claims to the throne. Any other exceptions are footnoted.
} 
place before or after the wedding, and, if applicable, the involvement strategy employed and the crown policy associated with the match. Definite noblemarriage "involvement" by a monarch has been determined from sources which confirm that the monarch participated in some way, i.e., attended the wedding or celebrations, offered financial support, i.e., paid for the wedding, provided money, or a gift. Involvement has been imputed in some cases though no comment of monarchical participation has been made in the sources. Likewise, participation has been attributed when either one or both members of the couple had kinship ties to the monarch or served in the royal household or as a high-level government official, any of which ensured contact with the monarch. Crown involvement has also been credited in cases where a monarchical privilege like a title, office, monopoly, or charter, for example, was bestowed upon a member of the couple within one year of the marriage taking place.

The final results of monarchical involvement reported throughout this thesis are those that are imputed. The appendix provides a brief listing of all imputed involvement by Elizabeth and James. Along with planned but unaccomplished marriages, dynastic or royal marriages involving acting or deposed monarchs are not included in the database. For example, absent are Elizabeth's own marriage negotiations, her proposed English suitors for Mary Stuart in 1562 and 1564, and the 1565 Scottish queen's marriage to English nobleman Henry Stewart, lord Darnley. Likewise, Mary's 1571 projected marriage to Thomas Howard, fourth duke of Norfolk, is not included. Some of these projected or actual marriages are mentioned in subsequent chapters though they are outside the specific scope of this work.

Overall, the completed database of more than 14,000 entries on 380 marriages makes possible a comprehensive study of Elizabeth's and James's management process. The database affords a clearer view of the importance of marriages in exercising royal authority, connecting monarch to noble, and providing myriad other opportunities to the crown. The data assembled enable the identification of patterns of and strategies behind the noble-marriage management of Elizabeth and James. They expose the similarities and differences between the monarchs' practices. Data evaluation also speaks to the most 
pertinent issues of each monarch's reign. More importantly, the database provides statistical backing for those patterns, strategies, and issues. None of the evaluations or contentions contained herein would have been possible without a database, using other research methods. That said, as Stone has remarked, "statistics make a dry and unpalatable diet unless washed down with the wine of human personality." 148 Consequently, the figures and trends from the database are contextualised within descriptive examples in the following chapters. The combination of two methodologies provides a more far-reaching, effective assessment of noble-marriage management as a function of the monarchical office.

Database analysis has fundamentally shaped the structure of this thesis. The following chapters two through five comprise both database evaluations and case studies, revealing the monarchs' changing approaches to marriages relative to contemporary events and need to connect with the aristocracy. Chapter two highlights the religious and political backgrounds and theories of the early modern era which upheld monarchical authority and, thus, enabled effective noblemarriage management. It provides tables and statistics on the frequency of noble marriages from 1558 to 1625 and how often Elizabeth and James became involved in weddings. It also expounds upon important crown policies of the period, specifically those which connected to religion, succession, and Anglo-Scottish union. In the process, chapter two shows the regular correlation between noblemarriage involvement and crown interests.

Drawn from database evaluations, the three main noble-marriage management strategies-support, non-participation, and opposition-form the bases of chapters three through five. The focus of chapter three is the monarch's show of support for marriages through the use of patronage. The monarch's personal attendance at a wedding ceremony or subsequent celebrations signalled the initiation of a patron-client relationship with the newlyweds. As mentioned in the introduction, this thesis contends that the duration of that patron-client bond reveals the effectiveness of the monarch's participation. Chapter three provides figures on the duration of those bonds as well as a reinterpretation of Stone's and Brown's assessments of Elizabeth's approach in aristocratic unions. It also

148 Stone, Crisis, 4. 
highlights the role of the royal prerogative in the monarchs' supportive involvement, particularly as it related to religious and union policies.

Chapter four discusses monarchical non-participation in marriages. What is remarkable about these weddings is the obvious lack of crown involvement when it would otherwise be expected due to kinship or close association between the monarch and the noble couple. This chapter argues that non-participation signified an uncertain, anticipatory attitude, passive displeasure, or tacit isolation from royal favour. It also connects non-participation with the "silence" of the royal prerogative and shows Elizabeth and James as hesitant over marriages, especially those which involved Catholic nobility.

Chapter five examines monarchical opposition to marriages which included declaration of disapproval and punishment of transgressors. This chapter is also backed by tabulated data. Punitive measures generally followed weddings which took place contrary to the monarch's command or without his or her knowledge. Judgments were sometimes exacted through prerogative courts convened by the monarch, under his or her influence, and punishments were bolstered and elongated by the royal prerogative. Elizabeth and James most often used this strategy in cases of clandestine marriages or marriages which touched on the succession. Chapter five reassesses Hammer's and Doran's impressions on Elizabeth's level of authority in the 1590s. Moreover, it upholds other historians' views on Elizabeth's succession plans and James's promotion of Anglo-Scottish marriages.

\section{Conclusion}

The actuality and significance of concerted monarchical handling of noble marriages has heretofore received little attention. Therefore, the purpose of this thesis is to assert that noble-marriage management was an important function of the early modern monarchy. This is because the supervision and treatment of marriages provided valuable opportunities to Elizabeth and James to strengthen monarch-noble relations, to forward crown programmes in religion, succession, and Anglo-Scottish union and to reinforce the hierarchical nature of royal authority. This study illuminates the strategies Elizabeth or James developed to deal effectually with unions, whether by supporting, not participating in, or 
opposing them. For example, the monarch's presence at a wedding ceremony forged patron-client links for the benefit of both parties. This important monarchnoble bond established at the event of a noble marriage has not been emphasised by historians.

It might be argued that Elizabeth's or James's "gift" of attendance at a wedding simply followed traditional gift-giving practices of the period and could be seen as unremarkable or impossible to reciprocate. But, this thesis proposes that while marriages were liminal moments in couples' lives which merited customary gifts, the royal presence at a wedding ceremony indicated both approval and a promise of support, akin to the royal healing touch ceremony. This was in exchange for allegiance and compliance with the prevailing hierarchy dominated by the monarch.

Patron-client ties established at weddings through monarchs' encouraging involvement were frequently nurtured over time with additional patronage sourced from royal privileges - the tools by which Elizabeth and James assembled their supportive patronage networks. This thesis argues that the duration of monarch-noble patron-client relationships was a key component in determining the overall effectiveness of sponsoring marriages. Moreover, trust, loyalty, and reciprocity, the foundations of positive monarch-noble relations and of effective patronage, became increasingly significant as royal privileges began to be questioned in the House of Commons. The Commons's censure consequently boosted the monarch's need for privileges in order to secure noble backing.

This thesis is one of only a few studies to concentrate on the role monarchs played in noble marriages. It is also among a small number of works which have used database analysis and case studies to evaluate marriages that took place among the aristocracy. In the following pages, marriages are described within the context of crown-derived benefits-in loco parentis rights, plural prerogatives, the royal prerogative, distribution of patronage, and the convention of prerogative courts-which directed involvement. Further light is shed on monarch-noble relations by exploring Elizabeth's or James's attitudes and reactions to aristocratic marital alliances. This illumination provides a unique perspective which complements current understanding of monarchical and noble power in the 
Elizabethan and Jacobean periods. Through database findings and qualitative examples, noble-marriage management is shown as a vital apparatus of the early modern monarchy which upheld royal supremacy. Thus, it is a practice worthy of greater recognition and more thorough examination. 


\section{Chapter 2}

\section{"By me princes rule, and nobles": the power behind noble-marriage management ${ }^{1}$}

In late 1580s Scotland, Alexander Lindsay, later first lord Spynie, became King James VI's vice-chamberlain and favourite-the king's "only minion... his nightly bedfellow."2 Perhaps because his own wedding to Anne of Denmark was imminent, James decided to arrange Lindsay's marriage to Lady Jean Lyon, daughter of John Lyon, eighth lord Glamis, and widow of the earl of Angus. Acting in loco parentis, James had the privilege of assisting in and assenting to the selection of Lindsay's future wife. Likewise, the plural prerogative of widows' marriages secured James's right to approve the widowed Lady Jean's remarriage and prospective husband. ${ }^{3}$ He took full advantage of the authority granted him through these entitlements.

From the king's perspective, the Lindsay-Lyon alliance was important, not simply because his favourite would be favourably wedded to a countess but also due to an event that had occurred more than a decade prior, in 1578. In that year Glamis, Lady Jean's father, had been killed when some of his retainers became entangled with those of the eleventh earl of Crawford, Lindsay's brother. The event of Glamis's death had been only the latest clash in a two-hundred-year-old feud between the Lindsay and Lyon families. ${ }^{4}$ It seems certain that the king purposefully organised the Lindsay-Lyon union to procure a wealthy widow for his favourite companion, end family feuding, and establish peace. He accomplished this by initiating a patron-client relationship with the couple on account of their marriage, one which would be mutually beneficial: James would have a greater level of stability within his kingdom while Lindsay and Lady Jean would receive

\footnotetext{
1 Prov. 8:16 KJV.

2 BL, Cotton MSS, Caligula D/I fol. 336; TNA, SP 52/44/43; Amy L. Juhala, "The Household and Court of James VI of Scotland, 1567-1603" (Ph.D. diss., University of Edinburgh, 2000), 310. As the fourth son of David Lindsay, tenth earl of Crawford, Lindsay was neither a peer nor an heir to a peerage at the time of his marriage. However, because James promised his elevation prior to his marriage taking place, the Lindsay-Lyon marriage has been included in the database. ${ }^{3} R M, 337$.

4 TNA, SP 52/27/32. See also A. W. C. L. Crawford, Lord Lindsay, Lives of the Lindsays, vol. 1 (Wigan: C. S. Simms, 1840), 174; ODNB, s.v. "Lyon, Sir John, lord of Glamis."
} 
crown benefits. The king's patron-client bond also recognised the new lateral connection established between two influential noble families, the Crawfords and the Lyons, drawing their allegiances from each other to the crown.

Extant letters reveal that Lady Jean had misgivings about the proposed marriage with Lindsay. She may have believed such a match would be a mésalliance, considering the difference in rank. James wrote to Lady Jean at least twice offering his reassurance and approval of the match. Hoping to secure Lady Jean for Lindsay, James praised his favourite, "whose blood, whose affection, and whose credit with me, I hope, be nothing inferior to any that can suit you." As an enticement James pledged to Lady Jean that Lindsay would receive a title and lands commensurate to her own status: "I will advance him to such degree as that place merited." ${ }^{5}$ Clearly, James felt this should be enough to turn any indecision into a positive response. But, if not, James ended the letter in a firm, unyielding manner:

Now, since I am so constant in this matter and his affection so lasting, I look the constancy shall not inlayke [be lacking] at the third hand [Lady Jean's], which otherwise (as God forbid) this matter, being so publicly broken forth as it is, would turn to my scorn, his scathe, and your small honour.

After this it appeared that Lady Jean still doubted the scheme, her hesitancy prompting another letter from the king:

According to my promise, I am resolute to advance this man of mine [Lindsay], whom for I have now so long dealt with you, to the rank that ye was last joined withal, that ye may be matched with that rank which ye presently possess and this will I do, without fail, at the time of the solemnization of my marriage as the properest time for such an action and for providing him of a living correspondent to that estate.

Made manifest in the letters were James's power and desire to compel the marriage. He also emphasised the importance of hierarchy and rank: between the couple themselves and between Lady Jean and her king. Lady Jean, submitting to James, acquiesced to marriage with the yet-to-be elevated Lindsay and the couple were married in May $1590 .{ }^{6}$ Lindsay was elevated to the Scottish peerage in November 1590 as first lord Spynie.

${ }^{5}$ LKJ, 92-93; Crawford, 174.

${ }^{6}$ LKJ, 92-94. A proxy marriage between King James and Anne of Denmark occurred on 20 August 1589. 
The James-Lindsay-Lyon patron-client relationship was, however, shortlived.7 After his marriage Lindsay attended Parliament and Privy Council meetings and became a favourite of Queen Anne. But in 1591 his associates at court, Huntly and Francis Stewart, first earl of Bothwell, fell into disfavour and the post of treasurer of the realm, an appointment it was rumoured Lindsay would fill, never materialised. He was then accused of treason for harbouring James's enemy, Bothwell, in 1592; Lady Jean had a kinship tie to Bothwell. ${ }^{8}$ He subsequently lost his place in the royal bedchamber and the king's support. Why did the patronclient relationship fail? Was it perhaps because the king placed the stability of his kingdom, achieved on a small-scale through the Lindsay-Lyon peace-making marriage, above his personal promises to the couple? The king had pledged to Lady Jean that Lindsay would be raised to her own status; that he would be made an earl on the occasion of his own marriage to Anne in late 1589. Instead, Lindsay was made a lord, a rank two levels below that of an earl, and the ennoblement did not occur until late 1590, at least a year after James had sworn to do so in his letters. ${ }^{9}$ Furthermore, Lindsay failed to attain the treasurer position. Lindsay's disloyalty may not have stemmed directly from the king's delayed and reduced gift of elevation or his lack of promotion to treasurer. But these broken royal assurances or understandings may have been contributing factors as might Lady Jean's family connection to Bothwell. Nevertheless, the Spynies enjoyed a long and fruitful marriage-their bond between each other was apparently successful at least-though the feud between the Lindsays and Lyons continued. Royal patronage remained suspended for two years when, in 1594, Lindsay reconciled with James and took up administrative and household duties once more, but he never again achieved "favourite" status with the king. ${ }^{10}$ Later, James may have drawn from his experience arranging the misaligned Lindsay-Lyon marriage when he wrote Basilikon Doron. In it he carefully advised his son to choose a wife of a similar position to his own, "her rank and other qualities being agreeable to your

\footnotetext{
${ }^{7}$ CP, Vol. 169/9.

8 ODNB, s.v. "Lindsay, Alexander, first Lord Spynie." Lady Jean had been mother-in-law to Bothwell's wife, Lady Margaret Douglas, daughter of David, seventh earl of Angus.

${ }^{9}$ George Edward Cokayne, ed., The Complete Peerage of England, Scotland, Ireland, Great Britain and the United Kingdom Extant, Extinct, or Dormant, new ed., rev. Vicary Gibbs et al., vol. 7 (1929; reprint, Gloucester: Alan Sutton Publishing Limited, 1984), 206.

10 ODNB, s.v. "Lindsay, Alexander, first Lord Spynie."
} 
estate."11 James's failure to manage well his patron-client bond with the Spynies reflected the instability of early modern Scotland's monarchy and patronage and the role the nobility could play in stabilising the prevailing hierarchical system.

The Lindsay-Lyon marriage reveals several elements of the early modern monarchy: the sometimes-tenuous connections between monarch and nobility, the importance of harmony among peers of the realm, and the impact of social hierarchy. By intervening in the marriage James exercised several critical responsibilities of the monarchical office which managed these elements. These included preservation of authority and hierarchy through the plural prerogative of widows' marriages and in loco parentis right; the promotion of kingdom stability through personal organisation of and support for a peace-making noble marriage; and the extension of patronage for the establishment of what would ideally become a long-term patron-client relationship. The multiple facets of rule implemented through one single noble marriage underlined how important these alliances were to the monarchy as well as the necessity of managing them carefully.

Echoing the elements of authority and hierarchy in the Lindsay-Lyon marriage, this chapter outlines the structure of monarchy in the early modern age following its religiopolitical and legal backgrounds. It simultaneously reveals statistics on Elizabeth's and James's noble-marriage oversight and involvement. As it explores ancient and medieval theories behind monarchical dominance, it also highlights privileges of the office, like prerogatives, which had a bearing on monarch-noble relations and noble-marriage management. Employing database analysis, this chapter gauges the frequency of noble marriages and the monarchs' involvement in them. In addition, it interprets royal agendas for religion, succession, and Anglo-Scottish union in relation to aristocratic marital alliances while using the database to show links between weddings and policies. As such, it elucidates how the monarch supervised and handled these alliances to reinforce royal authority and agendas-a topic which has heretofore received little attention.

$11 \mathrm{JPW}, 40,41$. 


\section{Religiopolitical and legal backgrounds}

As in the procession before a great king the lesser ranks go first, and then in succession the greater and after them the yet more majestic... and after all these the great king himself is suddenly revealed, and the people pray and prostrate themselves before him. ${ }^{12}$

The above third-century depiction of a royal procession articulated the notion of the chain of being, a systematic ranking of individuals from those of the lowest standing up to the king who inhabited the pinnacle of the terrestrial hierarchy; a resonant motif in the Lindsay-Lyon noble marriage. Later, as ancient ideas became appropriated by the Church which sought to legitimise its rule, this theory became expressed in Christian terms. ${ }^{13}$ The result was that the chain of being or succession of life was "a connection of parts, from the Supreme God down to the last dregs of things, mutually linked together and without a break." 14 This updated, "Christianised" version of the chain of being was likely read and studied by medieval and Renaissance thinkers like Aquinas and Dante. ${ }^{15}$ Relevant to this dissertation is that the Christianised chain of being idea and various biblical texts supported the hierarchical nature of early modern English and Scottish society and the political theory of the divine right of kings, itself a basis of Elizabethan and Jacobean rule. ${ }^{16}$

The theory of the divine right of kings encompassed multiple ideas, namely that the monarch was "divinely ordained... accountable to God alone," possessed

\footnotetext{
12 Plotinus, Enneads, trans., A. H. Armstrong, vol. 5 (Cambridge: Harvard University Press, 1984), 155, 163-165. Combining ideas from Plato and Aristotle, Plotinus outlined the concept of a chain of being in his Enneads. His idea began first with the "One... the most perfect, the first Good", and it was from the One that everything emanated. From the One also came "Intellect" or truth which beings possessed to varying degrees. Plotinus described this chain of the various levels of Intellect within beings from the lowest orders to the king in the above quotation. See ibid, vol. 5, 138$139,143,153,159$.

13 Ernst H. Kantorowicz, The King's Two Bodies: A Study in Medieval Political Theology (1957; reprint, with a preface by William Chester Jordan, Princeton: Princeton University Press, 1997), 19. Macrobius expressed the chain of being in Christian terms in the fifth century. See Ambrosius Aurelius Theodosius Macrobius, Commentary on the Dream of Scipio, trans. William Harris Stahl (New York: Columbia University Press, 1990).

14 Macrobius, 145; Arthur 0. Lovejoy, The Great Chain of Being: A Study of the History of an Idea (1936; reprint, Cambridge: Harvard University Press, 1964), 63. See also Viroli, 17. Viroli notes that Macrobius's Commentary helped "keep alive another no less important tenet... namely the notion that good rulers... deserve a quasi-divine status."

15 E. M. W. Tillyard, The Elizabethan World Picture (1943; reprint, London: Pimlico, 1998), 49. Renaissance scholars were probably also familiar with Denys the Areopagite's work On the Heavenly Hierarchy which detailed the hierarchical arrangement of the angels.

16 John Neville Figgis, The Divine Right of Kings, 2nd ed. (Cambridge: Cambridge University Press, 1914), 7-8. Biblical passages from which the divine right of kings theory drew support included 1 Sam. 7:10-18; Ps. 51:4, 82:6; Prov. 8:15; Dan. 4; John 19:11; Rom. 13:1-7; and 1 Pet. 2:13-17. See also Glenn Burgess, "The Divine Right of Kings Reconsidered," EHR 107 (1992): 837-838; Conrad Russell, "Divine Rights in the Early Seventeenth Century," in Public Duty and Private Conscience in Seventeenth Century England, ed. John Morrill, Paul Slack, and Daniel Woolf (Oxford: Oxford University Press, 1993), 101-120.
} 
hereditary rights that could not be overturned, and enjoyed powers that had no lawful boundaries. ${ }^{17}$ Divine right of kings was analogous to the Catholic Church's notion that the pope was God's representative on earth. Equally, Elizabeth and James, as monarchs, were divine agents, with Ernst Kantorowicz observing that "The taking over of theological notions for defining the state-had been going on for centuries."18 Elizabeth undoubtedly viewed herself as a representative of God when she wrote, "we can be content, in imitation of God Almighty... Whose minister we are here on earth."19 Meanwhile James said, "The state of monarchy is the most supreme thing upon earth: for kings are not only God's Lieutenants upon earth, and sit upon God's throne, but even by God himself they are called Gods." 20 Divine right provided a religious and political framework of monarchical authority; established that the king's power was obtained from God, not from the people; and firmly vested that God-ordained power into the single person of the king or queen. $^{21}$ When power and authority centred on a single person it created a personalised monarchy. The personal monarchy hinged upon the individual character of the king or queen; his or her temperament and talents indelibly shaping the reign.

In a personal monarchy the king or queen was the foundation of the kingdom, existing as both the physical and symbolic head of the state. Developed from the similar religious idea that Jesus was the literal and figurative head of the Christian church, the "King's Two Bodies" theory comprised the monarch's "body natural" (the mortal being) and "body politic" (the representation of the state). ${ }^{22}$ These two bodies were indissolubly joined within the physical person of the monarch:

For the King has in him two Bodies... His Body natural is a Body mortal...But his Body politic is a Body that cannot be seen or handled, consisting of Policy and Government, and constituted for the Direction of the People, and the Management of the public weal. ${ }^{23}$

\footnotetext{
17 Figgis, 5-8.

18 Kantorowicz, King's Two Bodies, 19. See also Viroli, 63; Plowden, Commentaries, vol. 1, 213-214.

${ }^{19} L Q E, 256$.

$20 \mathrm{JPW}, 181$.

21 Ibid, 143; Burgess, 841.

22 Kantorowicz, King's Two Bodies, 15-16, 7-9. See also Jenny Wormald, Lords and Men in Scotland: Bonds of Manrent, 1442-1603 (Edinburgh: John Donald Publishers Ltd, 1985), 38.

23 Plowden, Commentaries, vol. 1, 213.
} 
The Rainbow Portrait of Elizabeth, completed c. 1600 to 1603, visually depicts the King's Two Bodies theory. According to Daniel Fischlin, the painting reveals a youthful queen who supernaturally defies the aging process with her divine body natural and, at the same time, embodies the timeless majesty of monarchy, the body politic. ${ }^{24}$ Indeed, the King's Two Bodies theory gave the monarch a mystic quality, one seen and unseen, which suggested the holiness implied by divine right. It also confirmed the monarch's pre-eminence in government and overarching duty to the public. Additionally, the King's Two Bodies theory gave Elizabeth the ability to claim her "marriage" to England. Jill Hall has suggested that "while she refused marriage in her body natural, her rhetorical marriage to England enacted a marriage in the monarch's body politic."25 Similarly, upon his accession to the English throne, James became the "husband" to his united kingdoms."26

The King's Two Bodies theory revealed another vital aspect of royal power: prerogative. The actions of the body natural came under the jurisdiction of the body politic since it was the prevailing of the two. The "body natural... is not void of prerogative... the body natural and of the things possessed in that capacity... partake of the effects of the body politic." 27 Prerogative, an important element of monarchy, was based on the dual ancient and, later, papal powers postestas ordinate (ordinary power) and potestas absoluta (absolute or plenitude of power). ${ }^{28}$ Appropriated and reinterpreted for use by early modern secular states, potestas ordinate and potestas absoluta were in England and Scotland analogous to plural prerogatives and the royal prerogative, respectively. ${ }^{29}$ The monarch's exclusive privileges, whether plural prerogatives or the royal prerogative, recognised the king's or queen's supremacy and "that especial power, pre-

\footnotetext{
24 Daniel Fischlin, "Political Allegory, Absolutist Ideology, and the 'Rainbow Portrait' of Queen Elizabeth I," Renaissance Quarterly 50 (1997): 179.

25 Hall, 3.

$26 \mathrm{JPW}, 136$.

27 Plowden, Commentaries, vol. 1, 238.

${ }^{28}$ K. Pennington, "Law, Legislative Authority, and Theories of Government, 1150-1300," in The Cambridge History of Medieval Political Thought, c.350-c.1450, ed. J. H. Burns (Cambridge: Cambridge University Press, 1988), 435-436; J. P. Canning, "Law, Sovereignty and Corporation Theory, 1300-1450," in The Cambridge History of Medieval Political Thought, c.350-c.1450, ed. J. H. Burns (Cambridge: Cambridge University Press, 1988), 455-456. See also Jane Black, Absolutism in Renaissance Milan: Plenitude of Power under the Visconti and Sforza 1329-1535 (Oxford: Oxford University Press, 2009), 12.

29 Julian Goodare, The Government of Scotland 1560-1625 (Oxford: Oxford University Press, 2004), 91.
} 
eminence, or privilege that the King hath in any kind, over and above other persons," maintaining their position at the top of the hierarchy. ${ }^{30}$

What were the powers or rights secured within plural prerogatives and the royal prerogative? How did Elizabeth and James use them to their benefit in the supervision of and intervention in noble marital alliances? Some historians refer to the two prerogatives collectively as the royal prerogative, which is correct in the sense that the crown alone wielded both types. ${ }^{31}$ However, combining plural prerogatives and the royal prerogative is confusing when they provoked differing opinions due to their relationship with common and statutory laws and when each had a distinctive origin and situational application. Separating them and defining their nature and context individually, aids in understanding the monarch's use of prerogatives, the relationship between prerogatives and law, and, in terms of this thesis, the bearing they had on noble-marriage management.

\section{Plural prerogatives}

Originating in ancient times, plural prerogatives had, by the Middle Ages, developed into the feudal rights or special advantages kings had over their tenants-in-chief, the nobility: the major landholders who were bound to the king. ${ }^{32}$ Similar to the chain of being, the feudal system of the medieval period was hierarchical in that the monarch was the leading landholder, at the top of a vertical network or pyramid of noble tenants bound to him. The king's feudal rights were many. In England they were listed in Magna Carta and they also appeared in the fourteenth-century document De Prerogativa Regis. ${ }^{33}$ Among the numerous English monarchical privileges confirmed in De Prerogativa Regis were advowsons, dowers, and knights' fees on land grants; escheat of bishops' tenants; confiscation of aliens' and felons' goods and lands; and goods recovered from shipwrecks.

\footnotetext{
30 John Cowell, The Interpreter: or Booke Containing the Signification of Words (Cambridge: John Legate, 1607), 393-397. 31 Goodare, Government, 91. Goodare differentiates between the two types of prerogatives. See also Black, 12; Canning, 455-456; Elton, ed., 17-18; Lockyer, Britain, 238, 277. Elton refers to plural prerogatives and the royal prerogative collectively. Though Lockyer is not specific, he is clearly referring to the royal prerogative instead of plural prerogatives when discussing Elizabeth. He does, however, separate the two prerogatives into ordinary and absolute when discussing James.

32 See J. Hurstfield, “The Revival of Feudalism in Early Tudor England," History 37 (1952): 131-145.

33 SR, vol. 1, 5-13, 226-227; RPS, 1367/9/4. King Edward I also signed a version of the document in 1297. See SR, vol. 1 , 114-119. See also William Staunford, An Exposicion of the Kinges Prerogative (London: Richard Tottel, 1567); Thomas Smith, De Republica Anglorum: A Discourse on the Commonwealth of England, ed. Mary Dewar (1583; reprint, Cambridge and New York: Cambridge University Press, 1982), 85-88; Nicholas Fuller, The Argument of Nicholas Fuller of Grayes Inne Esquire (London: Printed for V. Vavasour, 1641); Plowden, Commentaries, vol. 1, 223-253; Carlson, 28; Elton, ed., 19n.
} 
Similar plural prerogatives were outlined in various Scottish statutes. ${ }^{34}$ But most applicable to this thesis are plural prerogatives of wardship, marriages of wards, and marriages of widows of the monarch's tenants-in-chief.

The system of wardship gave the monarch the right to claim temporary ownership of an underage heir or heiress's lands upon the death of his or her father and to approve his or her marriage. ${ }^{35}$ Thus, it was a method used by Elizabeth and James to influence noble marital alliances. The purpose of wardship was to ensure that wards would be raised to be loyal to the crown and that their marriages would be favourable to and sanctioned by the monarch. ${ }^{36}$ The nobility, in particular, were greatly affected by the system of wardship with few families escaping its grasp due to high death rates. Wardships, because they were commodities, generated revenue for the crown: they were "valuable proprietary rights... chattels which could be bought or sold."37 In fact, as Joel Hurstfield has described, the system itself supported a "network of patronage, which was of immense importance in the finance and politics of the time." 38 For most buyers, a "primary objective" of assuming a wardship was the benefit of being able to influence the ward's marriage or to sell it. ${ }^{39}$ Each option would generate revenue either through amalgamation of resources via a marriage or via a sale. Some noble wardships were retained by the crown due to their high monetary value with the Master of the Court of Wards acting as guardian, representing the monarch. ${ }^{40}$

In Crisis of the Aristocracy, Stone briefly described multiple cases of wards' marriages, mainly highlighting their negative impact upon the individuals involved and the frequent abuses which arose due to the "notorious" system. ${ }^{41}$ Hurstfield has examined more fully the effects of wardship, wards' marriages, and widows' marriages upon men and women, demonstrating that they acted as a fundsgenerating system for the crown, one which turned minor heirs, their lands and

\footnotetext{
34 For examples see $R M, 1,6,61,68-70,71-74,337-338,354,356-357,363-364$.

35 SR, vol. 1, 226-227. Heirs who were aged 21 or more at the time of their father's death had to pay a fine, known as a relief, to obtain their land. When underage heirs attained their majority they had to pay a fee, known as a livery, to the crown to obtain full ownership of their lands.

36 Hurstfield, Queen's Wards, 331.

37 W. S. Holdsworth, A History of English Law, 3rd ed., vol. 3 (London: Methuen \& Co. Ltd, 1923), 63-64; Hurstfield, Queen's Wards, 5. Nevertheless, a duty of responsibility accompanied wardship.

38 Hurstfield, Queen's Wards, 240.

39 Ibid, 137-138, 143, 145; Elton, England under the Tudors, 51.

${ }^{40}$ Hurstfield, Queen's Wards, 145, 250; Stone, Crisis, 602. Henry VIII established the Court of Wards and Liveries to manage the wardship system. It was abolished under Charles II.

41 Stone, Crisis, 603.
} 
marriages, into saleable objects. ${ }^{42}$ Moreover, Eric Carlson and Olwen Hufton, for example, have commented on the crown's or guardian's requisite approval for wards' marriages, thus limiting the choice of partners. ${ }^{43}$ More recently, Daphne Pearson's research has detailed the problems which arose from wardship and the long-term, adverse financial consequences which often accompanied it. ${ }^{44}$ Though a widely disliked practice, wardship endured through James's reign, perpetuating the filling of royal coffers and the monarch's ability to intervene in noble marriages. ${ }^{45}$

In addition to wardship, plural prerogatives also included the monarch's right to approve the marriages of the widows of their tenants-in-chief. According to De Prerogativa Regis, "Widows... shall swear that they shall not marry themselves without the King's Licence." 46 In Scotland a similar requirement was forced upon widows of the king's tenants-in-chief: "No widow should be compelled to marry, if she please to live without any husband; but she should make security that she shall not marry without the King's consent." 47 This monarchical right, like wards' marriages, ensured that widows would not become wedded "unto the king's enemy, and thereby the strength of the crown enfeebled." 48 But, by Elizabeth's reign, as Hurstfield, Carson, and Harris have observed, most women purchased a license to remarry instead of seeking crown approval; marrying without one might result in a substantial fine. ${ }^{49}$ Conversely, in Scotland the plural prerogative of widows' marriages continued to be used in the $1590 \mathrm{~s}$ as the Lindsay-Lyon marriage has revealed. On the whole, however, widows' marriages produced "negligible" income for the English crown when compared with wardships and wards' marriages. ${ }^{50}$ Nevertheless, according to the database, wards' and widows' marriages accounted for at least $20 \%$ of all the noble marriages that took place in the Elizabethan and Jacobean periods. This reflects

\footnotetext{
42 See Hurstfield, Queen's Wards, passim; idem, "Revival of Feudalism;" idem, "Lord Burghley as Master of the Court of Wards, 1561-98," TRHS31 (1949): 95-114.

43 Carlson, 28-29; Hufton, 58.

44 Daphne Pearson, Edward de Vere (1550-1604): The Crisis and Consequences of Wardship (Aldershot: Ashgate, 2005).

45 H. E. Bell, An Introduction to the History and Records of the Court of Wards \& Liveries (Cambridge: Cambridge University Press, 1953), 133; Kenyon, ed., 46-47, 49; Hurstfield, Queen's Wards, 315-316.

$46 S R$, vol. 1,226

${ }^{47} R M, 337$.

48 Staunford, fol. 16r.

${ }^{49}$ Hurstfield, Queen's Wards, 148; Carlson, 26-27; Barbara J. Harris, English Aristocratic Women, 1450-1550: Marriage and Family, Property and Careers (Oxford: Oxford University Press, 2002), 161.

${ }^{50}$ Hurstfield, Queen's Wards, 148.
} 
the reach of plural prerogatives and exposes the crown's ability to direct these types of marital alliances. ${ }^{51}$

As in Europe, English and Scottish monarchs' plural prerogatives were entirely subordinate to law. ${ }^{52}$ Plural prerogatives, due to their long-term use and precedence were well-established within common law: the body of laws originally derived from customs which were accepted and upheld by the courts, and thereby created judicial precedents. ${ }^{53}$ England's judicial system was based on common law and elements of common law existed in Scotland from the thirteenth century. ${ }^{54}$ But plural prerogatives were also confirmed in statutory law or statutes: those laws that evolved from Parliamentary discussion and were written down and approved by the monarch in England or the three estates in Scotland. ${ }^{55}$ That English and Scottish Parliaments sanctioned both monarchs' possession and use of the plural prerogatives reflected an acceptance that they were perquisites of the office engrained through precedence and, later, formally recognised through statutes. $^{56}$ But the monarch-statute relationship was complicated. As English judge Anthony Brown explained, "the king is not generally bound by all statutes in general words, unless he is specially named." Despite a general exemption from statutory laws, the monarch's actions were still limited according to Judge Brown: "the king cannot do any wrong, nor will his [plural] prerogative be any warrant to him to do an injury to another.... It is a difficult argument to prove that a statute, which restrains men generally from doing wrong, leaves the king at liberty to do wrong." 57 Thus, Brown determined that the monarch's plural prerogatives, though secured within common and statutory laws, could be limited, if necessary.

\footnotetext{
51 Because not all noble wardships were recorded by the Court of Wards and Liveries, it is difficult to estimate exactly how many wards' marriages took place in the Elizabethan and Jacobean periods. My estimate is derived from ODNB and Cokayne, ed., The Complete Peerage entries which indicate that the noble heir's or heiress's father died before he or she had attained majority.

52 Black, 12.

${ }^{53}$ A Dictionary of Law, ed. Jonathan Law, 9th ed. (Oxford: Oxford University Press, 2018), s.v. "common law."

54 Ibid. Regarding common law in Scotland, see RPS, 1318/4; Alice Taylor, The Shape of the State in Medieval Scotland, 1124-1290 (Oxford: Oxford University Press, 2016), 16, 19; Hector L. MacQueen, Common Law and Feudal Society in Medieval Scotland (Edinburgh: Edinburgh University Press, 1993), 2-3.

55 For plural prerogatives in England see $S R$, vol. 1, 3, 15, 17, 20-21, 23, 32, 226-227; idem, vol. 4, 463, 482, 520-521, 624 For plural prerogatives in Scotland see RPS, 1567/12/104. See also Taylor, 369, 379. While Taylor's focus is twelfthand thirteenth-century Scotland, the plural prerogative of wardship was already in place by that time and it continued into James's reign. See also George Powell M'Neill, ed., Exchequer Rolls of Scotland, 1580-1588 (Edinburgh: H. M. General Register House, 1901), 580.

56 Goodare, Government, 91; Taylor, 369, 379.

57 Plowden, Commentaries, vol. 1, 236, 239-240, 248.
} 
Another remit of the monarchical office was the in loco parentis duty. While not a plural prerogative, the in loco parentis responsibility permitted noblemarriage intercession as in wards' marriages and legitimised crown involvement. Monarchs possessed a patriarchal-type authority when acting in loco parentis for younger, unmarried or widowed royal household staff in their service. In the early modern period fathers had authority over their wives and children and, similarly, the monarch had authority over his or her "family" of unmarried domestic servants. ${ }^{58}$ James mentioned this specific role in Basilikon Doron, writing "Honour also them that are in loco Parentum unto you... be thankful unto them and reward them, which is your duty and honour."59 As a guardian it became the monarch's responsibility in place of a parent to find suitable mates for any unwed or widowed household members. ${ }^{60}$ Monarchs, thus, assumed the lead role in discussing and moving a marriage forward, ensuring that it was appropriate and advantageous, that the bride and groom were suitably matched, no impediments existed, settlements were fair, and none were coerced. Elizabeth and James regularly acted in loco parentis and much of their noble-marriage involvement stemmed from royal household matches.

\section{The royal prerogative}

Unlike plural prerogatives, the royal prerogative was a comparatively newer concept in terms of its use in England and Scotland. It did not appear in Scotland until the late $1590 \mathrm{~s}^{61}$ For the purposes of this thesis, I have interpreted the royal prerogative as an extension and practical application of arcana imperii (secrets or mysteries of state). ${ }^{62}$ Also described as the "handicraft or trade of kings," mysteries of state can be understood as the secret act of governing, the decision- and policy-making aspect of rule; itself a changeable and undefined process known only to the ruler. Successful statecraft required the monarch to rule prudently, protecting his or her authority while safeguarding the kingdom;

\footnotetext{
58 See Susan Dwyer Amussen, An Ordered Society: Gender and Class in Early Modern England (New York: Columbia University Press, 1993), 1-2, 37, 46; Sarah Hanley, "Engendering the State: Family Formation and State Building in Early Modern France," French Historical Studies 16 (1989): 4-27; Johanna Rickman, Love, Lust, and License in Early Modern England: Illicit Sex and the Nobility (Aldershot and Burlington: Ashgate, 2008), 11.

$59 \mathrm{JPW}, 47$.

60 Merton, 138

61 Goodare, Government, 99.

62 William Blackstone, Commentaries on the Laws of England, ed. William Carey Jones, vol. 1 (San Francisco: BancroftWhitney Company, 1916), 355.
} 
and the mysteries of state or royal prerogative allowed for this. Due its secretive nature, a "'zone of silence'” surrounded mysteries of state, giving freedom of action to the monarch while also prohibiting the questioning or discussion of his or her motives, decisions, or deeds. ${ }^{63}$ James stated, "The art of government is a deep Mystery," conveying its private, secret nature, and he referred specifically to "my Prerogative or mystery of state." 64 Thus, James, too, coupled the royal prerogative with mysteries of state, conceiving them as one and the same. Relevant to this thesis, both Elizabeth and James used the "silence" of the royal prerogative to manage noble marriages and to initiate unwritten crown policies, as illustrated in chapters three and four. The royal prerogative also protected their right to punish subjects as they chose, as described in chapter five.

The necessity of the royal prerogative was bolstered, in part, by sixteenthcentury political writings. Authors Niccolò Machiavelli and Jean Bodin, in particular, accepted a ruler's need to secure his or her position and state security by any means. In The Prince, first published in 1513, Machiavelli wrote that "one of the most important tasks a prince must undertake" was "to satisfy the people and keep them content." To that end, a ruler "should appear to be compassionate, faithful to his word, guileless, and devout... But his disposition should be such that, if he needs to be the opposite, he knows how." For the maintenance of his state, a prince "is often forced to act in defiance" of virtuous traits and though "he should not deviate from what is good, if that is possible... he should know how to do evil, if that is necessary." Thus, Machiavelli's view suggested that the safeguarding of a kingdom's stability sometimes required superseding moral, ethical, or perhaps legal standards, though it was still imperative that a prince "appear to" abide by those standards. ${ }^{65}$

Building upon Machiavelli's general idea that a ruler should be prepared to act contrary to established social values, Bodin's Six Books of the Commonwealth (1576) further asserted that "the distinguishing mark" of a ruler was "that he cannot in any way be subject to the commands" or limitations of others, "for it is he who makes law... That is why... the prince is above the law." According to Bodin,

${ }^{63}$ Ernst H. Kantorowicz, "Mysteries of State: An Absolutist Concept and Its Late Mediaeval Origins," Harvard Theological Review 48 (1955): 68n, 69.

$64 \mathrm{JPC}, 41 ; J P W, 212$.

65 Machiavelli, 105, 100-101. 
because a prince was "not subject to his own laws," he was able to "set aside the laws" if they were unjust "without the consent of his subjects." Thus, Bodin overtook Machiavelli's notion that a prince should always appear virtuous and justified the overriding of legal boundaries or any other limitations to his rule. According to Bodin, the ruler was "bound by the just and reasonable engagements which touch the interests of his subjects," but those would be determined by the ruler himself.66 The ideas of continental political writers Machiavelli and Bodin reinforced usage of the royal prerogative by contending that monarchical actions which evaded moral, ethical, or legal constraints for the preservation of the state and good of the people were acceptable; they were politically prudent. In the Elizabethan and Jacobean periods important legal figures like Sir Francis Bacon, Sir Edward Coke, and others wrote variously in support of or against the monarchs' employment of the royal prerogative, validating its utilisation or highlighting its contentious nature. ${ }^{67}$

James clarified his interpretation of the monarch's relationship to law and the inclusion of a moral component, conscience, over which only he was governable: "Whatsoever a private Man ought to do by Law, a King is bound to do by Conscience."68 In his The Trew Law of Free Monarchies, he acknowledged that "a good King, although he be above the Law, will subject and frame his actions thereto, for examples sake to his subjects, and of his own free-will, but not as subject or bound thereto."69 James's ideas on monarchical powers versus laws corresponded with Bodin's view that a ruler was not compelled to follow laws in the same sense as his subjects, rather his moral obligation and sense of honour ensured compliance. ${ }^{70}$ In this sense, the monarch could claim primacy of position and moral judgement as secured by divine right, engaging the possibility of law evasion because he or she was not strictly bound by it.

The legal limitations of the royal prerogative were uncertain. In theory, common law could be used to restrain actions of the monarch or Parliament,

\footnotetext{
66 Jean Bodin, Six Books of the Commonwealth, abr. and trans. M. J. Tooley (1955; reprint, Oxford: Basil Blackwell, 1967), 28, 29-30.

${ }^{67}$ See Francis Bacon, An Essay of a King (London: Printed for Richard Best, 1642); Edward Coke, The Reports of Sir Edward Coke, Knt, eds. John Henry Thomas and John Farquhar Fraser, vol. 6 (London: John Butterworth and Son, 1826), 159-166, 202-210; Walter Raleigh, The Prerogative of Parliaments in England (Midleburghe: s.n., 1628).

$68 \mathrm{JPC}, 42$.

$69 \mathrm{JPW}, 75$.

70 Bodin, 28-29; Black, 27.
} 
preventing any statute or crown act which might be "against any common right and reason, or repugnant, or impossible to be performed". ${ }^{71}$ But when the monarch summoned and dissolved Parliament at will ${ }^{72}$ and controlled judge appointments, the ability of common law to inhibit monarchical activities did seem theoretical indeed. ${ }^{73}$ As a result, the legally controversial royal prerogative became associated with absolutism because it encompassed the monarch's power or ability to act freely-outside of established laws, Parliament, courts, or other governing bodies - due to his or her supreme position and divine right. ${ }^{74}$ Historian Gerhard Oestreich has determined that the marginalisation of other administrative groups was the essence of absolute monarchy, itself "characterised by its tendency to exclude other forces from participation in national government", particularly those which represented "opposition to the... ambitions of the prince."75 Other historians like Julian Goodare, Conrad Russell, and John Miller, among others, have discussed exclusive monarchical privileges, particularly the free hand of the royal prerogative, and their connection with absolutism in England and Scotland. ${ }^{76}$ As mentioned in the introduction, however, the nobility generally supported the monarchy.

Like their continental counterparts, Elizabeth and James embraced the royal prerogative and, therefore, in theory, aspects of absolutism. ${ }^{77}$ Elizabeth invoked the royal prerogative early in her reign when facing pressure to marry to provide for a stable succession. She gave the House of Lords only "a silent thought" to their request that she wed and refused to debate the issue. ${ }^{78}$ As stated above, the act of silence "in church and court" was related to arcana imperii or mysteries of state. ${ }^{79}$ In fact, the 1581 "Statute of Silence" barred debate on the succession though previous Parliaments, particularly those of Henry VIII, had debated the

\footnotetext{
71 Russell, James, 149.

72 Ibid, 142; Bodin, 31-32.

73 Miller, ed., 203; Russell, James, 143.

74 Russell, James, 143; Miller, ed., 30; Kenyon, ed., 7-9.

75 Gerhard Oestreich, Neostoicism and the Early Modern State, ed. Brigitta Oestreich and H. G. Koenigsberger, trans. David McLintock (Cambridge: Cambridge University Press, 1982), 259.

76 Goodare, Government, 89-91; Russell, James, 143; Miller, ed., 197; Kenyon, ed., 7-9; Elton, ed., 17-18, 311.

77 Black, 27; Ignacio Atienza Hernández, “'Refeudalisation' in Castile during the Seventeenth Century: A Cliché?," in The Castilian Crisis of the Seventeenth Century, ed. I. A. A. Thompson and Bartolomé Yun Casalilla (Cambridge: Cambridge University Press, 1994), 267.

78 ECW, 79.

79 Kantorwicz, "Mysteries of State," 69.
} 
topic. $^{80}$ For the remainder of her rule, the queen requested that members of Parliament avoid deliberation or discussion of all matters that she had determined were within the royal prerogative: dynastic marriage, succession, religion and church governance, and foreign policy, demanding that they "meddle with no matters of state but such as should be propounded unto them, and to occupy themselves in other matters concerning the common wealth." 81

Elizabeth also drew upon the royal prerogative through High Commission and Star Chamber courts when punishing unauthorised noble marriages, especially those that had a bearing on the succession as will be illustrated in chapter five. The High Commission was an ecclesiastical court whose judges were selected by the monarch and Star Chamber was a secular court in which the monarch's own privy councillors sat as judges. Each began as an ad hoc monarch-initiated prerogative court and developed into a regularly-sitting body in its own right though both were still influenced by the crown. ${ }^{82}$ The 1591 Caudrey Case in the English courts upheld the royal prerogative in relation to church governance and High Commission court, determining that "this kingdom of England is an absolute empire and monarchy," the king or queen being "furnished with plenary and entire power, prerogative and jurisdiction."83 Understandably, Elizabeth later described her royal prerogative as "the chiefest flower in her garland, and the principal and head pearl in her crown and diadem" as it allowed for independence of rule, the ability to determine and prolong the punishments of offenders regardless of court findings, and the power to build supportive patronage networks through its benefits. ${ }^{84}$

James's own view on the royal prerogative was distinct: "give me no more in my private Prerogative, than you give to any subject... as for the absolute [royal] Prerogative of the Crowne, that is no subject for the tongue of a Lawyer." Equally, he asserted that no one should "meddle with the Kings Prerogative... that which

\footnotetext{
80 SR, vol. 4, 659-661; Diana Newton, "Francis Hastings and the Religious Education of James VI and I," HJ 41 (1998): 918n. Parliament had been actively involved in matters relating to religion and the succession in Henry VIII's reign, especially regarding the act of supremacy, the two suppression acts, and three succession acts.

81 T. E. Hartley, ed., Proceedings in the Parliaments of Elizabeth I, vol. 1 (Leicester: Leicester University Press, 1981), 199; Doran, Circle, 222; Elton, ed., 17-18, 311; Newton, 918n.

82 P. B. Waite, "The Struggle of Prerogative and Common Law in the Reign of James I," Canadian Journal of Economics and Political Science 25 (1959): 144.

83 Coke, vol. 3, xxvii; Lockyer, Britain, 248.

${ }^{84}$ Hartley, ed., vol. 3, 242.
} 
concerns the mystery of the Kings power, is not lawful to be disputed." 85 James's declarations referred to the royal prerogative as mysteries of state, and he invoked this privilege primarily on issues regarding religion and church governance, foreign policy, the dynastic marriages of his children, and the courts. ${ }^{86}$ Indeed, from the 1590s these issues, traditionally within the remit of the Scottish Parliament, were removed, becoming crown responsibilities. ${ }^{87}$ Accepting the limitations of his royal prerogative, James claimed that he must "manage his authority boldly, and yet temperately, not stretching his royal Prerogative but where necessity shall require it." 88 James also used the royal prerogative to handle marriages through High Commission and Star Chamber, courts which served to reinforce crown policies and ideas when patronage of the transgressing newlyweds was not an option. And, like Elizabeth, James alone determined the conditions and necessity of royal prerogative utilisation rather than other administrative, judicial, or religious bodies.

As mentioned, one specific way in which Elizabeth and James employed the royal prerogative for the management of noble marriages was by means of their authority over the church. From 1559 the monarch has been the supreme governor of the Church of England and was head of the Scottish kirk from 1584 to 1690.89 Though the canon laws of both churches originated from Roman Catholicism, in Elizabeth's and Mary, queen of Scots' reigns, marriage lost its status as a sacrament which was consistent with reformed church principles. ${ }^{90}$ On the whole, marriage-related canon laws were similar in Elizabeth's and James's reigns: none could marry within the prohibited degrees of kindred and affinity or without parental or guardian consent, marriages had to be conducted in a church, and no

\footnotetext{
$85 \mathrm{JPW}, 214,213$.

86 Lockyer, Britain, 238.

87 Goodare, Government, 99.

$88 \mathrm{JPW}, 249$; Russell, James, 106.

${ }^{89}$ Henry VIII gained jurisdiction over the Church of England in 1534 with the Act of Supremacy. See SR, vol. 3, 492, 548549, 575-578, 663-666. Elizabeth regained jurisdiction over the Church of England after Mary I's death, making it Protestant once more. See $S R$, vol. 4, 350-355. The 1560 Scottish Parliament adopted a Protestant confession of faith (RPS, A1560/8/3), and papal jurisdiction was officially abolished in 1567 (RPS, 1567/4/6). The so-called Black Acts of 1584 established royal authority over spiritual and temporal states $(R P S, 1584 / 5 / 8)$ and ended the convention of spiritual or temporal councils without special commandment (RPS, 1584/5/10).

${ }^{90}$ In England, the Ten Articles of 1536 removed marriage from the list of sacraments. See Church of England, Articles Devised by the Kinges Hyghnes Maiestie to Stablyshe Christen Quietnes and Vnitie Amonge Vs (London: Thomas Bertheleti, 1536); Anonymous, The Institution of a Christen Man (London: Thomas Bertheleti, 1537). For Scotland see RPS, A1560/8/3; Church of Scotland, The First and Second Booke of Discipline (Amsterdam: G. Thorp, 1621); Carlson, 3, 8, 42.
} 
minister could celebrate a marriage without either thrice-read banns or a valid marriage licence. ${ }^{91}$

Abiding by the proper conduct of marriage celebration as outlined in canon law ideally ensured that noble, indeed all, marital unions were legitimate and binding. Trouble most frequently occurred in the event of noble clandestine marriages, which often ignored aspects of correct marriage solemnisation and resulted in royal punishment. It should be remembered that as supreme governor , the monarch enjoyed the privilege of naming ecclesiastical leaders and judges and had, consequently, the potential to influence them. ${ }^{92}$ Elizabeth and James did interfere and exert their influence over certain marriages to guarantee verdicts or punishment of offenders through ecclesiastical courts. It was in those moments that manipulation of their position as church head became markedly visible.

Furthermore, Henry VIII's 1536 Treason Act, which had strictly controlled the marriages of royalty and members of the nobility with royal blood, had been repealed in 1547.93 This meant that by the beginning of Elizabeth's reign in 1558, no statutory laws existed which might aid in the management of royal or noble marital alliances. As this thesis argues, it was through plural prerogative of wards' marriages, in loco parentis duties, and the royal prerogative that potentially threatening marriages could be managed. Because noble marital alliances might strengthen or destabilise the monarchy, exclusive crown rights protected the monarch's ability to act for or against a marriage for the protection of royal authority. For these reasons, prerogative courts like High Commission and Star Chamber were summoned by the monarch and repeatedly served to reinforce his or her influence and crown privileges in the field of noble marriage. ${ }^{94}$

Elizabeth's and James's authority over noble marriages resided in the dual prerogatives, plural and the royal, in loco parentis rights, and marriage-related canon laws which were enforceable through prerogative courts. These different

\footnotetext{
${ }^{91} A C, 191,205,225,399,401 ; S R$, vol. 4, 351; RPS, A1567/12/15; Church of Scotland, 62-64. See also Rickman, 16 England's Parliament sought to prevent clandestine marriage with the 1753 Marriage Act which required a formal wedding ceremony.

92 Miller, ed., 203; Russell, James, 143.

93 SR, vol. 3, 680-681. The Treason Act of 1536 was repealed in 1547 in King Edward VI's reign. See SR, vol. 4, 18-22. From 1547 until the Royal Marriages Act of 1772 there were no laws which governed the marriages of royalty or members of the nobility with royal blood. See David M. Head, "Beyng Ledde and Seduced by the Devyll': The Attainder of Lord Thomas Howard and the Tudor Law of Treason," SCJ13 (1982): 3-16.

94 Waite, 144.
} 
privileges enabled Elizabeth and James to supervise and intervene effectually in aristocratic marital alliances to maintain royal authority. In addition, the benefits associated prerogatives allowed Elizabeth and James to build much-needed patronage networks with the nobility. Both monarchs supported the alignment of families that would serve them well and opposed those that were potentially threatening or would work against established government agendas, particularly relating to religion, succession, and Anglo-Scottish union. Indeed, the monarch and the nobility were irrevocably linked and their cooperation was necessary for safeguarding both crown and noble authority, implementing policies, and stabilising the state. Thus, one purpose of this study is to highlight the important role marriages played in bringing together the monarch and nobility. These often highly celebrated events provided the monarch with opportunities to establish vital and mutually beneficial patron-client relationships with the nobility. This thesis reveals that the careful management of these marital alliances was not only a critical function of the monarchical office but also an important factor in perpetuating the hierarchy of royal power.

\section{Database}

Database analysis has revealed a broader view of each monarch's noblemarriage management practice and the changing patterns of involvement across reignsThis examination has aided in inferring levels of monarchical control and participation. Evaluation of the database has answered the question of how often participation might have been associated with a selected crown policy-religion, succession, or Anglo-Scottish union. The findings also have provided metrics on the success rates of monarchical support based on the duration of patron-client relationships established at the time of the wedding. As Table 2.1 shows, 162 noble marriages have been recorded for the Elizabethan period and the queen had imputed involvement at least fifty-eight times (36\%). For James's reign of Scotland and England, from the initiation of personal rule of Scotland in 1585 until his death in 1625, 218 noble marriages have been logged. From these James had imputed participation at least seventy-one times (33\%). Compared to James, Elizabeth was 
Table 2.1: Monarchical involvement in noble marriages $(n=380)$

\begin{tabular}{ll|l} 
& $\begin{array}{l}\text { Elizabeth I } \\
\text { Total Involvement/ } \\
\text { Total Marriages (\%) }\end{array}$ & $\begin{array}{l}\text { James VI/I } \\
\text { Total Involvement/ } \\
\text { Total Marriages (\%) }\end{array}$ \\
\hline $1558-1569$ & $19 / 41(46 \%)$ & - \\
$1570-1579$ & $19 / 45(42 \%)$ & - \\
$1580-1589$ & $9 / 37(24 \%)$ & $7 / 15(47 \%)$ \\
$1590-1599$ & $7 / 26(27 \%)$ & $13 / 26(54 \%)$ \\
$1600-1609$ & $4 / 13(31 \%)$ & $25 / 68(37 \%)$ \\
$1610-1619$ & - & $13 / 68(19 \%)$ \\
$1620-1625$ & - & $13 / 41(32 \%)$ \\
Total & $\mathbf{5 8 / 1 6 2 ( 3 6 \% )}$ & $\mathbf{7 1 / 2 1 8 ( 3 3 \% )}$
\end{tabular}

slightly more active in marriage intervention which challenges Brown's view that she had a "relatively lax approach" to noble unions. ${ }^{95}$

As the data reveal, the majority of noble marriages were subjected to no crown involvement at all. One explanation for the low percentage of participation resides in the very nature of hierarchy-the vertically-aligned, asymmetrical system that dominated all aspects of early modern life. Lack of any involvement whatsoever might reasonably be attributed to the fact that omnipresent hierarchies, whether monarch-noble, husband-wife, father-child, master-servant, were so firmly entrenched in the early modern mind-set that it was a system that sustained itself, regardless of who was on the throne. ${ }^{96}$ Members of the aristocracy made decisions concerning marriage that upheld the hierarchical system of which they were not only a part, but were more closely connected to the apex than most. As a result, it would be unnecessary for the monarch to become involved in the majority of marriages, especially those among the less powerful or lower-level nobility, simply because these unions preserved the system over which he or she ruled. And this is precisely why it is critical to examine the marriages in which Elizabeth or James did become involved in order to elucidate the motives and implications behind their engagement.

That said, I still believe that these percentages of noble-marriage involvement, 36\% for Elizabeth and 33\% for James, represent minimum amounts and it is probable that they participated in more weddings than are logged here.

95 Brown, Noble Society, 126.

96 I thank Professor Jonathan Scott for highlighting this point. 
As mentioned in the introduction, details on the marriages captured in the database were often gathered from multiple sources to form a clear picture of the union. It seems that despite the significance of marriage in the early modern period relatively few details have survived even among the nobility. This might explain Elizabeth's or James's minority stake in noble marriages reflected in the database. In addition, it would have been neither feasible nor necessary for the monarch to have become involved in every noble marriage that took place during his or her reign. Most logical is that duties of state precluded them from participating. Moreover, the monarch may not have possessed a clear right to intervene like the plural prerogative of wards' marriages or an in loco parentis duty. The database does show that both monarchs appear to have participated in weddings of those noble courtiers whom they knew well. And, those closest to the monarch stood a greater chance of securing patronage and other crown benefits. Logically, monarchs would have been less likely to participate in the marriages of those peers who did not attend court regularly or with whom they were unfamiliar. Geographical proximity may also have played a role in the low percentages of involvement. It has appeared that Elizabeth limited her attendance to those unions which took place in and around London or while she was on progress. ${ }^{97}$ Prior to 1603 , James participated in marriages in and around Stirling and Edinburgh. After ascending the English throne, he mainly attended weddings in London. ${ }^{98}$ Furthermore, the union of the crowns substantially increased the number of aristocratic marriages to manage and the overall involvement percentage consequently decreased. Adding to that, James's rule in England through his favourite courtiers, particularly George Villiers, first duke of Buckingham, may have diminished or hidden his personal oversight of marriages. Buckingham himself actively brokered multiple unions, especially those which linked members of his extended family to nobility. ${ }^{99}$ What appears to be a low percentage of involvement in marital alliances can be attributed to all of these factors-proximity and acquaintance, sheer numbers and necessity. Nevertheless,

${ }^{97}$ See Mary Hill Cole, The Portable Queen: Elizabeth I and the Politics of Ceremony (Amherst: University of Massachusetts Press, 1999), 180-201.

98 For example, James attended weddings in Stirling, Callander, and Edinburgh. See TNA, SP 52/55/104; ibid, SP 52/59/29; David Moysie, Memoirs of the Affairs of Scotland (Edinburgh: The Bannatyne Club, 1830), 69. See chapter three for weddings he attended in London, some of which were Anglo-Scottish marriages.

${ }_{99}$ Buckingham was likely involved in brokering the 1619 Maxwell-Beaumont, 1620 Cranfield-Brett, 1622 Villiers-

Sheldon, and 1622 Hamilton-Feilding marriages. See the appendix. 
this thesis will demonstrate that noble-marriage management was a regularlyused tool of the monarchical office and an important means of establishing monarch-noble ties and advancing royal authority.

When analysed by decade, the database reveals that in the first twenty years of her reign Elizabeth vigorously managed noble marriages. The period between her ascension in late 1558 to 1579 had the highest frequency of weddings and most active participation-two-thirds of all of Elizabeth's involvement in noble marriages took place in these years. This suggests that as the queen positioned herself firmly on the throne she repeatedly sought connections with her nobility through their marriages to uphold her authority. From the 1580s until the end of her reign, the frequency of marriages decreased although Elizabeth's participation rate averaged around 27\%. While these lower percentages of participation in the latter part of the reign may be indicative of the queen's general feeling of security on the throne, the slight uptick from 1580 to 1603 suggests otherwise. This minor surge in involvement may have related to parliamentary discussion on crown privileges as mentioned in the introduction, particularly around monopolies. ${ }^{100}$ These debates likely pressed the need to connect with the nobility for support through supportive marriage participation. Overall, Elizabeth elevated few and the number of peers remained stable throughout her reign. Likely a combination of financial constraints and "snobbishness," Elizabeth's strategy to limit peerage elevations gained her a reputation for miserliness but it allowed her to balance skilfully the power between monarch and nobility, keeping the latter's numbers and, thus, patronage needs in check. ${ }^{101}$

James's noble-marriage management peaked in the 1590s, his first full decade on the Scottish throne after attaining his majority. From 1590 to 1599, the king participated in more than half of the recorded weddings among the Scottish nobility. This indicates that marital alliances were of importance to his authority and the stability of his kingdom. With his ascension to the English throne in 1603, James had two aristocracies to manage and the frequency of their marriages increased. At the same time, his removal from Scotland to England prevented

\footnotetext{
100 John Guy, Elizabeth: The Forgotten Years (New York: Viking, 2016), 352-353, 360-361; Elton, ed., 311. 101 Stone, Crisis, 97-99. See also John Hayward, Annals of the First Four Years of the Reign of Queen Elizabeth (London: J. B. Nichols and Son, 1840), 15.
} 
Table 2.2: Monarchical involvement by strategy $(n=129)$

\begin{tabular}{ll|l|l} 
& $\begin{array}{l}\text { Support/ } \\
\text { Total Involvement (\%) }\end{array}$ & $\begin{array}{l}\text { Non-participation/ } \\
\text { Total Involvement (\%) }\end{array}$ & $\begin{array}{l}\text { Opposition/ } \\
\text { Total Involvement (\%) }\end{array}$ \\
\hline Elizabeth I & $38 / 58(66 \%)$ & $12 / 58(20 \%)$ & $8 / 58(14 \%)$ \\
James VI/I & $63 / 71(89 \%)$ & $3 / 71(4 \%)$ & $5 / 71(7 \%)$
\end{tabular}

attendance at weddings in his northern kingdom. James's involvement rate dipped to less than $20 \%$ from 1610 to 1619 ; the least amount of participation recorded. By 1610 James's Anglo-Scottish union dream and the "Great Contract" had failed. ${ }^{102}$

The 1610s saw the death of Salisbury and the shift to the king's "favourite" and gentlemen of the bedchamber through whom much subsequent government and patronage action would flow. ${ }^{103}$ During this decade disapproval mounted regarding royal favourites, crown financial strains, discussions over a proposed marriage between Prince Charles and the Spanish infanta, and the possibility of war with Spain. ${ }^{104}$ However, from 1620 to his death in 1625, James's participation rate increased considerably. This escalation may have served to accommodate the growing number of nobility from two kingdoms, absorbing the king's initial penchant for creating new peers and later venture in selling honours. ${ }^{105}$ The intensification of advocacy may also have been a response to criticism and disorder which stemmed from the 1610s. Stronger pro-monarch connections would bolster royal supremacy, especially against the Commons's growing opposition towards exclusive crown rights. The controversy over monopolies played a part in the Buckingham-Manners marriage discussed in chapter three.

The three strategies for managing noble marriages, already briefly presented in the introductory chapter, included support for a couple through patronage, discussed in chapter three; purposeful non-participation and isolation from royal favour, examined in chapter four; and opposition and punishment

102 Lindquist, 619-620; Russell, James, 167.

103 Neil Cuddy, "The Revival of the Entourage: The Bedchamber of James I (1603-1625)", in The English Court: From the Wars of the Roses to the Civil War, ed. David Starkey (London: Longman, 1987), 173, 181, 183; Robert Hill and Roger Lockyer, "Carleton and Buckingham: The Quest for Office' Revisited," History 88 (2003): 30; Christiane Hille, Visions of the Courtly Body: The Patronage of George Villiers, First Duke of Buckingham, and the Triumph of Painting at the Stuart Court (Berlin: Akademie Verlag, 2012), 101-102.

104 Russell, James, 180, 183-184; Samuel R. Gardiner, History of England from the Accession of James I to the Outbreak of Civil War, 1603-1642, vol. 3 (London: Longmans, Green, and Co., 1883), 345; CSPV, 1619-1621, xl-xli. The treasury was empty and a princess's dowry, i.e., the Spanish infanta's, would remedy the dire need. Many opposed the king's attempts to marry his heir Prince Charles to a Catholic bride. See Roger Lockyer, Buckingham: The Life and Political Career of George Villiers, First Duke of Buckingham 1592-1628 (London and New York: Longman, 1981), 18-19.

105 Stone, Crisis, 100-101. 
which is the focus of chapter five. Detailing the previous chart, Table 2.2 shows Elizabeth's and James's noble-marriage involvement by strategy. While they employed these strategies for different reasons, both monarchs showed an overwhelmingly supportive approach to marriages. This reveals the importance of connecting positively with the nobility through sponsorship and patronage and refocusing new family alliances and allegiances towards the crownIn addition, the above strategies sometimes coincided with the selected crown policies or agendas: religion, succession, and Anglo-Scottish union. As mentioned in the introduction, the marriages described in the following chapters are organised according to strategy and any connections between strategies and royal programmes are explained.

\section{Crown policies}

In early modern Europe the term "policy" had various meanings, including the practice of government, a course of action, prudent or expedient behaviour, cunning or craftiness. ${ }^{106}$ These definitions are reminiscent of the mysteries of state and royal prerogative - the silent, subtle craft of kingship-and suggest that policies were shrewdly and carefully employed to direct the commonweal, nurture certain ideals, and maintain royal supremacy. This thesis concentrates on Elizabeth's and James's policies regarding religion, succession, and Anglo-Scottish union and how both monarchs used noble marriages to convey their imperatives. Their policies, discussed below, sought to safeguard Protestant reforms, secure the succession, and foster a closer union between England and Scotland. Copious amounts of scholarly research have already focussed on each of the selected policies. My purpose is not to engage heavily in the discussions on these policies but rather to use them as a guide to achieve connecting aims. First, I outline Elizabeth's and James's main objectives relating to each royal programme. Then, in the following case-study chapters three through five, I ascertain how these objectives might have been achieved through supervision of and participation in noble marital alliances. To aid in this assessment, the database has provided statistics on marriages and myriad aspects of monarchical management and involvement related to policies.

106 OED, s.v. "policy, n. 1." See also Robert Cawdry, A Table Alphabeticall (London: Printed by I. R[oberts], 1604), s.v. "pollicie." 
Table 2.3: Policy-related monarchical involvement in noble marriages $(n=129)$

\begin{tabular}{ll|l} 
& $\begin{array}{l}\text { Elizabeth I } \\
\text { Policy-related Involvement/ } \\
\text { Total Involvement (\%) }\end{array}$ & $\begin{array}{l}\text { James VI/I } \\
\text { Policy-related Involvement/ } \\
\text { Total Involvement (\%) }\end{array}$ \\
\hline $1558-1569$ & $8 / 19(42 \%)$ & - \\
$1570-1579$ & $9 / 19(47 \%)$ & - \\
$1580-1589$ & $4 / 9(44 \%)$ & $1 / 7(14 \%)$ \\
$1590-1599$ & $2 / 7(29 \%)$ & $2 / 13(14 \%)$ \\
$1600-1609$ & $0 / 4(0 \%)$ & $8 / 25(32 \%)$ \\
$1610-1619$ & - & $7 / 13(54 \%)$ \\
$1620-1625$ & - & $6 / 13(46 \%)$ \\
Totals & $\mathbf{2 3 / 5 8 ( 4 0 \% )}$ & $\mathbf{2 4 / 7 1 ( 3 4 \% )}$
\end{tabular}

Noble marriages that connected to a crown policy or programme have been designated as such in the database. For example, unions associated with Elizabeth's or James's religious policy are ones in which the religious denomination of either one or both of the couple was a highly visible aspect of the pending alliance, one that is still noted in reference sources. Likewise, marriages that linked English and Scottish noble subjects have been designated as Anglo-Scottish union alliances, just as those that involved claimants to the throne have been termed succession-related. Following this process, Table 2.3 shows the level of policy-related involvement of both monarchs. I have linked one-third or more of the marriages in which Elizabeth or James participated to a royal programme. This suggests that religion, succession, or Anglo-Scottish union were important issues of the period and that both monarchs believed they might realise their agendas in some manner through intervention in marriages. However, these low percentages may reveal that Elizabeth or James did not use patronage of noble marriages as a mainstay for communicating policies. Furthermore, it is possible that, generallyspeaking, they did not align patronage with policy which relates to Peck's research on patron-client relationships described in chapter one. Table 2.4 reveals that the applicability of the selected policies varied per monarch, explaining the differences of percentages between them. Chapter three will discuss the connections between policy and patronage, their prevalence and success. 
Table 2.4: Monarchical involvement by policy $(n=47)$

\begin{tabular}{ll|l|l} 
& $\begin{array}{l}\text { Religious Policy / } \\
\text { Total Policy-related } \\
\text { Involvement }\end{array}$ & $\begin{array}{l}\text { Succession Policy/ } \\
\text { Total Policy-related } \\
\text { Involvement }\end{array}$ & $\begin{array}{l}\text { Anglo-Scottish Union Policy/ } \\
\text { Total Policy-related } \\
\text { Involvement }\end{array}$ \\
\hline Elizabeth I & $18 / 23(78 \%)$ & $5 / 23(22 \%)$ & $0 / 23(0 \%)$ \\
James VI/I & $10 / 24(42 \%)$ & $1 / 24(4 \%)$ & $13 / 24(54 \%)$
\end{tabular}

Religion

Table 2.4 indicates that more than three-quarters of Elizabeth's policyrelated intervention in marriages was related to the safeguarding of Protestantism. The majority of these religion-designated marriages occurred in the first twenty years of her reign, suggesting keen and purposeful handling of these unions as the religious settlement became more firmly established. These marriages will be analysed fully in chapter three. Though decreasing in frequency from 1580, weddings that linked her religious policy continued to occur in Elizabeth's reign. Alliances which had an overt religious component make up more than $40 \%$ of all James's policy-related involvement. His participation took place steadily, regularly joined Catholic and Protestant, bringing Catholic subjects to the Protestant church. In terms of his total participation, James's religion-linked involvement fell short of his promotion of Anglo-Scottish union, likely because the firm securing of Protestantism was less of an issue during his reign. These wedding are examined in chapter three.

Both Elizabeth and James succeeded Catholics. This made their early years on the throne tumultuous as religious questions were settled in favour of Protestantism. The reformed religion dominated their reigns and understanding its nature and influence on the crown, government, and society has been critical to analysing noble-marriage management. Modern scholarly works by Doran, Patrick Collinson, Diarmaid MacCulloch, and others have shed light on the Reformation in England as well as the religious beliefs of the queen herself. ${ }^{107}$ Elizabeth's first

107 See Patrick Collinson, The Religion of Protestants: The Church in English Society (Oxford: Oxford University Press, 1982); idem, Elizabethans, 2nd ed. (London and New York: Hambledon and London, 2003); Susan Doran, "Elizabeth I's Religion: The Evidence of Her Letters," Journal of Ecclesiastical History 51 (2000): 699-720; idem, Elizabeth I and Religion, 1558-1603 (London and New York: Routledge, 1994); Diarmaid MacCulloch, "Putting the English Reformation on the Map," TRHS 15 (2005): 75-95; idem, "The Myth of the English Reformation." Journal of British Studies 30 (1991): 1-19. Other helpful works include David Cressy and Lori Anne Ferrell, eds., Religion and Society in Early Modern England: A Sourcebook, 2nd ed. (New York and London: Routledge, 2005); Karl Gunther, Reformation Unbound: Protestant Visions of Reform in England, 1525-1590 (Cambridge: Cambridge University Press, 2014); Christopher Haigh, 
Parliament in 1559 removed the connection with Rome that had been revitalised during her sister's short reign. Combining Protestant and Catholic elements, the discipline of the Church of England served the queen's own preferred via media approach which, according to Collinson, was built from her own religious conservatism but would also be acceptable to most of her subjects-a political necessity. 108 In MacCulloch's view, this signalled the queen's lack of "enthusiasm for high-temperature religion," whether zealously Catholic or Protestant. 109

The Elizabethan Settlement represented the key aims of the queen's overt religious policy: firm establishment of a Protestant Church of England with monarchical primacy and episcopal governance; compliance of all clergy and laity to the Church of England; and kingdom-wide uniformity of worship. ${ }^{110}$ Though Elizabeth's reformed Church of England emphasised standardisation and obedience, from the late 1560 s it faced numerous disturbances. Although there was a pervasive call among many Protestants for the Church of England to undergo further reform, much unrest was aimed at returning England to Rome. ${ }^{111}$ This move was aided by the arrival in northern England of the unseated Catholic Mary, queen of Scots, in 1568 and the Northern Uprising in 1569 which resulted in Pope Pius V's bull of 1570, Regnans in Excelsis. The papal bull excommunicated Elizabeth and absolved her subjects of submission to her. English Catholics, who had hitherto been largely left alone, suddenly were, in David Loades' words, "required to choose between their religion and their allegiance."112

After 1570, the growing belief in England was that "Catholics were traitors" to queen and country if they did not attend church. ${ }^{113}$ As a result, the government resorted to increasingly harsh penalties toward Catholics and others who did not conform. Parliament met in 1571 to pass several acts to address the threat Catholics posed to Elizabeth herself and the stability of the kingdom and national church. ${ }^{114}$ Thus, the statutes which formulated the Elizabethan Settlement were

English Reformations: Religion, Politics, and Society Under the Tudors (Oxford: Oxford University Press, 1993); Nicholas Tyacke, Aspects of English Protestantism, c. 1530-1700 (Manchester: Manchester University Press, 2001).

108 Collinson, Elizabethans, 109-110.

109 MacCulloch, "Putting the English Reformation on the Map," 89.

110 Lockyer, Britain, 188-189; Doran, "Elizabeth I's Religion," 702.

111 Gunther, 13.

112 David Loades, Politics, Censorship and the English Reformation (London and New York: Pinter Publishers, 1991$), 76$.

113 Guy, 26.

114 SR, vol. 4, 526-531, 657-658, 706-708, 843-846. 
bolstered by additional laws to punish heretics, recusants, and others who refused to comply. And yet the Catholic plotting continued with the Ridolfi plot in 1571 and subsequent execution of England's premier peer Thomas Howard, fourth duke of Norfolk, in 1572; the Throckmorton plot in 1583; the Parry plot in 1585; the Babington plot in 1586, culminating in the beheading of Mary, queen of Scots, in 1587; the Spanish Armada attack in 1588, followed by four later attacks by Spain; and the Lopez plot in 1594. These events reflected the divisive nature of religion in Elizabethan society and the ensuing adaptation of the Church of England to ensure its survival. As a result, the Elizabethan Church gradually became more Calvinist and less Catholic from the 1570s, as Karl Gunther, Nicholas Tyacke, and others have noted, diverting from a via media approach. ${ }^{115}$

As Elizabeth's religious policy functioned to safeguard England's future as a Protestant country, her own dynastic marriage negotiations did the same. As Anne McLaren's research has indicated, the continuation of Protestantism in England played a central role in the dialogues over the queen's potential marital alliances. ${ }^{116}$ It follows that the perpetuation of the Church of England would also be a primary concern when managing the marriages of her noble subjects. Indeed, Daphne Pearson has suggested that the queen's unofficial religious policy was one which sought the "Protestantisation" of Catholic nobility. ${ }^{117}$ Its unwritten purpose was the marginalisation of Catholics, their removal from upper-level society, governing positions, and any influence garnered therefrom. In addition, the attempt to convert England's young Catholic aristocrats by encouraging their marriages to Protestants became a form of social engineering by the Elizabethan government, one which was made clear through the queen's management of their marriages as chapter three will show.

James, like Elizabeth, desired religious uniformity and conformity. ${ }^{118} \mathrm{He}$ preferred a hierarchically-structured church subject to royal authority that did not lean to either Catholic or Puritan extremism. ${ }^{119}$ His abundant speeches and

\footnotetext{
115 Gunther, 5; Nicholas Tyacke, Anti-Calvinists: the Rise of English Arminianism, c. 1590-1640 (Oxford: Oxford University Press, 1990), 3; Doran, Elizabeth I and Religion, 21; Diarmaid MacCulloch,"Sixteenth-century English Protestantism and the Continent," in Sister Reformations: The Reformation in Germany and in England, ed. Dorothea Wendebourg (Tübingen: Mohr Siebeck, 2010), 9.

116 McLaren, 264.

117 Pearson, 29.

$118 \mathrm{JPW}, 141$.

119 Jenny Wormald, “James VI and I,” History Today 52 (2002): 28; JPW, 140.
} 
writings shed light on his thoughts on religion and his role as monarch which, in turn, were suggestive of his religious agenda. Scholarly works by Jenny Wormald, Alan MacDonald, and others, have illuminated the king's religious position and policies. ${ }^{120}$ James clarified his views in the following statement:

\begin{abstract}
that I could wish from my heart that it would please God to make me one of the members of such a general Christian union in religion as, laying wilfulness aside on both hands, we might meet in the midst, which is the centre and perfection of all things. ${ }^{121}$
\end{abstract}

In the early years of his personal rule of Scotland, MacDonald has suggested that exerting royal power over the kirk necessitated James's pursuit of policies that promoted stability and compromise. ${ }^{122}$ This required him to work within the spectrum of religious beliefs, from Presbyterian to Catholic, to establish royal supremacy. ${ }^{123}$ But, as Wormald noted, “James's ... earliest political and ecclesiastical memory was of confrontation not with the Catholics but with the extreme Presbyterians," and, as a result, "his tolerance of Catholics at home would always owe more to personal than to political considerations."124

James's letters and speeches clearly revealed his opinions on religion and Catholicism in particular. In one letter to Salisbury, the king expressed his feelings on radical Catholics or Puritans: "I did ever hate alike both extremities in any case, only allowing the middes [middle course] for virtue." However, due to his respect for the Catholic Church, James wrote that he was "so far from any intention of persecution," lamenting only that the Catholic Church had become "clogged with many infirmities and corruptions." Furthermore, in writing to the English Catholic Henry Percy, ninth earl of Northumberland, on 24 March 1603, as yet unaware of Elizabeth's death, James wrote, “As for the Catholics, I will neither persecute any that will be quiet and give but an outward obedience to the law, neither will I spare

\footnotetext{
120 Scholarly works on James, religion, and the church which have been helpful in the development of this dissertation have included Jenny Wormald, Court, Kirk and Community: Scotland 1470-1625 (London: Edward Arnold, 1981); idem, "James VI and I," idem, “Gunpowder, Treason, and Scots," Journal of British Studies 24 (1985): 141-168; idem, "James VI and I: Two Kings or One?," History 68 (1983): 187-209; Alan R. MacDonald, The Jacobean Kirk, 1567-1625: Sovereignty, Polity and Liturgy (Aldershot: Ashgate, 1998); Margo Todd, The Culture of Protestantism in Early Modern Scotland (New Haven and London: Yale University Press, 2002); James Doelman, King James I and the Religious Culture of England (Woodbridge: D. S. Brewer, 2000); Cressy and Ferrell, eds., 147-168; Lockyer, Britain, 262-274.

$121 \mathrm{JPW}, 140$.

122 MacDonald, 30

123 Ibid, 30, 50; Doelman, 14.

124 Wormald, “Gunpowder," 148, 149.
} 
to advance any of them that will by good service worthily deserve it." 125 This correspondence alluded to James's ecclesiastical position which encompassed outward conformity to Protestantism and anti-radicalism and emphasised supremacy of and loyalty to the crown. ${ }^{126}$

When James ascended to the English throne in 1603, nothing similar to the Elizabethan Settlement was required. ${ }^{127}$ The Hampton Court conference, convened at the beginning of his reign and over which the king presided, upheld the position of the late Elizabethan church. James's ecclesiastical policy continued in its emphasis on royal supremacy and ostensible conformity to Protestantism, with an addition of uniformity between the churches of England and Scotland, including the re-establishment of episcopacy in Scotland. ${ }^{128}$ Apart from the issuance of new canons in 1604, an updated English version of the Bible, and a revised Book of Common Prayer, the governance and discipline of the Church of England remained the same. ${ }^{129}$ This was a disappointment to Catholics who believed James would convert and to Puritans who thought the Scots king would bring greater reform to the Church of England. ${ }^{130}$ In Scotland, the Five Articles of Perth, backed by James and eventually passed by Scotland's General Assembly in 1618, and ratified by Parliament in 1621, attempted uniformity of worship between the Churches of England and Scotland. ${ }^{131}$

It is likely that the experience gained as king of Scotland in managing different religious factions cleared the way for relative religious peace during James's reign of England. In fact, the king's ecumenism was revealed through church appointments: "he was determined to make the Church of England representative of a broad spectrum of protestant belief," though dedicated Calvinists still obtained the top positions. ${ }^{132}$ According to historian David Smith, it was one of James's greatest accomplishments "that religious issues figured so little

\footnotetext{
125 LKJ, 204-205, 207. Furthermore, "In the twenty-two years of James's English rule only twenty-five Catholics were executed, compared to 189 between 1570 and 1603." See ODNB, s.v. "James VI and I." $126 \mathrm{JPW}, 137-142$.

127 Doelman, 2.

128 Cressy and Ferrell, eds., 7-8.

${ }^{129}$ AC, 258-453; Derek Wilson, The People's Bible: The Remarkable History of the King James Version, with a foreward by Diarmaid MacCulloch (Oxford: Lion, 2011).

130 Lockyer, Britain, 262, 269.

131 Doelman, 15; MacDonald, 162-164. The articles were ratified by the Scottish Parliament in 1621. See RPS, 1621/6/13.

132 Lockyer, Britain, 266-267.
} 
in most of his Parliaments: that was a real tribute to his management of the Church of England and his capacity to defuse religious controversy."133 It was not until the final years of his reign that religion became a point of contention and trouble with the kirk and Church of England mounted. Difficulties arose on account of the Thirty Years' War in Europe, the "Spanish match" between Prince Charles and the Spanish Catholic Infanta Maria, and, when that foundered, the proposed marriage between Prince Charles and French Catholic Princess Henrietta Maria. ${ }^{134}$ Furthermore, the Five Articles had been a blow to those who wished to maintain the unique character of the Scottish church rather than have it "Anglicized." 135 Some considered the fifth article, which required kneeling communion to be unreservedly Catholic in nature. ${ }^{136}$ According to MacDonald, it was also a signal that James was "increasingly out of touch with Scotland" and the wishes of the Scottish kirk and people. ${ }^{137}$ For the remainder of his reign conformity to his religious programme including enforcement of the Five Articles would be an issue, neither being successfully achieved.138 In an atmosphere of growing anti-Catholicism, James pleaded for Christian unity in his 1622 Directions Concerning Preachers, commanding ministers to refrain from "bitter invectives, and indecent railing speeches, against the persons of either Papist or Puritan."139 James displayed his desires for religious harmony, conformity to Protestantism, uniformity of Protestant worship, and obedience to the crown, all aspects of his English and Scottish religious policies, through his handling of noble marital alliances as chapter three and four will show.

\section{Succession}

Early modern monarchs linked hereditary succession to the divine; it was sacred to the nature of kingship. ${ }^{140}$ Hereditary succession required marriage. A monarch's duty was to marry and produce heirs, providing a certain and

\footnotetext{
133 Smith, Stuart Parliaments, 111. See also Newton, 934; Wormald, “Two Kings or One?,” 204.

134 Smith, Stuart Parliaments, 111; ODNB, s.v. "James VI and I."

135 David Calderwood, The History of the Kirk of Scotland, ed. Thomas Thomson, vol. 7 (Edinburgh: Printed for the Wodrow Society, 1845), 352; Laura A. M. Stewart, "The Political Repercussions of the Five Articles of Perth: A Reassessment of James VI and I's Religious Policies in Scotland," SCJ 38 (2007): 1014-1015; MacDonald, 156.

136 Calderwood, vol. 7, 353; MacDonald, 158; Todd, 102-103.

137 MacDonald, 165.

138 Stewart, 1036; MacDonald, 164; I. B. Cowan, "The Five Articles of Perth," in Reformation and Revolution, ed. Duncan Shaw (Edinburgh: St. Andrew's Press, 1967), 176.

139 George Abbot, "The Kings Maiesties Letter to the Lords Grace of Canterbury, Touching Preaching, and Preachers (London: s.n., 1622), 3; Lockyer, Britain, 268.

140 Miller, ed., 31; Figgis, 5-8.
} 
straightforward future for his or her kingdom. Few in number, succession-related aristocratic weddings were "weighty" matters (Table 2.4). ${ }^{141}$ This was especially so in Elizabeth's reign because she never married, nor did she name an heir despite many potential successors. ${ }^{142}$ This meant that the succession question was never answered satisfactorily. Historians have agreed that this was why it remained a point of contention. ${ }^{143}$ Other scholars have suggested that although Elizabeth never named an heir, she had made a decision by the late 1580 s. $^{144}$ Statistics from the database support this view as Elizabeth's succession-related intervention occurred steadily in the first three decades of her reign: two in the 1560s, two in the 1570s, one in the 1580s. Furthermore, every succession-related noble marriage involved upper-level nobility, those with close connections to the crown, with the Seymour and Grey families figuring frequently among the transgressors. Nearly all of the marriages were clandestine affairs. The Stuart family, with its links to both the English and Scottish thrones, also posed a threat during Elizabeth's reign as it did during James's.

By 1600, James had been married for eleven years and had two male and two female children. His Scottish and later English successions were, therefore, secured. As a result, only one noble marriage has been connected to the succession during his reign. It simply was not the same issue as it was in Elizabeth's; a fact clearly reflected by the paucity of examples identified in the database. Interestingly, the single succession-related noble marriage that took place in James's reign was during a period in which he still had two living male heirs - a situation of which his great-great uncle Henry VIII could only have dreamt.

Henry VIII's complicated succession had led to numerous wills and parliamentary acts. It was the third Succession Act of 1544 and his 1546 will

\footnotetext{
141 ECW, 63.

142 Some possible candidates for the English throne in 1558 included Frances Grey, duchess of Suffolk, and her daughters Katherine and Mary Grey; Eleanor Clifford, countess of Cumberland, and her daughter Margaret; Margaret Douglas, countess of Lennox; Mary Stuart, queen of Scots; Henry Hastings, third earl of Huntingdon; and Philip II of Spain.

143 Patrick Collinson, This England: Essays on the English Nation and Commonwealth in the Sixteenth Century (Manchester and New York: Manchester University Press, 2011), 61; Ralph Anthony Houlbrooke, James VI and I: Ideas, Authority, and Government (Aldershot: Ashgate, 2006), 25.

${ }^{144}$ Susan Doran and Paulina Kewes, eds., Doubtful and Dangerous: The Question of Succession in Late Elizabethan England (Manchester: Manchester University Press, 2014), 4-5, 20; Janel Mueller, "'To My Very Good Brother the King of Scots': Elizabeth I's Correspondence with James VI and the Question of the Succession," Publications of the Modern Language Association 115 (2000): 1067; Paul E. J. Hammer, "Royal Marriage and the Royal Succession," in A Concise Companion to English Renaissance Literature, ed. Donna B. Hamilton (Oxford: Blackwell Publishing Ltd, 2006), 67.
} 
which safeguarded Elizabeth's smooth ascension to the throne. ${ }^{145}$ The 1544 act returned Elizabeth to the line of succession while also allowing Henry to dispose of the crown as he saw fit. Henry's will ensured that Elizabeth was third in line after her half-siblings, Edward and Mary, if they had no issue. It also anticipated the failure of his direct line and instead settled the succession on the descendants of his younger sister, Mary (the Suffolk line). Thus, it disregarded primogeniture and barred from inheritance the progeny of his elder sister, Margaret (the Stuart line), from which Mary Stuart, queen of Scots, and James VI/I descended.

From the beginning of Elizabeth's reign plays and publications appeared which discussed the succession issue and examined potential candidates for the throne, speculating on their suitability or ineligibility. Playwrights Thomas Norton and Thomas Sackville penned The Tragedy of Gorboduc, a thinly veiled allegorical play which urged the queen to marry, specifically Robert Dudley, later earl of Leicester, and produce heirs to secure the succession. ${ }^{146}$ First performed on stage in 1562 , Gorboduc was later published in 1565, 1570, and again in 1590, attesting to the continuing relevance of the play's principle theme. ${ }^{147}$ John Hales's 1563 Declaration argued against the claims of Margaret Douglas or Mary Stuart in favour of Katherine Grey and the Suffolk line. ${ }^{148}$ Much later, in 1594, co-writers William Allen and Robert Parsons advocated in A Conference about the Next Succession to the Crowne of England, a Catholic successor like King Philip II of Spain or his daughter the Infanta, while John Harington supported James VI in his A Tract on the Succession to the Crown, published in $1602 .{ }^{149}$

Amid many calls to marry or designate an heir, Elizabeth responded to succession questions with silence by invoking the royal prerogative. ${ }^{150}$ This was in part because the 1536 act which had bastardised and disinherited Elizabeth had

\footnotetext{
145 SR, vol. 3, 955-958. See also Susan Doran and Thomas S. Freeman, eds., Mary Tudor: Old and New Perspectives (Basingstoke: Palgrave Macmillan, 2011), 50-51.

146 Thomas Norton and Thomas Sackville, The Tragedie of Gorboduc (London: William Griffith, 1565). See also Henry James and Greg Walker, "The Politics of Gorboduc," EHR 110 (1995): 109-121.

147 E. K. Chambers, The Elizabethan Stage, vol. 4 (Oxford: Clarendon Press, 1923), 80; Laura Estill, "New Contexts for Early Tudor Plays: William Briton, an Early Reader of Gorboduc," Early Theatre 16 (2013): 198.

148 John Hales, “A Declaration of the Succession of the Crowne Imperiall of Ingland, made by J. Hales, 1563," in The Hereditary Right of the Crown of England Asserted (Appendix Numb. 7), ed. George Harbin (London: Printed by G. James, for Richard Smith, 1713), xx-xlii.

149 William Allen and Robert Parsons, A Conference About the Next Succession to the Crown of England Divided into Two Parts (Antwerp: By A. Conincx, 1594); John Harington, A Tract on the Succession to the Crown, ed. Clements R. Markham (London: J. B. Nichols and Sons for the Roxburghe Club, 1880).

${ }^{150}$ ECW, 93-98; Elton, ed., 17-18, 311; Doran, Circle, 222.
} 
not been repealed by the time of her accession in 1558, making her position as monarch precarious. ${ }^{151}$ In addition, as the first decade of Elizabeth's reign closed, her single and heirless state unchanged, the situation became heightened by the Catholic Mary, queen of Scots' 1567 abdication and flight into England in 1568. Mary's threatening presence in heavily-Catholic northern England intensified the already controversial succession question due to her perceived superior claim to the English throne by primogeniture and because she had an established succession in her son, the future James VI. ${ }^{152}$ Elizabeth had support for her decision to invoke the royal prerogative to inhibit succession-related debate. ${ }^{153}$ But, at the same time, her resolution meant that discussion of a topic so central to the stability of the commonweal could no longer take place. ${ }^{154}$

Mary's ominous existence in England had a tremendous effect on the kingdom's commonweal, as did the 1569 Northern Uprising which attempted to place the former Scots queen on the English throne. ${ }^{155}$ As a result, Parliament passed the 1571 Treason Act which declared it unlawful to suggest that anyone other than Elizabeth, operating within the laws and statutes of the land, could determine the succession. ${ }^{156}$ It also banned succession-related writings as treasonous. ${ }^{157}$ According to Howard Nenner, this act meant that "in the matter of the succession, queen-in-parliament was sovereign; and however persuasive the principle of heredity, it was not immutable law."158 The reality was that Elizabeth could disregard primogeniture, opting for wills and statutes like her father had done, or she could respect primogeniture and hereditary right. Either way, she would not be forced into the pronouncement that Parliament desired, remarking

\footnotetext{
151 SR, vol. 3, 655-662.

152 Some Catholic European powers considered Mary Stuart to be the rightful heir to the English throne rather than the "illegitimate" Elizabeth. See Doran and Kewes, eds., 21-22; Retha M. Warnicke, Mary Queen of Scots (London and New York: Routledge, 2006), 52; Marie Axton, The Queen's Two Bodies (London: Royal Historical Society, 1977), 11; Mortimer Levine, The Early Elizabethan Succession Question 1558-1568 (Stanford: Stanford University Press, 1966), 6. 153 Jean-Christophe Mayer, ed., Breaking the Silence on the Succession: A Sourcebook of Manuscripts and Rare Elizabethan Texts (c. 1587-1603) (Montpellier: Université Paul-Valéry Montpellier 3, 2003), 29-35.

154 Hartley, ed., vol. 1, 154.

155 Stephen Alford, The Early Elizabethan Polity: William Cecil and the British Succession Crisis, 1558-1569 (Cambridge: Cambridge University Press, 1998), 1. See also BL, Cotton MSS, Caligula C/I fol. 456.

156 SR, vol. IV, 526-528.

157 Mayer, ed., Breaking the Silence, 7, 10.

158 Howard Nenner, The Right to be King: The Succession to the Crown of England, 1603-1714 (Basingstoke: Macmillan Press Ltd, 1995), 14.
} 
that "I have always abhorred to draw in question the title of the crown.... they shall succeed that has most right."159 But who was that person?

In what ultimately became an eighteen-year-long house arrest, Mary Stuart's exile in England made the succession question inescapable and has influenced modern research on the topic. Since the early 1990s historians have separated succession studies into two phases: pre-1587 and post-1587, a division which arose from Patrick Collinson's "The Elizabethan Exclusion Crisis and the Elizabethan Polity."160 In it, Collinson, building on Hurstfield's earlier work, highlighted the ruling elite's political need to prevent the succession of the Catholic Mary, queen of Scots, for the preservation of Protestantism. ${ }^{161}$ This necessity disappeared after Mary's execution in 1587, but Elizabeth's successor remained unclear as multiple candidates could assume the crown, each supported or disputed for various reasons including legitimacy, religion, sex, or nationality. ${ }^{162}$ Current historians like Doran, Paulina Kewes, and Simon Adams, for example, have argued that while James's accession to the English throne was never an obvious or foregone conclusion, Elizabeth herself had already decided by whom she would be followed by the late 1580s. ${ }^{163}$ Evidence for her preference for the Stuart line appeared as early as 1561 while the queen was in discussions with the Scottish ambassador, William Maitland, laird of Lethington. Lethington reported that "in her [Elizabeth's] own judgment she liked better of the queen of Scotland's title next herself than of all others; and failing of her own issue, could best be content that she should succeed."164 Privately expressed to Lethington though never formally

\footnotetext{
${ }^{159}$ ECW, 65. See also, Mayer, ed., Breaking the Silence, 19-20.

160 Collinson, This England, 61-97. This essay originally appeared in print in 1994, following Collinson's 1993 lecture. Scholarly works which have addressed the early Elizabethan succession question include Alford, Early Elizabethan Polity; Levine, Early Elizabethan Succession Question. Late Elizabethan succession has been discussed in numerous volumes including Doran and Kewes, eds. Doubtful and Dangerous; Jean-Christophe Mayer, ed., The Struggle for the Succession in Late Elizabethan England: Politics, Polemics and Cultural Representations, with a preface by Jenny Wormald (Montpellier: Institut de Recherche sur la Renaissance, 2004); Nenner, The Right to be King.

161 Collinson, This England, 61; Joel Hurstfield, Freedom, Corruption and Government in Elizabethan England (London: J. Cape, 1973), 104-134.

162 After 1587, possible candidates for the English throne included the sons of Lady Katherine Grey, Edward and Thomas (deemed illegitimate); Lady Arbella Stuart (female, Stuart line barred from the English crown by Henry VIII's will); Philip II of Spain (foreign [Spanish], Catholic); Infanta Isabella Clara Eugenia (foreign [Spanish], Catholic, female); James VI (foreign [Scottish], Stuart line barred); Lady Margaret Clifford (Suffolk line); Ferdinando Stanley, lord Strange (crypto-Catholic [died 1594]); Henry Hastings, third earl of Huntingdon (descended from Edward III, not the Tudor line [died 1595]); Charles Neville, sixth earl of Westmorland (descended from Edward III, attainted, Catholic, living overseas [died 1601]); and Alexander Farnese, duke of Parma (foreign [Spanish], Catholic).

163 Doran and Kewes, eds., 4-5; Simon Adams, "The Succession and Foreign Policy," History Today 53 (2003): 45; John Guy, ed., The Reign of Elizabeth I: Courtand Culture in the Last Decade (Cambridge: Cambridge University Press, 1995), 17.

${ }^{164} E C W, 67$.
} 
declared, Elizabeth's inclination towards the Stuarts was also made manifest in her reaction to and involvement in succession-related marriages, as described in chapter five.

Though Elizabeth indicated a partiality for the Stuart line, James VI's claim was by no means definitive. ${ }^{165}$ As Nenner explains, there could be found as much justification for his claim as against it: "As a political matter, James may have been the likely successor to Elizabeth, but as a constitutional matter it was far from certain whether he had the only right, or even the best right". ${ }^{166}$ What is more, the previously mentioned Treason Act and the subsequent 1584 Act for the Queen's Surety, which sought to preserve the queen's safety against plots and potential assassination, had been specifically aimed at Mary to prevent her from inheriting the English crown. ${ }^{167}$ Accordingly, both acts tainted James's right because, as contemporaries observed, since he "pretendeth all his right to the crown of England by his said mother, [he] can have none at all."168

Numerous letters between Elizabeth and James, which shed light on the succession, remain. ${ }^{169}$ It was a correspondence which the queen herself initiated in 1585 during discussions of an Anglo-Scottish alliance. As Janel Mueller has suggested, Elizabeth's opening of communication with James may have been prompted by the closure of her final opportunity at marriage and could be interpreted as an indication that James was her preferred choice of successor. ${ }^{170}$ With the execution of Mary, queen of Scots, in 1587, James wrote to Elizabeth, seeking redress in the form of an official designation as her heir: "I look that ye will give me at this time such a full satisfaction in all respects as shall be a mean to strengthen and unite this isle, establish and maintain the true religion." 171 The queen refused. Not to be deterred, by the mid-1590s James was directing his efforts towards the pursuit of the English throne by pacifying the chaotic Borders region and supplying Scottish troops to aid English forces in Ireland. ${ }^{172} \mathrm{He}$ also

\footnotetext{
165 Mayer, ed., Breaking the Silence, 14.

166 Nenner, 13.

167 SR, vol. 4, 704-705.

168 Allen and Parsons, Part 2, 117; Mayer, ed., Breaking the Silence, 88; Nenner, 15.

169 See, for example, Queen Elizabeth I and King James VI, Letters of Queen Elizabeth and James VI of Scotland, ed. John Bruce (London: J. B. Nichols and Son, 1849), 51-52, 134-135; ECW, 263-266, 297, 355-356; LKJ,65-66, 84-85.

170 Mueller, 1065, 1066-1068, 1071.

${ }^{171}$ LKJ, 84-85.

172 Anna Groundwater, "He 'made them friends in his cabinet': James VI's Suppression of the Scott-Ker Feud," in James

VI and Noble Power in Scotland 1578-1603, ed. Miles Kerr-Peterson and Steven J. Reid (London and New York:
} 
sought support for his claim from the king of France. ${ }^{173}$ On 24 March 1603, as yet unaware of Elizabeth's death, James wrote, “God as my witness, it never was, nor shall be my intention to enter that kingdom in any other sort but as the son and righteous heir of England, with all peace and calmness and without any kind of alteration in state or government as far as possible I can." 174 Shortly to be revealed were the validation of his claim and a peaceful transition to the English throne. From that point, James shifted his succession focus to the dynastic marriages of his surviving children. Only once did a succession-related noble marriage impact his reign and this was at the event of his cousin's clandestine marriage in 1610, discussed in chapter five.

\section{Anglo-Scottish union}

Shown in Table 2.4, more than half of policy-related marriages in which James participated joined English and Scottish nobility. As the creation of Britain was of great personal importance to James, it is understandable that these marriages take up such a large percentage of his overall policy-related marriage involvement. No Anglo-Scottish-linked marriages have been recorded in the database for Elizabeth's reign when the union of England and Scotland was less realistic. The exiled Mary Stuart, who lived under house arrest in northern England from 1568 to 1587, figured largely in the fragile relations between the two states.

Many sixteenth- and seventeenth-century writers like John Mair, James Henrisoun, and John Gordon, saw similarities between England and Scotland. ${ }^{175}$ As Bishop John Aylmer expressed in 1559, the joining of the two kingdoms would be the natural result of commonalities like religion, culture, and language:

Routledge, 2017), 110-111; Alexander Courtney, "The Scottish King and the English Court: The Secret Correspondence of James VI, 1601-3," in Doubtful and Dangerous: The Question of Succession in Late Elizabethan England, ed. Susan Doran and Paulina Kewes (Manchester: Manchester University Press, 2014), 140-141.

173 CP, Vol. 109/91; Newton, 918.

174 LKJ, 206-207.

175 John Mair [Major], A History of Greater Britain as well England as Scotland, trans. and ed. Archibald Constable (Edinburgh: Printed at the University Press for T. and A. Constable, 1892), 42; James Henrisoun [Harrison], An Exhortacion to the Scottes to Conforme Them Selfes to the Honorable, Expedie[n]t, and Godly Vnion, Betwene the Twoo Realmes of Englande and Scotlande (London: Richard Grafton, 1547); Edward Seymour, Duke of Somerset, An Epistle or Exhortation to Unity and Peace (London: Richard Grafton, 1548); John Gordon, The Union of Great Britaine (London: Printed [by G. Eld] for William Aspley, 1604). See also Bruce R. Galloway and Brian P. Levack, eds., The Jacobean Union: Six Tracts of 1604 (Edinburgh: Clark Constable for the Scottish History Society, 1985); Roger A. Mason, ed., Scotland and England 1286-1815 (Edinburgh: John Donald Publishers Ltd, 1987), 65-70, 85-112. 
Some translation and joining of realms may turn to much good, and the wealth and tranquillity of many... to have united both realms in dominion, regiment and law, as they be in nature, language, and manners... It is religion and likeness of manners, that join men together... Where there is one faith, one baptism, and one Christ there is narrower fraternity then, if they came out of one womb. ${ }^{176}$

Like Aylmer, James wrote of the connections between the kingdoms-the "nearness of blood... vicinity of realms, conformity of language, and religion"which was echoed by numerous pro-union pamphlet writers during his reign of England. ${ }^{177}$ Several anonymously composed anti-union tracts also appeared though these specifically argued against the unification of laws between the two countries. ${ }^{178}$ Even so, due to his parentage James considered himself the physical embodiment of a union between Scotland and England; a sentiment which also resonated deeply with his religious sense: "God has joined the right of both the kingdoms in my person, so ye may be joined in wealth, in religion, in hearts and affections." 179 As Gordon suggested, the king's role in the unification of the two kingdoms made him a "successor unto Constantine"-one fated to guide all Protestants, not only in Britain but also on the continent, towards a united Christendom. ${ }^{180}$

Enveloping religion and succession, an Anglo-Scottish union had been sought for centuries through dynastic marriage as was typical of European monarchs. ${ }^{181}$ Royal and noble marital unions between England and Scotland occurred frequently in the relative peace of the thirteenth century. ${ }^{182}$ Later, Henry

176 Aylmer, fols. L3v-M1r. See also McLaren, 259; Bruce Galloway, The Union of England and Scotland 1603-1608 (Edinburgh: John Donald Publishers Ltd, 1986), 7.

177 LKJ, 69. See also, for example, John Skinner, Rapta Tatio, The Mirruor of his Majesties Present Government, Tending to the Union of his Whole Iland of Brittonie Martiall (London, Printed by W. W[hite] for S. Waterson, 1604); Francis Bacon, $A$ Brief Discourse, Touching the Happie Vnion of the Kingdomes of England, and Scotland (London: Printed [by R. Read] for Fœlix Norton, 1603); William Cornwallis, The Miraculous and Happie Vnion of England \& Scotland (Edinburgh: Printed by Thomas Finlason, 1604).

178 TNA, SP 14/7/83-97, 153, 165-172; ibid, SP 14/9A/83-112.

$179 R P C, 1603-1604,558$ n.

180 Gordon, Union, 6. See also Sybil M. Jack, "National Identities within Britain and the Proposed Union in 1603-1607," Parergon 18 (2001): 86; Allan I. Macinnes, "Regal Union for Britain, 1603-38," in The New British History: Founding a Modern State, 1603-1715, ed. Glenn Burgess (London and New York: I. B. Tauris Publishers, 1999), 35.

181 J. H. Elliott, Scots and Catalans, Union and Disunion (New Haven and London: Yale University Press, 2018), 7.

182 These marriages included King Alexander II of Scotland to Joan, daughter of King John of England in 1221; King Alexander III of Scotland to Margaret, daughter of King Henry III of England in 1251; and the planned marriage of Edward, prince of Wales and son of King Edward I of England, to Margaret, "maid of Norway," granddaughter of Alexander III in 1290. In addition, Alexander II's sister Princess Isabella married English nobleman Roger Bigod, earl of Norfolk, in 1225, while Princess Margaret (also called Marjorie) married English nobleman Gilbert Marshal, earl of Pembroke, in 1235. Another Anglo-Scottish wedding took place in London between the hostage James I of Scotland to Joan Beaufort, daughter of John, first earl of Somerset, in 1424. 
VII of England's attempt at amity, albeit short-lived, with his northern neighbour culminated in another royal Anglo-Scottish marriage: that of Margaret Tudor, his daughter, to James IV of Scotland in 1503.183 Forty years later, Henry VIII's proposed marriage between then Prince Edward, later Edward VI, and Mary Stuart, later queen of Scots, was part of the Treaty of Greenwich which sought to unite the two kingdoms. ${ }^{184}$ Historian Bruce Galloway has commented that "English ambitions in Scotland were to be achieved by peaceful means."185 But lack of support for the treaty in Scotland angered Henry and led to eight years of war between England and Scotland known as the "Rough Wooing." According to Marcus Merriman, the Rough Wooing taught both sides that peaceful "collaboration was the best path for future relations;" one which "could not successfully be forced." 186 Though lack of heirs from earlier unions had prevented any lasting connection between England and Scotland, Margaret Tudor's grandson, James VI, would become James I of England in what was to be a calm succession, thereby linking the two kingdoms under a single crown.

Long before James's accession, Elizabeth, like her forebears, saw dynastic marriage as a means of unifying England and Scotland and in 1560 two AngloScottish dynastic marriages were proposed. A marriage between James Hamilton, third earl of Arran and heir presumptive to the Scottish throne, and Elizabeth was mooted while the queen's government, as an alternative, encouraged the wedding between Arran and her heir, Lady Katherine Grey, discussed below. ${ }^{187}$ Though neither proposal was successful, it signalled the important role of dynastic marriage in realising an Anglo-Scottish union and the belief that marriage was an appropriate way to establish it. This belief became especially apparent when the widowed Mary Stuart returned to Scotland to claim her throne in August 1561. Not long after Mary's return, Elizabeth proposed as a possible consort "some noble man of good birth being naturally borne to love this Isle;" Robert Dudley, the

${ }^{183}$ Calendar of Documents Relating to Scotland, ed. Joseph Bain, vol. 4 (Edinburgh: H. M. General House, 1888), 339-340; Elliott, 15.

${ }^{184}$ Letters and Papers, vol. 18/1, 454-457. After Edward VI's accession, a marriage between the young king and Mary, queen of Scots, was again suggested. See HMC, Salisbury, vol. 1, 59.

185 Galloway, 9.

186 M. H. Merriman, "The Assured Scots: Scottish Collaborators with England during the Rough Wooing," SHR 47 (1968): 34.

187 RPS, A1560/8/7. 
newly-elevated earl of Leicester, in particular. ${ }^{188}$ Mary declined the options since Elizabeth refused to confer the English succession upon her, with one contemporary noting that if only the two queens could marry,

Me-thinketh it were to be wished of all wise men and her Majesty's good subjects, that the one of those two Queens of the isle of Britain were transformed into the shape of a man, to make so happy a marriage, as thereby there might be an unity of the whole isle. ${ }^{189}$

As each proposal failed, the belief that an Anglo-Scottish union might be attained through a dynastic marriage that Elizabeth could control diminished. The lack of union-related noble marriages recorded in the database during Elizabeth's reign attests to this. As a result, and as Roger Mason has asserted, the Elizabethan Anglo-Scottish policy, if it existed, was one of "short-term measures, pursued at minimal expense, aimed at defending her [Elizabeth's] own dynastic rights and securing England's northern frontier."190

Though Elizabeth became generally "unmoved" by any unification plans, ${ }^{191}$ in 1584 James sent an ambassador to London to seek Elizabeth's support for an Anglo-Scottish union. ${ }^{192}$ To combat the Spanish threat, discussions were held for the creation of a religious-based military coalition between England, Scotland, and other Protestant states. James wrote to the queen that "the league shall be offensive and defensive for all invasions upon whatsomever pretext...I will employ my crown and country to resist to whatsomever invasions upon yours." 193 Founded on a shared Protestant faith, James felt the coalition was also a suitable beginning to a more formalised Anglo-Scottish union. He expressed as much once the official Treaty of Berwick was drawn up in 1586: "The articles of a new treaty and league... we like well of, and thinks them fittest and most likely grounds for our mutual sureties to be built on." ${ }^{194}$ Yet relations between the two kingdoms

\footnotetext{
188 TNA, SP 52/8/157; ibid, SP 52/9/130.

189 Joseph Stevenson, ed., Selections from Unpublished Manuscripts in the College Arms and the British Museum Illustrating the Reign of Mary Queen of Scotland, 1543-1568 (Glasgow: s.n., 1837), 84; McLaren, 259. See also TNA, SP 52/9/196-198; Warnicke, Mary, Queen of Scots, 98.

190 Roger A. Mason, "Scotland, Elizabethan England and the Idea of Britain,” TRHS 14 (2004): 287.

191 Mason, "Idea of Britain," 287.

192 LKJ, 59. See also TNA, SP 52/40/99-100.

193 LKJ, 66. See also RPS, 1585/12/28.

194 LKJ, 63.
} 
were deeply harmed by Mary's execution in England one year later. ${ }^{195}$ Following the death of the king's mother, an act of the Scottish Parliament forbade Scots living along the Borders to marry English subjects. ${ }^{196}$ This act was later repealed when James assumed the English crown. ${ }^{197}$

The creation of Britain through a ratified Anglo-Scottish union became central to James's reign upon his accession to the English throne in 1603, and he began his rule with great ambitions; ambitions which lessened over time. ${ }^{198}$ While many historians have explored the complex relationship between England and Scotland and the protracted union of the two kingdoms, Galloway's The Union of England and Scotland, 1603-1607, specifically examined the beginnings of the union project in the early years of James's reign of England. ${ }^{199}$ Due to initial "resentment and diplomatic manoeuvring" against the union project, the king issued in 1604 a royal proclamation to "assume ... the name and style of King of Great Britain, including therein according to the truth, the whole island." 200 Though meant to unite the public, the proclamation, according to Russell, was deeply problematic for legal reasons that the king neither anticipated nor fully understood.201 Furthermore, as Wormald found, many among the English were suspicious of the king's desire to create Britain while the Scots also had their doubts as to what type of role their country would play in such a union. ${ }^{202}$ Neither kingdom wanted to be side-lined or subordinated to the other; that was never James's intention. $^{203}$ By 1607, James's vision of Britain had been completely defeated in the English Parliament and he abandoned his plans. ${ }^{204}$ His union project unrealised, James did achieve some successes towards unifying his

\footnotetext{
195 Susan Doran, "Revenge her Foul and Most Unnatural Murder? The Impact of Mary Stewart's Execution on AngloScottish Relations," History 85 (2000): 589-612. 196 RPS, 1587/7/70.

197 SR, vol. 4, 1134-1137.

198 Jenny Wormald, “'A Union of Hearts and Minds?' The Making of the Union Between Scotland and England, 1603," Revista Internacional de los Estudios Vascos 5 (2009): 122.

199 T. C. Smout, ed., Anglo-Scottish Relations from 1603 to 1900 (Oxford: Oxford University Press for the British Academy, 2005); Mason, ed., Scotland and England 1285-1815; William Ferguson, Scotland's Relations with England: A Survey to 1707(Edinburgh: Donald, 1977).

200 Galloway, 59; Larkin and Hughes, eds., 96.

201 Russell, James, 66; Galloway, 60. See also Peck, ed., 52-54.

202 Jenny Wormald, "The Creation of Britain: Multiple Kingdoms or Core and Colonies?," TRHS, 6th ser., vol. 2 (Cambridge: Cambridge University Press, 1992), 186.

203 Peck, ed., 53.

204 Russell, James, 73; Wormald, “'Union of Hearts and Minds,"' 122
} 
kingdoms such as free trade, naturalisation, the repeal of all hostile laws, and a unified diplomatic service for the two countries. ${ }^{205}$

As noted, James used the royal prerogative to promote union after the 1607 failure in Parliament by encouraging intermarriage between his Scots and English nobility. This was the king's "Briticisation" policy-a purposeful establishment and growth of Britain through Anglo-Scottish marital alliances and the resulting progeny. Elaborate theatrical productions which emphasised unification were often part of Anglo-Scottish marriage celebrations held at court. Though delivering an astute political assessment of the union project, Galloway gave Anglo-Scottish marriages, a focus of this thesis, only a brief mention. ${ }^{206}$ Peck and Croft have commented more extensively on James's active management of marriages between his English and Scottish nobility and courtiers, ${ }^{207}$ while Brown and Brian Levack, in their assessments of James's promotion of Anglo-Scottish marriages, have determined that they did little to bring the two countries together culturally. ${ }^{208}$

Union-focussed scholarship concerning literature, theatre, and masques of the Jacobean period has influenced this thesis's interpretation of Anglo-Scottish noble marriages. ${ }^{209}$ David Lindley's research has traced the politics and meaning behind masques performed at Anglo-Scottish court weddings, noting the presentation of idealistic love and union alongside fears and challenges inherent to a English and Scottish unification. ${ }^{210}$ Alternatively, Marie Loughlin's analysis of court masques by Ben Jonson and Thomas Campion, which hailed Anglo-Scottish marriages, has focussed on the symbolism of the body within the context of the union project, a theme underscored by James himself. ${ }^{211}$ Providing a different viewpoint, Lori Anne Ferrell's studies have drawn on sermons preached at Anglo-

\footnotetext{
205 SR, vol. 4, 1134-1137. See also Wormald, “James VI \& I,” History Today 52 (2002): 31.

206 Galloway, 166.

207 Peck, Court Patronage, 71; Croft, King James, 66-67.

208 Levack, 186-187; Brown, "Scottish Aristocracy," 569-575; idem, Kingdom or Province, 46-47.

${ }^{209}$ See, for example, Kevin Curran, Marriage, Performance, and Politics at the Jacobean Court (Farnham: Ashgate, 2009); David Bevington and Peter Holbrook, eds., The Politics of the Stuart Court Masque (Cambridge and New York: Cambridge University Press, 1998); J. R. Mulryne and Margaret Shewring, eds., Theatre and Government under the Early Stuarts (Cambridge: Cambridge University Press, 1993); David Lindley, ed., The Court Masque (Manchester: Manchester University Press, 1984); Stephen Orgel, The Illusion of Power: Political Theatre in the Renaissance (Berkeley: University of California Press, 1975).

210 David Lindley, “Campion's 'Lord Hay's Masque' and Anglo-Scottish Union,” Huntington Library Quarterly 43 (1979): 1-11. See also, idem, "Who Paid for Campion's 'Lord Hay's Masque'?" Notes and Queries 26 (1979): 144-145; idem, "Embarrassing Ben: The Masques for Frances Howard," English Literary Renaissance 16 (1986): 343-359.

211 Marie H. Loughlin, "Love's Friend and Stranger to Virginitie': The Politics of the Virginal Body in Ben Jonson's Hymenaei and Thomas Campion's The Lord Hay's Masque," ELH 63 (1996): 833-849. See also, JPW, 132-136.
} 
Scottish weddings, interpreting the political messages of those marriages within a religious context. ${ }^{212}$ Moreover, building on the work of historians like Galloway and Levack as well as Ferrell and Loughlin, Kevin Curran has investigated the political rhetoric and propaganda elicited by masques performed at Anglo-Scottish court weddings, specifically in relation to the literal and figurative union of bride and groom, England and Scotland.213 Addressed in chapter three, Anglo-Scottish marriages provided James with the prospect of connecting closely with his nobility as he continued to promulgate unification ideas.

\section{Arran-Grey, 1560}

Elizabeth's religion, succession, and Anglo-Scottish union agendas converged in the proposed Arran-Grey marriage of 1560. This match has not been included in the database since it did not transpire. It, nonetheless, epitomises the opportunities a single noble marriage might provide to a monarch in terms of implementing policies.

In the 1540 s the failure of two proposed dynastic marriages, ${ }^{214}$ followed by the "Rough Wooing,"215 made an alliance between England and Scotland seem unattainable. After Elizabeth ascended the throne in 1558, her marriage to an heir to the Scottish crown was put forward. It would be a way for England and Scotland to achieve "amity," should "the Queen... marry the [James Hamilton, third] Earl of Arran."216 At the time Elizabeth was involved in other marriages negotiations with the Swedish Prince Eric, later King Eric XIV, and Charles II, archduke of Austria, as well as open flirtations with the earl of Leicester. ${ }^{217}$ So, instead of her own marital

\footnotetext{
212 Lori Anne Ferrell, "The Sacred, the Profane, and the Union: Politics of Sermon and Masque at the Court Wedding of Lord and Lady Hay," in Politics, Religion, and Popularity in Early Stuart Britain, ed. Thomas Cogswell, Richard Cust, and Peter Lake (Cambridge: Cambridge University Press, 2002), 45- 64.

213 Kevin Curran, "Erotic Policy: King James, Thomas Campion, and the Rhetoric of Anglo-Scottish Marriage," Journal for Early Modern Cultural Studies 7 (2007): 55-77; idem, Marriage, Performance, and Politics, passim.

${ }^{214}$ Henry VIII proposed two dynastic marriages. The first was between Prince Edward, later Edward VI, and Mary Stuart, queen of Scots. See RPS, A1543/3/2; ibid, A1546/6/15; Letters and Papers, Foreign and Domestic, of the Reign of Henry VIII, ed. James Gairdner and R. H. Brodie, vol. 18/1, 454-457. The second dynastic marriage was to join Lady Elizabeth, later Queen Elizabeth I, to James Hamilton, master of Hamilton, later third earl of Arran. See Letters and Papers, vol. 18/1, 214; John Durkan, "James, Third Earl of Arran: The Hidden Years," SHR 65 (1986): 166. Hamilton was descended from King James II of Scotland. As Mary, queen of Scots's cousin, he was second-in-line for the throne after his father, James Hamilton, duke of Châtellerault.

215 See Marcus Merriman, The Rough Wooings: Mary Queen of Scots, 1542-1551 (East Lothian: Tuckwell Press, 2000).

216 TNA, SP 52/3/110; RPS, A1560/8/7. See also HMC, Salisbury, vol. 1, 157.

217 CSPF, 1560-1561, 273. Also occurring close to this time was the sudden, mysterious death of Leicester's wife, Amy Robsart, on 8 September 1560.
} 
alliance with Arran, she recommended that the Scottish earl be matched with Lady Katherine Grey, her cousin and presumed heir:

her Council seeing how necessary the amity of Scotland is to her [Elizabeth], intend to offer to Arran in marriage the Lady Catherine, daughter to the late Duchess of Suffolk, that she being an heir apparent and next of blood to the crown of England, shall be matched with an heir apparent of Scotland; so if both the present possessors of these crowns die without succession, the right shall come to them two.

The projected Arran-Grey union was an early example of Elizabeth's application of her in loco parentis right to manage the marriage possibilities and negotiations of her maid of honour, Lady Katherine. Simultaneously, in calling for an Arran-Grey marriage, the queen engaged the royal prerogative. Determining foreign policy was the queen's exclusive remit and the Arran-Grey alliance served as a foreign relations manoeuvre for improving English-Scottish relations.

Acting in the roles of monarch and parent, Elizabeth saw the many potentialities an Arran-Grey union presented. It would have joined Protestants of royal blood of England and Scotland, bringing religious uniformity to both countries while effecting a solidly Protestant future for both kingdoms. It would have strengthened diplomatic ties by creating an Anglo-Scottish union that would end French influence in Scotland. The Arran-Grey marriage might also have provided for the succession should anything happen to Elizabeth. ${ }^{218}$ In light of Parliament's calls for her to marry or at least name a successor, the Arran-Grey proposed marriage transferred the succession spotlight to Lady Katherine, providing Elizabeth with some temporary relief from its glare. But, at the same time, Elizabeth's suggestion of Lady Katherine as a mate for Arran further increased the latter's stature in the succession debate which was perhaps an unintended consequence.

The Lords of Scotland visited Elizabeth's court in October 1560 "to treat of marriage" but nothing more of the Arran-Grey proposed marriage was heard. ${ }^{219}$ The match was not furthered probably because of the 5 December 1560 death of King François II of France, Mary, queen of Scots's husband. This event was quickly followed by Elizabeth's own formal rejection of the Arran marriage proposal on 8 
December. ${ }^{220}$ Left free to bid for Mary's hand, Arran and the Lords of Scotland pursued the earl's marriage to the newly widowed queen at least by early January 1561.221 Although the Arran-Grey proposition was fruitless, it showed that Elizabeth clearly understood and wished to benefit from Lady Katherine's importance within the marriage market. The proposed match would have linked the queen's goals of upholding the Protestant religion, securing the succession, and establishing an Anglo-Scottish union, policies of top priority for the assurance of peace and stability throughout the island.

\section{Conclusion}

The Lindsay-Lyon marriage described at this chapter's opening exemplified the opportunities a single noble marital alliance offered a monarch. These opportunities included exerting royal authority through plural prerogative of widows' marriages and in loco parentis duty, establishing a stabilising patron-client relationship, and fostering peace. This chapter has also shown that the practice of noble-marriage management brought together many different features of the early modern monarchy in England and Scotland: hierarchy and patronage, prerogatives and law, courts and political agendas concerning religion, succession, and Anglo-Scottish union. With so much at stake, the oversight of marriages was an important aspect of monarchy, one that has been largely neglected by scholars. What has also been overlooked is each monarch's keen understanding and recognition of the lateral bonds that marriages created between families; bonds that had the potential to destroy the hierarchy upon which Elizabeth's and James's power rested. Their patronage of couples who represented adjoining kin groups sought to direct burgeoning loyalties to the crown. Subsequent chapters will place Elizabeth's and James's handling of noble marriages within the context of other scholarly works which highlight the role of the nobility within a monarchy. ${ }^{222}$ The chapters will also examine how both monarchs' management of marriages underlined the importance of strong monarch-noble bonds, crown privileges and

220 Calendar of the State Papers, Relating to Scotland, ed. Markham John Thorpe, vol. 1 (London: Longman, Brown, Green, Longmans, and Roberts, 1858), 165.

221 TNA, SP 70/22/42.

222 See, for example, Kerr-Peterson and Reid, eds., 2-3; Brown, Noble Power, 2; Bernard, 44-45; Guy, ed., Tudor

Monarchy, 2; Hartley, 6; Peck, “Jacobean Dilemma," 27-28; Croft, King James, 31; Elton, ed., 247; Stone, Crisis, 64. 
patronage, and the maintenance of royal authority within the hierarchical system of monarchy. 


\section{Chapter 3}

\section{"Fêtes and banquets": monarchical support for noble marriages ${ }^{1}$}

On 27 December 1604, the Jacobean court gathered at Whitehall to celebrate the marriage of one of King James VI and I's English favourites and gentlemen of his privy chamber, Sir Philip Herbert, to Susan de Vere, daughter of Edward, seventeenth earl of Oxford. The bride, honoured to be escorted to the church by Prince Henry and the duke of Holst and with Queen Anne following, met her groom at the King's Chapel at Whitehall where they were married in the king's presence, James giving away the bride himself. ${ }^{2}$ Lady Susan, in her "Tresses and Trinkets... became her self so well," causing James to exclaim that "if he were unmarried he would not give her, but keep her himself!" ${ }^{3}$ This auspicious beginning led to a wedding banquet in the "great Chamber" and a masque performed by noblemen and gentlemen of the court in the "Hall." The newlyweds spent their wedding night in the "Council Chamber," during which time the king visited them "in his Shirt and Night-Gown." But what made it a "good Marriage" was not only the expensive presents of plate and other gifts from the guests "valued at 2,500l", but also "a Gift of the King's of 500l. Land for the Bride's Jointure." 4 The king's offering was a gesture of acceptance and approval of the Herbert-Vere union, a sign of his intimacy with and protection of the couple, and the establishment of what would hopefully become a mutually-beneficial patronclient relationship. A further mark of regal endorsement had been James's giving away of the bride. This act signified his divine, hierarchical, and patriarchal roles in the marriage as God's representative, king, and father-figure, along with the couples' inferred obedience and loyalty to him.

The Herbert-Vere marriage exemplifies James's supportive involvement in noble weddings. Patronage, sourced from crown assets, allowed James to solidify

\footnotetext{
${ }^{1}$ CSPV, 1603-1607, 308.

2 Winwood, vol. 2, 43; Nichols, James, vol. 1, 469-470. Sir Philip was the son of the second earl of Pembroke. He would be elevated to the peerage as the earl of Montgomery in 1605, and later become the fourth earl of Pembroke.

3 Rimbault, ed., 160.

${ }^{4}$ Winwood, vol. 2, 43.
} 
his relationship with Herbert, who was elevated to the peerage one year later, and to create a strong tie with the couple. In fulfilling his in loco parentis duty for Sir Philip, a member of his household, the king also took advantage of the opportunity that the marriage provided to broadcast a wider message to his court. The Herbert-Vere wedding took place in a climate of division between Scots and English courtiers, where Scots assumed the majority of the most intimate and lucrative posts in the royal household and the English complained of partiality and exclusion. 5 As a result, the wedding gave James the chance to honour an English couple and their kin, the influential Herberts and Veres, of whom Salisbury was a member, and to unite new familial loyalties with the crown. The king's approbation represented an embrace of all his English courtiers and, in a broader sense, his English subjects, while it also highlighted the need for allegiance and compliance. James's enthusiastic participation and support, personal and financial, reveals how important noble marriages were for his kingship.

As the above example demonstrates, noble marriages could be personally and highly celebrated by the monarch. This overt celebration was a gift that publicly recognised the alliance of two families, was formalised through patronage of the couple, and implied trust and obedience. This chapter contends that the gift of Elizabeth's or James's personal and public support of weddings was a purposeful, focussed strategy of the monarch which offered occasions to advance royal authority, constructively manage noble relations, and extend crown policies-all of which was achieved through patronage. It illustrates how both monarchs openly supported various marriages, for what reasons, and the effects. Kettering, in explaining patronage in sixteenth-century France, has stated that "there were no formal ceremonial celebrations of the patron-client bond." 6 However, the case studies in this chapter will indicate that monarchical patronage in England and Scotland, at least relative to noble marriages, was different. In fact, a chief way Elizabeth or James displayed encouragement, consent, and initiation of patronage was by granting couples and their joining families the gift of their personal and public appearance at marriage ceremonies or celebrations.

\footnotetext{
5 Neil Cuddy, "Anglo-Scottish Union and the Court of James I, 1603-1625," TRHS, 5th ser., 39 (1989): 111-112; Croft, King James, 57-58; Lockyer, Britain, 256; Thomas Rymer, Acta Regia (London: Printed for James, John and Paul Knapton, et al., 1734?), 511.

${ }^{6}$ Kettering, "Gift-giving," 146.
} 
So why was the monarch's acknowledgment and patronage of a noble wedding important and how did it alter any pre-existing patron-client bonds? Because the early modern monarchy was a hierarchical system, the king or queen held the dominant position at the apex of a pyramid of relationships. McCormack's research has shown that hierarchies, like patron-client relationships, are "asymmetric" and consist of relationships "between two actors, one of which is more powerful than the other."7 The vertically-oriented connections in a hierarchy which linked directly to the monarch perpetuated his or her dominant position. Conversely, lateral connections, as in marriages between subordinate groups like noble families, might weaken the crown. Ferguson has highlighted that in a hierarchical system "The key is to always add nodes [connections] downwards, but never connect nodes laterally" as too many lateral bonds "can destroy the ruling node [monarch]." 8 Thus, it was essential that monarchs like Elizabeth and James acknowledge certain newly-established lateral connections that marriages created, particularly those among the powerful, upper-level nobility (Table 3.1) Indeed, Heal has noted that women were "at the heart of the gift-exchange system" because they "sealed the bond" amid families at a marriage. The wedding ceremony provided "the opportunity to give from one family to another" thereby creating a reciprocal bond and commitment between them. ${ }^{9}$ By recognising and supporting marriages, Elizabeth and James not only reinforced any individual, pre-existing patron-client ties but they also established new patronage connections with couples who represented their recently-united families. In doing so, both monarchs endeavoured to re-direct families' allegiances and obligations from each other back to the crown. This chapter is the first of three which will connect statistics and trends collected from the database with expository cases of Elizabeth's and James's management practices. The tables presented below separate both monarchs' supportive participation in marriages from their overall marriage involvement. Significantly, the statistics uncover that, contrary to Stone's evaluation, Elizabeth's involvement in noble marriages was both largely positive and active. Database evaluation also exposes the connections between public support of marriages and the duration of patron-client bonds. Moreover, the data

\footnotetext{
7 McCormack, 7.

8 Ferguson, 39-40.

${ }^{9}$ Heal, 57.
} 
show how advocacy for certain weddings sometimes linked to Elizabeth's or James's crown policies relating to religion or Anglo-Scottish union.

While illuminating the database findings, the following Elizabethan and Jacobean case studies also highlight the importance of prerogatives, plural and the royal, in the handling of alliances. As described in chapter two, prerogatives conferred monarchs' rights to interpose themselves in marriages and were the foundation upon which Elizabeth and James built patron-client relationships. Moreover, the royal prerogative encompassed the "secret of government" or mysteries of state which permitted the monarch's independent action. ${ }^{10}$ Also mentioned in chapter two, a "'zone of silence"' surrounded the royal prerogative and this chapter will examine how Elizabeth and James used that silence to forward unwritten policies. The examples below support Barrow's research cited in the introduction, which highlights the symbolism of gift-giving which implied the initiation of a patron-client relationship, and the importance of patronage for solidifying social connections. ${ }^{11}$ Openly participating in a wedding also signalled the achievement of trust between the two parties, monarch and noble. As a result, the following case studies confirm Farrell's work, revealing that trust and loyalty were possible despite the power differential which existed between the monarchy and the nobility. ${ }^{12}$

Elizabeth understood "right well" the power of the royal person. Contemporary John Hayward described her movement through London on the day before her coronation in January 1559. The queen "most royally furnished... knowing right well that in pompous ceremonies a secret of government doth much consist, for that the people are naturally both taken and held with exterior shows." The royal person had the ability to dazzle the people, to provoke "solemnity" as well as "contentment and admiration."13 A formidable entity, the royal person transcended the natural in favour of the divine, awe-inspiring nature of kingship-

\footnotetext{
10 Hayward, 15

11 Barrow, 69.

12 Farrell, 86

${ }^{13}$ Hayward, 15; Louis Montrose, "Elizabeth through the Looking Glass: Picturing the Queen's Two Bodies," in The Body of the Queen: Gender and Rule in the Courtly World, 1500-2000, ed. Regina Schulte (New York and Oxford: Berghahn Books, 2006), 75.
} 
it was the King's Two Bodies theory on display. Even by the end of her reign, Elizabeth still knew and used the power of the royal person. Her supportive participation in the 1600 Herbert-Russell wedding serves as a quintessential example. ${ }^{14}$ The queen organised a very public procession to the marriage ceremony, travelling first by barge along the River Thames. ${ }^{15}$ She was met by the bride at Blackfriars and, alighting there, was "carried from the water side" in a chair held aloft, in full view of spectators. ${ }^{16}$ The queen was then slowly transported through the streets to the church for the ceremony so that passers-by might behold her magnificent presence. ${ }^{17}$ The royal person had multiple meanings, a power all its own, and Elizabeth exploited it fully in her sponsorship of marriages, indicating that she appreciated the many aspects of monarchy that it encompassed.

James was frequently involved in noble marriages as king of Scotland prior to 1603 . In the 1590 s he attended numerous wedding banquets. He celebrated the Lyon-Murray, Fraser-Stuart, and Orkney-Livingstone marriages, for example, which demonstrated his endorsement of the unions and the institution of important monarch-noble connections. ${ }^{18}$ Generally speaking, monetary offerings at the event of noble weddings occurred infrequently prior to 1603 , the 1588 Huntly-Stewart marriage being a notable exception. Once king of England, James's supportive involvement looked very much like the previously described HerbertVere and Somerset-Howard weddings. He aided in the arrangement of marriages, attended ceremonies and festivities, and offered financial gifts. This last element was contrary to his predecessor Elizabeth who rarely provided monetary backing along with her royal presence at a noble wedding. ${ }^{19}$ But both monarchs traded in the currency they possessed in abundance-exclusive monarchical privilegesand they granted these to the nobility, strengthening their monarch-noble patronage networks, as this chapter will show.

\footnotetext{
14 Nichols, Elizabeth, vol. 1, xii. Henry Somerset, styled lord Herbert, later became the fifth earl and first marquess of Worcester.

15 Sidney Papers, vol. 2, 195; Tarnya Cooper and Jane Eade, eds., Elizabeth I and Her People (London: National Gallery Publications, 2013), 46-48.

16 CP, Vol. 186/134; TNA, SP 12/275/6, 20; Sidney Papers, vol. 2, 203.

17 Sidney Papers, vol. 2, 203; Cokayne, ed., vol. 12/2, 858.

18 TNA, SP 52/55/104, 110; ibid, SP 52/59/29; James Balfour Paul, ed., The Scots Peerage, vol. 5 (Edinburgh: David Douglas, 1908), 530 .

${ }^{19}$ In 1560, Elizabeth provided a wedding gift to her maid of honour Douglas Howard for her marriage to John Sheffield, second baron Sheffield. See ODNB, s.v. "Sheffield [née Howard], Douglas, Lady Sheffield." She may also have assisted with Lady Anne Russell's jointure in 1600. See CP, Vol. 186/134.
} 
Besides material support, James contributed to noble weddings in another way that Elizabeth did not: he gave away the bride. This was an important symbolic gesture, particularly within the Church of England. As David Cressy has explained, giving away the bride symbolised not only the father or guardian's permission and approval of the marriage but also the woman's transfer, not to her husband, but to God, "through his minister, the priest."20 When James became part of the marriage ceremony he effectively commandeered parental consent. His central placement in the ritual of giving away the bride underlined his paternal, royal, and divine authorities. His triad of blessings upon the union reaffirmed the hierarchy and signalled endorsement and trust while it also implied the couple's required obedience and loyalty.

\section{Database}

The database provides a starting point to a greater understanding of how and why Elizabeth and James lent their approbation and support. Already shown in Table 2.2, two-thirds of Elizabeth's and nearly $90 \%$ of James's imputed involvement was in encouragement of matches. Table 3.1 delineates their sponsorship efforts further, examining it by decade. It reveals that apart from the 1560s, Elizabeth supported the majority of marriages in which she became involved. This revises Stone's belief that "Elizabeth interfered frequently, but hardly ever positively." 21 Moreover, James exhibited very high levels of sponsorship throughout his reign. These elevated percentages are perhaps unsurprising when much of their marriage participation was in encouragement of those serving in the royal household whom Elizabeth or James would have known well. Indeed, Elizabeth and James had an in loco parentis right to organise and approve royal household marriages and they frequently played matchmaker. Supportive involvement was regular, too, spanning the decades of their reigns. The Lindsay-Lyon, Herbert-Vere, and Somerset-Howard weddings, for example, attest to James's engagement in the marriages of his gentlemen of the bedchamber. Similarly, the Cobham-Newton, ${ }^{22}$ Northampton-Snakenborg, ${ }^{23}$ Pembroke-

\footnotetext{
20 Cressy, Birth, 339.

21 Stone, Crisis, 605.

22 Frances Newton was a gentlewoman of the queen's privy chamber. In 1560 she married William Brooke, tenth baron Cobham. See Merton, 264-265; Kinney, ed., 28, 100; Rimbault, ed., 173.
} 
Table 3.1: Supportive monarchical involvement in noble marriages $(n=129)$

\begin{tabular}{ll|l} 
& $\begin{array}{l}\text { Elizabeth I } \\
\text { Support/ } \\
\text { Total Involvement (\%) }\end{array}$ & $\begin{array}{l}\text { James VI/I } \\
\text { Support/ } \\
\text { Total Involvement (\%) }\end{array}$ \\
\hline $1558-1569$ & $9 / 19(47 \%)$ & - \\
$1570-1579$ & $14 / 19(74 \%)$ & - \\
$1580-1589$ & $6 / 9(67 \%)$ & $7 / 7(100 \%)$ \\
$1590-1599$ & $6 / 7(86 \%)$ & $10 / 14(71 \%)$ \\
$1600-1609$ & $3 / 4(75 \%)$ & $23 / 25(92 \%)$ \\
$1610-1619$ & - & $12 / 13(92 \%)$ \\
$1620-1625$ & - & $11 / 13(92 \%)$ \\
Totals & $\mathbf{3 8 / 5 8 ( 6 6 \% )}$ & $\mathbf{6 3 / 7 1 ( 8 9 \% )}$
\end{tabular}

Sidney, ${ }^{24}$ and Derby-Vere alliances demonstrate Elizabeth's backing of the women in her household. ${ }^{25}$

In addition, both monarchs invited their heirs presumptive to court to serve in the royal household. This enabled them to keep close possible successors like the Grey, Hastings, or Carey sisters or Lady Arbella Stuart. ${ }^{26}$ Despite their blood ties, claimants posed the greatest danger to the reigning monarch. This is why it was important for Elizabeth or James to enact a patron-client relationship at the marriage of any potential successor. Patronage bonds which recognised the couple and their respective families' amalgamation also required loyalty and obedience and re-directed joining kin groups' attention to the crown. Acting in loco parentis allowed Elizabeth or James to manage carefully heirs' marriages as in the case of the 1560 planned Arran-Grey union as mentioned in chapter two. Elizabeth attended the 1563 marriage of her cousin Lady Katherine Carey to

${ }^{23}$ Helena Snakenborg was a gentlewoman of the privy chamber. In 1571 she married William Parr, marquess of Northampton. See Merton, 45-46; Kinney, ed., 29, 117; Rimbault, ed., 160; Salignac, vol. 4, 94; HMC, Rutland, vol. 1, 92; William Camden, Annales (London: Printed for Benjamin Fisher, 1625), 283; Charles Angell Bradford, Helena, Marchioness of Northampton (London: s.n., 1936), 59; ODNB, s.v. "Parr, William, marquess of Northampton."

24 Mary Sidney was a gentlewoman of the privy chamber. She wed Henry Herbert, second earl of Pembroke, in 1577. See Rimbault, ed., 160; Merton, 232; Kinney, ed., 30, 120.

25 Lady Elizabeth de Vere was a maid of honour. In 1595 she married William Stanley, sixth earl of Derby. See Wright, ed., 440; Kinney, ed., 31, 34, 104.

26 Ladies Katherine and Mary Grey were Henry VIII's great-nieces while Lady Arbella Stuart was his great-great niece. See Merton, 261; Kinney, ed., 27, 32. Ladies Frances, Katherine, Elizabeth, Mary, and Anne Hastings were the greatgreat-granddaughters of George, duke of Clarence, younger brother of King Edward IV. Ladies Frances and Katherine definitely served in Elizabeth's household. See Merton, 126, 258-259; Kinney, ed., 33. Lady Mary Hastings may also have been a maid of honour, the queen having discouraged an offer of marriage for her from Russia's Ivan the Terrible. See Edward A. Bond, Russia at the Close of the Sixteenth Century (London: T. Richards, 1856), xlviii-lii, 187, 195-196. Ladies Margaret, Philadelphia, and Katherine Carey were the daughters of Henry, first baron Hunsdon, the queen's first cousin, who was "widely believed to be an illegitimate son of Henry VIII." See Merton, 37. 
Charles Howard, second baron Howard of Effingham. ${ }^{27}$ It is highly possible that she was present at the 1584 wedding of Lady Katherine's sister, Lady Philadelphia Carey, and her marriage to Thomas Scrope, later tenth baron Scrope. Both women served in Elizabeth's household and would continue to do so until $1603 .^{28}$ Moreover, the queen was present at the 1571 below-mentioned marriage of her kinswoman and maid of honour Elizabeth Hastings to Edward Somerset, lord Herbert, later fourth earl of Worcester. ${ }^{29}$ Conversely, James, apart from his cousin Lady Arbella, did not have other significant threats to his position on the throne of England since his line of succession was confirmed through his own children. That said he was unsuccessful in advantageously managing Lady Arbella's marriage just as Elizabeth had failed to match strategically the Grey sisters as chapter five will illustrate.

As Table 3.1 shows, Elizabeth's utilisation of a supportive approach to marriages rose and fell through her reign though the number of peers was stable. ${ }^{30}$ Still, her favourable, encouraging involvement in marriages remained high from 1570 s, peaking in the 1590 s percentage-wise. These elevated percentages may have been connected to parliamentary debates on monarchical privileges as well as what Heal has described as "the crisis of the patronage system" which arose from "the difficult war [with Spain] years of the 1590s."31 Advocacy for marriage served as an important means of fostering stronger bonds with the nobility. The growing supportive participation in the latter stage of her reign suggests that Elizabeth needed to form stronger connections with members of the aristocracy to gain their backing for her monarchy. James's use of a supportive approach to noble marriage varied only marginally, remaining high especially after his ascension to the English throne. This suggests that he also regularly pursued connections with his nobility. It also implies that he wished to exert firmly crown authority over that of the nobility; to bind that group to him through the obedience and

${ }^{27}$ Robert W. Kenny, Elizabeth's Admiral: The Political Career of Charles Howard, Earl of Nottingham, 1536-1624 (Baltimore and London: The Johns Hopkins Press, 1970), 16; TNA, SP 70/60/100.

${ }^{28}$ Lady Margaret Carey, the sister of Ladies Philadelphia and Katherine Carey, may have served in Elizabeth's household as well. It is possible that Elizabeth attended Lady Margaret's marriage to Edward Hoby on 21 May 1582, as she herself knighted Hoby at Somerset House the day after the wedding. See Merton, 259; Kinney, ed., 25, 30, 31; ODNB, s.v. "Hoby, Sir Edward."

${ }^{29}$ Salignac, vol. 4, 319.

${ }^{30}$ Stone, Crisis, 99. In 1558 when Elizabeth ascended the throne there were 57 peers. When she died in 1603 there were 55 .

${ }^{31}$ Heal, 21. 
reciprocation required by royal patronage. Indeed, from 1585 to 1599 he supported the majority of marriages in which he was involved. A number of these were peace-making matches which the king hoped would bring greater stability to his Scottish court and kingdom. ${ }^{32}$

Between 1603 and 1609 James focussed his noble marriage sponsorship on Anglo-Scottish intermarriages. With the failure of an administrative union and regular financial support, from 1614 James entered a phase of personal rule dependent on his favourite courtier, the royal prerogative, and crown privileges since Parliament did not meet again until 1621.33 James's "excessive largesse" in the early years of his English reign together with the later "monopolistic control" of his favourites once again caused a patronage crisis. $^{34}$ Lacking parliamentary supply, the king relied upon the sale of titles and, consequently, the number of peerages grew. ${ }^{35}$ From 1615 to 1625 titular peers in England increased from about 80 to around 120 due to sales largely overseen by the king's favourite, Buckingham. ${ }^{36}$ As Brown has observed, the selling of honours "had the dual effect of strengthening the nobility by widening its base, and of reinforcing allegiance to the king, the source of their status." 37 Around fourteen titles were created in the Scottish peerage in this same period. All of the marriages James advocated in the final decade were of those peers who had been elevated during his reigns. Through these endorsements he not only bolstered those peers elevated between 1603 and 1615 but also legitimised Buckingham's post-1615 sales.

As mentioned in the introduction, the linking of patronage to policy was the basis of effective monarchical rule and a contributing factor to kingdom stability. Table 2.3 revealed that 40\% of Elizabeth's and one-third of James's noble-marriage participation linked to policies. And, Table 2.4 showed that of all the policies, Elizabeth most often advocated for marriages that would bolster Protestantism in her kingdom. ${ }^{38}$ Her infrequent support for Catholic intra-denominational

\footnotetext{
32 Prior to 1603, at least four noble marriages which had James's imputed support were also peace-making gestures: 1585 Caithness-Gordon, 1590 Lindsay-Lyon, 1592 Mar-Stewart, and 1596 Orkney-Livingstone.

33 Croft, King James, 73, 87, 94, 97.

34 Heal, 21.

35 Stone, Crisis, 103-104.

${ }^{36}$ LJ, vol. 2, 688-689; ibid, vol. 3, 208-209; Russell, James, 179; Kenyon, ed. 22.

37 Brown, "Scottish Aristocracy;" 565.

38 Three Protestant intra-denominational marriages had Elizabeth's imputed support: 1565 Warwick-Russell, 1581 Rich-Devereux, and 1594 Northumberland-Devereux.
} 
weddings may have stemmed, in part, from her relationship with her half-sister, the staunchly Catholic Mary I. ${ }^{39}$ Mary imprisoned Elizabeth and sought her execution for her alleged involvement in the 1554 Wyatt Rebellion.40 It is possible that this potentially life-threatening event, along with regular Catholic plotting during her own reign, would have motivated Elizabeth's desire to weaken Catholicism in her kingdom. In addition, the events which took place from 1568 to 1571-Mary, queen of Scots's 1568 flight into England, the 1569 Northern Rebellion, the 1570 papal bull which excommunicated Elizabeth, and the 1571 Ridolfi plot-affected her management of marriages involving Catholics. Significantly, after 1571 the queen no longer offered public support to Catholic intra-denominational marriages of the upper-level nobility. Indeed, only one such marriage received the queen's approval after 1571 and it was for a lower-level aristocratic wedding which she personally attended. ${ }^{41}$ Moreover, where Elizabeth had ignored interdenominational marriages prior to 1571, afterwards she became visibly involved.

By shifting from non-recognition to backing of interdenominational marriages, Elizabeth demonstrated a new tactic for managing upper-level noble marriages involving Catholics. Her fresh attitude reflected an unofficial but deliberate policy of matching Catholic with Protestant aristocracy to weaken Rome's influence and safeguard Protestantism in England. ${ }^{42}$ Notably, all but one of the post-1571 interdenominational weddings matched a Catholic groom with a Protestant bride, thus, bringing Catholic noblemen to the reformed religion. ${ }^{43}$ Relative to this fact was that fathers as heads of household were responsible, in theory, for the education of children. But the reality was that mothers assumed this task. ${ }^{44}$ Consequently, promotion of interdenominational marriages boosted the proliferation of the reformed religion as Protestant mothers led spiritual education and offspring assumed their religion. Overall, the majority (87\%) of patron-client relationships Elizabeth fashioned through supportive involvement in

39 Three Catholic intra-denominational marriages had Elizabeth's imputed support: 1566 Southampton-Browne, 1571 Paget-Newton, and 1577 Wharton-Clifford.

40 David Starkey, Elizabeth: The Struggle for the Throne (New York: Harper Collins Publishers, 2001), 134.

41 This was the 1577 Wharton-Clifford marriage described below.

42 Six interdenominational marriages had Elizabeth's imputed support: 1571 Oxford-Cecil, 1571 Herbert-Hastings, 1577 Cumberland-Russell, 1580 Sackville-Howard, 1584 Scrope-Carey, and 1591 Browne-Sackville.

43 The exception is the 1580 Sackville-Howard marriage which has been ascribed as joining a Protestant groom with a Catholic bride.

${ }^{44}$ Rosemary O’Day, The Family and Family Relationships, 1500-1900 (New York: St. Martin's Press, 1994), 168. 
weddings was longstanding. ${ }^{45}$ And, her encouragement of interdenominational marriages, in particular, was largely successful, revealing the fundamental efficacy of the approach.

James also participated in marriages linked to his religious policy. He promoted Protestant intra-denominational and interdenominational marriages more than Catholic intra-denominational ones, although the interdenominational matches he supported allied Protestant noblemen with Catholic wives-the opposite of what typically occurred in Elizabeth's reign. ${ }^{46}$ In three instances the king required conversion to Protestantism before the wedding could take place. ${ }^{47}$ Only once did James's endorsement relative to religion result in a foundering of the patron-client relationship: the Huntly-Stewart marriage described below. The majority of James's policy-based involvement concerned his promotion of AngloScottish noble marriages. The formation of Britain was the key initiative during his early reign of England and he advanced this policy by backing English and Scottish intermarriages. After 1603, the king advocated for numerous Anglo-Scottish alliances. The bulk of Anglo-Scottish noble weddings took place between 1604 and 1614. Every union-related marriage that the king supported resulted in a successful and long-term patron-client relationship. And, most of James's sponsorship of marriages in general produced enduring patron-client ties (85\%). ${ }^{48}$ His methodical encouragement was effective for connecting with the nobility, upholding crown authority, and communicating his policy for unified kingdoms.

Interestingly, in only one case did supportive engagement in noble marriages relate to the succession: the 1581 Beauchamp-Rogers wedding as mentioned in chapter five. This is because neither Elizabeth nor James probably desired any of their potential heirs to marry, e.g., Ladies Katherine and Mary Grey or Lady Arbella Stuart (not James's own children). Perhaps as a result, the case studies below have connected more to Elizabeth's or James's personal legacy

45 Five of thirty-eight instances of supportive involvement $(13 \%)$ did not produce a long-term patron-client relationship.

46 Four Protestant intra-denominational marriages had James's imputed support: 1588 Huntly-Stewart, 1592 MarStewart, 1620 Buckingham-Manners, and 1621 Mordaunt-Howard. Three interdenominational noble marriages had James's imputed support: 1605 Knollys-Howard, 1610 Erskine-Hay, and 1614 Roxburghe-Drummond. One Catholic intra-denominational noble marriage had James's imputed support: 1606 Arundel-Talbot.

${ }^{47}$ These marriages included the 1588 Huntly-Stewart, 1592 Mar-Stewart, and 1620 Buckingham-Manners. See BL, Cotton MSS, Caligula D/I fol. 317; HMC, Mar and Kellie, vol. 1, 65; Brown, Noble Society, 129; John Hacket, Bishop Hacket's Memoirs of the Life of Archbishop Williams (London: Sam Briscoe, 1715), 10.

48 Ten of sixty-three instances of supportive involvement (15\%) did not produce a long-term patron-client relationship. 
rather than succession. The examples that follow reveal, in part, these legacies: the conversion of Catholic nobility to Protestantism through marriage in Elizabeth's reign and Briticisation in James's. ${ }^{49}$ Like biological parents Elizabeth and James were interested in the lives and futures of their favoured noble couples. Encouragement of these couples often extended to their offspring, allowing the monarchs to future-proof their respective long-term strategies. ${ }^{50}$ In this way, a supportive approach to marriages advanced monarchical authority through the instigation of monarch-noble connections and helped realise Elizabeth's and James's legacies.

\section{Elizabethan case studies}

The 1560 Arran-Grey match described in chapter two was the only noble marital alliance in the Elizabethan period which was associated with AngloScottish union. And, as stated above, only once did she show support for a succession-related wedding. Instead, much of her advocacy linked to her religious policy. From the very beginning of her reign Elizabeth backed numerous intra- and interdenominational marriages that connected to the re-establishment of Protestantism in England and her religious settlement. The religious policy that Elizabeth maintained and upheld throughout her reign included a Protestant national church with the monarch as the supreme head or governor; a moderate approach to Protestantism which would appeal to the majority of her subjects; an emphasis on allegiance and conformity to the national church, and uniformity of worship throughout the kingdom. This policy, aided by numerous statutes, might be termed Elizabeth's legacy, the purpose of which was to safeguard the continuation of Protestantism. Several of the case studies below also illustrate the queen's process of establishing her legacy of converting England's Catholic aristocracy to Protestantism through marriage.

\footnotetext{
49 Pearson, 29.

${ }^{50}$ For example, Elizabeth patronised noble fathers and sons like the first and second barons Hunsdon, tenth and eleventh barons Cobham, first and second earls of Essex, first and second earls of Pembroke, and fourth and fifth earls of Worcester. Likewise, James patronised the second/eighteenth and third/nineteenth earls of Mar, first and second marquesses of Hamilton, first and second marquesses of Huntly, and first, second, and third dukes of Lennox.
} 
Elizabeth took the opportunity to champion her religious policy through her involvement in the 1565 Warwick-Russell marriage; a match arranged by her favourite courtier, Leicester. She was aware in advance of the planned marital alliance between Ambrose Dudley, earl of Warwick, and Lady Anne Russell, daughter of the second earl of Bedford, and enthusiastically approved of it. ${ }^{51}$ The queen already enjoyed individual patron-client relationships with both Warwick and Bedford, but purposefully acknowledged and patronised the union of their families. ${ }^{52}$ The couple and their kin, all staunch Protestants and supporters of the Church of England, received the honour of having the ceremony solemnised in either the queen's closet or chapel at Westminster on 11 November 1565.53 Elizabeth personally attended the sumptuous banquet and tilting and jousting entertainments which followed. 54 This publicly-bestowed gift of the royal presence at the marriage and its celebrations signalled the queen's recognition of the powerful and influential Dudley and Russell families' alliance which the couple represented. The bestowal of personal attendance served to transfer the families' new ties and allegiances from each other to the crown. At the same time, Elizabeth's overt patronage connected with the crown's Protestant-centred religious agenda.

The significance of the Warwick-Russell marriage lay in its timing. In 1565 the queen's religious settlement and the thirty-nine articles, which defined the position of the Church of England, were still relatively new. Elizabeth's position as supreme governor of the church, while confirmed by Parliament, was unsteady especially as many among the government continued the call for greater reform to the national church. ${ }^{55}$ The Dudleys and Russells were among those noble families

51 Raphael Holinshed, Chronicles of England, Scotland and Ireland, ed. Henry Ellis, vol. 4 (London: J. Johnson, 1808), 229; E. S., "An Unpublished Letter of Robert Dudley, Earl of Leicester, 1564," Notes and Queries 6 (1881): 283-284.

52 Prior to the marriage, Warwick served as master of the ordnance and in the queen's army at Le Havre and he was elected as a knight of the Order of the Garter. Bedford served as Custos Rotulorum of Buckinghamshire, lord-lieutenant of Devon and Cornwall, a privy councillor, and a knight of the Order of the Garter. See Kinney, ed., 3, 8, 49, 57, 58, 184, 249; ODNB, s.v. "Dudley, Ambrose, earl of Warwick; ibid, s.v. "Russell, Francis, second earl of Bedford."

53 Rimbault, ed., 160; Elizabeth Goldring, Faith Eales, Elizabeth Clarke, and Jayne Elisabeth Archer, eds., John Nichols's The Progresses and Public Processions of Queen Elizabeth I, new ed., vol. 1 (Oxford: Oxford University Press, 2014), 441.

54 J. H. Wiffen, Historical Memoirs of the House of Russell, vol. 1 (London: Longman, et al., 1833), 425-431; Holinshed, vol. $4,229$.

55 Elton, England, 289. 
who favoured more change. ${ }^{56}$ The queen, however, did not desire further adjustment which would shift the church from her preferred moderate stance. Moreover, she believed that the royal prerogative encompassed church matters and, thus, any alterations to the church or religious policies were hers alone to consider. ${ }^{57}$ So, while Elizabeth's enthusiasm and open display of support for the Dudleys and Russells were genuine, it is also possible that the Warwick-Russell wedding provided an excellent opportunity for the queen to pacify, temporarily at least, those persistent voices which clamoured for more parliamentary discussion on religion and more modifications to the church. Furthermore, by outwardly embracing the Dudleys and the Russells who wished for additional church reform, the queen inferred that she might consider amendments in the future, especially when Bedford and Leicester were already privy councillors and Warwick became one in 1573. Based on this assumption, Elizabeth's open celebration of the Warwick-Russell marriage was, tactically-speaking, astute: the 1566 parliamentary sessions did not focus on religious reform but rather concentrated on the queen's marriage and succession. ${ }^{58}$

The Elizabeth-Warwick-Russell patron-client relationship instituted at the time of the marriage endured, making the queen's involvement successful. Following the wedding, Elizabeth invited Lady Anne, the new countess of Warwick, to join her household as a gentlewoman of the privy chamber. Anne of Warwick became the queen's "most faithful and devoted servant" and remained in royal service until Elizabeth's death in $1603 .{ }^{59}$ Warwick held multiple military and government offices, effectively becoming a defender of the kingdom as well as the Elizabethan religious policy to safeguard Protestantism. ${ }^{60} \mathrm{He}$ served as joint commissioner of the Elizabeth's army raised against the 1569 Catholic-inspired Northern Rebellion. ${ }^{61}$ Further solidifying their patron-client bond, the queen granted him property and land previously owned by those attainted for treason for their part in the rebellion. ${ }^{62}$ Later, in the office of lord-lieutenant of Warwickshire,

\footnotetext{
56 Enis,16.

57 Hartley, ed., vol. 1, 199; ibid, vol. 2, 55, 191, 419-420; Doran, Circle, 222.

58 Lockyer, Britain, 194.

59 Sidney Papers, vol. 1, 42; Merton, 43; Kinney, ed., 29, 129-130.

60 TNA, SP 12/44/148; ibid, SP 12/59/180; Adams, “'Because I am of that Countrye,"' 46; Kinney, ed., 3, 8, 62, 129-130,

179. See also CPR, 1563-1566, 388; ibid, 1566-1569, 175.

61 TNA, SP 12/59/180.

${ }^{62}$ CPR, 1569-1572, 203, 407-408.
} 
Warwick enacted measures to embed Protestantism in what was a known Catholic stronghold."63 He supported the appointment of Protestant candidates to the commission of the peace, replacing long-serving Catholic ones; the new members having dutifully subscribed to the act of uniformity as requested by the Privy Council.64 Evidence indicates that Lady Anne also used her influence as a member of the royal household to suggest an appointee to a commission of the peace. ${ }^{65}$ The earl's efforts altered the previously Catholic Warwickshire into a Protestantleaning county. His actions revealed the Elizabethan government's tacit approval of the political isolation of Catholic subjects and transformation of their strongholds for the entrenchment and preservation of the reformed religion. ${ }^{66}$ And, because the movement to marginalise Catholics and remove them from decision-making positions was unofficial, indeed "silent," it demonstrated Elizabeth's use of the royal prerogative.

It was vital that Elizabeth acknowledge and participate in the WarwickRussell marriage which united two wealthy, prominent families, creating a strong and significant lateral bond in a vertically-aligned hierarchy. Through her initial and continuing patronage of the Warwicks the queen recurrently directed the Dudley and Russell kinship ties and allegiances to the crown rather than to each other. Elizabeth also used marriage sponsorship to lend obvious support to families who supported the Church of England and helped to entrench Protestantism in the kingdom-her religious policy. Her oversight and patronage show the importance of acknowledging the bonds of marriage that brought powerful families together to ensure loyalties remained with the crown.

\section{Oxford-Cecil and Herbert-Hastings, 1571}

The Northern Rebellion and Ridolfi plot likely served as an impetus to the earl of Warwick's political manoeuvrings in Warwickshire. But these events unquestionably altered Elizabeth's response to her Catholic and Catholicsympathising noble subjects and their marriages. In December 1571, against the

\footnotetext{
63 TNA, SP 12/44/148; Adams, “'Because I am of that Countrye,"” 44, 46, 47; Enis, 1-2.

${ }^{64}$ Enis, 2, 11-12; Alison Wall, "'The Greatest Disgrace': The Making and Unmaking of JPs in Elizabethan and Jacobean England," EHR 119 (2004): 313, 319-320. Warwickshire justices had been slow to subscribe to the act of uniformity. See TNA, SP 12/66/88; ibid, SP 12/67/47.

65 Wall, “'The Greatest Disgrace,"' 315.

66 Adams, “'Because I am of that Countrye,"” 47; Pearson, 29.
} 
backdrop of Catholic plotting and revolt, four marriages took place in a single week in London. All of them were "celebrated with pleasure and contentment, and with the approval of the court."67 Two of these were lower-level noble marriages of Elizabeth's female household servants for whom the queen acted in loco parentis: maid of honour and kinswoman Lady Mary Howard, daughter of William, first baron Howard of Effingham; and gentlewoman of the bedchamber Nazareth Newton, daughter of Sir John Newton. ${ }^{68}$ Lady Mary married Edward Sutton, fourth baron Dudley, in what was a Protestant intra-denominational union. Newton was joined in matrimony to Thomas Paget, fourth baron Paget; both were Catholics. ${ }^{69}$ That the Paget-Newton wedding was celebrated with Elizabeth's approval despite both the bride and groom's Catholicism highlighted the loyalty and trust between Newton, Paget, and the queen at the time though it would be temporary.

The two other marriages taking place that week were of greater significance since they involved young, upper-level noblemen. A joint ceremony solemnised at Westminster united royal ward Edward de Vere, ${ }^{70}$ seventeenth earl of Oxford, to Lady Anne Cecil, daughter of William, first baron Burghley, Elizabeth's secretary of state, master of the court of wards, and trusted servant; and Edward Somerset, styled lord Herbert, later fourth earl of Worcester, to Lady Elizabeth Hastings, daughter of Francis, second earl of Huntingdon. ${ }^{71}$ Lady Elizabeth was serving in the royal household as a maid of honour in 1571 so it is likely that the queen granted in loco parentis approval for her marriage to Herbert-an alliance probably arranged by the couple's parents. ${ }^{72}$ Although Burghley organised his daughter's match, the queen also gave "her consent" to the Oxford-Cecil marriage as was her right, due to the earl's position as a royal ward under Burghley's

\footnotetext{
67 Salignac, vol. $4,319$.

68 Kinney, ed., 28, 33. Lady Mary Howard was Elizabeth's first cousin once removed.

${ }^{69}$ Although she was loyal to the queen, it is highly likely that Newton was Catholic. Her first marriage had been to Sir Thomas Southwell of Wood Rising, Norfolk, whose family were known Catholics. Newton's marriage to Paget ended in 1582 when they separated. Paget was later convicted of treason and attainted in 1587 for Catholic plotting. See ODNB, s.v. "Paget, Thomas, fourth Baron Paget."

70 CSPD, 1547-1580, 225.

${ }_{11}$ Salignac, vol. 4, 315, 319; CSPSp, 1568-1579, 358; John Strype, Annals of the Reformation, new ed., vol. 2/1 (Oxford: Clarendon Press, 1824), 178; Pearson, 20, 28-29; Mark Anderson, "Shakespeare" by Another Name: The Life of Edward de Vere, Earl of Oxford, the Man who was Shakespeare (New York: Gotham Books, 2005), 50. Ironically, in 1562 a marriage between Oxford and Lady Elizabeth Hastings had been arranged. This agreement ended with the sixteenth earl's death and Oxford's subsequent wardship. See HMC, Report on the Manuscripts of the Late Reginald Rawdon Hastings, ed. Francis Bickley, vol. 1 (London: H. M. Stationery Office, 1928), 319 [hereafter HMC, Hastings]. Furthermore, Anne Cecil had been intended for Sir Philip Sidney, a match which fell through. See CP, Vol. 156/14; ibid, Vol. 156/19.

72 Kinney, ed., 33.
} 
guardianship. ${ }^{73}$ She personally attended the double wedding. ${ }^{74}$ Her appearance publicised her acknowledgement of the bonds being established between the families-the Veres and Cecils and the Somersets and Hastings-as well as the institution of patron-client relationships with the couples who represented their families' new ties. The queen's participation highlighted the prevailing social hierarchy and the families' required loyalty and reciprocation to the crown. The queen's backing of the Oxford-Cecil match also showed her support of Burghley whom she had recently ennobled in February 1571. The marriage of Burghley's daughter to an upper-level peer was an achievement which signified the secretary's prominent social status. ${ }^{75}$

The Oxford-Cecil and Herbert-Hastings marital alliances were interdenominational which made them weighty events. The Cecils and Hastings were Protestant while the grooms were from Catholic-leaning families. ${ }^{76}$ From 1567 both Oxford and Herbert appeared on Spanish lists of supporters of Catholicism in England: "Lord Harbarde [Herbert]" was deemed a Catholic while Oxford was recorded as "Well affected towards Catholics."77 This assessment was alarming when Oxford and Herbert, as upper-level noblemen, though still young, would presumably one day possess immense political influence and wealth in Protestant England.78 As a result, Oxford's and Herbert's marriages were of consequence to the kingdom as they might help to tip the scales either for or against Protestantism. Aware of their Catholic connections, Elizabeth seized the opportunity to display publicly the royal person and demonstrate open crown approval of their pointedly interdenominational marriages which linked them to staunch Protestants. The queen's presence delivered an unmistakeable message at home and abroad that even the highest-level Catholic or Catholic-sympathising subjects would be brought into the Protestant fold. ${ }^{79}$

\footnotetext{
73 TNA, SP 12/26/113.

74 HMC, Rutland, vol. 1, 94.

75 See Cokayne, ed., vol. 2, 429.

76 Salignac, vol. 4, 319; CSPR, 1558-1571, 266, 398.

77 CSPR, 1558-1571, 266. Similar lists over the next thirty years would routinely list Oxford as sympathetic to the Catholic cause. See Alan H. Nelson, Monstrous Adversary, The Life of Edward de Vere, 17th Earl of Oxford (Liverpool: Liverpool University Press, 2003), 49.

78 Hurstfield, Queen's Wards, 254.

79 Pearson, 29; ODNB, s.v. "Vere, Edward de, seventeenth earl of Oxford."
} 
Elizabeth's patronage of Oxford and Lady Anne continued post-wedding. In 1578 and 1579 Oxford received large grants of land and property formerly owned by the attainted and executed Thomas Howard, fourth duke of Norfolk. ${ }^{80}$ But, ultimately, the queen's supportive involvement in the Oxford-Cecil marriage proved unsuccessful, lasting less than ten years. The collapse of the ElizabethOxford-Cecil patron-client bond was likely due to the earl's own tempestuous nature and his ill-treatment of Lady Anne and, by extension, Burghley. ${ }^{81}$ Furthermore, despite his instruction in Protestantism in Burghley's household, sometime in the late 1570 s Oxford turned to Catholicism. ${ }^{82}$ Based on later conformity it proved neither a deep or serious conversion. Nonetheless, it was a dangerous step to take, especially as it became treason to "withdraw to the Romish religion" in 1581.83 In addition, Oxford's dalliance with one of the queen's chamberers resulted in the birth of a child, drawing Elizabeth's ire. ${ }^{84}$ The earl's eventual confession of his conversion to Catholicism caused equal royal displeasure. ${ }^{85}$ In the end, the queen was aware that Oxford held little wealth and no political power. His only advantage was his position as Burghley's son-in-law. Because of that, his relationship with the queen could be repaired to an extent but not before he spent time in the Tower. ${ }^{86}$ Incarceration was Elizabeth's response to "light-weight" noblemen "with little following" who turned to Catholicism. ${ }^{87}$

After achieving freedom in 1581, Oxford showed support for the queen's religion by joining a group, including leading Protestant courtiers Bedford, Leicester, and Sir Francis Walsingham, that financed the purchase of church livings to be filled by Protestant ministers. ${ }^{88}$ He also served on several high-profile trials in service to the crown, but he held no administrative positions. He did, however,

\footnotetext{
80 CPR, 1575-1578, 408-409.

81 CP, Vol. 160/115; Hurstfield, Queen's Wards, 253; Pearson, 161, 163. See also TNA, SP 12/201/4. Burghley wrote, "no enemy I have can envy this match [between Oxford and Lady Anne]."

82 ODNB, s.v. "Vere, Edward de, seventeenth earl of Oxford."

83 SR, vol. 4, 657-658: 23 Eliz. I, 1581, c. 1; CSPD, 1581-1590, 3.

84 Oxford had an affair with Anne Vavasour who is variously described as a maid of honour and gentlewoman of the bedchamber. See HMC, Hastings, vol. 2, 29-30; CSPD, 1547-1580, 703; Kinney, ed., 34. After Oxford and Vavasour's child was born, the earl was kept in the Tower from March to July 1581 and barred from attending court for a further two years. See TNA, SP 12/149/156; Cokayne, ed., vol. 10, 251; Rickman, 29-32.

85 CSPD, 1581-1590, 1, 22-23, 38-40; ibid, Addenda, 1580-1625, 48-49; CSPSp, 1580-1586, 78, 246.

86 TNA, SP 12/149/156; Cokayne, ed., vol. 10, 251; Pearson, 177; Rickman, 29-32.

87 Pearson, 110.

${ }^{88}$ HMC, Tenth Report, Appendix, Part IV. The Manuscripts of the Earl of Westmorland (London: Eyre and Spottiswoode, 1885), 499; Pearson, 110; Richard T. Spence, The Privateering Earl: George Clifford, Third Earl of Cumberland (London: Stroud, 1995), 34-35; Claire Cross, The Puritan Earl: The Life of Henry Hastings, Third Earl of Huntingdon, 1536-1595 (London: Macmillan, 1966), 264.
} 
retain the hereditary office of lord great chamberlain, a ceremonial role. ${ }^{89}$ Deeply in debt, Oxford petitioned Elizabeth for a $£ 1,000$ annuity which was granted in 1586, proving either that he still had her good will or that Burghley had her pity. ${ }^{90}$ When Anne of Oxford died in 1588, Oxford remarried in 1592, this time to Elizabeth Trentham, one of the queen's maids of honour. ${ }^{91}$ Acting in loco parentis, the queen probably also approved of this match, especially as Trentham was "on friendly terms with the queen" and her father was a loyal servant to the crown and committed Protestant. ${ }^{92}$

The Elizabeth-Herbert-Hastings patron-client relationship, on the other hand, proved long-term and fruitful though not without blemish. With his elevation to the earldom of Worcester in 1589, Herbert now controlled large areas of Wales. As such, it was essential that Elizabeth maintained positive relations with him so that he would manage that remote section of the kingdom to her benefit. Herbert later served as master of the horse and on the Privy Council, offices which reflected the queen's approval, support, and trust. ${ }^{93}$ Though he had been instructed in his youth in the reformed religion, rumours abounded that Lady Katherine had converted to the Roman faith. ${ }^{94}$ This gossip the queen ignored, possibly due to both the Somerset and Hastings families' loyal service to the crown. ${ }^{95}$ On the whole, Herbert held more political value to the queen than Oxford and his court career reflected that. Although the queen's supportive involvement in the Herbert-Hastings marriage returned positive results, it was ineffectual in the Oxford-Cecil marriage. And yet her efforts to convert young Catholic nobility to Protestantism through involvement in their marriages would continue.

\footnotetext{
89 Kinney, ed., 119; T. B. Howell, ed., Cobbett's Complete Collection of State Trials, vol. 1 (London: R. Bagshaw, 1809), 1166, 1250, 1335; ODNB, s.v. "Vere, Edward de, seventeenth earl of Oxford."

90 Cokayne, ed., vol. 10, 252; Pearson, 173.

91 Merton, 268; Kinney, ed., 34. Trentham served as a maid of honour from 1582 to 1591.

92 Pearson, 171; N. M. Fuidge, "TRENTHAM, Thomas I (1538-87), of Rocester, Staffs.," The History of Parliament, accessed 29 November 2019, http://www.historyofparliamentonline.org/volume/1558-1603/member/trenthamthomas-i-1538-87. The queen's involvement in the Oxford-Trentham marriage has been imputed. A mark of honour, Elizabeth of Oxford later carried the queen's train at the St. George's Feast in 1600. See William Paley Baildon, ed., Les Reportes del Cases in Camera Stellata 1593 to 1609 ([London]: Privately Printed, 1894), 111.

93 Kinney, ed., 4, 14, 134.

94 Baildon, ed., 228.

95 ODNB, s.v. "Somerset, Edward, fourth earl of Worcester;" ibid, s.v. "Hastings, Henry, third earl of Huntingdon."
} 


\section{Cumberland-Russell and Wharton-Clifford, 1577}

On an early summer's day in June 1577 two young couples celebrated their double wedding at St. Saviour's Church in Southwark. ${ }^{96}$ It was a royal occasion due to Queen Elizabeth's attendance. George Clifford, third earl of Cumberland, married Margaret Russell, daughter of the second earl of Bedford, while Cumberland's sister Frances wed Philip Wharton, third baron Wharton. St. Saviour's stood "at the oldest crossing-point of the River Thames" which linked the open fields of the south bank to the bustling city of London-two very different worlds. ${ }^{97}$ In a similar way, the Cumberland-Russell and Wharton-Clifford double wedding joined opposing sides when it allied the Cliffords with the Whartons, northern with southern, and old Catholic traditions with the new Elizabethan Protestantism. ${ }^{98}$

The Cliffords, Whartons, and Russells were also drawn together by wardship. ${ }^{99}$ Both raised in northern England and in the Catholic faith, Cumberland and his sister became royal wards at the death of their father in 1570 . The young earl's guardianship and education passed to Bedford, a southern Protestant magnate and devoted servant of the queen. ${ }^{100}$ But even before the death of Cumberland's father, his parents had arranged for him to marry one of Bedford's daughters. ${ }^{101}$ Though a practicing Catholic, Cumberland's father supported the queen during the Northern Rebellion and sought to align himself with the leading Protestants in the Elizabethan court including Bedford and Leicester. ${ }^{102}$ It was a shrewd decision by the Cliffords to link their family with a rising Protestant courtier and, through him, restore their ties with the monarch. ${ }^{103}$ By the means of marriage, Bedford would extend his sphere of influence and his Protestant ideals to the north, a move undoubtedly welcomed by the queen. The Catholic baron Wharton was also a royal ward from the north of England. With the 1572 death of

\footnotetext{
${ }_{96}$ Cole, 190.

${ }^{97}$ Southwark Cathedral, "Our History," accessed 2 December 2019, https://cathedral.southwark.anglican.org/ about/our-history/. See also Samuel Pepys, Diary of Samuel Pepys, ed. J. Smith, vol. 1 (London: J. M. Dent \& Sons Ltd, 1908), 389.

98 Spence, 32.

99 See $C P R, 1578-1580,215$.

100 CPR, 1569-1572, 396; Spence, 30-31; George C. Williamson, George, Third Earl of Cumberland (1558-1605): His Life and His Voyages (Cambridge: Cambridge University Press, 1920), 5-6.

101 Williamson, 11.

102 ODNB, s.v. "Clifford, Henry, second earl of Cumberland."

103 CSPSp, 1568-1579, 158, 183.
} 
his father, a "known papist," recusant, and former privy councillor to Mary I, Wharton's kinsman Thomas Radcliffe, third earl of Sussex, a southerner, and loyal cousin of the queen, assumed his guardianship. ${ }^{104}$ As Wharton's guardian, it is likely that Sussex arranged the young baron's marriage to Lady Frances. The Wharton-Clifford marriage was a peace-making match, the two families having had long-standing disagreements over the administration of Westmorland, their joint sphere of influence. ${ }^{105}$ It was one of only three Catholic intra-denominational marriages which had the queen's support. ${ }^{106}$

The events which occurred in northern England from the late 1560s to the early 1570s were destabilising. As a result, the importance of bringing the future generation of northern noble leadership to the south and under the influence of pro-monarch, Protestant courtiers was critical.107 Advocated and patronised by the crown, the Cumberland-Russell and Wharton-Clifford marriages were exercises in peace, conformity, and the extension of Protestantism to the Scottish border. That Elizabeth made a personal appearance at the double wedding ceremony signalled her approval and support. But such an illustrious beginning to adulthood, in the end, gave way to what was sparse monarchical patronage, though it does appear that the monarch-noble ties remained intact.

Elizabeth's participation in and support of noble marriages in the 1560 s and 1570s conveyed her official policy of bolstering Protestantism in England as well as her unofficial policy of converting Catholic nobility to the reformed religion through marriage. Her unwritten religious agenda likely derived not only from dangerous interaction with her half-sister Mary, but also Catholic plotting against her regime. At the same time, it reflected the silent workings of the royal prerogative. She grasped the opportunity to back the 1565 Warwick-Russell marriage as a means of advocating her religious programme. Through the earl of Warwick, Protestant domination was achieved at the local government level in

${ }^{104} C P R, 1572-1575,231$. Thomas Wharton, second baron Wharton, was a "committed Catholic." See ODNB, s.v. "Wharton, Thomas, second Baron Wharton."

105 Spence, 24, 32; ODNB, s.v. "Wharton, Thomas, first Baron Wharton;" ibid, s.v. "Clifford, Henry, second earl of Cumberland."

106 Three Catholic intra-denominational marriages had Elizabeth's imputed support: 1566 Southampton-Browne, 1571 Paget-Newton, and 1577 Wharton-Clifford.

107 Spence, 32. 
Warwickshire. Likewise, she seized the chance to participate in and support interdenominational marriages between northern, Catholic noblemen and predominantly southern, Protestant brides. Her involvement had multiple aims: to further Protestantism among the northern nobility-to "wean... [them] from Popery" - to establish closer, pro-monarch connections between the northern nobility and the crown, and to extend the influence of the southern, Protestant court into the north. 108 These noble weddings gave Elizabeth an opening to demonstrate her solidarity with Protestant families like the Cecils, Hastings, and Russells who upheld the religious settlement and national church and also show tolerance of upper-level Catholic nobility. Close association with loyal, promonarch Protestant families made the young Catholic noblemen more acceptable within the Elizabethan court. The taint of Catholicism became diminished; Elizabeth's presence at the weddings confirmed this fact.

Interestingly, little information on the above-illustrated marriages appears in state papers, corroborating the silent, unofficial nature of the Elizabethan government's process of converting Catholic aristocracy to Protestantism through marriage. The French and Spanish ambassadors, however, had much to report to their governments at the event of the Oxford-Cecil and Herbert-Hastings double wedding. ${ }^{109}$ Spanish ambassador Guerau de Spes informed Philip II that

Lord Burleigh is celebrating with great festivity at the palace, the marriage of his daughter with the earl of Oxford. The son of the earl of Worcester is married also to the sister of the earl of Huntington, which means taking two families away from the Catholics. ${ }^{110}$

The implications of the interdenominational marriages, the incorporation of potentially key Catholic noblemen of the Elizabethan court into powerful, promonarch Protestant families, was alarming to the Catholic ambassador. Guerau de Spes's statement suggests that he believed that Catholic noble families' influence was being nullified, that they would become unable to support the Catholic cause in England. His dispatch provides evidence of Elizabeth's unwritten agenda which involved a systematic and strategic absorption of Catholic noble families into Protestant ones to diminish Catholic influence.

108 Baildon, ed., 228; Spence, 24.

109 Salignac, vol. 4, 94, 315, 319; CSPSp, 1568-1579, 358.

110 CSPSp, 1568-1579, 358. 
The system of wardship also played a part in weakening Rome's impact when young, Catholic noble wards became inculcated in the reformed religion by their Protestant guardians. Hurstfield has noted that Catholic noble wards Oxford, Wharton, Philip Howard, thirteenth earl of Arundel, and Henry Wriosthesley, third earl of Southampton, were educated under Burghley's staunchly Protestant guardianship. ${ }^{111}$ Cumberland received Protestant instruction under Bedford and John Whitgift, later archbishop of Canterbury. ${ }^{112}$ Lord Herbert was also taught by Whitgift and Wharton likely obtained Protestant tuition in Sussex's care. ${ }^{113}$ Afterwards, the marriages of these wards and other Catholic noblemen like Herbert were carefully managed to ensure they were agreeable to the crown and nearly always to a Protestant bride. ${ }^{114}$

Elizabeth's support of the interdenominational marriages of Oxford, Herbert, and Cumberland revealed how much "the marriages of the younger earls were of importance... to the crown, to ensure continuation of the young Protestant state." But of note is that none of these noblemen, apart from Herbert, achieved the position and influence that their upper-level noble rank would have predicted. ${ }^{115}$ Royal patronage did not result in influential offices but rather ceremonial or minor military ones-0xford held the hereditary position of lord great chamberlain, 116 Cumberland became the queen's champion, 117 Southampton's appointment as general of the horse by the second earl of Essex was cancelled by the queen, ${ }^{118}$ and Wharton served as a justice of the peace and held a military position in the north. ${ }^{119}$ This suggests that their Catholic backgrounds continued to hinder the queen's belief in their loyalty despite her outward appearance of approval; her patronage of them had limits. The Spanish ambassador's fear of a loss of Catholic influence was ultimately justified as these noblemen never made much of an impact on the Elizabethan stage.

\footnotetext{
111 Hurstfield, Queen's Wards, 249, 254-255.

112 Baildon, ed., 228; Spence, 23.

113 Baildon, ed., 228.

114 Southampton refused the ward's marriage offered to him by Burghley and later married clandestinely. See Hurstfield, Queen's Wards, 142, 251; ODNB, s.v. "Wriothesley, Henry, third earl of Southampton."

115 Hurstfield, Queen's Wards, 254-255, 259; Pearson, 15.

116 Kinney, ed., 119.

117 ODNB, s.v. "Clifford, George, third earl of Cumberland."

118 Cokayne, ed., vol. 12/1, 128.

119 Wharton was a high commander in York in 1599 and also served as a JP for Cumberland and several other counties. See Cokayne, ed., vol. 12/2, 600-601; Bryan Dale, The Good Lord Wharton: His Family, Life, and Bible Charity, new ed., (London: Congregational Union of England and Wales, 1906), 24-27.
} 
The active, though unstated, policy of transforming England's Catholic nobility into Protestants through marital alliances is supported by statistics from the database. ${ }^{120}$ There were only three interdenominational marriages in the 1560s and Elizabeth did not participate in any of them. Significantly, at least one member of each of these three couples would have ties to the 1569 Northern Rebellion. ${ }^{121}$ As a result, the move to wed Catholics with Protestants can be viewed as a consequence of the Northern Rebellion and subsequent Catholic plotting. Elizabeth was unable to eradicate completely Catholicism from England in an official way, though punitive measures against Catholics grew in severity during her reign. ${ }^{122}$ But, through the royal prerogative she could manipulate it through effective management of and involvement in marriages. Next to her plural prerogative of wardship, noble unions provided her with the opportunity to entrench more deeply Protestantism and the Church of England by promoting interdenominational alliances. The queen's outward approval and support avoided alienation of her Catholic nobility and aimed at preventing another Northern Rebellion. ${ }^{123}$ It was a long-term enterprise, however, the results of which would take generations to materialise. These factors are why the queen's presence at the Oxford-Cecil and Herbert-Hastings double wedding and, later in the decade, the Cumberland-Russell and Wharton-Clifford double wedding was critical: it delivered a strong message of support not only to her fellow Protestants but also to Catholics that conformity was necessary for royal favour to continue.

\section{Jacobean case studies}

Prior to 1603 James, as king of Scotland, became involved in and supported numerous noble marriages which would increase stability, obedience to, and alignment with the crown. As part of this endeavour, he advocated multiple intraand interdenominational weddings which upheld his religious policy. James's agenda sought to strengthen the Protestant Church of Scotland and to secure and maintain his position as the leader of that institution. To achieve this, he had to work with Catholics and moderate to extreme Protestants alike which is perhaps

\footnotetext{
120 Pearson, 29.

121 These interdenominational marriages in which Elizabeth apparently did not participate were the 1562 PercyNeville, 1564 Westmorland-Howard, and 1567 Norfolk-Dacre.

122 SR, vol. 4, 526-531, 657-661, 704-708, 841-846. See also Ian Mortimer, The Time Traveler's Guide to Elizabethan England (New York: Penguin Books, 2012), 61.

123 Spence, 32.
} 
why he supported more interdenominational marriages than intradenominational. Indeed, as Lockyer has observed, James "longed to restore unity to Christendom by means of interlocking marriage alliances." 124 In this way he was different from Elizabeth who rarely patronised openly Catholic subjects. James's tolerance of Catholics made him, at times, deeply misunderstood in England. But his purpose as king and head of ultimately two national churches was enforcement of his authority and a moderate Protestantism, both of which he attained. Furthermore, once king of England, James desired a union of his kingdoms as previously discussed. When administrative unification collapsed in the English Parliament, the number of Anglo-Scottish marriages increased. This phenomenon was a real and concerted effort on James's part to see the union take place, if not on a legislative level, then on a societal level, to guarantee the Briticisation of the future. James pursued both the religious and Anglo-Scottish union policies through his supportive involvement in the marriages of his nobility as the following cases reveal.

\section{Huntly-Stewart, 1588}

Several years into his personal rule of Scotland, King James VI became involved in a noble marriage which afforded him the chance to express his desires for loyalty and greater kingdom cohesion. He gave overt support and encouragement to an alliance between George Gordon, sixth earl of Huntly, who "ruleth all in the north at his pleasure," and the French Catholic Lady Henrietta Stewart.125 Lady Henrietta was the daughter of Esmé Stuart [Stewart], sixth seigneur d'Aubigny and first duke of Lennox, James's cousin and adviser. The marriage was likely contracted in 1581 as a means for the French-born Lennox to gain influential Scottish backing since he had no local kin network upon which to rely for support.126 According to Ruth Grant, it was around this time that James began "to flirt with opposing sides," shifting "from the exclusively Anglo-Protestant policy of the preceding regencies," to a broader approach which included French

\footnotetext{
124 Lockyer, "James VI/I," 12.

125 TNA, SP 52/47/119; Bannatyne Club, The Bannatyne Miscellany, vol. 1 (Edinburgh: The Bannatyne Club, 1827), 57; Ruth Grant, "Politicking Jacobean Women: Lady Ferniehirst, the Countess of Arran and the Countess of Huntly, c.15801603," in Women in Scotland c.1100-c.1750, ed. Elizabeth Ewan and Maureen M. Meikle (East Linton: Tuckwell Press, 1999), 100.

126 Ruth Grant, "George Gordon, Sixth Earl of Huntly and the Politics of the Counter-Reformation in Scotland, 15811595," (Ph.D. diss., University of Edinburgh, 2010), 40-41.
} 
and Spanish input. 127 With Huntly as a kinsman, the king could rely upon the Gordons' formidable northern, Catholic, and pro-Mary, queen of Scots, status as a counterweight to the influence of the kirk and other southern, Protestant and proEnglish nobles. ${ }^{128}$ In addition, a familial connection between the Catholic Huntly and the Protestant James publicised the king's desire for greater religious accord and emphasis on fidelity. Thus, the Huntly-Stewart marriage provided James with opportunities to balance his most dominant opposing factions, to forge upper-level noble ties to the monarch, and to pursue his moderate religious agenda which stressed harmony. Each was for the purpose of fostering more expansive royal authority and greater kingdom stability.

As Lady Henrietta was only eight years old at her betrothal, it is not surprising that while awaiting his bride's coming of age, Huntly "became greatly enamoured" with Anne Ker, daughter of Sir Thomas Ker of Ferniehirst, Roxburghshire, a formidable Catholic Border laird. A marriage between Huntly and Ker was suggested in 1583. A Huntly-Ker union would have joined two strong Catholic families and extended Huntly's influence from the Highlands to the Borders. James, however, expressly forbade the alliance. He asserted his authority to determine a nobleman's marital partner, though Huntly was neither a royal ward nor a member of the king's household. ${ }^{129}$ Huntly, pressed by an insistent James to honour his contract with Lady Henrietta, agreed not to continue the relationship with Ker. Mary, queen of Scots, writing in 1584 from her exile in England, supported the earl's marriage to Lady Henrietta and desired James to "intervene" to ensure its "accomplishment."130

By 1586, James was very eager for the Huntly-Stewart marriage to occur. He urged Parliament to award Huntly 5,000 merks to cover the expense of bringing his bride-to-be to Scotland from France where she was living. ${ }^{131}$ This accomplished, it was only after the kirk forced Huntly and Lady Henrietta to sign confessions of faith stating they were Protestants that the wedding eventually took

\footnotetext{
127 Grant, “George Gordon," 42-43.

128 BL, Cotton MSS, Caligula D/I fol. 227; Grant, “George Gordon,” 44; Alison Cathcart, “Crisis of Identity? Clan Chattan's Response to Government Policy in the Scottish Highlands c. 1580-1609," in Fighting for Identity: Scottish Military Experience c. 1550-1900, ed. Steve Murdoch and Andrew Mackillop (Leiden: Brill, 2002), 171; CSPSC, 1571-1574, xviii. 129 Charles Gordon, ed., The Records of Aboyne, MCCXXX-MDCLXXXI (Aberdeen: Milne and Hutchison, 1894), 501, 503. 130 TNA, SP 53/14/108.

131 RPC, 1585-1592, 103; Gordon, ed., 503; ODNB, s.v. "Gordon, George, first marquess of Huntly."
} 
place on 25 July 1588 at Holyroodhouse chapel. ${ }^{132}$ James gave away the bride himself, signalling not only his personal involvement in the match and fatherly role, but also the divine and royal sanction it received. Moreover, James's participation heralded the establishment of a patron-client relationship between himself and the united Gordon and Stewart families as represented by Huntly and Lady Henrietta. This patronage heralded the king's hierarchical supremacy as well as his expectations of loyalty and reciprocation from the couple. The king further demonstrated support by granting Huntly the commendatorship of Dunfermline and by later appointing him captain of the guard. ${ }^{133}$

The James-Huntly-Stewart patron-client relationship was only temporary. Within a year of the marriage, Huntly's involvement in multiple schemes against both the king and Church of Scotland, which included having contact with Spain and corresponding with Catholic recusants, was discovered. ${ }^{134}$ When documents confirming Huntly's support for a Spanish invasion of England were found in early 1589, James seemed disillusioned: "Are these the fruits of your new conversion?"135 Huntly was detained briefly as punishment but he later abandoned the king during a rebellion in Edinburgh and participated in the Brig o' Dee revolt. Both acts angered James and caused the earl to lose his captaincy position. Huntly was also involved in the "Spanish blanks" affair, but was forgiven until the suppression of his final rebellion, raised in favour of Catholicism, sent him into exile in 1595. It was Lady Henrietta's close friendships with James and Queen Anne which helped to ensure Huntly's return to favour time and again. By 1599 Huntly managed to return to favour, becoming a privy councillor and being raised to the rank of marquess, an elevation that arrived eleven years after James had promised and is, thus, reminiscent of his belated commitment to Alexander, lord Spynie, described in chapter two. ${ }^{136}$ But he did not play a significant role in politics again. James would later remark, "I can never hate the Person I have once placed

\footnotetext{
132 BL, Cotton MSS, Caligula D/I fol. 317; David Moysie, Memoirs of the Affairs of Scotland (Edinburgh: The Bannatyne Club, 1830), 69; Juhala, 101; ODNB, s.v. "Gordon, George, first marquess of Huntly."

133 RPS, 1587/7/83; BL, Cotton MSS, Caligula D/I fol. 182; Juhala, 310.

${ }_{134}$ Ruth Grant, "The Brig o' Dee Affair, the Sixth Earl of Huntly and the Politics of the Counter-Reformation," in The Reign of James VI, ed. Julian Goodare and Michael Lynch (East Lothian: Tuckwell Press, 2000), 104.

135 TNA, SP 52/43/15; ODNB, s.v. "Gordon, George, first marquess of Huntly."

136 Ruth Grant, "Friendship, Politics and Religion: George Gordon, Sixth Earl of Huntly and King James VI, 1581-1595," in James VI and Noble Power in Scotland 1578-1603, ed. Miles Kerr-Peterson and Steven J. Reid (London and New York: Routledge, 2017), 70-71, 72.
} 
my Affection upon. I may hate some Vices of his, which may lessen my Favour, but never bend my Heart against him, unless he undoes himself."137

The James-Huntly-Stewart patron-client relationship established at the time of the wedding collapsed, despite the tremendous royal patronage and favour shown. James's supportive involvement in this marriage was a failure. Was this because Huntly "was hot-headed and prone towards rebellions and subversive plots," as Amy Juhala has described?138 Did the kirk's requirement and the king's tacit agreement that Huntly and Lady Henrietta convert to Protestantism play a part in the defiance? Or, did the instability of the James-Huntly-Stewart monarchnoble relationship speak more broadly to the struggles James faced in balancing his own authority with that of Scotland's powerful magnates? ${ }^{139}$ During his early reign of Scotland, James continually had to overlook noble transgressions to avoid disaffecting his most influential subjects. Along with Huntly, prior to 1603 James forgave, sometimes only temporarily, other influential noblemen for various transgressions including William Ruthven, first earl of Gowrie, James Erskine, second/eighteenth earl of Mar, Francis Stewart, first earl of Bothwell, and Ludovick Stuart, second duke of Lennox. He regularly re-forged bonds with offending nobles, highlighting the importance of the monarch-noble connection and the critical role it played in extending crown authority and maintaining stability in Scotland. Alan MacDonald has described this situation:

before 1603, he [James] was unable to gain the upper hand in his dealings with the Catholic nobles. They possessed enough military strength to remain unthreatened by the crown and were thus able to remain firmly undealt with, in spite of treasonous dealings with Spain. King James acted against them occasionally, never very harshly... He did not see them as a genuine threat. ${ }^{140}$

Indeed, James may not have perceived Huntly as a true threat to his sovereignty. However, when considering the earl's strength and following it is understandable that the king was against his proposed marriage to Anne Ker, daughter of one of the most powerful Border lairds. ${ }^{141}$ A Huntly-Ker marriage would have extended Huntly's already considerable sway into the Borders, rather than keeping it

$137 \mathrm{JPC}, 14$.

138 Juhala, 100.

139 CSPSc, 1589-1593, xxiii.

140 MacDonald, 50.

141 Cathcart, 182. 
confined to the Highlands as the Huntly-Stewart marriage did. Thus, James's close management of the Huntly-Stewart marriage, ensuring that it did take place rather than become derailed, effectively limited Huntly's sphere of influence while it also made him a kinsman of the king. Furthermore, Huntly's religious faith was of less importance than his loyalty. James repeatedly bestowed patronage on the wayward earl due to the vast landholdings, influence, and, therefore, political importance he held: "for a lord marshalling the support of an entire region could never be discounted or taken lightly."142

Mar-Stewart, 1592

Four years after the Huntly-Stewart union James personally organised the wedding of Lady Henrietta's sister Lady Mary Stewart to the Protestant John Erskine, eighteenth/second earl of Mar. ${ }^{143}$ Before the marriage could take place, however, Mar had "to win Mistress Mary Stewart, to embrace the [Protestant] religion faithfully or else to forbear to take her to his wife."144 Lady Mary obliged and the wedding was celebrated on 7 December $1592 .{ }^{145}$ Through this matchmaking James took the opportunity to forge a peace-making alliance which bound historic enemies: the staunchly Catholic, pro-France Stewarts to the firmly Protestant, pro-England Erskines. It also brought Mar and Huntly together. Now brothers-in-law united by kinship ties, Mar acted as a strong counter to Huntly's and other Catholic nobles' influence within James's court. ${ }^{146}$ In contrast to Huntly, however, Mar continually maintained James's confidence and goodwill despite his participation in the Ruthven and Stirling Raids of the 1580s. ${ }^{147}$ He served the king as a privy councillor, the custodian of Prince Henry, an administrator, and ambassador. Mar followed James south once he became king of England and later acted as treasurer of Scotland. The James-Mar-Stewart patron-client relationship was successful and enduring.

James balanced conflicting political and religious groups with his arrangement of the Mar-Stewart marriage just as his promotion of the Huntly-

\footnotetext{
142 Grant, "George Gordon," 40.

143 ODNB, s.v. "Erskine, John, eighteenth or second earl of Mar;" Paul, ed., vol. 5, 356. See also TNA, SP 52/49/13.

144 TNA, SP 52/49/19.

145 CP, Vol. 169/9.

146 BL, Cotton MSS, Caligula D/I fols. 251, 389; ODNB, s.v. "Erskine, John, eighteenth or second earl of Mar."

147 Juhala, 95.
} 
Stewart marriage had offset the Protestant, pro-English interests at court. Through these marriages, the king seized opportunities to stabilise the court and to express overtly his desire for harmony and allegiance to the monarch. ${ }^{148} \mathrm{He}$ worked to subdue powerful factions and bring them to a greater level of obedience. In the process, James bound rival kin groups together and to himself, rather than to their respective religions. Brown has observed that, "because of their public roles, the religious faith of the nobility, like that of kings" became an important political consideration; it could shape the monarch-noble relationship. ${ }^{149}$ But, James, through his determined organisation of the Huntly-Stewart and Mar-Stewart unions, communicated a clear and significant message: religion was subordinate to loyalty and service to the crown.

\section{Essex-Howard, 1606}

After 1603, James, as king of England, continued endorsing noble marriages to bring greater stability to his court. To this end, he eagerly supported the alliance between royal ward and member of Prince Henry's household Robert Devereux, third earl of Essex, and Frances Howard, daughter of Thomas, first earl of Suffolk and lord chamberlain. ${ }^{150}$ The Essex-Howard marriage, like the HerbertVere marriage, typified the early Stuart English court wedding and James's supportive approach to noble-marriage involvement. It was a multi-day event attended by the king which comprised lavish entertainments. ${ }^{151}$ Celebrated over two days from 5 to 6 January 1606, the more private religious ceremony took place at the king's chapel at Whitehall, "the Kings Majesty giving her [Lady Frances] in marriage."152 The chapel service gave way to a wedding banquet teeming with the highest level of society. This was followed by a Ben Jonson masque entitled Hymenæi which commemorated the marriage. ${ }^{153}$ The nuptial celebrations, conducted under the king's approving eye, heralded the new bond between the

\footnotetext{
148 James had a similar goal following the 1589 Brig o' Dee revolt. See TNA, SP 52/46/7.

149 Brown, Noble Power, 3.

150 Sources vary as to the architect of this alliance. For James as the broker of the marriage see Bellany, 51. For Salisbury as the instigator see Arthur Wilson, The History of Great Britain (London: Richard Lownds, 1653), 55; Leeds Barroll, Anna of Denmark, Queen of England (Philadelphia: University of Pennsylvania Press, 2001), 108; Somerset, 14. Alternatively, the Howard family may have desired the marriage and convinced the king to "sponsor" it. See ODNB, s.v. "Devereux, Robert, third earl of Essex."

151 Wilson, 55.

152 Rimbault, ed., 161.

153 Ben Jonson, Hymenæi: or The Solemnities of Masque, and Barriers (London: Valentine Sims for Thomas Thorp, 1606), 1. See also idem, Ben Jonson: The Complete Masques, ed. Stephen Orgel (New Haven and London: Yale University Press, 1969), 94; Curran, Marriage, 9, 43.
} 
Devereux and Howard families as represented through the lawful and bodily joining of Essex and Lady Frances. It also clearly signalled the establishment of a monarch-noble patron-client relationship which both recognised the families' alliance and served to focus their attention and loyalty to the crown. The festivities also hinted at the king's dream of "Britain" and were, thus, a nod to the king's Anglo-Scottish union plans. ${ }^{154}$ Kevin Curran has remarked that the Essex-Howard wedding was "the first large-scale manifestation of the king's policy of political reconciliation," as well as "the first clear-cut opportunity to link a personal union with the British national Union."155

James took full advantage of the opportunities the Essex-Howard marriage presented to his monarchy. Beyond the Anglo-Scottish union, his involvement represented his endorsement and support of the young Essex, a devout Protestant like his father. It also signalled his approbation of the Howards, a family marred by treason and Catholic sympathies under Elizabeth. ${ }^{156}$ Although Lady Frances's father was likely not Catholic, her mother and her uncle Henry Howard, earl of Northampton, were crypto-Catholics. ${ }^{157}$ The king's open consent became a statement to his new English subjects that, as in Scotland, loyalty and compliance were paramount while religious views were of lesser importance. Because this peace-making wedding joined two families from opposing ends of the religious spectrum, it showed James operating as he had as king of Scotland prior to 1603 with the Mar-Stewart wedding-he ended disagreements with marital alliances that brought accord to the court and country. Nonetheless, James's embrace of Catholic courtiers and his message of solidarity were not well-received by everyone. When Parliament convened two weeks after the Essex-Howard wedding, the House of Commons wished "to move his majesty that he would make a public proclamation, in showing his detestation against Popery and their adherents."158

\footnotetext{
154 Birch and Williams, eds., vol. 1, 42; Loughlin, 839-840; Jonson, Complete Masques, 89.

155 Hymenæi begins with a song expressing this idea of union. See Jonson, Complete Masques, 77; Curran, Marriage, Performance, and Politics, 47.

156 Robert Codrington, The Life and Death, of the Illustrious Robert Earle of Essex (London: F. Leach, for L. Chapman, 1646), 6; Curran, Marriage, 44-45.

157 ODNB, s.v. "Howard [née Knyvett; other married name Rich], Katherine, countess of Suffolk;" ibid, s.v. "Howard, Henry, earl of Northampton."

158 Birch and Williams, eds., vol. 1, 45.
} 
Despite their union's indisputable regal backing, Essex and Lady Frances simply were not compatible in spite of cohabitation since 1609.159 They had been "too young to consider" the reality and permanence of marriage, "but old enough to consent" to the ceremony itself. ${ }^{160}$ Their marriage remained unconsummated and by 1612 it was over; the James-Essex-Howard patron-client relationship collapsed.161 Essex, who had once had the king's good will, was out of favour and the court now revolved around the earl of Somerset, James's then-favourite. Lady Frances submitted an official annulment request on 17 May $1613 .{ }^{162}$ James, employing the royal prerogative as supreme governor of the church, "set the course now in prosecution," and appointed a High Commission panel headed by George Abbott, archbishop of Canterbury, to hear the case. ${ }^{163}$

By June some courtiers were surprised to realise that the annulment proceedings would eventually pave the way for Lady Frances's marriage to Somerset. 164 Ironically, the failure of the Essex-Howard union had been foreshadowed during the performance of Hymenæi when the character Hymen urged the festivities' conclusion so that the marriage could be consummated. ${ }^{165}$ The early modern assumption was that the female "virginal body" was "naturallyand divinely-oriented towards marital intercourse." If a marriage was not soon consummated, the female was likely "to become infected with a pathological and uncontrollable need for said intercourse," and seek illicit relationships to fulfil that need. ${ }^{166}$ Because the Essex-Howard union was never consummated, it was believed that Lady Frances and Somerset pursued their affair prior to her marriage's official termination. 167 It was also assumed that the court proceedings would be quickly finalised, but that was not the case.168 Anne Somerset has suggested that James himself sponsored the nullity lawsuit because the Howards, uncertain of the outcome, would not have attempted it otherwise: "what was done,

159 David Lindley, “Embarrassing Ben: The Masques for Frances Howard.” English Literary Renaissance 16 (1986): 346. 160 Wilson, 55.

161 Howell, ed., vol. 2, 786; Bellany, 52.

162 TNA, SP 14/74/118.

163 HMC, Mar and Kellie, vol. 2, 51; Howell, ed., vol. 2, 785, 814

164 TNA, SP 14/74/2, 20; Bellany, 52-53.

165 Jonson, Complete Masques, 88.

166 Loughlin, 836.

167 TNA, SP 14/74/20; Rymer, 515; Somerset, 124; John Harington, Nugæ Antiquæ, ed. Henry Harington, vol. 1 (London: Vernor and Hood, 1804), 390-397.

168 In June 1613, Chamberlain wrote twice that the divorce proceedings would soon be concluded. See TNA, SP $14 / 74 / 2,20$. 
was performed by the king's direction."169 Ultimately, substantial monarchical intervention was required. The king personally shouldered the responsibility of having the legally binding marriage contract between Essex and Howard undone, a union which he had so ardently and openly supported. All was to ensure the marriage of his favourite Somerset took place.

James's interference pressured the court to find his preferred outcome. ${ }^{170}$ As sovereign and supreme governor of the church, it probably seemed that it was a request within his authority to command. He wrote in The Trew Law of Free Monarchies that

For albeit the king make daily statutes and ordinances, enjoining such pains thereto as he thinks meet, without any advice of Parliament or estates; yet it lies in the power of no Parliament, to make any kind of Law or Statute, without his Sceptre be to it, for giving it the force of a Law. ${ }^{171}$

Based on this statement, James believed that it was within his right to make decisions without consulting Parliament or the estates, including decisions relative to the church. In late July James met with the High Commission judges. ${ }^{172}$ Discovering that they were divided in their opinions, he added four more judges who, as it transpired, were clearly amenable to the king's view. ${ }^{173}$ By August, John Chamberlain was reporting to Sir Dudley Carleton that "the King's inclination is like to be for the dissolution."174 The recently-enacted 1604 canons upheld that couples could be divorced but remarriage could not occur until one party or the other died. ${ }^{175}$ Thus, annulment of the Essex-Howard marriage was essential for the Somerset-Howard marriage to proceed.

As court deliberations continued, James sent an "express commandment" to the High Commission, "that in opining they should not argue nor use any reasons, but only give their assent or dissent, and in the sentence there is no cause expressed but in these terms propter latens et incurabile impedimentum (a latent

\footnotetext{
169 Somerset, 124; Howell, ed., vol. 2, 819.

170 Howell, ed., vol. 2, 815.

$171 \mathrm{JPW}, 74$.

172 HMC, Report on the Manuscripts of the Duke of Buccleuch and Queensbery, Preserved at Montagu House, vol. 1 (London: Printed for H. M. Stationery Office by Eyre and Spottiswoode, 1899), 140 [hereafter HMC, Buccleuch].

173 HMC, Mar and Kellie, vol. 2, 53; TNA, SP 14/74/100.

174 TNA, SP 14/74/100.

${ }^{175} A C, 407$
} 
and incurable barrier)."176 In essence, the king declared what the judges' finding should be and, unsurprisingly, the majority vote required for a decree of annulment materialised. The final verdict was announced on 25 September 1613 by the bishops of Winchester and Rochester, rather than Abbott, their superior and chair of the commission. ${ }^{177}$ Lack of support for the annulment from Abbott and others attested to the dissent within the proceedings and the discomfort at issuing the decision. ${ }^{178}$ It is unclear whether the allegations that the marriage was never consummated or that Essex was unable personally to consummate the marriage were "true or feigned." 179 These uncertainties may have been why some of the judges did not wish to proceed with the suit. James himself expressed some regret over the situation, speaking "against these marryings of young couples, before they be acquainted one with another," but that did not prevent him from stacking the court in his and Lady Frances's favour to see their desired verdict delivered. ${ }^{180}$

The Essex-Howard marriage and its subsequent dissolution exposed James's fully embrace and employment of plural and royal prerogatives and patronage, all of which were largely unregulated remits of his role. His plural prerogative of wards' marriages enabled him to become involved in the marriage. The gift of his presence at the wedding and overt support signalled the initiation of patronage between the monarch and noble couple who represented their respective families. The monarch-noble patron-client bond upheld the social hierarchy through its obligatory fidelity and reciprocation. Later, through the royal prerogative in his capacity as supreme governor of the church, James had the marriage annulled. It was a nullity with which five commissioners did not agree, but which guaranteed the king's expected result: a highly celebrated and symbolic Anglo-Scottish court wedding. His active management of the Essex-Howard annulment ensured that the Somerset-Howard wedding would take place.

In addition, while the Essex-Howard marriage can be connected to James's religious policy in that it joined traditionally Protestant and Catholic families, its dissolution can undoubtedly be connected with the Anglo-Scottish union. James's

\footnotetext{
176 TNA, SP 14/74/167.

177 TNA, SP 14/74/118. See also Howell, ed., vol. 2, 804.

178 HMC, Buccleuch, vol. 1, 140; Howell, ed., vol. 2, 786-804; Bellany, 53.

179 Chamberlain, vol. 1 444. See also Howell, ed., vol. 2, 789-794; Somerset, 117.

180 Howell, ed., vol. 2, 814.
} 
involvement in the Essex-Howard marriage had relayed a message of support, a pacifying gesture which returned the Devereuxs and Howards to the courtly fold and promoted accord between them. But his supervision of the marriage's annulment unambiguously revealed his determined use of the royal prerogative to guarantee that the Anglo-Scottish Somerset-Howard wedding would come to pass. Unhindered by the expertise and opinions of church leaders, James wanted to see England and Scotland united symbolically, even at the expense of Essex, who, in this situation, could perhaps be viewed as a symbol of England itself. The king issued a bold, if tacit, statement by personally managing the removal of "England" in the form of Essex, and inserting in its place "Scotland" as represented by Somerset, in marital connection with the English Lady Frances. Although Parliament had denied him his dream of Britain, James utilised what means remained to him-the royal prerogative-to see the two kingdoms united by another means. ${ }^{181}$

The Essex-Howard annulment and subsequent Somerset-Howard marriage, different manifestations of the royal prerogative, coincided with James's reduced cooperation with Parliament and the beginning of a more independent, personal rule. From this period, James began to depend largely on his favourite and prerogatives-those singular entitlements of the monarch. A result was the reduction of the English Privy Council's influence. Following the 1612 death of James's secretary of state, the earl of Salisbury, royal favourite Somerset became arch-manager of state affairs. Through him government business was conducted, patronage sought and granted. ${ }^{182}$ This powerful position placed Somerset only one step below the king in terms of authority and beneficence and displayed James's use of the royal prerogative to assert his independence from the Privy Council. ${ }^{183}$ Cuddy has suggested that James's overt support of his fellow Scots in the bedchamber was a response to the "failure of the English political establishment to embrace Union wholeheartedly."184 Altogether James's backing of the EssexHoward annulment, his support for the Anglo-Scottish Somerset-Howard marriage, and his subsequent investiture of power in this favourite were expressions of the

\footnotetext{
181 Cuddy, "Revival," 202-203; Levack, Formation, 181; Goodare, Government, 106.

182 Cuddy, "Revival," 208-209.

183 David Lindley, The Trials of Frances Howard (London and New York: Routledge, 1993), 83; Cuddy, "Revival," 173, 192, 211, 225.

184 Cuddy, "Revival," 203.
} 
royal prerogative. Each event was an action, absolutist in nature, aided by the royal prerogative which had the purpose of bypassing the authority of the High Commission court, Parliament, or the Privy Council, excluding them from judicial or government decision-making processes.

Hay-Denny, 1607

Years before the 1613 Somerset-Howard marriage presented in the introduction, James was already broadcasting his idea of Britain beyond the confines of Parliament, directly to his court.185 In this endeavour, he seized the chance to promote his fellow Scots by encouraging Anglo-Scottish marriages. ${ }^{186}$ Among the very first Anglo-Scottish noble marriages of James's reign of England was that of Charles Howard, first earl of Nottingham, to Lady Margaret Stewart, daughter of Scottish nobleman James Stewart, second earl of Moray, in September 1603.187 But the 1607 wedding between Scotsman Sir James Hay, first lord Hay, and the English Lady Honora Denny, daughter of Sir Edward Denny, first baron Denny, was among the most lavish of all the Jacobean, Anglo-Scottish court alliances. ${ }^{188}$ If the Essex-Howard marriage had hinted at James's desire for "cohesion at court" that would bring, as the king hoped, "domestic cohesion within the isle as a whole", then the Hay-Denny wedding unmistakeably expressed this message far and wide. ${ }^{189}$ Lady Honora, a wealthy heiress, was considered an excellent match for the 27-year-old Hay, a gentleman of the bedchamber and one of the king's favourite courtiers. ${ }^{190}$ Hay had been invited by James to join him on his journey southward to claim the English throne and had not long been in England when the king began arranging the match in 1604 as was his in loco parentis duty. ${ }^{191}$ This alliance saw James raising Hay's personal and financial standing and also offering incentives to Sir Edward to secure his agreement to the match. ${ }^{192}$

\footnotetext{
185 Curran, Marriage, 46, 62.

186 Brown, "Scottish Aristocracy," 569.

187 Lodge, 1838 ed., vol. 3, 40-41; Cokayne, ed., vol. 9, 786.

188 Lady Honora was either fifteen- or sixteen-years-old at the time of the marriage. See David Lindley, "Who Paid for Campion's 'Lord Hay's Masque'?," Notes \& Queries 26 (1979): 145.

189 CSPV, 1603-1607, 494; Curran, Marriage, 46.

190 TNA, SP 14/13/166; Nichols, James, vol. 2, 103; Cokayne, ed., vol. 3, 32.

191 CP, Vol. 188/148. The marriage was organised over several years as the bride reached a suitable age for marriage.

192 CSPD, 1603-1610, 149; Calendar of State Papers Relating to Ireland of the Reign of James I, ed. C. W. Russell and John P. Prendergast, vol. 12 (London: H. M. Stationery Office, 1874), 45; HMC, Calendar of the Manuscripts of Lord Sackville, vol. 1 (London: H. M. Stationery Office, 1940), 119. See also Lindley, “Who Paid?," 144-145.
} 
Both men were elevated to the peerage, ${ }^{193}$ while Parliament approved Hay's naturalisation as an English citizen. ${ }^{194}$ In addition, around the time of the wedding James agreed to pay Lord Hay's (as well as viscount Haddington's and the earl of Montgomery's) debts: "he [James] will this once set them free, and then let them shift for themselves."195 It was as good a beginning as any young courtier could hope for.

When the wedding day finally arrived on 6 January 1607, it was a spectacular one. ${ }^{196}$ James honoured Lord Hay and Lady Honora by allowing their marriage to take place in the King's Chapel at Whitehall. The king himself gave away the bride. His royal presence at the ceremony indicated that a patron-client relationship was duly established and acknowledged the joining of the Hay and Denny families. ${ }^{197}$ The highest level of early Stuart England society graced the extravagant wedding celebrations which included the staging of Thomas Campion's The Lord Hay's Masque in the Great Hall. ${ }^{198}$ The masque featured a clear message of union ${ }^{199}$ and the performance's dedication to Lord and Lady Hay emphasised their Anglo-Scottish marital alliance and what would be their "British" posterity. ${ }^{200}$ The James-Hay-Denny patron-client relationship was successful, ending only with Lady Honora's death in $1614 .^{201}$ Yet the king's support of Hay continued. In 1617, when Hay contracted another Anglo-Scottish marriage, this time to Lucy Percy, daughter of Henry, ninth earl of Northumberland, James attended the wedding feast and paid $£ 10,000$ towards expenses. ${ }^{202}$

James's manifest approval and support of the Anglo-Scottish Hay-Denny marriage had followed a disappointing parliamentary attempt at union in $1604 .^{203}$ In the face of this setback, the titles, property, and financial grants associated with

\footnotetext{
193 Cokayne, ed., vol. 4, 187; ibid, vol. 9, 768.

${ }^{194} L \mathrm{~J}$, vol. 2, 304-305; CJ, vol. 1, 225.

195 TNA, SP 14/26/79; CP, Pet. 1301.

196 CSPV, 1603-1607, 454, 456.

197 Rimbault, ed., 161.

198 Nichols, James, vol. 2, 105-121.

199 Thomas Campion, The Works of Thomas Campion, ed. Walter R. Davis (London: Faber and Faber, 1969), 208; Nichols, James, vol. 2, 107-109; Loughlin, 841-842; Curran, Marriage, 62.

200 Campion, 210.

201 At the time of his wedding, Hay was already master of the robes. He later became master of the great wardrobe in 1613 and was elevated to the English peerage as baron Hay of Sawley, Yorkshire, in 1615. See Roy E. Schreiber, "The First Carlisle: Sir James Hay, First Earl of Carlisle as Courtier, Diplomat and Entrepreneur, 1580-1636," Transactions of the American Philosophical Society 74 (1984): 1-202.

202 TNA, SP 14/94/16. In 1618 Lord Hay became viscount Doncaster and in 1622 he became earl of Carlisle.

203 Curran, Marriage, 62; idem, "Erotic Policy," 57-58.
} 
the Hay-Denny marriage brokering process revealed the importance the king placed upon the alliance. James's endorsement and promotion of the match were not merely displays of his authority and his in loco parentis right to manage a marriage. ${ }^{204}$ Instead, the incentives were critical elements he employed to ensure that the Hay-Denny marriage went forward so that he could continue to transmit his Anglo-Scottish ideal to the court and beyond. When Parliament reconvened in February 1607 after the Hay-Denny wedding, debate resumed on the "Instrument of Union."205 The instrument recommended that both ante-nati and post-nati English and Scottish subjects be naturalised as British citizens, as opposed to either English or Scottish. ${ }^{206}$ Ultimately, with Calvin's case the courts, rather than Parliament, determined that only post-nati subjects became British citizens, resulting in very few British subjects and all of them very young, three-years-old or less; not the king's preferred outcome. ${ }^{207}$ By May 1607 James's hope for a legal union of his two kingdoms was truly defeated and he gave up his plans. ${ }^{208}$

Based on the courts' post-nati decision, James's abandonment of the Britain idea, and the understanding that "British national identity was dependent on the birth of more children" as Curran has observed, the king escalated his support of Anglo-Scottish marriages. This act revealed his unwritten Briticisation policy. Curran has also indicated that the Anglo-Scottish marriage was "the political Union of England and Scotland on an individual scale while the offspring resulting from the marriage contribute[d] to a growing body of legally British subjects." 209 Moreover, the Briticisation policy was accomplished through the royal prerogative as the king disregarded Parliament's conclusion on union and sought to establish it himself.210 As a result, the intervening years between the 1607 Hay-Denny and the 1613 Somerset-Howard marriages saw a number of Anglo-Scottish noble weddings take place including the 1608 Cavendish-Bruce ${ }^{211}$ and Crichton-

\footnotetext{
204 Curran, Marriage, 62.

205 The instrument had already been read in the Commons in November 1606, prior to the Christmas adjournment. See CJ, vol. 1, 318-323.

206 This referred to subjects born before and after James's accession to the English throne on 24 March 1603.

207 Coke, vol. 4, 1-48.

208 Russell, James, 62; David Loades, The Cecils: Privilege and Power Behind the Throne (Kew: The National Archives, 2007), 237; Andrew Thrush, "On this Day: 21 November 1606: The proposed union between England and Scotland," The History of Parliament, accessed 7 December 2019, https://www.historyofparliamentonline.org/ periods/stuarts/day-21-november-1606-proposed-union-between-england-and-scotland. 209 Curran, "Erotic Policy," 57-58.

210 Levack, Formation, 181; Goodare, Government, 106.

211 Lodge, 1791 ed., vol. 3, 350-353; Cokayne, ed., vol. 4, 340.
} 
Fermor, ${ }^{212}$ the 1609 Haddington-Ratcliffe ${ }^{213}$ and d'Aubigny-Clifton, ${ }^{214}$ and the 1612 Howard-Home alliances. ${ }^{215}$

Briticisation on a single, marriage-by-marriage basis resulted from James's own instigation. It was accomplished via the royal prerogative and became his legacy. ${ }^{216}$ James realised these marriages through personal organisation and support and through patron-client relationships fostered in his "politically stable and monarchically loyal court."217 Anglo-Scottish marriages were a mirror of James's royal prerogative, his power and ability to compel his court to accept and comply with his vision of Britain. ${ }^{218}$ That said, Brown and Levack have maintained that Anglo-Scottish intermarriage had little effect on the court cultures of either country and did little to bring them together. ${ }^{219}$ But, as Galloway has noted, "Perfect union was a long-term goal, to be achieved gradually." 220 Indeed, Brown has observed that "For nobles, marriage was a long-term ambition."221 Campion had echoed the same idea in his The Lord Hay's Masque: "The hope is that the new bride will bring forth an Anglo-Scottish heir; the one he begets later will be British: thus a new posterity, born from the two kingdoms." 222 And, James himself remarked that the union was "perfect in my title and descent, though it be not an accomplished and full Union; for that time must ripen and work... I would not have you think on that to be done To-day, that is to be done To-morrow."223 Seen in this light, it is conceivable that James did not necessarily intend for the Anglo-Scottish marriages he supported to make an immediate or direct impact during his reign. He, instead, may have had a longer-term perception of Briticisation, akin to Elizabeth's practice of using marriages to bring the Catholic nobility steadily to

212 The Register of the Great Seal of Scotland, ed. John Maitland Thomson, vol. 7 (Edinburgh: H. M. General Register House, 1886-1894), 49; Paul, ed., vol. 3, 231; Cokayne, ed., vol. 3, 541.

213 Lodge, 1838 ed., vol. 3, 208; Rimbault, ed., 161; TNA, SP 14/26/79; W. D. Macray, ed., Beaumont Papers (London: Nichols and Sons, 1884), 17-18; Juhala, 313; Cokayne, ed., vol. 6, 534.

214 HMC, Report on the Laing Manuscripts, vol. 1 (London: H. M. Stationery Office, 1914), 106-107; Lodge, 1838 ed., vol. 3, 208; Elizabeth Cust, Some Account of the Stuarts of Aubigny, in France: 1422-1672 (London: Chiswick Press, 1891), 98; Stone, Crisis, 102; Cokayne, ed., vol. 7, 612; ODNB, s.v. "Stuart, Esmé, third duke of Lennox."

215 Chamberlain, vol. 1, 385; RPC, 1610-1613, 128n; Richard Griffin, Baron Braybrooke, The History of Audley End (London: Samuel Bentley, 1836), 42-43; Cokayne, ed., vol. 12/1, 467.

216 Cuddy, "Anglo-Scottish Union," 107-108.

217 Curran, Marriage, 46.

218 Loughlin, 841.

219 Levack, Formation, 186-187; Brown, “Scottish Aristocracy," 569-575; idem, Kingdom or Province?, 46-47.

220 Galloway, 119.

221 Brown, Noble Society, 119.

222 Campion, 210.

223 William Cobbett, Cobbett's Parliamentary History of England, vol. 1 (London: R. Bagshaw, 1806), 1116-1117. 
Protestantism. And, though it was not fully realised within his reign, Briticisation remained his enduring legacy.

\section{Buckingham-Manners, 1620}

The hope of a statutory union of England and Scotland now long forgotten, the latter half of James's reign in England focussed instead on royal finances, avoidance of Parliament and war, marriage negotiations of his heir Charles, and the king's last favourite, George Villiers, marquess of Buckingham. ${ }^{224}$ As royal favourite, a gentleman of the bedchamber, and lord admiral, Buckingham was the most powerful nobleman in the kingdom: "the king's favour render[s] him the chief authority in everything, and the entire court obeys his will." 225 As "the disposer of ...[James's] goodwill," the enhancement of one's court standing and career progression depended on Buckingham, "All requests pass through him and without his favour it is most difficult to obtain anything or to reach the king's ear."226 In fact, by 1623 Buckingham, like the earl of Somerset before him, acted as "both chief minister and principal patronage broker." 227 It was possible to view him almost as James himself, authority and bounty in one. As a result, Buckingham's close relationship to the king incited intense jealousy due the preferential treatment and lucrative benefits he received. ${ }^{228}$ It is also possible, according to Michael Young, that the marquess was the king's lover. ${ }^{229}$

Regardless of the nature of the relationship, the king had urged all of his previous favourites to marry and Buckingham was no different. ${ }^{230}$ So, acting in loco parentis, James also encouraged the marquess's bid for the hand of wealthy Catholic heiress Lady Katherine Manners, daughter of Francis, sixth earl of Rutland. ${ }^{231}$ A marital alliance would have joined the Manners family's wealth and established pedigree with the newly-arrived Buckingham and his undoubted influence with the king. The marriage would also have been inter-denominational,

\footnotetext{
${ }^{224}$ After the fall of Robert Carr, earl of Somerset, in 1616, Buckingham became James's favourite.

225 CSPV, 1617-1619, 468; Lockyer, Britain, 65; Russell, James, 179.

226 Hill and Lockyer, 21; CSPV, 1617-1619, 468; Lockyer, Buckingham, 41.

227 Hill and Lockyer, 30.

228 Buckingham's power and influence were seemingly unassailable, making him deeply despised. See CSPV, 1617-1619,

94, 335; Hille, 101-102; R. Malcolm Smuts, ed., The Stuart Court and Europe (Cambridge: Cambridge University Press, 1996), 140.

229 Young, 544-545

230 Schreiber, 9.

231 TNA, SP 14/109/183; ibid, SP 14/105/10; Godfrey Goodman, The Court of King James I, ed. John S. Brewer, vol. 2 (London: Richard Bentley, 1839), 192.
} 
but the king bestowed his consent with a caveat. As head of the Protestant churches of both Scotland and England, James would not permit his favourite's marriage to a Catholic. 232 This was unsurprising as stipulations of conversion to Protestantism had already been made for the 1588 Huntly-Stewart and 1592 MarStewart marriages. In Basilikon Doron James had advised that "disagreement in Religion bringeth ever with it, disagreement in manners; will breed and foster a dissention among your subjects, taking their example from your family." 233 Consequently, in a move which demonstrated his ascendancy and control over his favourite, James instructed one of his chaplains, John Williams, to persuade Lady Katherine to give up the Roman faith, although she had previously refused to "conform in point of religion." 234

In the meantime, after more than a year of fruitless discussions, Buckingham's mother decided to press the matter of marriage and the king himself may have been involved in her scheme. ${ }^{235}$ She invited Lady Katherine to dine, concealed the fact that her son would be present, and kept her overnight. Not returning home, spending the night under the same roof as her suitor, placed Lady Katherine in an unseemly position. She was denied entry into her father's house the next day. ${ }^{236}$ After this event, Rutland wrote to Buckingham confirming that the marquess would now immediately take his daughter as his wife: "that I may by some course be assured she is yours." Buckingham, not to be coerced, claimed that he was now resolved to "leave off the pursuit of that alliance any more."237 The feeling at court, however, was that "the match must go on... or else he [Buckingham] should do her great wrong."238 To save his daughter's position and reputation Rutland finally agreed to the terms of the marriage contract.239 And,

\footnotetext{
232 Lockyer, Buckingham, 59.

$233 \mathrm{JPW}$, 41. Buckingham, like James, had more liberal views on religion and probably would have married Manners without her converting to Protestantism. See Lockyer, Buckingham, 59.

234 TNA, SP 14/110/30; ibid, SP 14/113/45. Chamberlain described Lady Katherine as an "obstinate papist."

235 Buckingham's "exorbitant demands" for the marriage settlement included $£ 20,000$ "ready money," lands valued at $£ 4,000$ per year, and an additional $£ 8,000$ of land should Lady Katherine become her father's sole heir. See TNA, SP 14/113/45. See also Goodman, vol. 2, 191; TNA, SP 14/113/78.

236 TNA, SP 14/113/65; Gardiner, vol. 3, 56.

237 Goodman, vol. 2, 190, 192; Gardiner, vol. 3, 357.

238 TNA, SP 14/113/160.

239 Chamberlain, vol. 2, 306.
} 
Chaplain Williams was ultimately successful. Lady Katherine did convert to Protestantism and the couple wed on 16 May 1620 in the presence of the king. ${ }^{240}$

The Buckingham-Manners wedding was expected to be a highly celebrated court event as the marriages of James's previous favourites had been. Instead, it was a surprisingly quiet affair observed in private. ${ }^{241}$ As such, the king was prevented from bestowing open, public attention upon the couple and their respective families who were brought together through the marital alliance. This may have been because the couple did not want to highlight the embarrassing event which had forced their alliance. The king probably believed that the lateral connection between the Villiers and Manners families was non-threatening to his monarchy, particularly with Buckingham's unquestionable loyalty. It is also likely that the strangely closeted wedding connected to the Commons's ongoing investigation into controversial but highly lucrative monopolies which were sanctioned by the crown, protected by the royal prerogative, and dispensed by Buckingham, some believed corruptly. Grand, expensive revels to mark the occasion of the Buckingham-Manners marriage almost certainly would have raised the ire of the king's and marquess's detractors, especially those in Parliament which was set to convene in January $1621 .^{242}$ Additionally, some at court alleged that Buckingham's wedding was directly linked to James's marriage discussions regarding Charles and the Spanish Infanta Maria Anna: "if the match with Spain proceed... [the Buckingham-Manners marriage] had been a principal motive to draw it on." In March 1620, just prior to the marriage, Spanish ambassador Don Diego Sarmiento de Acuña, Count of Gondomar, arrived in London. Gondomar received much regal favour and attention as James desired to continue discussions for a Spanish match. 243 In this seemingly pro-Catholic, pro-Spanish backdrop, James still demanded Lady Katherine's conversion.

The king's own commitment to Protestantism had, in recent years, appeared dubious and likely figured in his mandate to Lady Katherine. That Queen Anne had allegedly converted to Catholicism and harboured Catholics within her

\footnotetext{
240 Hacket, 10; Gardiner, vol. 3, 357; Lockyer, Buckingham, 59-60; Hille, 132; A. T. Thomson, The Life and Times of George Villiers Duke of Buckingham, vol. 1 (London: Hurst and Blackett, 1860), 235, 248.

${ }^{241}$ CSPV, 1619-1621, 169; Chamberlain, vol. 2, 306; Lockyer, Buckingham, 60.

242 Smith, Stuart Parliaments, 109; Hille, 132-133.

243 TNA, SP 14/113/45; Gardiner, vol. 3, 345; CSPV, 1619-1621, xl-xli.
} 
household had been marks against the king. ${ }^{244}$ The Five Articles of Perth, passed in 1618 by Scotland's General Assembly, had enforced kneeling during communion, an action deemed Catholic. ${ }^{245}$ The king's search for a Catholic bride for Charles further highlighted the matter. Each of these factors cast doubt on James's dedication to the reformed religion and the Churches of England and Scotland. If James had allowed an interdenominational Buckingham-Manners marriage it would have signalled a willingness to permit greater freedom for all English Catholics-King Philip III of Spain had already stipulated this in the Charles-Maria Anna negotiations. ${ }^{246}$ Such a move would have alienated many in the government and church as it suggested pro-Catholic domestic and foreign policies. ${ }^{247}$

Russell has also pointed out that a Catholic marriage for Charles would have broached "the issue of law versus prerogative."248 The same could be said for Buckingham's marriage due to his position as the king's favourite. Since the practice of Catholicism in England and Scotland was illegal, to what extent could James use the royal prerogative to bypass the law for his family members and favourites? Similarly, the dispute over law versus prerogative connected to monopolies, in particular. Buckingham, as the royal favourite, was chief recipient and distributer of crown privileges, monopolies among them. This made him a reviled figure at court, especially when numerous monopolies were held by his brothers, thus raising the question of corruption. ${ }^{249}$ The legality of monopolies was to be a central topic of discussion in the 1621 Parliament. As a result, it would be a direct assault on Buckingham as the broker of crown benefits and an indirect attack on the king. 250 With his devotion to Protestantism suspect and the controversy surrounding Buckingham and monopolies, James would have wished to prevent debate on the royal prerogative. This desire to avoid discussions may have been the main justification for a quiet commemoration of the BuckinghamManners nuptials. Moreover, the private and forced intra-denominational Buckingham-Manners marriage conveyed multiple messages: first, of James's

\footnotetext{
244 ODNB, s.v. "Anne [Anna, Anne of Denmark]."

245 MacDonald, 158.

246 Croft, King James, 118.

247 MacDonald, 165; Lockyer, Buckingham, 18-19.

248 Russell, James, 180-181.

249 CSPV, 1617-1619, 94, 335; Smith, Stuart Parliaments, 109; Hille, 101-102; Lockyer, Britain, 288-289; R. Malcolm Smuts, ed., The Stuart Court and Europe (Cambridge: Cambridge University Press, 1996), 140.

250 Hille, 133
} 
understanding of the controversy caused by monarchical benefits; second, of his ostensible commitment to Protestantism; third, of his upholding of the law which prohibited the practice of Catholicism; fourth, his encouragement of the conversion and compliance of leading noble Catholics; and, fifth, that despite Buckingham's indomitable power at court, James could still command his favourite-his hierarchical supremacy was intact.

For James, the Buckingham-Manners marriage was a public relations crisis, domestic and foreign. Nonetheless, the patron-client relationship established at the wedding was successful as was the king's authority and domination. Because James himself raised Buckingham to the status of favourite, the hierarchical impact of the Buckingham-Manners marriage, the lateral connection established with the joining of the Villiers and Manners families, was minimal. The couple remained loyal and obedient subjects and continued to receive royal patronage even after James's death in 1625 and the ascension of Charles I. ${ }^{251}$ It did transpire, however, that Lady Katherine's conversion to Protestantism was perfunctory. She returned to the Catholic faith after the deaths of James and Buckingham; death effectively ending all obligations of the patron-client relationship. ${ }^{252}$

\section{Conclusion}

Cited at the beginning of this chapter, Kettering's observation that no official commemoration accompanied the initiation of patronage in sixteenthcentury France ${ }^{253}$ does not apply to early modern England and Scotland. The above case studies have shown that Elizabeth and James did take advantage of the opportunities to celebrate personally and very publicly noble marital alliances. Both monarchs consistently advocated marriages by granting the gift of their attendance at ceremonies or wedding festivities which implied the initiation of new patronage ties which acknowledged the alliance created between familieslateral bonds in a hierarchy. As a result, Stone's perception of Elizabeth's negative interference has been amended; she was often supportive of noble alliances. In

251 TNA, SP 14/145/17; HMC, Eleventh Report, Appendix, Part 1 (London: H. M. Stationery Office, 1887), 3, 6. Buckingham was elevated to a dukedom in 1623.

252 Lockyer, Britain, 272; ODNB, s.v. "MacDonnell [née Manners; other married name Villiers], Katherine, duchess of Buckingham and marchioness of Antrim."

${ }^{253}$ Kettering, "Gift-giving," 146. 
addition, marriage sponsorship allowed Elizabeth and James to strengthen already-existing associations, as Barrow's research has conveyed. ${ }^{254}$

Elizabeth almost exclusively used the royal person as a means of showing support most likely because it was effective and inexpensive. Not naturally frugal, James's belief that he was the ultimate provider to his people prevented him from harnessing spending. ${ }^{255}$ Along with payments towards marriage jointures and other gifts, he offered another level of support to weddings to which there was no corresponding gesture in the Elizabethan period. As seen in the Huntly-Stewart, Mar-Stewart, Herbert-Vere, Essex-Howard, and Hay-Denny marriages, James personally gave away the bride during the wedding ceremony. This act was as an additional overt endorsement as well as direct physical involvement in the joining of two noble subjects. Giving away the bride allowed James to stake a corporeal and symbolic claim within the noble alliance. The newly-formed patron-client bonds which the royal presence at a marriage conferred reinforced the hierarchy of the period and highlighted the loyalty, reciprocity, and commitment the noble couples owed to their monarch. By personally and publicly recognising and patronising marriages both monarchs firmly emphasised couples' as well as their families' loyalties to the crown rather than between each other. Elizabeth's and James's promotion of marriages, in turn, helped to realise crown policies and legacies, written and unwritten.

Farrell has pointed out that uneven power could affect levels of trust. Notably, despite their hierarchical supremacy, Elizabeth and James did maintain sufficient levels of allegiance and trust with many of their nobility. This achievement exposes the importance of exclusive monarchical privileges - titles, offices, lands-for the establishment of patronage which led to successful noble relations and greater stability. Indeed, the above case studies have demonstrated that Elizabeth's and James's supportive approach to marriages operated alongside prerogatives. Following the crises of the late 1560s and early 1570s, the Elizabethan government's undeclared efforts to weaken Catholic noble influence through support of interdenominational marriages reveal the silent manoeuvrings of the royal prerogative. These quiet endeavours steadily converted England's

254 Barrow, 69.

255 Tanner, 355; Smith, Stuart Parliaments, 108. 
future leaders to Protestantism which bolstered the Church of England. Likewise, James's unofficial Briticisation policy sought to commingle the English and Scottish aristocracies to produce future "British" subjects. The Anglo-Scottish noble marriages which took place after 1607 exhibited James's use of the royal prerogative to bypass Parliament and encourage his courtiers to accept and advance his idea of Britain. The king's central role in the Essex-Howard annulment was part of this endeavour. The Hay-Denny case study, in particular, has supported Galloway's research that James's goals of union and Briticisation were long-term, rather than immediate. This chapter has shown that crown privileges played an integral part in the management of the nobility and their alliances-their persistent use has, consequently, revealed Elizabeth's and James's absolutist tendencies.

Nevertheless, open, public backing of a marriage was an effective means of establishing successful, long-term patron-client associations with the nobility. For both Elizabeth and James the vast majority of the patron-client relationships established through supportive involvement in marriages remained intact until either the monarch's death or the death of the bride or groom. Moreover, most of the religion-linked marriages in which Elizabeth participated enjoyed long-term patron-client relationships. Similarly, James was successful in that all of the AngloScottish marriages in which he took part resulted in long-standing patron-client associations. From these standpoints, the championing of marriages was an indispensable element of the monarchical office: it repeatedly produced enduring patronage ties which aided in stronger monarch-noble bonds and upheld royal supremacy. 


\section{Chapter 4}

\section{"Silent indecision"?: monarchical non-participation in noble marriages ${ }^{1}$}

A double wedding ceremony which joined the influential noble families of Herbert and Talbot took place on 17 February 1563 at Baynard's Castle, the London residence of William Herbert, second earl of Pembroke. Pembroke's heir, Henry, married Katherine, daughter of George Talbot, sixth earl of Shrewsbury. Simultaneously, Shrewsbury's heir, Francis, married Pembroke's daughter Ann. Continuing for four days, the wedding festivities included "a great dinner as [has] been seen... and every night great mummers and masks." 2 This multi-day celebration occurred among nobility closely allied to Elizabeth, but, interestingly, the historical record is silent regarding the queen's response. Both earls were prominent supporters of the Elizabethan regime and had played significant roles in her coronation: "Beside her Majesty there stood those two Earls... Shrewsbury and Pembroke, with the sceptre and orb in their hands." 3 In addition, Pembroke had hosted Elizabeth at Baynard's Castle twice already, in 1559 and 1562, but if she was involved in or present at the double wedding ceremony, it was not recorded. ${ }^{4}$

Anthropologist Michel-Rolph Trouillot has written that history is "made of silences." His research has explained the production of history as stages of fact "creation... assembly... retrieval" and reflection, noting that lack of information or "silence" can infiltrate each stage. Trouillot has also suggested that power differentials affect the management of facts and what histories are created. Some details or sources are privileged by individuals or groups; others are minimised or disregarded, producing a "silence" around certain historical persons or events. ${ }^{5}$ Silence, power, and trust are key components in this chapter which analyses a

\footnotetext{
1 Alford, 159.

2 Henry Machyn, The Diary of Henry Machyn, Citizen and Merchant-Taylor of London, from A.D. 1550 to A.D. 1563, ed. John Gough Nichols (1848; reprint, New York and London: AMS Press, 1968), 300, 392; Thomas Wright, ed., Queen Elizabeth and Her Times, vol. 1 (London: Henry Colburn, Publisher, 1838), 130.

${ }^{3}$ CSPV, 1558-1580, 18.

${ }^{4}$ Cole, 181.

5 Michel-Rolph Trouillot, Silencing the Past: Power and the Production of History (Boston: Beacon Press, 1995), 152, 2628, xxiii.
} 
mysterious form of noble-marriage management-non-participation. To clarify, I have located no proof which suggests that the monarch attended celebrations or showed any form of support or acknowledgement prior to the marriage. Nor did they voice or indicate any immediate opposition. Instead, they appear to have met these unions with silence. Especially intriguing is that a member of the couple or his or her parents were near relations of or well-known to the monarch, served in the royal household, or worked in a high-level administrative capacity. All of these relationships would have brought regular and close contact. Also of prominence is that the weddings discussed herein were not clandestine-unions contracted secretly are examined in chapter five. Nothing that I have located suggests that these marriages were secretly contracted or purposefully celebrated without the monarch's knowledge. Since noble marriages were of too great a significance to contract secretly, history's silence on the monarch's response to those described here is potent.

This chapter investigates why Elizabeth and James appear to have remained silent and did not engage in the marital alliances of certain powerful, high-ranking aristocrats. The lateral connections of marriage established between influential families were potentially damaging to the hierarchy; reticence was understandable. It argues that monarchical silence often surrounded couples whose loyalty to the crown was in doubt or who had in other ways earned reproach. Crucially, this chapter contends that monarchical non-participation and silence were, in fact, important features of the royal prerogative. The case studies below centre on Elizabeth; only one is provided for James. The examples attempt to explain monarchical silence by describing what details are known of the weddings and the monarch-noble relationships. Also considered within the analyses are contemporary events that might have impacted participation and whether Elizabeth or James ever chose to acknowledge the union. By taking into account these aspects along with crown entitlements like the royal prerogative and acting in loco parentis, it becomes possible to provide alternative explanations for monarchical non-engagement or passivity in what were important unions.

A lack of evidence of both monarchs' involvement raises the question of whether royal non-participation should be construed positively or negatively. Royal absence or unresponsiveness may be viewed in several ways. The monarch 
may have possessed no right to intervene, deemed the union non-threatening, or harboured an uncertainty over or distrust of the alliance. Regarding the HerbertTalbot double wedding, Elizabeth had no plural prerogative of wards' marriages nor was she operating in loco parentis. Either privilege would have given her right of approval or a reason to interfere. It is likely that Elizabeth did not consider the Herbert-Talbot weddings dangerous to the crown, thus, her lack of engagement did not signify disapproval. Perhaps because Shrewsbury and Talbot were already viewed as loyal and trusted servants, further patronage of their new familial alliance was unnecessary. Still, chapters two and three have shown that patronage mattered because it was the best way for the monarch to establish enduring connections with the nobility. And, due to their inequality, patron-client relationships depended upon trust.

Farrell's observations on power imbalances affecting levels of trust, already discussed in chapters one and three, are applicable once again in this chapter. ${ }^{6}$ Similarly, in examining trust and distrust, political science scholar Deborah Larson has observed that "Like trust, distrust is grounded partly in learning and experience" and, at the same time, "Distrust is often prudent because we cannot know fully the motives or intentions of many people we encounter."7 Moreover, Kettering has remarked that though "Clientage... used the chivalric rhetoric of loyalty... whatever the reality of the situation... A patron did not tolerate disloyalty from his clients."8 Patron-client relationships, like the prevailing hierarchy of the period, were asymmetrical. The horizontal connections marriages created between kin groups potentially drew family allegiances and attentions inwards rather than upwards, particularly if crown recognition of the marital alliance was absent. The weddings discussed below reflect the connection between the monarchs' level of perceived trust and their level of involvement and assess their political wisdom at distancing themselves from these alliances. All but one marriage touches on problematic interdenominational unions which provoked questions of allegiance and adherence to crown-backed religious policies. While chapter three has shown that interdenominational marriages sometimes received

\footnotetext{
6 Farrell, 86.

7 Deborah Welch Larson, "Distrust: Prudent, If Not Always Wise," in Distrust, ed. Russell Hardin (New York: Russell Sage Foundation, 2004), 43, 38.

${ }^{8}$ Kettering, “Gift-giving," 136, 137.
} 
royal approbation, this chapter will illustrate that approval for blended CatholicProtestant noble weddings was not always forthcoming. In those cases where the loyalties of the couple were ambiguous, the scarcity of details of monarchical involvement may be explained in a novel way, namely, in terms of the royal prerogative.

As mentioned in chapters two and three, silence formed a part of the royal prerogative. ${ }^{9}$ When viewed in this light, the noble marriages which Elizabeth and James seemingly handled with silence or non-participation may be newly understood within this context. A lack of evidence can be interpreted as a monarchical silence or an application of the royal prerogative towards questionable marriages. Here, Trouillot's research is relevant as the silence of the historical record may correlate to the silence of the royal prerogative. What seems apparent is that Elizabeth and James voicelessly handled the imminent marriages of upper-level noble couples whose loyalty to the crown was in doubt, especially if one member had a connection to the throne. The silence also seems to have been employed as an implicit reproach against those who overtly resisted crown policies, like state-enforced Protestantism, when open monarchical censure would have been unwise. ${ }^{10}$ Ultimately, each of the noblemen described below lost the monarch's favour. And, it is possible that the hierarchical supremacy, power, and authority of the monarchical office enabled Elizabeth and James to create and control histories which, based on Trouillot's theory, may explain why few explicit details remain of these undesirable and potentially threatening alliances.

Furthermore, Kettering has specifically mentioned seventeenth-century French patronage brokers who "sought to intimidate and silence political opposition to the policies of their patron and to the crown." In a similar manner, it seems highly likely that Elizabeth and James would have used the royal prerogative silence in an attempt to control or intimidate clients. For example, Elizabeth initially met the 1594 birth of James's first born son and heir, Prince Henry, with a "stony silence," annoyed with the Scottish king's lack of disciplinary

\footnotetext{
${ }^{9}$ Kantorowicz, "Mysteries of State," 69. As stated in chapter two, James conceived of mysteries of state and the royal prerogative as one in the same.

10 Kettering, Patrons, 119, 127.
} 
action against the Catholic earl of Huntly. ${ }^{11}$ Mute reaction may also have signalled a royal prerogative-induced, wait-and-see approach which anticipated the eventual outcome of the union, whether the couple would reveal themselves as pro-monarch or engage in subversive anti-regime activities as in the WestmorlandHoward or Argyll-Cornwallis marriages described below.

\section{Database}

The monarch's prominent lack of involvement has been recorded for eleven marriages in the database. Noted in Table 2.2, non-participation occurred more frequently in Elizabeth's reign, with only three instances designated in James's. This phenomenon was exclusive to upper-level nobility. In every case the monarch had a close tie with at least one member of the marrying couple, either a bond of kinship or faithful service, so his or her absence of involvement or patronage seems conspicuous. As mentioned, four of the five marriages illustrated herein were interdenominational. As the cases that follow illustrate, interdenominational marriages sometimes occasioned strangely hushed monarchical responses, particularly when the participants were leading magnates or had ties to the throne. Also noteworthy is that three of the marriages described in this chapter were subsequent marriages for either one or both of the betrothed. Second marriages may have generally been celebrated with less ostentation than first marriages but there were exceptions, such as the 1565 Warwick-Russell, 1592 Mar-Stewart, and 1613 Somerset-Howard weddings. ${ }^{12}$

Elizabeth employed the strategy of non-participation from 1558 until the early 1580s. She chose not to engage in these marriages despite having family or royal service connections to at least one member of the couple. Furthermore, several of these marriages involved Catholic or Catholic-sympathising nobility with ties to northern England. Mary, queen of Scots's flight into England, the Northern Rebellion, the issuance of the papal bull of excommunication, and the Ridolfi plot were events which altered the queen's response to the marital unions of northern

\footnotetext{
11 Guy, 241. After six-months of evasion, however, Elizabeth finally agreed to send a representative to the baptism festivities which James had postponed, awaiting her emissary. Originally, that representative was to be the earl of Cumberland, formerly a judge at Mary, queen of Scots's trial, but another more tactful replacement was found. See Roger A. Mason, "1603: Multiple Monarchy and Scottish Identity," History 105 (2020): 408; Kinney, ed., 179. Robert Radcliffe, fifth earl of Sussex, attended Prince Henry's baptism in Cumberland's place.

12 Cressy, Birth, 293.
} 
Catholic aristocrats as mentioned in chapter three. On the other hand, James rarely used a non-participatory or passive approach to noble marriages and I have linked only three weddings to lack of involvement where it might otherwise have been reasonably anticipated. One of the marriages, the Argyll-Cornwallis, is described below. A second involved the king's cousin Ludovick Stuart, second duke of Lennox and the premier peer of Scotland, who quietly wed in 1598 Jean Campbell, daughter of Sir Mathew Campbell. ${ }^{13}$ A third marriage took place in 1622 between Thomas Hamilton, son and heir of Thomas, earl of Melrose and first earl of Haddington, and Katherine Erskine, daughter of John, second earl of Mar. The king may not have viewed the union with "much favour" due to the earls' power and influence. ${ }^{14}$ The following case studies show that issues of trust and loyalty, along with concern over the adherence to Catholicism of individuals involved in the unions, figured largely in both monarchs' lack of involvement.

\section{Elizabethan case studies}

\section{Norfolk-Audley, 1558}

From 1558 to the early 1570s Thomas Howard, fourth duke of Norfolk, Queen Elizabeth's cousin and England's premier peer, married twice and treasonously attempted a third marriage which led to his attaintment for treason and execution in 1572.15 During this time he also advantageously matched his children from his first and second wives to those of his third deceased wife in a process which epitomised wardship and wards' marriages. Elizabeth did not appear to participate in any of these marriages. This is striking considering the kinship ties between them and the important role the duke played in Elizabethan court and government and is therefore worthy of discussion.

Norfolk's second marriage was to the widowed Lady Margaret Audley, a "devout Protestant," daughter and sole heir of Thomas, baron Audley of Walden. ${ }^{16}$ Their first spouses having both died in August 1557, Norfolk and Lady Margaret's

\footnotetext{
13 RPC, 1592-1599, xcii; Brown, Noble Society, 135; Paul, ed., vol. 5, 497; ODNB, s.v. "Stuart [Stewart], Ludovick, second duke of Lennox and duke of Richmond." See also RPC, 1604-1607, 440, 551.

14 Paul, ed., vol. 4, 316; ODNB, s.v. "Hamilton, Thomas, second earl of Haddington;" ibid, s.v. "Erskine, John, eighteenth or second earl of Mar."

15 Griffin, 30.

16 ODNB, s.v. "Howard, Thomas, fourth duke of Norfolk."
} 
marriage was already planned by April 1558. ${ }^{17}$ With their courtship having begun during the Catholic Mary I's reign, a papal dispensation was required before their marriage could take place because Norfolk and Lady Margaret were blood relations. Lady Margaret was also a first cousin of Norfolk's first wife. On both counts, the marriage fell within the realm of consanguinity which was prohibited by canon law. ${ }^{18}$ In addition, because Lady Margaret's first husband was deceased her remarriage would have required either the queen's approval or a licence from the Court of Wards and Liveries as a widow's marriage. ${ }^{19}$

At some point in late 1557 or early 1558 Norfolk sent his lawyer to Italy to apply for a papal dispensation for his marriage to Lady Margaret. ${ }^{20}$ From April through July 1558, Mary received monthly updates on its status from her ambassador to the Holy See, Sir Edward Carne, who wrote, "As yet the Duke of Norfolk's dispensation for his marriage is not had."21 That Mary was being updated on the progress of the request corroborates that she was aware of Norfolk and Lady Margaret's intention to marry. Carne made no further mention of the dispensation after July 1558 and the Venetian ambassador later confirmed that it was never obtained. ${ }^{22}$ Mary died on 17 November 1558, and the new Protestant Queen Elizabeth I ascended the throne.

Elizabeth arrived in London on 23 November 1558, "attended with a thousand or more, of Lords, Knights, Gentlemen, Ladies and Gentlewomen," Norfolk among them. ${ }^{23}$ Perhaps already aware of Elizabeth's commitment to Protestantism, Norfolk and Lady Margaret abandoned their papal dispensation quest and were "quietly" married sometime later in the month, on 28 or 29 November $1558 .{ }^{24}$ Because much of the nobility was in London around this time welcoming the new queen, it is plausible to assume that the Norfolk-Audley

\footnotetext{
${ }^{17}$ Norfolk married Lady Mary Fitzalan around 1554 and she died in August 1557 following childbirth. Lord Henry Dudley married Lady Margaret Audley in 1554 and was killed in the battle of St. Quentin in August 1557. See Machyn, 149-150; John Strype, Ecclesiastical Memorials, vol. 5 (London: Printed for Samuel Bagster, 1816), 149; Griffin, 26; CSPF, 1553-1558, 370; ODNB, s.v. "Howard [née Fitzalan], Mary, duchess of Norfolk;" ibid, s.v. "Howard, Thomas, fourth duke of Norfolk."

18 Neville Williams, Thomas Howard, Fourth Duke of Norfolk (London: Barrie and Rockliff, 1964), 34 [hereafter, Williams, Norfolk]; ODNB, s.v. "Howard, Thomas, fourth duke of Norfolk."

${ }^{19}$ Harris, English Aristocratic Women, 161; Hurstfield, Queen's Wards, 148.

20 CSPV, 1557-1558, 1569; Williams, Norfolk, 34-35.

21 TNA, SP 69/13/19; CSPF, 1553-1558, 370, 374, 389. See also G. R. Elton, The Parliament of England, 1559-1581

(Cambridge: Cambridge University Press, 1986), 312-313.

22 CSPV, 1557-1558, 1569.

23 Machyn, 178; Nichols, Elizabeth, vol. 1, 29, 31-32.

24 Williams, Norfolk, 35.
} 
marriage took place there though there are no details. No evidence remains of any role Elizabeth may have played at that time. It is probable that her nonparticipation can be attributed to her recent ascension to the throne and the activity surrounding the establishment of her reign. Though nominally she had a plural prerogative right of approval over this widow's marriage, a licence to remarry was most likely purchased. Moreover, as a royal ward, Norfolk had requested Queen Mary's approval of his first marriage in 1553, and, though no longer a ward in 1558, it would have been almost certain that as a kinsman and the kingdom's leading noble he would have sought the same endorsement from his new queen out of respect. ${ }^{25}$

The most evident monarchical act which related to the Norfolk-Audley marriage took place shortly after the wedding when the new duchess of Norfolk joined Elizabeth's privy chamber either in late 1558 or early 1559.26 Margaret of Norfolk also received the high honour of carrying "the Queen's long train" on coronation day, 15 January 1559.27 The duchess's entrance into the queen's household signified approval and support of the Norfolk-Audley marital alliance and alluded to Elizabeth's initiation of a monarch-noble patron-client relationship with the couple. As the premier peer, it was critical that Elizabeth had the influential Norfolk's backing from the start of her reign. Showing support through patronage for the duke's alliance with Lady Margaret was one important way to achieve that. With the queen's recognition confirmed, the Norfolks commemorated their union with twin portraits by Hans Eworth which were completed in 1562. The paired images display each sitter, "luxuriously dressed," in clothing heavily detailed with silver and gold threads-materials which were "restricted by law to those of the rank of a duke."28 The panels heralded this highest-ranking noble couple's unmistakable social position and wealth.

Even with obvious post-wedding monarchical approval, due to England's continuation as a Catholic kingdom until the close of Elizabeth's first Parliament in May 1559, the legitimacy of the Norfolk-Audley marriage was questionable under canon law. As a result, the "Bill for the Ratification of the Marriage between the

25 ODNB, s.v. "Howard, Thomas, fourth duke of Norfolk."

${ }^{26}$ Nichols, Elizabeth, vol. 1, 37; Merton, 258; Kinney, ed., 26.

27 CSPV, 1558-1580, 16.

28 Cooper and Eade, eds., 80-81, 82. 
Duke of Norfolk, and the Lady Margaret now his Wife, and for the assurance of certain Lands for her Jointure" was approved by both houses of Parliament on 6 March 1559, thus confirming its secular validity. ${ }^{29}$ According to Geoffrey Elton, it was common practice among the nobility to ensure their marriages were legally binding by using parliamentary statutes to formalise family arrangements like marriage jointures. ${ }^{30}$ Norfolk, having guaranteed the secular validity of this marriage, continued his work in Parliament. He assumed an active part in the Elizabethan regime at its earliest stage and was committed to his role as revealed through regular attendance at Parliament, "48 of the 54 business days," and his appointment "to five bill committees." 31 Of importance, too, was that Norfolk acted as a Protestant voice among the largely conservative and Catholic spiritual and temporal members of the House of Lords. ${ }^{32}$

Despite the lack of evidence of any pre-wedding monarchical sanction or involvement, extant facts imply that the Elizabeth-Norfolk-Audley patron-client relationship was successful with both parties serving each other and receiving benefits. Elizabeth retained Margaret of Norfolk in her household while she showered the duke with multiple honours and high offices including lieutenantgeneral of the north, Order of the Garter, lord-lieutenant of Norfolk, privy councillor, and earl marshal. ${ }^{33}$ Monarchical patronage and noble clientage continued until the Elizabeth-Norfolk-Audley relationship was terminated with the death of the duchess in $1564 .{ }^{34}$ The queen's early and obvious patronage of the premier couple, the key roles the duke and duchess played in the public eye in ceremonial and government events and in the privacy of the royal household, made manifest, notwithstanding unequivocal proof, that this noble marriage received critical monarchical endorsement and favour.

\footnotetext{
${ }^{29}$ D'Ewes, 22. See also CJ, vol. 1, 57.

30 Elton, Parliament, 312.

31 ODNB, s.v. "Howard, Thomas, fourth duke of Norfolk;" D’Ewes, 21-26.

32 Hartley, 81; J. E. Neale, Elizabeth I and her Parliaments, vol. 1 (London: Jonathan Cape, 1953), 40-41; Rosemary Sgroi,

"1559 Parliament," The History of Parliament Online, accessed 5 December 2019, https://www.historyofparliamentonline.org/volume/1558-1603/parliament/1559-0.

33 TNA, SP 59/3/1; Kinney, ed., 3, 60, 116, 183, 243; Hayward, 48.

34 Strype, Annals, vol. 1/2, 44-45.
} 


\section{Westmorland-Howard, 1564}

While Norfolk served in Parliament his older sister, Lady Jane Howard, personally served Elizabeth. In late 1558 or early 1559, Lady Jane entered royal service as a maid of honour to her cousin the queen. ${ }^{35}$ Kinship and close attendance created a connection between the two women, but that connection possibly went deeper. Lady Jane and the queen were intellectual equals, both having been highly educated in the humanist tradition, and they each had had a parent executed for treason. ${ }^{36}$ It is plausible that these links between them were what protected Lady Jane in years to come. Lady Jane remained in Elizabeth's household until her marriage in 1563 or 1564 when she wed Charles Neville, styled lord Neville, later sixth earl of Westmorland. ${ }^{37}$ Lady Jane was related to the Neville family through her mother and father, and Westmorland, whose lands and properties were concentrated in county Durham, was considered "one of the leading northern magnates." 38

Because Lady Jane was a member of the royal household prior to her wedding, the queen, acting in loco parentis, had the right to approve her marriage. Moreover, due to kinship ties, the intimacy created through long-term privy chamber service, and the royal permission required to leave court, it is virtually certain that Elizabeth would have been aware of Lady Jane's marriage to Westmorland. The location of the wedding ceremony is unknown but, because Lady Jane had been serving at court, it is possible that it took place in London. No details survive which chronicle Elizabeth's handling of the union. Furthermore, it is not evident that Elizabeth established an obvious bond with Westmorland and Lady Jane as a couple. Such a bond might have been accomplished through a supportive patron-client relationship which would have formally recognised the lateral connection between or joining of the Neville and Howard families, drawn both kin groups' allegiances towards the crown rather than towards each other, and upheld the prevailing hierarchy.

35 Merton, 262; Kinney, ed., 33, 252; Nichols, Elizabeth, vol. 1, 37.

36 W. A. Sessions, Henry Howard the Poet Earl of Surrey: A Life (Oxford: Oxford University Press, 2003), 204; Cuthbert Sharp, Memorials of the Rebellion of 1569 (London: John Bowyer Nichols and Son, and William Pickering, 1840), 305306. Elizabeth mother, Queen Anne Boleyn, was executed in 1536. Lady Jane's father, Henry Howard, earl of Surrey, was executed for treason in 1547.

37 It was either shortly before or after the wedding that Charles, lord Neville, became the sixth earl of Westmorland, the fifth earl having died in February 1564.

38 Sessions, 205; ODNB, s.v. "Neville, Charles, sixth earl of Westmorland." 
In terms of noble weddings of the Elizabethan age, it seems that the Westmorland-Howard marital alliance would have been one of great significance. Already stated are the multiple ties between Lady Jane and the queen, that she was sister to England's only duke, and a member of one of England's wealthiest and most powerful peerage families. Based on her prestigious societal position and undoubted cachet within the noble marriage market, Lady Jane's matrimonial union with a prominent, northern Catholic noble family presumably would have been a much-discussed, if not controversial alliance. Westmorland had been raised in the Catholic faith. ${ }^{39}$ While her wider family network included Catholics and Catholic-sympathisers, Lady Jane had been educated by Protestant tutors, yet her religious beliefs are less clear. Retha Warnicke and others have suggested that she remained Protestant throughout her life, while W. A. Sessions has described her as a recusant. ${ }^{40}$ Either way, Lady Jane's association with the Nevilles entrenched her firmly in a world of practicing Catholics. Without any deep concern for religion, ${ }^{41}$ Westmorland likely would have expected that by marrying the queen's cousin he would be brought closer to valuable crown patronage. Lady Jane would have served as a critical link that joined the influential Nevilles to the queen to foster stronger ties between county and court, north and south.

One year after the wedding, Francis Russell, second earl of Bedford, reported to Burghley on Westmorland's excellent service to the queen and country: "My lord of Westmorland and the rest were so honourable and so forward for that service [protecting the Borders] as could be devised." 42 From October 1566 to January 1567 the earl was in London for Elizabeth's third Parliament. He was appointed along with other noblemen to meet with the queen twice and he served on at least one bill committee. ${ }^{43}$ In January, as the queen "came by Water from Whitehall, and Landed on the backside of the ParliamentChamber" for Parliament's final meeting, she was met by Westmorland who

\footnotetext{
39 ODNB, s.v. "Neville, Charles, sixth earl of Westmorland;" Daniel Rowland, An Historical and Genealogical Account of the Noble Family of Nevill (London: Samuel Bentley, 1830), 44.

40 Retha M. Warnicke, Women of the English Renaissance and Reformation (Westport, CT: Greenwood Press, 1983), 166; K. J. Kesselring, The Northern Rebellion of 1569: Faith, Politics, and Protest in Elizabethan England (Basingstoke and New York: Palgrave Macmillan, 2007), 191n; Henry Granville Fitzalan-Howard, Duke of Norfolk, The Lives of Philip Howard, Earl of Arundel, and of Anne Dacres, His Wife (London: Hurst and Blackett, 1857), 175; Sessions, 205.

41 Westmorland did not want the Northern Rebellion to be based on religion. See CSPD, Addenda, 1566-1579, 404.

42 BL, Cotton MSS, Caligula B/X fol. 345; Sharp, Memorials, 289.

43 D'Ewes, 96, 101, 102, 103, 108.
} 
carried the sword of state before her, ${ }^{44}$ "an honour usually reserved for a near relative of the monarch." 45 Once Elizabeth was "Apparelled in her Parliament Robes... the Earl of Westmorland [stood with] the Sword at her left hand." 46 Over this four-month period in London, the queen would have had multiple opportunities for contact with Westmorland. She did bestow upon him the express honour of leading her into Parliament's closing ceremony, but this was an insubstantial effort at promoting his inclusion.

The following year, on 23 August 1568, the earl was commissioned again by Elizabeth to muster troops: "Upon the disorders committed upon the opposite borders in Scotland... You are immediately to cause the said 100 horsemen to be levied, and put in readiness." 47 Westmorland fulfilled the commission and had responded by 7 September that he and the Bishop of Durham had "diligently... put in readiness" the mounted troops. However, in what was a foretelling statement describing the frustrations of county Durham's inhabitants, and perhaps the earl himself, Westmorland did "complain of the hardship of the inhabitants of the Bishopric being constantly liable to serve without recompense." 48 For his services to the queen-regular border protection and keeping of peace-it does not appear that Westmorland gained any recognition or remuneration beyond his ceremonial role in Parliament's closing in 1567. Westmorland received none of the government appointments his father did. In contrast, the fifth earl had successfully served three Tudor monarchs in various capacities and was rewarded by Mary I with grants of land in Lincolnshire and Yorkshire. ${ }^{49}$

Westmorland was not the only northern earl troubled by the lack of meaningful crown patronage or acknowledgment. His neighbour Thomas Percy, seventh earl of Northumberland, had fared similarly under the Elizabethan regime. Northumberland, a Catholic, was not included among the northern nobility appointed to attend upon the queen at her coronation despite his upper-level status and considerable regional influence, though in 1563 the queen did honour

${ }^{44} \mathrm{Ibid}, 113$.

45 Doran, Circle, 45.

46 D'Ewes,113.

${ }_{47}$ CSPD, Addenda, 1566-1579, 53.

48 CSPF, 1566-1568, 544.

49 ODNB, s.v. "Neville, Ralph, fourth earl of Westmorland." Henry Neville, fifth Earl of Westmorland, served during the reigns of Henry VIII, Edward VI, and Mary I. His positions included member of the council of the north, privy councillor, ambassador to Scotland, lord-lieutenant of Durham, and lieutenant-general of the north. 
him with the Order of the Garter. ${ }^{50}$ Nonetheless, via the courts Elizabeth denied Northumberland a key source of income through the 1568 Case of the Mines pleading. The verdict declared that any mined gold and silver ore became the crown's property rather than the owner's, i.e., Northumberland. ${ }^{51}$ Since many of England's mines lay in the outer reaches of the realm where the subjects remained largely Catholic or Catholic-sympathising, this verdict became a way for the Elizabethan government to prevent recusants from amassing wealth. ${ }^{52}$

As members of the nobility, Westmorland and Northumberland had substantial estates to manage, many retainers for whom they were responsible, and whom they patronised in turn. ${ }^{53}$ Such was the hierarchical social system in early modern England as well as the duty of members of the aristocracy and it required considerable means. It became more difficult for them to provide for their estates effectively due to the lack of monarchical patronage such as government positions, crown leases, or monopolies. So bleak was his financial situation in 1568 that Westmorland had to borrow $£ 80$ from local gentleman Sir George Bowes. ${ }^{54}$ The same opportunities that had been available to their forebears were refused them. Stephen Alford has noted that they "did not have the luxury of being able to express their own medieval and magnate identities." Because Northumberland and Westmorland "were on the periphery" of Elizabethan government rather than part of it like their predecessors, they were "effectively excluded." 55 This exclusion revealed an underlying discontent and distrust between the queen and the northern earls which relates to Larson's belief that "Parties in conflict can find ample justification for their beliefs that the other cannot be trusted."56 When Elizabeth closed off both earls to the financial support and royal recognition equivalent to their positions, conflict grew because their livelihoods, ranks, and regional influence were being denied by and subordinated to the crown. As a result, from 1568 the earls' attention turned to another queen,

\footnotetext{
50 Nichols, Elizabeth, vol. 1, 37; ODNB, s.v. "Percy, Thomas, seventh earl of Northumberland."

51 Plowden, Commentaries, vol. 1, 316.

52 BL, Lansdowne MSS, Vol/5 fol. 151.

53 K. J. Kesselring, "Mercy and Liberality: The Aftermath of the 1569 Northern Rebellion," History 90 (2005): 224; Mervyn James, Society, Politics and Culture: Studies in Early Modern England (Cambridge: Cambridge University Press, 1986), 274-275; ODNB, s.v. "Neville, Charles, sixth earl of Westmorland."

54 Sharp, Memorials, 290n.

55 Alford, 206.

56 Larson, 41.
} 
the deposed Catholic Mary, queen of Scots, northern England's new resident monarch-prisoner.

Mary's presence in England shaped court politics and discussions from which a plan emerged for the Scots queen to marry the now thrice-widowed duke of Norfolk. A Norfolk-Mary marriage would have resolved dual problems of succession and Mary's inconvenient exile, and it "gained the support of a group of substantial nobility" including Leicester. ${ }^{57}$ In late 1569 rumours circulated in the north regarding the Norfolk-Mary marriage and a return to Catholicism, both of which created civil unrest. ${ }^{58}$ When commanded to present themselves before the queen in London to answer questions regarding the disorder in the north, Northumberland and Westmorland refused and raised the short-lived Northern Rebellion. ${ }^{59}$ The disorganised uprising had multiple aims as Northumberland later admitted:

Our first object in assembling was the reformation of religion and preservation of the person of the Queen of Scots, as next heir, failing issue of Her Majesty, which causes I believed were greatly favoured by most of the noblemen of the realm.

Reporting to the Privy Council in his capacity as head of the Council of the North, Sussex confirmed that "They intend to make religion their ground." 60 Alford has also stated that "Religion was the key to recruitment in the rising, and not feudal loyalty, but the reverse is true of the earls' general motives." 61 Westmorland, however, preferred that any revolt not be based on religion. ${ }^{62}$ Still county Durham, the earl of Westmorland's sphere of influence, became the "heart of the rebellion" where signs of the reformed religion were removed and Catholic mass celebrated at Durham Cathedral.63 But with a southern army approaching, the rebel earls retreated and fled to Scotland. They were charged with treason and attainted, stripped of their titles and lands. ${ }^{64}$ Northumberland was captured, returned to

\footnotetext{
57 Fletcher and MacCulloch, 102, 109.

58 TNA, SP $15 / 15 / 6$.

${ }^{59}$ For fuller accounts of the Northern Rebellion see Fletcher and MacCulloch, 101-114; Kesselring, Northern Rebellion; Sharp, Memorials.

60 CSPD, Addenda, 1566-1579, 407, 107

61 Alford, 206.

62 CSPD, Addenda, 1566-1579, 404.

63 Fletcher and Macculloch, 104.

64 SR, vol. 4, 549-552: 13 Eliz. I, 1571, c. 16.
} 
England, and executed in 1572. Westmorland later escaped to the Continent and never returned to England. ${ }^{65}$

After Westmorland's flight and the crown's confiscation of his property, the countess, with three young daughters to support, sought Elizabeth's mercy. While Lady Jane's role in the rebellion is unclear, after his capture, Northumberland intimated during interrogations that she had encouraged her husband to participate the uprising. ${ }^{66}$ The countess, however, wrote to the queen via Burghley, protesting her innocence. 67 Journeying south in winter from northern England, Jane of Westmorland was at Howard House, her brother Norfolk's London residence, by 23 March 1570, when she wrote asking Burghley "to be a suitor for me to the Queen's Majesty, to give me leave to come to her royal presence." 68 Despite the harsh punishments meted out upon the lower classes, Elizabeth showed mercy to her cousin. ${ }^{69}$ Lady Jane was granted a lease on Brancepeth Park and received an annual sum of $£ 200 .^{70}$ A royal commission investigating the countess's involvement in the rebellion found her not guilty ${ }^{71}$ despite accusations of her participation and incitement of the earls. ${ }^{72}$ In 1577, her per annum was increased to $£ 300$ for the upkeep of her daughters. ${ }^{73}$ Of additional note is that the earldom of Westmorland was not revived during Elizabeth's reign. This suggests that the queen kept it available should circumstances change and the earl make appropriate amends as the countess believed he could and should do. ${ }^{74}$

It appears that, despite a very personal connection, Elizabeth never acknowledged the Westmorland-Howard marital alliance which essentially ended after six years. With Lady Jane as a link, the queen had an immense opportunity to bring into the courtly fold a northern Catholic family with considerable property and influence. But the Northern Rebellion made it obvious that Elizabeth had completely failed to manage effectually, to crown benefit, her own kinswoman's

\footnotetext{
65 Cokayne, ed., vol. 8, 115.

66 Sharp, Memorials, 199, 202, 207, 212, 307.

${ }^{67}$ BL, Lansdowne MSS, Vol/12, fol. 61; Sharp, Memorials, 307-309.

68 BL, Lansdowne MSS, Vol/12, fol. 61; Wright, ed., vol. 1, 358, 400. Rather than leaving on her own, the countess may have been removed from the north. See CSPD, Addenda, 1566-1579, 222, 226.

69 Kesselring, Northern Rebellion, 124; Fletcher and Macculloch, 107; Sharp, Memorials, 133-135.

70 BL, Lansdowne MSS, Vol/18, fol. 200; Wright, ed., vol. 1, 400; Sharp, Memorials, 309n.

71 TNA, SP 15/20/104.

72 CSPD, Addenda, 1566-1579, 406-407; Sharp, Memorials, 307-309.

73 Sharp, Memorials, 309n; Warnicke, Women of the English Renaissance, 165-166.

${ }^{74}$ Kesselring, "Mercy and Liberality," 223; TNA, SP 15/17/59, 61.
} 
marriage. It is worth considering the possibility that Elizabeth's ostensible lack of engagement with the Westmorland-Howard marriage contributed to the uprising. According to K. J. Kesselring, the uprising found "its roots in elite power struggles."75 Other scholars have recognised the lack of the Elizabethan government's engagement with the region and patronage of the northern elite, ${ }^{76}$ noting the queen's "minimal gestures of inclusion."77 The social hierarchy depended upon patronage which "allowed the crown to cement the loyalty of the nobles, gentry and servants whose help it needed in order to rule effectively." 78 In a hierarchical era bound by patronage, Elizabeth did not appear to initiate a monarch-noble patron-client relationship with the Westmorlands, a couple who emphatically represented a unification of northern and southern families, the counties and the court, Catholicism and Protestantism. It is, thus, conceivable that the queen's exclusion of them contributed to the revolt.

\section{Norfolk-Leybourne, 1567}

Prior to the Northern Rebellion, Norfolk followed in his older sister Lady Jane's footsteps, increasing his influence in northern England through a marital alliance with Lady Elizabeth Leybourne. ${ }^{79}$ With Lady Margaret's death in 1564, the duke was considered to have "great influence" as "the most powerful man in the realm." He was also England's most eligible widower and by August 1566 was already considering a third marriage. Norfolk's third wife-to-be was the northern and "very Catholic" Lady Elizabeth Leybourne, widow of Thomas Dacre, fourth baron Dacre of Gilsland. ${ }^{80}$ Little evidence remains of their courtship though it appears to have been linked to Norfolk's guardianship of Lady Elizabeth's children who became royal wards after the death of their father. The duke received the queen's tentative approval for the Dacre children's guardianship even before Lord Dacre's passing. Valued at "8,000 crowns a year," it is understandable that Norfolk would have been keen to assume control over the Dacre heirs' estates but,

\footnotetext{
75 K. J. Kesselring, “'A Cold Pye for the Papistes': Constructing and Containing the Northern Rising of 1569," Journal of British Studies 43 (2004): 442.

76 Kesselring, "Mercy and Liberality," 224; James, Society, Politics and Culture, 274-275; Alford, 206.

77 ODNB, s.v. "Percy, Thomas, seventh earl of Northumberland."

78 Kesselring, "Mercy and Liberality," 224.

${ }^{79}$ Norfolk already had ties to leading northern noblemen from due to his 1559 appointment to the position as lieutenant-general of the north. See Hayward, 48; Dennis E. Rhodes, "A Party at Norwich in 1562," Norfolk Archaeology 37 (1977): 116-120.

80 CSPSp, 1558-1567, 581, 571, 605; Richard S. Ferguson, A History of Cumberland (London: Elliot Stock, 1890), 167-168.
} 
according to Neville Williams, "at that time no-one dreamt of his marrying the Dacre widow."81 However, in late December Spanish ambassador Diego Guzman de Silva reported to King Philip II of Spain that he had been "advised in great secrecy that the marriage [between Norfolk and Lady Elizabeth] is being arranged and will be carried out." The secrecy was likely due to Lady Elizabeth's dedication to Catholicism and her kinship ties to many northern, Catholic families. Williams has described that Lady Elizabeth "brought with her [to London] a Roman Catholic chaplain and her own set of altar cloths and copes," indicating that she did not hide her faith. ${ }^{82}$

As with his first marriage, the duke sought prior monarchical approval. In addition, the queen technically had right of approval through the plural prerogative of widows' marriages, though Lady Elizabeth probably purchased a licence to remarry. The couple gave the queen four days' notice of their intended union. Queen Elizabeth later informed Guzman de Silva that she had not disclosed "the Duke's marriage" to the ambassador because "she had known nothing about it herself until that moment." This may or may not have been true; historical silence has veiled whether the queen gave her consent or not. The ceremony took place at the London home of Lady Elizabeth's mother on 29 January 1567.83 It is unlikely that the queen attended the ceremony as it took place "without any rejoicing or demonstration."84 Furthermore, with Lady Elizabeth and her mother both being "good and virtuous Catholics," one might conceivably wonder whether the marriage was celebrated according to Roman rites. ${ }^{85}$ In the end, the NorfolkLeybourne union was fleeting as Lady Elizabeth died on 4 September 1567 following complications from childbirth, fewer than eight months after the wedding.

Elizabeth most likely would have carefully considered the positive and negative implications of the Norfolk-Leybourne marriage. Despite Norfolk's position as the queen's kinsman, a supportive and loyal subject, a Protestant, and an important figure within the Elizabethan regime, she had ample reason to

81 CSPSp, 1558-1567, 571, 524-525; Williams, Norfolk, 127.

82 CSPSp, 1558-1567, 605; Williams, Norfolk, 127.

83 CSPSp, 1558-1567, 614, 616.

84 Williams, Norfolk, 127.

85 CSPSp, 1558-1567, 616 
disapprove of the wedding. ${ }^{86}$ The secret nature of the relationship along with Lady Elizabeth's adherence to Catholicism likely generated mistrust between the queen and Norfolk, discouraging her public support of their union. Indeed, Guzman de Silva believed that Norfolk might be easily persuaded to take up the Catholic cause, a belief the queen may have shared:

The Duke would be a great gain to [the Catholic] religion because, although he does not profess to be a Catholic himself, his advisers and others in this household are so, and these together with his wife, might easily bring him to a right way of thinking. ${ }^{87}$

Additionally, Norfolk had already been tentatively granted the guardianship of the Dacre children. There was no need for him to marry the widowed Lady Elizabeth as well. Bearing this in mind, the queen's silence surrounding the NorfolkLeybourne marriage seems meaningful. Because Norfolk and the queen were cousins, his marriage to Lady Elizabeth also became a personal kinship tie between his new wife and the queen. Norfolk's desire to establish close marital and kinship ties with a person whose continued devotion to the Roman religion stood against the Elizabethan Settlement was, in all probability, surprising and suspicious, notwithstanding the financial benefits garnered through the Dacre wardships.

At the same time, there was an aspect to the Norfolk-Leybourne marriage which was positive for the crown. Through his marriage to Lady Elizabeth the duke extended his outwardly pro-monarch, Protestant influence into the Catholic north of England. It was a move doubtlessly welcomed by the Elizabethan government in the long-term, especially since, according to Anthony Fletcher and Diarmaid MacCulloch, the "religious settlement had made little impact in the north during the 1560s."88 Any monarchical reservation over the Norfolk-Leybourne marital alliance might be overlooked in favour of the more critical goal of increasing authority over Catholic areas of the kingdom through the influence of the duke, and through the duke, the queen. Like Norfolk, Burghley had marriage kinship ties to the northern Catholic peerage families Neville and Percy. ${ }^{89}$ For the queen, having the regime's foremost peer and statesman, both Protestants, making

86 ODNB, s.v. "Howard, Thomas, fourth duke of Norfolk."

${ }^{87}$ CSPSp, 1558-1567, 605.

${ }_{88}$ Anthony Fletcher and Diarmaid MacCulloch, Tudor Rebellions, $6^{\text {th }}$ ed. (London and New York: Routledge, 2016), 112.

89 In 1564, Cecil's son, Thomas Cecil, later first earl of Exeter, married Dorothy Neville, daughter of John, third baron

Latimer, and sister-in-law to Sir Henry Percy, later eighth earl of Northumberland. See Cokayne, ed., vol. 5, 217. 
personal links into largely Catholic areas of the country was not only advantageous, but necessary to control and influence better those regions without burdening the exchequer. Yet the queen's lack of overt approval or participation in the Norfolk-Leybourne wedding can be viewed as an uncertainty which derived from its conflicting elements.

Norfolk's weddings to Lady Margaret and Lady Elizabeth underscored the importance of marriage for the amalgamation of assets and power. Shrewdly arranged to heiresses, the marriages ensured the duke's accumulation of property and wealth, thereby strengthening his position as England's most influential peer. Norfolk's alliances also illuminated the system of wardship and wards' marriages. Following Elizabeth of Norfolk's death, Norfolk acted quickly to retain properties that the duchess had received through lord Dacre, became guardian to the Dacre children, and then arranged their marriages to his own children. ${ }^{90}$ Few details remain of the marriages of Norfolk's sons to the daughters of Elizabeth of Norfolk. Philip Howard, styled earl of Surrey, later thirteenth earl of Arundel, ${ }^{91}$ was betrothed to his stepsister Lady Anne Dacre in 1569 when they both were 12 years old. ${ }^{92}$ A discussion of the Arundel-Dacre marriage follows. After Norfolk's execution in 1572 for his role in the Ridolfi plot, ${ }^{93}$ sons Thomas and William Howard married Ladies Mary and Elizabeth Dacre, respectively, in 1577, according to their father's wishes. ${ }^{94}$ The queen's reaction to these marital unions is not known as there is no evidence of her acknowledgement of them. The latter two Howard-Dacre marriages were likely deemed non-threatening. Norfolk's attaintment due to treason stripped his sons of their societal positions and courtesy titles; they were no longer the sons of a peer. As it happened, Thomas Howard's marriage was brief with Lady Mary passing away in 1578. Nevertheless, had Norfolk lived, the intermarriage of his children and step-children would have

${ }^{\circ} C P R, 1566-1569$, 38-39, 431; Ferguson, 168. Arundel and Lady Anne sued for livery on 19 November 1579. See CPR, 1578-1580, 205.

91 Strype, Ecclesiastical Memorials, vol. 5, 141-142.

92 Cokayne, ed., vol. 1,255. This marriage is discussed further in chapter five.

93 George T. Matthews, ed., News and Rumor in Renaissance Europe: The Fugger Newsletters (New York: Capricorn Books, 1959), 42, 128.

${ }^{94}$ For Norfolk's final letter to his children see Wright, ed., vol. 1, 402-412. Thomas Howard and Lady Mary Dacre were married by May 1577. See HMC, Report on Manuscripts in Various Collections, vol. 2 (London: H. M. Stationery Office, 1903), 233; Cokayne, ed., vol. 12/1, 465. William Howard and Lady Elizabeth Dacre were married on 28 October 1577. See $O D N B$, s.v. "Howard, Lord William." 
served "to secure the devotion of the whole north country to his house," which was likely the duke's goal. ${ }^{95}$

\section{Arundel-Dacre, 1571}

As mentioned in the previous case study, Norfolk had numerous "plans and achievements" regarding the wardships and marriages of his children and stepchildren. ${ }^{96}$ To meet those ends, he organised the aforementioned 1569 betrothal of his son Philip, earl of Arundel, ${ }^{97}$ to his stepdaughter and royal ward Lady Anne Dacre. ${ }^{98}$ Two years later the duke ensured that the contract between the young couple was formalised in marriage when they reached fourteen, the age of consent.99 The Arundel-Dacre wedding was conducted with "sufficient witnesses and other requisite conditions" but commemorated "privately without any noise or public solemnity by reason the Duke at the time was in disgrace." 100 This celebration stands in stark contrast to the Oxford-Cecil and Herbert-Hastings double wedding of the same year which was graced by Elizabeth as described in chapter three. It is unclear if the queen gave her consent and nor is there any evidence of her reaction. As the premier peer, it would seem reasonable, even expected, that Norfolk would obtain the queen's approval for the marriage of his young heir to a royal ward under his guardianship.

Several historians have claimed that this marriage was clandestine, arranged "by an urgent order of the Duke," then imprisoned for his role in the Ridolfi plot, "lest the Queen should peremptorily annul the betrothal and forbid their union."101 I have found no information which suggests that the wedding was clandestine or that Norfolk was concerned that Elizabeth might block the marriage. It was common practice for guardians to marry their wards to their own children for the consolidation of properties and wealth. The duke may have, however,

\footnotetext{
95 CSPSp, 1580-1586, 315. See also Stone, Crisis, 601.

${ }^{96}$ Hurstfield, Queen's Wards, 144.

97 Strype, Ecclesiastical Memorials, vol. 5, 141-142.

98 Cokayne, ed., vol. 1, 255; Fitzalan-Howard, 173. Philip Howard lost the courtesy title "earl of Surrey" when his father Thomas Howard, fourth duke of Norfolk, was attainted and executed for treason in 1572. But he inherited the earldom of Arundel through his mother in 1581. Despite his differing designations, I have referred to him as Arundel throughout to avoid confusion and because it was it ultimate title.

${ }_{99}$ Cokayne, ed., vol. 1, 255; Fitzalan-Howard, 10; ODNB, s.v. "Howard, Philip [St Philip Howard], thirteenth earl of Arundel."

100 Fitzalan-Howard, 174.

101 Gerald Brenan and Edward Phillips Statham, The House of Howard, vol. 2 (London: Hutchinson \& Co., 1907), 461;

Fitzalan-Howard, 10; Cokayne, ed., vol. 1, 255.
} 
taken advantage of the technicalities of wardship. Hurstfield has explained that if a ward had passed age fourteen and was already officially betrothed or wed, "the crown could not offer an alternative marriage."102 Since Arundel and Lady Anne had reached the age of consent and the marriage was canonically valid, there was little the queen could do apart from forcibly separating the young couple and annulling their union through the courts-an action Elizabeth had already undertaken in response to objectionable weddings. ${ }^{103}$ Despite Norfolk's incarceration, such a decision would likely have been unwise due to the duke's political power and influence. Thus, Elizabeth did not express opposition to the lateral connection instituted by the marriage, but nor did she show it favour.

Several years after his father's execution Arundel began living at court in an attempt "to win Elizabeth I's favour;" ultimately, "He was unsuccessful in his pursuit of royal patronage." Extensive financial outlay for court dress, tournaments, and entertainments, which included hosting the queen, did not connect him with the crown support he sought and "he left court in disgrace." 104 In 1581 he was restored in blood following his accession to the earldom of Arundel. ${ }^{105}$ Nevertheless, the long-term isolation from monarchical recognition and financial provision may have led the earl to convert to Catholicism in 1584, following the conversion of his wife. ${ }^{106}$ When Arundel attempted to flee England without licence in 1585, he was captured, "taken before the Queen," 107 and "lodged in the Tower."108 Attainted in 1589 for treason in the queen's prerogative court Star Chamber, ${ }^{109}$ he remained incarcerated for eleven years, dying a suspicious death which the Spanish ambassador had prophetically "feared" would happen years earlier. ${ }^{110}$

Elizabeth's circumspect and detached behaviour towards Arundel and Lady Anne suggested an underlying distrust which may have originated from both

\footnotetext{
102 Hurstfield, Queen's Wards, 155, 156, 137, 144-145.

103 Fitzalan-Howard, 10, 174. See the 1560 Hertford-Grey and 1565 Keys-Grey marriages discussed in chapter five. 104 ODNB, s.v. "Howard, Philip, thirteenth earl of Arundel;" Cole, 191, 194.

105 SR, vol. 4, 657: 23 Eliz. I, 1581, c. 19; CSPSp, 1580-1586, 90; Cokayne, ed., vol. 1, 254.

106 CSPSp, 1580-1586, 577; Fitzalan-Howard, 27; Cokayne, ed., vol. 1, 254; ODNB, s.v. "Howard, Philip, thirteenth earl of Arundel."

107 CSPSp, 1580-1586, 537.

108 Ibid, 538; TNA, SP 12/215/42.

109 TNA, SP 12/223/127-135; CP, Vol. 284/2.

110 CSPSp, 1580-1586, 542. In 1585, following the alleged suicide of Henry Percy, eighth earl of Northumberland, in the Tower, Ambassador De Mendoza wrote that Northumberland's death had been ordered "by the councillors, and it is to be feared that they may do the same thing to the earl of Arundel and other Catholic prisoners."
} 
Norfolk's disloyalty, his possibly evasive arrangement of their marriage, and the danger the bond between the Howard and Dacre families posed to her monarchy. These factors were exacerbated by the couple's conversion to Catholicism in a decade of increased Catholic plotting and heightened conflict with Spain. ${ }^{111}$ The queen's exclusion and denial of patronage, despite the earl's efforts to gain her support, indicated that she might not have sanctioned his marital union in the first place. Moreover, because Norfolk was imprisoned in the Tower for treasonous crimes at the time of the Arundel-Dacre marriage, his suitability as a guardian to determine an appropriate spouse for Lady Anne was questionable. This lends weight to the supposition that Elizabeth might have opposed and attempted to prevent the union from occurring had she foreseen Norfolk's intentions. The crown conceivably would have re-assumed Lady Anne's wardship and forced a different marriage contract for her. Matching Arundel and Lady Anne with lesserranked, Protestant pro-monarch partners would have separated the Howard heir from the Dacre family, broken their connection, nullified any danger they might have presented, and diminished their positions and influence in the north. Instead, Arundel and Lady Anne were bound together, becoming magnets for treasonous Catholic activity which proved a concern to the Elizabethan regime during Arundel's lifetime. ${ }^{112}$

\section{Strange-Spencer, 1579}

Upper-level noble marriages involving Catholics continued into the late 1570s, but the marriage of potential heir to the throne Ferdinando Stanley, styled lord Strange, later fifth earl of Derby, to Alice Spencer, daughter of Sir John Spencer of Althorp, Northamptonshire, interestingly, provoked no monarchical response. ${ }^{113}$ The wedding took place in 1579 but its exact date and location are unclear. No evidence has been uncovered which suggests that Elizabeth played any part in its

111 CP, Vol. 242/1; Fitzalan-Howard, 31-51.

112 CSPSp, 1580-1586, 603-604. De Mendoza wrote that Arundel supported Philip II and the Catholic cause. See also $O D N B$, s.v. "Howard, Philip, thirteenth earl of Arundel." According to ODNB, Arundel harboured Jesuit priests Thomas Heywood and William Weston. Along with his support of Jesuits, Arundel caused disorder in the Tower. See CSPD, 1595-1597, 568.

113 Due to his brief, six-month term as the fifth earl of Derby and so as not to confuse him with his father, the fourth earl, Ferdinando Stanley has been referred to as his courtesy title, lord Strange, throughout this section, rather than his terminal title. 
celebration. ${ }^{114}$ However, it seems that three earls were in attendance. ${ }^{115}$ That it was an unequal marriage in terms of rank-the heir to an earldom marrying "the daughter of a mean knight" - may have been offensive to the queen, accounting for the silence of the historical record. ${ }^{116}$ The lateral connection inaugurated by the marriage brought two important families together, possibly causing Elizabeth's reticence. Moreover, two historians have suggested that the Strange-Spencer marriage was actually clandestine and unauthorised by the queen, ${ }^{117}$ but this weighty speculation is uncited and left unmentioned in several other sources. ${ }^{118}$

Louis Knafla has alleged that the new Lady Strange "entered the queen's household and became prominent at court."119 If this was the case, such a postwedding show of monarchical support would have been an act reminiscent of the queen's invitation to Margaret of Norfolk. It would also have been a distinct mark of royal acceptance and patronage with Elizabeth publicly acknowledging the joining of the Stanley and Spencer families. Conversely, however, Arthur Kinney, Jane Lawson, and Charlotte Merton have not indicated that Lady Strange was a member of Elizabeth's chamber staff. ${ }^{120}$ The queen's failure to appoint Lady Strange to the royal household suggests her non-recognition of the StrangeSpencer marriage. It also supports a silent response to the union, indicating that Elizabeth preferred to keep the newlyweds at the periphery rather than embrace them openly. Adopting a wait-and-see approach allowed the queen to distance herself from the questionable marriage until its long-term outcome became evident.

Similar to previous interdenominational marriage examples, this wedding joined the Stanleys, an upper-level noble family, with the wealthy, gentry-level Catholic Spencer family. Because they "lived in the most Catholic area of England," Lancashire, the Stanleys were considered by some to be Catholics or Catholicsympathisers. ${ }^{121}$ But Henry, the fourth earl, was a committed Protestant, a faithful

114 Cokayne, ed., vol. 4, 212; Thomas Heywood, The Stanley Papers, Part I (London: Printed for the Chetham Society, 1853), 30; French R. Fogle and Louis A. Knafla, Patronage in Late Renaissance England (Los Angeles: University of California, 1983), 9.

115 CP, Vol. 203/150.

${ }_{116}$ CSPD, Addenda, 1580-1625, 138

117 Fogle and Knafla, 9; ODNB, s.v. "Spencer [married names Stanley, Egerton], Alice, countess of Derby."

118 Heywood, 30; Cokayne, ed., vol. 4, 212; ODNB, s.v. "Stanley, Ferdinando, fifth earl of Derby."

119 ODNB, s.v. "Spencer, Alice, countess of Derby."

120 Anne Spencer is not mentioned as being a member of Elizabeth's household in either Merton or Kinney.

121 J. J. Bagley, The Earls of Derby 1485-1985 (London: Sidgwick \& Jackson, 1985), 65. 
servant of the queen, and an enforcer of her religious policies in the north where his estates lay. ${ }^{122}$ Before his marriage Strange had served as a squire in Elizabeth's court, and, like his father, he "was certainly no Catholic himself," being "firmly attached to the Church of England," as his later actions would suggest. ${ }^{123}$ Strange's mother Margaret Clifford, countess of Derby and a possible claimant to the throne, had also served the queen as a gentlewomen of the privy chamber from 1558 until 1579.124 But in 1579 her relationship with Elizabeth became strained when she faced allegations of gossip and conjuring to determine the date of the queen's death. ${ }^{125}$ While Strange and his father were supportive of the Elizabethan regime, the countess's disloyalty and threatening behaviour may explain an apparent lack of royal involvement in the Strange-Spencer wedding.

On the other hand, Spencer's father Sir John had obvious Catholic leanings. He was knighted at Mary I's coronation and served as an MP twice during her reign. Once Elizabeth ascended the throne he no longer served in government, likely due to his Catholicism. In 1564 Sir John was accused of being a "'great letter [hinderer] of religion' and ten years later Mary Stuart's agent accounted him a Catholic."126 Based on Sir John's background, it is not surprising that some might view warily the Strange-Spencer union. More practically speaking, though, the Stanleys were deeply in debt and Sir John was a wealthy man who was able to offer a large dowry in exchange for a connection to a noble family. ${ }^{127}$ In fact, so dire was the Stanleys' financial situation that the Privy Council had to intervene. The Council requested that the lord mayor of London persuade creditors to refrain from pressuring the Stanleys for repayment.128 Spencer's dowry would have helped to alleviate some of that financial burden and remove the need for government involvement in the noble family's difficulties, an aspect surely welcomed by Elizabeth and her councillors.

122 TNA, SP 12/141/51; CSPD, Addenda, 1566-1579, 321; CSPSp, 1568-1579, 229; ODNB, s.v. "Stanley, Henry, fourth earl of Derby."

123 CP, Vol. 158/147; TNA, SP 12/66/109; Bagley, 53, 65. See also Barry Coward, The Stanleys, Lords Stanley and Earl of Derby, 1385-1672 (Manchester: Manchester University Press, 1983), 145-146.

124 TNA, SP 12/66/109; CSPD, Addenda, 1566-1579, 43; Bagley, 55; Kinney, ed., 26. As a granddaughter of Mary Tudor, Henry VIII's younger sister, Margaret Clifford was a claimant to the throne through the Suffolk line. 125 CSPSp, 1568-1579, 692-693.

${ }^{126}$ S. M. Thorpe, "SPENCER, Sir John (1524-86), of Althorp, Northants. and Wormleighton, Warws," The History of Parliament, accessed 14 December 2019, http://www.histparl.ac.uk/volume/1509-1558/member/spencer-sir-john1524-86.

127 CSPD, Addenda, 1566-1579, 34; Coward, 31-32.

${ }^{128} A P C, 1578-1580,415$. See also Wright, ed., vol. 2, 356-357. 
Departing from the above examples in which Elizabeth had an established right of approval over the marriage, she enjoyed no such privileges over the Strange-Spencer match. Both Strange's and Spencer's parents were still living so they were not royal wards. Neither Strange nor Spencer was serving in the queen's household prior to their marriage so Elizabeth did not act in loco parentis. Thus, a potential explanation for absence of evidence of crown involvement is that the monarch had no right to intervene, even if she had desired it. Of greater significance, however, was that Strange could be considered second-in-line to the throne at the time of his marriage, just after his mother. Despite Strange's position as a potential successor, the queen was powerless to control his marital alliance. The 1536 Treason Act, which would have given Elizabeth the ability to manage the marriages of claimants to the throne, had been repealed long ago. She had no recourse for managing a possible heir's alliance prior to its occurrence. Though no evidence exists, Strange, considering his proximity to the throne, should have shown respect for his sovereign by informing her of his wedding.

In addition, because Elizabeth was in the midst of her own marriage negotiations with the French Catholic François, duke of Anjou, the Strange-Spencer union might not have provoked her interest or comment. The Elizabeth-Anjou marriage negotiations had begun in 1572 and continued into 1581. According to Doran, by 1579 the Privy Council generally supported the Anjou match and the queen was prepared to receive Anjou's suit in earnest. Elizabeth was deeply enamoured of and clearly distracted by the French duke as Doran has described: "During his visit and beyond Elizabeth played the role of a woman in love, carrying around with her Anjou's miniature in her prayer-book and writing him a poetic lament on his departure."129 Elizabeth's marriage to Anjou was a very real possibility which gave the queen and her Privy Council much to discuss while it also highlighted the succession question. ${ }^{130}$ Considering these factors, Elizabeth's apparent lack of acknowledgement of or involvement in the Strange-Spencer wedding seems odd since the earl was one conceivable successor. Though, if Elizabeth had eventually married and produced an heir, Strange's claim would have become more distant.

129 Doran, Monarchy, 163, 156.

130 CP, Vol. 148/47; Natalie Mears, "Love-making and Diplomacy: Elizabeth I and the Anjou Marriage Negotiations, c.1578-1582," History 86 (2001): 448. 
Lord Strange's fidelity to the queen came under question when, after the death of his father in September 1593, Catholic plotters targeted him for participation in a traitorous scheme. ${ }^{131}$ In October, one Richard Hesketh attempted to convince Strange, now fifth earl of Derby, to claim the throne. ${ }^{132}$ Lord Strange turned Hesketh over to the authorities and he was later executed. ${ }^{133}$ Prior to and during the Hesketh plot investigation, Strange's loyalty to Elizabeth had been unfaltering. There was no suggestion that he wanted to usurp the throne or that he was supportive of the Catholic cause. ${ }^{134}$ His actions following the revelation of Hesketh's scheme contradicted rumours of his Catholic leanings and demonstrated his support of Elizabeth and, by extension, the Church of England. Nonetheless, the Hesketh plot did alter the nature of the relationship between Elizabeth and Lord Strange. Notwithstanding his overt display of loyalty, Elizabeth wanted Strange questioned independently to prove that he had had no private dealings with Hesketh. ${ }^{135}$ The Privy Council later cleared Strange of any wrongdoing.

Around the time of the Hesketh plot Elizabeth was considering Strange for the lord-lieutenancy of Lancashire and Cheshire as well as the chamberlain of Chester, posts traditionally held by the earl of Derby and which had been held by his father. ${ }^{136}$ Strange had already served the Elizabethan regime in several capacities: as mayor of Liverpool in 1585, temporary lord-lieutenant of Lancashire and Cheshire around 1588, and in the House of Lords in 1589.137 After his father's death Lord Strange was appointed as Lord of Man, a title traditionally held by the Stanley family as protectors of the Isle of Man. ${ }^{138}$ Strange wrote to Burghley and his son, Sir Robert Cecil, asking them "to move her Majesty... to bestow the office of the Chamberlainship of Chester."139 It seems that Burghley did desire Strange's

\footnotetext{
131 CP, Vol. 170/65; ibid, Vol. 29/74; CSPD, 1591-1594, 534; Thomas Birch, ed., Memoirs of the Reign of Queen Elizabeth, vol. 1 (London: A. Millar, 1754), 145; Fogle and Knafla, 18. 132 CP, Vol. 170/65; ibid, Vol. 170/70; ibid, Vol. 29/74; CSPD, 1591-1594, 475. 133 CSPD, 1591-1594, 475; ODNB, s.v. "Stanley, Ferdinando, fifth earl of Derby."

134 John Seacome, The History of the House of Stanley (Preston: E. Sergent, 1793), 164; Thomas William King ed., Lancashire Funeral Certificates (Manchester: Printed for the Chetham Society, 1869), 68.

135 CP, Vol. 170/17; Bagley, 66.

136 Bagley, 66; Kinney, ed., 8, 57, 59, 104.

137 ODNB, s.v. "Stanley, Ferdinando, fifth earl of Derby."

138 Kinney, ed., 8.

139 CP, Vol. 23/60. See also ibid, Vol. 23/68; ibid, Vol. 23/91; ibid, Vol. 170/24.
} 
appointment to that post, conveying his own belief in the earl's trustworthiness, but the suit was unsuccessful. ${ }^{140}$

Whether or not the emergence of the Hesketh plot caused Elizabeth to bypass Strange for the lord-lieutenancy of Lancashire and Cheshire is unknown, though it seems plausible. ${ }^{141}$ According to Barry Coward, while "Lieutenants possessed great social prestige and influence, their duties... were heavy" with providing "the military needs of the crown." Lancashire and Cheshire, in particular, were "strategically important to the defence of England" due to their immediacy to Scotland and Ireland. ${ }^{142}$ When Elizabeth excluded Strange from important roles within his sphere of influence, it suggested that she lacked confidence in his loyalty. It is reasonable that despite his previous allegiance, Elizabeth believed that Strange would continue to be a rallying point for disaffected subjects, Catholics in particular, as the Hesketh plot had shown. Indeed, Burghley had been aware at least since 1591 that Catholics on the continent were targeting Lord Strange for support. ${ }^{143}$ What most likely tipped the scales against Strange was that he possessed a near claim to the throne which only made him seem more threatening.

In light of this later treatment, Elizabeth's non-participation at the StrangeSpencer marriage now appears more meaningful, and showcases a particular characteristic of her monarchy. The queen repeatedly denied advancement to Catholics as seen in the Oxford-Cecil, Cumberland-Russell, Wharton-Clifford, and Westmorland-Howard marriages. Despite his proven allegiance, Strange's claim to the throne and his predominantly Catholic Lancashire domain coupled with his wife's Catholic family were ominous factors difficult to overlook. Even when the Privy Council confirmed Strange's innocence in the Hesketh plot, she circumvented her councillors' findings to discredit him. By withholding offices and terminating patronage, she protected herself, nullified his claim to the throne, and prevented him from developing any further influence. Despite the Spanish ambassador's erroneous perception, the reality was that Strange had little political following at

\footnotetext{
140 J. Payne Collier, ed., The Egerton Papers (London: John Bowyer Nichols and Son, 1840), 192

141 Bagley, 66.

142 Coward, 155.

143 CSPD, 1591-1594, 39; Coward, 145-146.
} 
court because much of his time was spent on his estates in the north. ${ }^{144}$ His greatest interests were theatre, literature, poetry, and physical pursuits. ${ }^{145}$ As it happened, Strange, who held the earldom of Derby for only six months, died in April 1594 after a mysterious and painful illness. His sudden demise was considered suspicious, perhaps induced by poisoning. ${ }^{146}$ This untimely death of a potential claimant helped to ease James VI's pathway towards the English throne.

\section{Jacobean case study}

\section{Argyll-Cornwallis, 1609}

When James was firmly settled upon the English throne, a prominent wedding took place in London which joined a Scottish Protestant earl with an English Catholic gentry bride. On 30 November 1609 at St. Botolph's without Bishopsgate, Archibald Campbell, seventh earl of Argyll, married his second wife Anne Cornwallis, daughter of Sir William Cornwallis of Brome, Suffolk. ${ }^{147}$ Although it is unclear how Argyll and Cornwallis became acquainted, the young woman was a co-heir to her father's estate and probably came to the marriage with a large dowry-an element certainly appreciated by the deeply indebted earl. ${ }^{148}$ Argyll, a powerful Highland magnate, was Justice General of Scotland and a member of the Scottish Privy Council. ${ }^{149}$ From the 1590s James employed the earl as an enforcer in the Highlands to subdue unruly clans and rebel Catholic earls like Huntly. In 1603 Argyll travelled south with James when he assumed the English throne and was described as having "carried himself here with much credit and to the k[ing's] contentment and never departed being in so good grace."150 His many years of

\footnotetext{
${ }_{144}$ CSPSp, 1580-1586, 604. Mendoza believed that Derby would be supportive of the Babington plot. See also King, ed., 65-66; Fogle and Knafla, 11.

145 Heywood, 30; Doran, Circle, 62; King, ed., 65. Derby engaged in "stag hunting, hawking and coursing... and probably practiced tilting in the south."

146 John Stow, The Annals of England (London: [By Peter Short, Felix Kingston, and George Eld] for George Bishop, and Thomas Adams, 1605), 1275; Seacome, 164.

147 A. W. Cornelius Hallen, The Registers of St. Botolph, Bishopsgate, London, vol. 1 (Edinburgh: T. and A. Constable, 1889), 44; Jane Cornwallis, The Private Correspondence of Jane, Lady Cornwallis; 1613-1644, ed. Richard Griffin, Baron Braybrooke (London: S. \& J. Bentley, Wilson, \& Fley, 1842), xxxvii. St. Botolph's without Bishopsgate was near Sir William Cornwallis's London residence.

148 ODNB, s.v. "Cornwallis, Anne, countess of Argyll." Creditors were still pursuing Argyll in 1616 and beyond. See RPC, 1613-1616, 439; James Maidment, ed., Letters and State Papers During the Reign of King James the Sixth (Edinburgh: Edinburgh Printing Company, 1838), 312.

149 RPC, 1616-1619, civ; Paul, ed., vol. 1, 346-347; Cokayne, ed., vol. 1, 201-202.

150 Quoted in Brown, Noble Power in Scotland, 190.
} 
loyal service ensured that he was "highly favoured by the court" and the king at the time of his wedding. 151

Due to his long-term association with Argyll, it seems very likely that James, who was in London at the time of the wedding, would have been aware of the earl's match to Cornwallis. ${ }^{152}$ I have located no evidence to suggest that the king acknowledged the marriage or was involved in any way; the historical record is silent. James was not listed among the wedding attendees. ${ }^{153}$ While the king did not have any power over the Argyll-Cornwallis union, either through plural prerogatives or acting in loco parentis, he had previously intervened in Argyll's and other Campbell family marriages. In 1603 James, through a series of peace-making matches, had united the feuding earls of Argyll, Huntly, and Moray by ordering the intermarriage of their children. ${ }^{154}$ That the king chose not to recognise publicly or patronise the joining of the Campbell and Cornwallis families is curious considering the earl's high rank, James's long history with Argyll, and his firm intercession in the marriages of Argyll's children from his first marriage. Moreover, as described in chapter three, James had required conversions to Protestantism before allowing several marriages to take place. Why did he not do the same for the Argyll-Cornwallis union? It is possible that Argyll's power, influence, and solid military experience may have prevented James from intervening to press the matter.

The Argyll-Cornwallis marriage was significant not only because of the earl's social standing, but also because it represented both a merger of England and Scotland and religions. By 1609 James's hopes of an administrative AngloScottish union and the creation of Britain had been defeated. Yet Scottish and English intermarriages continued to be supported by the king and lavishly celebrated at court as an extension of the royal prerogative to foment greater union. The Argyll-Cornwallis marriage, though an Anglo-Scottish one, neither took place at court nor was patronised by the king. One explanation may have been

${ }^{151}$ ODNB, s.v. "Campbell, Archibald, seventh earl of Argyll."

152 CSPD, 1603-1610, 561-567. Though James planned to leave court to go hunting on 20 November 1609 , it seems that he was in London from 21 November 1609 due to a sore foot, possibly from gout, and departed on 4 December for a hunting match.

153 Hallen, vol. 1, 44

154 Maidment, ed., 101; Calderwood, vol. 6, 205; Croft, King James, 32. See also TNA, SP 52/47/103. In 1591 James had attempted to forward a match between Argyll and the second duke of Lennox's sister. 
that the Argyll-Cornwallis union was interdenominational, an aspect which prevented it from being fêted by the king in a similar manner to the Hay-Denny or Somerset-Howard weddings, for example. The king's apparent silence may have indicated a disavowal of the marriage. Argyll had been reared in the Protestant Church of Scotland while Cornwallis was a practicing Catholic. ${ }^{155}$ Despite her father's conforming to the Church of England, Cornwallis's grandfather, the Catholic Sir Thomas Cornwallis, had been a privy councillor to Mary I. ${ }^{156}$ In the Elizabethan regime, Sir Thomas and his wider kin network were considered recusants. ${ }^{157}$

Late 1609 was an active time in the searching out and punishing of Catholic recusants. State papers for October and November 1609 contain more than fifteen entries which mention the identification and punishment of recusants, removal of their property, payment of fines, requests for pardon, and those not taking the oath of allegiance or attending church. ${ }^{158}$ James had already been accused of harbouring Catholics in his household and of being too lenient towards recusants. ${ }^{159}$ Bearing these factors in mind, to support overtly a powerful Highland earl's connection to a practicing Catholic from a well-known recusant family would not have effectively signalled the king's commitment to Protestantism and the Churches of England and Scotland. However, James did indirectly communicate approval of the match at a later date, albeit in private and through an intermediary. When the couple's first child was born in 1611, the king obliquely demonstrated patronage of the couple and their "British" heir who "was baptised in the King's Chapel at Greenwich." Though the king himself did not attend, "the Prince [Henry] being his substitute," the earl of Salisbury and the marchioness of Winchester were present as supporters. ${ }^{160}$

After the marriage, James continued to use Argyll and his strong-arm tactics for the suppression of recalcitrant clans: the MacGregors in 1611 and the

\footnotetext{
155 ODNB, s.v. "Cornwallis, Anne, countess of Argyll."

156 ODNB, s.v. "Cornwallis, Sir Thomas."

157 Ann Weikel, "Sins of the Fathers?: The Marriage of Mary Cornwallis," Recusant History 23 (1997): 17; Norman Jones, "Living the Reformations: Generational Experience and Political Perception in Early Modern England," Huntington Library Quarterly 60 (1997): 285.

158 CSPD, 1603-1610, 547-565.

159 Queen Anne, who most likely converted to Catholicism in the 1590s, had numerous Catholics in her household. See $O D N B$, s.v. "Anne [Anna, Anne of Denmark]." In addition, James was considering either a French or Spanish Catholic bride for his heir.

160 Rimbault, ed., 174; Brown, “Scottish Aristocracy,” 573.
} 
MacDonalds in 1615.161 Upon the subjugation of the MacDonalds in late 1615, Argyll, attempting to finalise his commission, appeared before the Scottish Privy Council in mid-December. He reported on his actions and accomplishments in subduing the MacDonalds, which he "did in the space of three months." However, due to his retention of troops beyond the period James had determined, the Council refused to fund the extra wages, leaving Argyll "to pay about $£ 7,000$ out of his own pocket."162 This was undoubtedly a frustrating result to what had been a royal commission promptly and effectively fulfilled. But, in a later show of regal favour, in 1617, Argyll joined James on his visit to Scotland, attended Privy Council meetings while in Edinburgh, and waited upon the king. ${ }^{163}$ Also during the Scottish visit, it was noted there that Argyll took "communion at Holyrood according to the Anglican, rather than the Scottish, rite."164 Argyll's actions caused some to question his religious sentiments since he had been raised in the Scottish kirk.

The earl had in fact undergone a religious transformation. Through the influence of Cornwallis Argyll steadily encountered numerous Jesuits, eventually converting to the Roman faith. ${ }^{165}$ By 1618, while requesting and receiving royal permission to seek the medicinal waters at Spa, the Argylls left for the continent. ${ }^{166}$ When they landed, the earl openly declared his conversion to Catholicism and assumed a position in the Spanish army in Flanders. Both acts shocked and angered James who quickly had the earl's travel licence revoked and ordered him to appear before the Privy Council within sixty days. When Argyll did not return as demanded, he was branded a traitor. ${ }^{167}$ A verse by contemporary Scottish poet Alexander Craig wittily described Argyll's treachery:

Now Earl of Guile [Argyll] and Lord Forlorn thou goes,

Quitting thy prince to serve his Spanish foes,

No faith in plaids, no trust in highland trews,

Chameleon-like, they change so many hues. ${ }^{168}$

$161 R P C, 1610-1613,281 ;$ ibid, 1613-1616, 744-745

162 RPC, 1613-1616, 762-765, 757; Paul, ed., vol. 1,348. Argyll had been commissioned as His Majesty's “Lieutenant over the Iles."

$163 R P C, 1616-1619$, xcix-ci.

164 ODNB, s.v. "Campbell, Archibald, seventh earl of Argyll."

165 Four of Argyll and Cornwallis's daughters would later enter holy orders. See Brown, Noble Society in Scotland, 114.

166 Paul, ed., vol. 1, 348-349.

167 RPC, 1616-1619, 507-508, 467-468; See also CSPD, 1619-1623, 107; ODNB, s.v. "Campbell, Archibald, seventh earl of Argyll."

168 Quoted in John Scot, The Staggering State of Scottish Statesmen from 1550-1650 (Edinburgh: William Paterson, 1872), 40. 
But, despite Argyll's betrayal, in less than three years James had "the sentence of outlawry... reversed, and he was declared to be once more a loyal subject."169 This ostensible rehabilitation was only for show; Argyll did not perform any further duties for his king. As James himself commented, "I'll never trust any of my Subjects of... Scotland, that out of Discontent will go to serve the King of Spain."170

Argyll had served James for many years and been entrusted with military responsibilities important for the extension of royal authority. It was probably after the 1615 MacDonald clan commission that the James-Argyll patron-client relationship faltered. Argyll's dissatisfaction with James's recompense and recognition of duties performed, coupled with Cornwallis's religious influences, aided in creating a breach between them, the responsibility of which lay with James. This breach revealed a characteristic of James's personal monarchy: displeasure towards open profession of Catholicism which he interpreted as defiance to his authority. The king's lack of response and seeming failure to participate in the Argyll-Cornwallis marriage signalled his uncertainty and wariness over the union and perhaps a waning trust in Argyll. James's stance was likely based on disapproval of Cornwallis's overt Catholicism and on the realisation that Argyll alone could command and conquer large swaths of Scotland. But once Argyll left for the continent, even though he served the king of Spain, he was no longer a threat to James or his kingdoms. Argyll's speedy rehabilitation, like Huntly's, showed that the earl's status as a powerful magnate in Scotland, rather than his religion, was of much greater interest and value to the king.

\section{Conclusion}

The judges' findings in the 1568 Case of the Mines presciently described one year prior to the Northern Rebellion what were likely the crown's misgivings regarding increasing the wealth and power of certain subjects, i.e., Catholics of questionable loyalty. The judges believed that the northern, Catholic earl of Northumberland:

169 John Willock, The Great Marquess: Life and Times of Archibald, $8^{\text {th }}$ Earl, and 1 ${ }^{\text {st }}$ (and Only) Marquess of Argyll (16071661) (Edinburgh and London: Oliphant Anderson \& Ferrier, 1903), 10.

$170 \mathrm{JPC}, 18$. 
would surpass the king in treasure and substance, which would make the subject honourable and powerful, and the king contemptible, and liable to be deposed or rebelled against: For a subject who is superior to the king in substance and treasure will seldom obey, and for the servant to be greater than the master, or the subject greater than the king, is very disproportionable, and subversive of all order and rule. ${ }^{171}$

The Mines Case ruling emphasised the importance of social hierarchy and the monarch's predominance in terms of power, prestige, and "treasure": elements manifest in the Westmorland-Howard, Norfolk-Leybourne, and Argyll-Cornwallis marriages. The above examples have exposed Elizabeth's and James's initial hesitation in dealing with the power and influence of the upper-level nobility and their lack of trust of those individuals, especially those who maintained Catholic traditions. Remaining silent and indirectly resisting their marriages likely reflected a desire not to alienate those peers entirely. Norfolk, Westmorland, Strange, and Argyll were desirable figures in terms of the service they could provide the crown. But they were ultimately deemed untrustworthy because their marital alliances had the potential to destabilise the monarchy.

Elizabeth's and James's non-participation in certain marriages of prominent nobles appears to be a purposeful strategy which utilised the silence of the royal prerogative, emphasised the asymmetrical nature of hierarchy, and underlined the importance of trust. In analysing the marital alliances presented in this chapter, many reasons have been provided for the lack of detail in the historical record and for why Elizabeth or James might have absented themselves from involvement. These reasons vary first from an uncertainty over the long-term outcome of the alliances of families, indecision over the couple's loyalty to their monarch, or, finally, to a desire to leave some interdenominational marriages publicly unrecognised. Mirroring Farrell's research, each reason suggests the power differential between monarch and noble which altered the level of trust. And, returning to Trouillot's work, Elizabeth's or James's dominance and ultimate triumph over the noble couples may account for the silence of the historical record, particularly since they distrusted the weddings. It is understandable that there existed a level of distrust and latent fear between the monarch and those nobles

171 Plowden, Commentaries, vol. 1, 316. 
who had a claim to the throne or whose allegiance to the crown and religious affiliation were suspected. When Elizabeth and James responded with reticence to problematic marriages they did so as a self-protective measure. The silence of the royal prerogative sustained a sense of limbo until noble loyalties and intentions could be confirmed. It also quietly marginalised powerful noblemen when their direct punishment might have been detrimental to the monarch's authority. As a result, this chapter corresponds with examples in chapter three, specifically the Oxford-Cecil, Cumberland-Russell, and Wharton-Clifford marriages. Though these unions were supported by the queen, because the noblemen had Catholic ties they were denied any substantive government office-they were effectively excluded.

This chapter has shown that Elizabeth's and James's non-participation, assisted by the silence of the royal prerogative, was regularly associated with the open practice of Catholicism. Their lack of public involvement in Catholic-related unions has left the historical record empty, even though their awareness of those marriages was virtually certain. They retreated from Westmorland's, Leybourne's, Spencer's, and Cornwallis's known staunch Catholicism, responding with silence. The lateral connections forged between families through marriage might potentially serve a religion at odds with Protestantism and, therefore, the state. Suspicion of Catholics was a characteristic of both monarchs' regimes, the perception being that the practice of the Roman religion was synonymous with disloyalty to the crown. Indeed, Elton has expressed that in England after the Northern Rebellion "Obedience to Rome... now meant acceptance of the excommunication and deposition of Elizabeth, and therefore... treason."172

In the 1550s and 1560s Elizabeth did face numerous religious-based threats to her person and kingdom: incarceration and potential execution for her alleged involvement in the Wyatt Rebellion, conflict with Catholic France, the religious wars in the Netherlands, and Catholic plotting against her. Alford's research into the early Elizabethan succession question has highlighted the nature of the queen's first full decade on the throne. According to Alford, in the wake of these dangers Elizabeth assumed what was an ineffective "silent indecision." 173 Wallace MacCaffrey's assessment of the 1560s concluded the same: "when it came to the

172 Elton, ed., 420.

173 Alford, 159. 
making of irreversible decisions she had trembled indecisively," which revealed "more than a touch of unsureness."174 Doran has echoed this idea when discussing Elizabeth's own dynastic marriage negotiations suggesting that the queen had "an emotional block to any kind of change or an almost pathological inability to take a decision." 175 The Westmorland-Howard and Norfolk-Leybourne marriages support these historians' views on Elizabeth's indecision in that they reveal her generally ineffective management of interdenominational weddings of the $1560 \mathrm{~s}$ and her inability to connect with Catholic or Catholic-sympathising peers.

However, Elizabeth handled the Norfolk-Audley marriage and HerbertTalbot double wedding differently. Probably because these unions were Protestant and the loyalty of all parties was accepted, Elizabeth did not intervene though she showed support later. Technically-speaking, she possessed no right to intervene in the Herbert and Talbot weddings and the Arundel-Dacre and StrangeSpencer marriages. Notably though, each of these alliances involved upper-level noblemen. In the case of Lord Strange, his close proximity to the throne, Catholic sphere of influence, and choice of a wealthy Catholic wife were marks against him which likely contributed to the queen's lack of recognition.

In a similar way, James's non-participation in the Argyll-Cornwallis marriage signalled a level of disapproval based on two factors: Catholicism and an awareness of Argyll's power which the king desired to restrain and bring under his influence. James's initial response to Argyll's marriage to a known, practicing Catholic was similar to Elizabeth's reaction to the Westmorland-Howard, NorfolkLeybourne, and Strange-Spencer marriages: he did not participate or acknowledge it. Like Elizabeth's response to the Norfolk-Audley union, James communicated approval of the Argyll-Cornwallis marriage at a later date. Albeit, his absence from the christening of the Argylls' first child, with Prince Henry standing as his proxy, indicated that the king, for a second time, did not wish to recognise personally the union of the Campbell and Cornwallis families. Nor did the king intend to offer any patronage to the couple, suggesting that he sought to relegate them to some degree from royal favour. James's lack of immediate involvement probably stemmed from fear and prudence, which supports Larson's analysis that a lack of trust "is often

174 MacCaffrey, Shaping of the Elizabethan Regime, 87.

175 Doran, Monarchy, 4. 
prudent," and that although "Distrust and fear are not the same... they are often conflated."176 As mentioned, 1609 was tense with the pursuit of recusants. Public royal support of an upper-level peer's marriage to a Catholic would have been illadvised. It should be remembered as well that though James generally placed loyalty to the crown above subjects' religious preferences, suggesting that he was more tolerant than Elizabeth, he still required conversions to Protestantism as in the Huntly-Stewart, Mar-Stewart, and Buckingham-Manners marriages.

Chapter three examined supportive crown involvement and the importance to royal authority and kingdom stability of establishing monarch-noble patronage at marriages, but this chapter has shown that, in the end, non-participation was also a distinct and an effective management strategy. Monarchical silence was likely an attempt at preventing ill-will from erupting into openly divisive relations with the nobility who formed questionable lateral connections in a hierarchical system. Yet non-participation prevented meaningful connections, fostered a sense of exclusion and detachment, and created an underlying conflict which manifested itself in division at a later date, as in the Westmorland-Howard and ArgyllCornwallis marriages. Nevertheless, despite the failure to initiate critical patronage ties with the nobility, the crown still prevailed, supremacy was maintained, and the royal prerogative figured greatly in the process.

176 Larson, 38. 


\section{Chapter 5}

\section{Nemo me impune lacessit: \\ monarchical opposition to noble marriages ${ }^{1}$}

Around 1590 royal ward Henry Wriothesley, third earl of Southampton, defied his guardian, Burghley, by rejecting the ward's marriage proposed for him. Burghley had organised a suitable match for the young earl to his granddaughter, Lady Elizabeth de Vere, daughter of Edward, seventeenth earl of Oxford. ${ }^{2}$ As scion of a staunchly Catholic family, Southampton's union with Lady Elizabeth would have allied him to the equally staunchly Protestant Cecils and shaped him to the reformed religion. ${ }^{3}$ Although there is no evidence of Queen Elizabeth's involvement, it is likely that she approved of Burghley's arrangement of this interdenominational marriage. But, by refusing his guardian's choice of bride, Southampton not only allegedly faced a ruinous $£ 5,000$ fine, the "value" of his ward's marriage-a saleable commodity-he also angered Burghley with his rebuff. 4

In 1595 Southampton, having now reached his majority, was at court in an attempt to win Elizabeth's favour despite the previous disgrace over his ward's marriage. A follower of royal favourite Robert, earl of Essex, Southampton developed an acquaintance with Essex's cousin Elizabeth Vernon, a maid of honour to the queen. The earl's close association with Vernon was noted at the time,

My Lord of Southampton doth with too much familiarity court the fair Mrs. Vernon, while his friends, observing the Queen's humours toward my Lord of Essex, do what they can to bring her to favour him, but it is yet in vain. ${ }^{5}$

\footnotetext{
1 The motto of Scotland, "No one provokes me with impunity."

${ }^{2}$ Henry Foley, ed., Records of the English Province of the Society of Jesus, vol. 4 (London: Burns and Oates, 1878), 49; Hurstfield, Queen's Wards, 249, 142, 144, 251; Charlotte Carmichael Stopes, The Life of Henry, Third Earl of Southampton, Shakespeare's Patron (Cambridge: Cambridge University Press, 1922), 34-35, 65.

3 Both Southampton's parents were Catholic. See FSL, Cavendish-Talbot MSS, L.b.338; Foley, ed., vol. 3, 659; ODNB, s.v. "Wriothesley, Henry, third earl of Southampton."

4 Foley, ed., vol. 4, 49; Hurstfield, Queen's Wards, 251; ODNB, s.v. "Wriothesley, Henry, third earl of Southampton."

5 CP, Vol. 168/8; Sidney Papers, vol. 1, 348; Stopes, 35; Kinney, ed., 35, 125.
} 
In 1598, Southampton joined an embassy to Paris, but, while away, he was informed that Vernon was pregnant. The earl quickly, and secretly, returned to London to wed Vernon and departed again for France. The couple's hurried and clandestine marriage became exposed when Vernon's pregnancy could no longer be concealed. ${ }^{6}$ The queen was "grievously offended" by the discoveries. Acting in loco parentis for Vernon, Elizabeth had a responsibility to manage her maid of honour's marriage prospects and negotiations. Instead, by becoming intimate with the queen's maid and marrying "without her [the queen's] privity [counsel]," Southampton circumvented Elizabeth's monarchical authority and duty, appropriating them for himself.7 His and Vernon's audacity met with immediate censure as both were imprisoned in the Fleet. ${ }^{8}$ After a brief incarceration the couple was released, but they never returned to Elizabeth's favour. Southampton's Catholic connections and previous defiance of his guardian likely did not help his case. And, though an upper-level nobleman, the earl's political value was weak; he simply "was not important enough for the queen to forgive."

As demonstrated in the Southampton-Vernon marital alliance, this chapter examines noble marriages to which Elizabeth and James were opposed. Opposition revealed that the monarch deemed the union a threat to his or her position, to the kingdom as a whole, or to his or her reputation, as in the cases of secret marriages of royal household members. These weddings, which frequently established potentially dangerous lateral connections within the hierarchy, often resulted in punitive measures like temporary imprisonment, permanent banishment from court, or long-term house arrest; all of which caused isolation from the monarch, the source of patronage. Whether light or severe, punishment upheld authority because it acted to separate offenders from the favour and wealth of the court and to diminish the possibility of their garnering support that might become threatening to the monarch.

In many cases the marital unions to which the monarchs objected were also clandestine or secret. Clandestine marriages were "those that failed to conform to

\footnotetext{
${ }^{6}$ Chamberlain, vol. 1, 44; Cokayne, ed., vol. 12/1, 129, 130n.

7 TNA, SP $12 / 268 / 76$.

8 Ibid, SP 12/268/186; ODNB, s.v. "Wriothesley, Henry, third earl of Southampton."

${ }^{9}$ Rickman, 34. See also Pearson, 110.
} 
the requirements of canon law as to place, time and procedure."10 "Private" marriages also belonged to the clandestine category in that they were unlicensed and, therefore, did not meet canonical prerequisites. ${ }^{11}$ When most marriages were "normally arranged by parents and relations, and discussed for months beforehand," the clandestine marriage differed from the typical "highly public event, performed after banns or licence, in the parish church."12 This chapter does not discuss specifics of the wedding ceremonies, partly because verbal agreement in the present tense was the only condition for a legally binding marriage in the early modern period. ${ }^{13}$ Wall has observed that "Even though a contract marriage was legal, it could be hard to prove."14 Indeed, clandestine marriages could be determined valid while canonically-sound, public marriages could be annulled. ${ }^{15}$ Still, the nobility customarily wished to ensure that their marriages were openly conducted and validated by canon law for the safeguarding of their patrimony. Immediate and wider kin groups, retainers, and tenants, were dependent upon the patronage and financial aspects which followed the formalised union of families through marriage.16 The legality of the marriage was, therefore, vital for the success and sustenance of many which is why noblemen frequently had their marriages validated by parliamentary statute. ${ }^{17}$ As a result, clandestine marriages among the nobility were rare, contrary to historian Johanna Rickman's assertion (Table 5.1).18

The central focus of this chapter is those clandestine noble marriages which were challenged by Elizabeth and James because they appeared to have been deliberately conducted without their knowledge to circumvent their authority over the unions. What follows are descriptions of five Elizabethan and Jacobean clandestine noble marriages and how the monarch reacted to the specific circumstances created by each. It is true that Elizabeth and James did not

${ }_{10}$ R. B. Outhwaite, Clandestine Marriage in England, 1500-1850 (London: Hambledon Press, 1995), xiv.

11 Nadine Akkerman, Invisible Agents: Women and Espionage in Seventeenth-Century Britain (Oxford: Oxford University Press, 2018), 28

12 Wall, "For Love, Money, or Politics?," 514.

13 Carlson, 22; Rickman, 16.

14 Wall, "For Love, Money, or Politics?," 532.

15 For example, the1598 Southampton-Vernon clandestine marriage was valid while the 1606 Essex-Howard marriage though legitimate and publicly conducted in James's presence was later annulled.

16 Brown, Noble Society, 134.

17 Elton, Parliament, 312.

18 Rickman, 5. Citing Elizabeth's personal or political opposition to the marriages of some maids of honour and the societal expectation that women should marry, Rickman states that "secret marriages were thus fairly common among the court nobility." 
necessarily have a clear right, or even a need, to take part in every noble marriage. But they did possess the power of the royal prerogative, prerogative courts, and as supreme governor of the church to enact any punishment they desired against marriages they opposed. Their authority rested mainly in the marriages of royal wards and over members of their household, unmarried and widowed, for whom they acted in loco parentis. When couples decided to appropriate for themselves the monarch's rights and married clandestinely they risked punishment and, more importantly, separation from royal support. Moreover, unsanctioned successionrelated weddings that could affect the power and position of the sitting monarch repeatedly provoked crown resistance. As will be demonstrated, major consequences were often imposed on those subjects with royal blood and succession rights who dared to wed in secret.

That said, secret weddings did not always result in royal opposition or significant, lasting condemnation; monarchical responses were situational. Sometimes Elizabeth or James had no justification to intervene, as mentioned; the transgressing couple had little political following, negating the need for interference; or because the couple's loyalty was completely unquestioned. For instance, it does not appear that Elizabeth acknowledged the 1577 Bath-Cornwallis clandestine marriage. Though a royal ward, Bath's wardship had passed to his mother ${ }^{19}$ who, rather than the queen, retained the right to approve his marriage. ${ }^{20}$ Only twenty-years-old, Bath had no political following and although his unsanctioned and unequal marriage was to a staunchly Catholic gentlewoman, his mother moved quickly to have it annulled. ${ }^{21}$ In 1578 the earl of Leicester married Elizabeth's cousin Lettice Knollys, the widowed countess of Essex, without the queen's knowledge, inciting her fury. ${ }^{22}$ Though the earl ultimately preserved his close bond with the queen, he was temporarily banished to his estates. His new countess did not fare so well-she was barred from the court and royal favour. ${ }^{23}$ In 1581, Lord Beauchamp, "illegitimate" son of Edward Seymour, first earl of Hertford, and Lady Katherine Grey, claimant to the throne, secretly wed Honora Rogers. Still a minor, Beauchamp's marriage had not been sanctioned by his father

\footnotetext{
19 ODNB, s.v. "Bourchier, William, third earl of Bath."

${ }^{20}$ Hurstfield, Queen's Wards, 137.

21 Weikel, 16, 21-22; HMC, Salisbury, vol. 11, 223; ibid, Fifth Report (London: H. M. Stationery Office, 1876), 138.

22 Nichols, Elizabeth, vol. 2, 223; Whitelock, 168; Cokayne, ed., vol. 7, 551; ODNB, s.v. "Dudley, Robert, earl of Leicester."

23 Whitelock, 178; Rickman, 57; ODNB, s.v. "Dudley, Lettice, countess of Essex and countess of Leicester."
} 
who, in response, severed contact between the couple. The young lord begged the queen's intercession so that he might cohabit with his wife. Acting as judge, the queen responded with support knowing that, apart from his illegitimacy, in contracting a disparaging marriage Beauchamp ensured that he would be unfit to sit upon the throne. ${ }^{24}$ Royal favourite Robert Devereux, second earl of Essex, clandestinely married the widowed Frances Walsingham in 1587. His audacity resulted in only a temporary banning from court as "Elizabeth's anger soon cooled."25 The queen was not involved in the 1601 Hertford-Howard clandestine marriage. She apparently considered it innocuous since the earl had been "Rehabilitated," forgiven for his past transgressions and his distant claim to the throne described below. As he was uninterested in the throne for himself, Elizabeth had no reason nor vested right to intercede in the 62-year-old earl's third marriage. ${ }^{26}$ In 1621, James's cousin Ludovick Stuart, second duke of Lennox's third marriage to Hertford's widow, Frances Howard, was conducted surreptitiously. ${ }^{27}$ No punishment followed because Lennox's loyalty was undisputed. These clandestine marriage cases represent a range of responses from complete lack of punishment and non-participation to long- and short-term exile and open support. They exhibit the crown's flexibility towards those secret unions which were ultimately deemed non-threatening to the crown.

Historians have commented upon the number of clandestine marriages that took place among Elizabeth's household staff, provoking the queen's fury and undermining her authority and reputation. ${ }^{28}$ James also condemned secret weddings and expressed disapproval over certain planned unions during his reign. $^{29}$ Likewise, on the continent, Philip II of Spain punished members of his nobility for engaging in illicit marriages. ${ }^{30}$ Clandestine noble marriages were necessarily viewed as overt displays of defiance and denials of respect for and

${ }^{24}$ HMC, Bath, vol. 4, xvi, 155-156, 159-160, 190-193; TNA, SP 12/154/77; ibid, SP 12/155/95. See also CSPD, Addenda, 1580-1625, 406; Doran, Circle, 60-61; ODNB, s.v. "Seymour, Edward, first earl of Hertford."

25 ODNB, s.v. "Devereux, Frances, countess of Essex and of Clanricarde;" ibid, s.v. "Devereux, Robert, second earl of Essex."

26 HMC, Bath, vol. 4, xvii, 161-162.

27 Chamberlain, vol. 2, 375-376; Paul, ed., vol. 5, 357.

28 For examples see Doran, Circle, 206-214; Rickman, 36-37; Hammer, "Sex and the Virgin Queen," 77-97; Stone, Crisis, 605-606, 609.

29 Brown, Noble Society, 121, 123.

30 Henry Kamen, Philip of Spain (New Haven: Yale University Press, 1997), 173-174; Hammer, "Sex and the Virgin Queen," 82. 
responsibility to the sovereign. ${ }^{31}$ As mentioned, Stone has reviewed noble marriage and family patterns in the sixteenth and seventeenth centuries, ${ }^{32}$ while Doran and Hammer have catalogued and assessed the impact of Elizabethan clandestine weddings and illicit relationships, noble and non-noble alike. ${ }^{33}$ Similarly, Johanna Rickman has looked at illicit sexual behaviour among nobility in early modern England. ${ }^{34}$ Doran has concluded that Elizabeth "particularly objected to... secret marriages, those where her permission in loco parentis had not been granted, and... the women involved had practised deceit." 35

While fully endorsing Doran's assessment, there is another crucial point that has gone unmentioned. A secretly conducted marriage deprived the monarch of key opportunities which an open, public marriage provided. These opportunities included, firstly, the chance to appear at the wedding in a lavish display of the royal person to bolster the divine nature and mystique of the crown among subjects, noble and non-noble alike. The royal presence gave visible approbation to the marriage pact, acting as a firm seal of approval. Secondly, the occasion allowed the monarch to acknowledge manifestly the couple and their respective families and ties which now bound them together in mutual benefit, monarch to nobility and reaffirmed the social hierarchy. This permitted Elizabeth and James to inaugurate what would hopefully become long-term, stabilizing and supportive monarch-noble patron-client relationships with the couples and, by extension, their families. Finally, by publicly acknowledging the newlyweds, the monarch theoretically gained the ability to transmit crown policies to nobles' spheres of influence as in the 1565 Warwick-Russell or 1588 Huntly-Stewart marriages illustrated in chapter three. Monarchical involvement in lawful and overt marriages supplied numerous possibilities for the exercise of authority and communication of agendas. In light of these significant and advantageous prospects fundamental to the strengthening their rule, it is easy to understand why Elizabeth or James became frustrated by secret marital alliances. Clandestine marriages dispossessed the crown of myriad opportunities for expanding power and influence. This has been a critical point overlooked by scholars.

\footnotetext{
31 Hammer, "Sex and the Virgin Queen," 82.

32 Stone, Crisis, 605-606, 609.

33 Doran, Circle, 206-214; Hammer, "Sex and the Virgin Queen," 80-97.

34 See Rickman, passim.

35 Doran, Circle, 207-208.
} 


\section{Database}

Clandestine weddings and other aristocratic marital unions which provoked monarchical opposition were uncommon. The database records a total of fifteen clandestine marriages from 1558 to 1625: eleven in Elizabeth's reign and four in James's (Table 5.1). The majority of perpetrators were aged twenty-two or younger, their inexperience and ardour perhaps overtaking their understanding of the consequences of their actions. Furthermore, in every case but one, the transgressors were upper-level nobility. This is significant. When the elite were willing to anger the monarch and jeopardise their own patrimony, it was not only alarming but it often correlated with a formidable monarchical response. Clandestine weddings and other alliances to which Elizabeth was opposed account for nearly $20 \%$ of all of her noble-marriage involvement. But, as described above, she did not dispute every unsanctioned match nor did she always heavily punish offenders. The queen objected to illicit weddings among household staff over whom she had an in loco parentis duty. She also strongly opposed secret marriages which might impact her succession plan, several of which are described below.

James infrequently displayed opposition to noble marriages. He contested at least five marriages, including the clandestine Lennox-Ruthven and SeymourStuart marriages discussed below. On occasion James also protested prearranged marriages like that of the earl of Argyll to Lady Anne Douglas, the earl of Cassillis to Lady Anne Campbell, the master of Orkney to the youngest daughter of the sixth earl of Morton, and Huntly to Anne Ker mentioned in chapter three. ${ }^{36}$ During his English reign he initially supported the 1606 Essex-Howard marriage discussed in chapter three but then later opposed it, seeking its termination in support of Lady Frances's subsequent marriage to his then-favourite, the earl of Somerset, described in the introduction. Overall, James had fewer clandestine weddings with which to contend because in Scotland, as Brown has noted, clandestine marriage or "elopement was rare, being regarded as abduction by the law."37 The database reflects this fact.

36 TNA, SP 52/47/119; ibid, SP 52/48/52; ibid, SP 52/47/15; ibid, SP 52/48/26. The Argyll-Douglas marriage took place on 24 July 1592 despite both Lady Anne's parents being against the match. See Brown, Noble Society, 121.

37 Brown, Noble Society, 121. 
Table 5.1: Clandestine noble marriages $(n=380)$ and monarchical opposition $(n=129)$

\begin{tabular}{lll|ll} 
& $\begin{array}{l}\text { Elizabeth I } \\
\text { Clandestine/ } \\
\text { Total Marriages }\end{array}$ & $\begin{array}{l}\text { Opposition/ } \\
\text { Total Involvement }\end{array}$ & $\begin{array}{l}\text { James VI/I } \\
\text { Clandestine/ } \\
\text { Total Marriages }\end{array}$ & $\begin{array}{l}\text { Opposition/ } \\
\text { Total Involvement }\end{array}$ \\
\hline $1558-1569$ & $2 / 41(5 \%)$ & $3 / 19(16 \%)$ & - & - \\
$1570-1579$ & $4 / 45(9 \%)$ & $3 / 19(16 \%)$ & - & - \\
$1580-1589$ & $3 / 37(8 \%)$ & $2 / 9(22 \%)$ & $0 / 15(0 \%)$ & $0 / 7(0 \%)$ \\
$1590-1599$ & $1 / 26(4 \%)$ & $1 / 7(14 \%)$ & $1 / 26(4 \%)$ & $2 / 13(15 \%)$ \\
$1600-1609$ & $1 / 13(8 \%)$ & $0 / 4(0 \%)$ & $0 / 68(0 \%)$ & $1 / 25(4 \%)$ \\
$1610-1619$ & - & - & $1 / 68(1 \%)$ & $1 / 13(8 \%)$ \\
$1620-1625$ & - & - & $2 / 41(5 \%)$ & $1 / 13(8 \%)$ \\
Totals & $\mathbf{1 1 / 1 6 2 ( 7 \% )}$ & $\mathbf{9 / 5 8 ( 1 6 \% )}$ & $\mathbf{4 / 2 1 8 ( 2 \% )}$ & $\mathbf{5 / 7 1 ( 7 \% )}$
\end{tabular}

The clandestine noble marriages described in this chapter showcase the importance of royal authority, court and kingdom stability, and succession. In all, five clandestine marriages occurring between 1558 and 1625 have been associated with the succession: four in Elizabeth's reign and one in James's. ${ }^{38}$ Since there were relatively few truly feasible claimants to the throne, monarchical opposition in the area of the succession was infrequently aroused. Nonetheless, these unions were sharply challenged because they were the most potentially destructive to monarchical power. The Seymour and Grey families figured repeatedly among the clandestine succession-related marriages. Furthermore, the Stuart family, with its connections to both the English and Scottish thrones, posed a threat during Elizabeth's reign as it would during James's.

Both Elizabeth and James considered the topic of succession as the sole remit of the monarch, a component of the royal prerogative. Due to Elizabeth's unmarried state and refusal to select an heir, the succession question was never answered during her reign. A level of uncertainty remained throughout the period which is probably why there were more succession-related marriages during her reign as opposed to James's. Under Elizabeth, all the marriages which might have had an impact on the succession had taken place by 1581, the year of the Beauchamp-Rogers union. This database finding supports recent Elizabethan succession research which suggests that Elizabeth had inwardly selected her successor by the late 1580s, though "the succession remained disputed" publicly.

38 The succession-related clandestine marriages were the 1560 Hertford-Grey, 1565 Keys-Grey, 1574 LennoxCavendish, 1581 Beauchamp-Rogers, and 1610 Seymour-Stuart. 
Doran and Kewes have conceded that though the succession question was outwardly "far from predictable... the Queen evidently favoured his [James's] candidacy" and she engaged in "practical measures to aid James's eventual takeover and weaken the position of his leading competitors."39 Janel Mueller's research has supported the claim that Elizabeth had chosen James as her successor by the 1580 s, citing a letter that the queen wrote to him in March 1586:

Touching an instrument [for Elizabeth's proffered financial assistance and possibly rights to the crown] that you desire to have me sign... Who should doubt performance of a king's [Elizabeth's] offer... I will, as long as you with evil desert alter not your course, take care for your safety, help your need, and shun all acts that may damnify you in any sort either in present or future time. And for the portion of relief, I mind never to lessen, though as I see cause I will rather augment. And this I hope may stand you in as much assurance as my name in parchment. ${ }^{40}$

Mueller has asserted that this epistle "is tantamount to a royal charter, a testamentary writ empowering him as her successor." ${ }^{41}$ Additionally, Hammer has asserted that Mary, queen of Scots's execution in 1587 left “James VI of Scotland the most obvious to her claim and Elizabeth consistently treated him as her protégé, although she adamantly refused to confirm him as her chosen heir." 42 The work of Doran, Kewes, Mueller, and Hammer supports the absence of successionlinked marriages in the database after 1581.

Among the clandestine noble marriages in which James voiced objection, only one has been linked directly to the succession, the Seymour-Stuart marriage of 1610. This marriage, described below, occurred before the death of Prince Henry in 1612 while James was on the English throne and had two living male heirs. The succession was not the same issue during James's reign as it was in Elizabeth's which is evidenced by the single example identified in the database. James ascended the Scottish throne in 1567 due to his mother Mary, queen of Scots's abdication. If the young king had passed away during his minority, her return to the throne was a possibility. Nonetheless, James's 1590 marriage to Anne of Denmark secured the pathway for a stable succession. Between Mary, queen of Scots's execution in 1587 and the birth of Prince Henry in 1594, John Hamilton,

\footnotetext{
39 Doran and Kewes, eds., 20, 4, 5.

40 ECW, 275.

41 Mueller, 1067.

42 Hammer, "Royal Marriage," 67.
} 
later first marquess of Hamilton, was deemed heir to the Scottish throne after James. ${ }^{43}$ While Rosalind Marshall has indicated that James "did not view him [Hamilton] with suspicion and the two men were close friends," Jamie Reid-Baxter has suggested otherwise: "James had been brought up to dislike" the Hamiltons, who did not have a connection to the English throne. ${ }^{44}$ Reid-Baxter has stated that by the early 1590s attempts were being made to name Lennox as successor, rather than Hamilton, because the former had connections to both the English and Scottish crowns. ${ }^{45}$ Nevertheless, the arrival of Prince Henry launched James's own distinct line of succession. And, by the time James became king of England in 1603 he had two male heirs and one female. The succession for the unified crowns of England and Scotland was well-established and without question.

\section{Elizabethan case studies}

\section{Hertford-Grey, 1560}

When the Arran-Grey proposed marriage described in chapter two foundered, Lady Katherine Grey and Edward Seymour, first earl of Hertford, were both at court. ${ }^{46}$ Despite Elizabeth's Anglo-Scottish matchmaking attempt, they had already established a romantic bond, one which had formed during Mary I's reign. After the execution of her father and sister in 1554, Lady Katherine became a royal ward under the guardianship of Hertford's mother, Anne Seymour, dowager duchess of Somerset. ${ }^{47}$ Anne of Somerset was descended from King Edward III, which also gave Hertford a distant claim to the throne. Though Lady Katherine had enjoyed a good relationship with Mary I, Elizabeth's treatment of her cousin and heir was more aloof, most likely due to Lady Katherine's chief position in the succession.48 Before Elizabeth's coronation in January 1559, Lady Katherine was ousted from her position in the bedchamber and demoted to the privy chamber. A

\footnotetext{
43 CSPSC, 1593-1595, 408.

44 ODNB, s.v. "Hamilton, John, first marquess of Hamilton;" Jamie Reid-Baxter, "Politics, Passion and Poetry in the Circle of James VI: John Burel and His Surviving Works," in A Palace in the Wild: Essays on Vernacular Culture and Humanism in Late-Medieval and Renaissance Scotland, ed. L. A. J. R. Houwen, A. A. MacDonald, and S. L. Mapstone (Leuven: Peeters, 2000), 211.

45 Reid-Baxter, $211 \mathrm{n}$.

${ }^{46}$ CPR, 1558-1560, 58. Hertford was the son of Protestant champion Edward Seymour, duke of Somerset and lord protector under Edward VI. Somerset was executed in 1552. See ODNB, s.v. "Seymour, Edward, duke of Somerset [known as Protector Somerset]."

${ }^{47}$ Lady Katherine Grey's father, Henry Grey, marquess of Dorset, and her sister Lady Jane Grey were executed for their alleged parts in the Wyatt Rebellion. See Chapman, 174.

48 Doran, Circle, 46.
} 
letter from Spanish ambassador Gómez Suárez de Figueroa, Count de Feria, to Philip II confirmed that Grey was "dissatisfied and offended at this [that the Queen did not wish her to succeed], and at the Queen's only making her one of the ladies of the presence, whereas she was in the privy-chamber of the late Queen [Mary I], who showed her much favour." 49 Moreover, during the coronation celebrations Lady Katherine was relegated to a seat in the line of chariots rather than riding on horseback directly behind Elizabeth as one of the ladies of the court and as heir apparent based on Henry VIII's will and the 1544 Succession Act.50 On this very public occasion, Lady Katherine had been denied recognition of her rank and legal status. What can be understood from Spanish dispatches is that Lady Katherine desired Elizabeth's acknowledgment of her position as rightful heir, but the queen's initial response was exclusion. Although Lady Katherine re-joined the queen's bedchamber staff in early 1560, Elizabeth's earlier detached behaviour and the lack of trust between the two women likely contributed to her cousin's decision to take her marriage into her own hands. ${ }^{51}$

In what may have been a pre-emptive strike to prevent betrothal to another suitor of the queen's choosing, Lady Katherine and Hertford were secretly married by a priest at Hertford's house in Canon Row, London, sometime between late November and Christmas $1560 .^{52}$ Lady Jane Seymour, Hertford's sister, was the only witness. ${ }^{53}$ It is possible that upon hearing the news of François II's death, Hertford and Lady Katherine may have felt encouraged to move forward with their plans to marry, aware that Arran's own marital interests were shifting to Mary, queen of Scots. ${ }^{54}$ As Elizabeth's marriage to Prince Eric of Sweden, Charles, archduke of Austria, or another seemed probable, neither focussed on the

\footnotetext{
${ }^{49}$ CSPSp, 1558-1567, 45.

50 Leanda de Lisle, The Sisters Who Would be Queen (London: Harper Press, 2008), 181; SR, vol. 3, 955-958: 35 Hen. VIII, 1543-1544, c. 1; Elton, ed., 3.

51 Whitelock, 14.

52 Mortimer Levine suggested that the marriage took place after 20 November 1560 which would have marked the one year anniversary of the death of Katherine's mother, Frances of Suffolk, and, thus, the end of her mourning period. See Levine, 19-20. See also Goldring, Eales, Clarke, and Archer, eds., vol. 1, 168. Goldring et al. cite Frances of Suffolk's death as 21 November 1559.

53 HMC, Salisbury, vol. 13, 61-62; Kinney, ed., 33. Jane Seymour served as a maid of honour to Elizabeth from 1558 until her death in 1561.

${ }^{54} \mathrm{CSPF}, 1560-1561,492$
} 
ramifications their wedding might have on the queen's position or the succession..$^{55}$

While Lady Katherine and Hertford may not have believed that their marriage would be deemed threatening, they had been advised by Anne of Somerset and Burghley of the anger their union might provoke. ${ }^{56}$ When they married without permission, Elizabeth's in loco parentis responsibility to arrange and approve an advantageous marriage had been removed. But, more than that, Lady Katherine's position as heir presumptive meant that royal approval for her marriage, though no longer a legal necessity, was an essential sign of respect for and obedience to the crown. In addition, as the Arran-Grey proposed marriage revealed, Elizabeth was fully prepared to assume her in loco parentis right and to use the royal prerogative to manage Lady Katherine's marriage to benefit the crown. Despite the failure of the Arran-Grey proposed marriage, Elizabeth likely would have attempted to locate another pro-monarch spouse for Lady Katherine and to establish a patron-client relationship. A marriage with Elizabeth's backing would have aided the crown and removed the pressure Lady Katherine's presence put on the succession. Prospective spouses might have been, like Arran, Elizabeth's own suitors: Eric of Sweden or Charles, archduke of Austria, through which Grey could be used as a link between England and a continental ally. ${ }^{57}$ Furthermore, had Elizabeth successfully matched her cousin to a foreign husband, it would have physically removed her heir presumptive from the realm, reducing Lady Katherine's ability to develop a strong following to rival the queen's.

Elizabeth became aware of the Hertford-Grey clandestine marriage in August 1561 when Lady Katherine's pregnancy could no longer be concealed. ${ }^{58}$ Burghley recorded that “The Queen's Majesty thinketh, and so do others with her, that some greater drift was in this; but for my part I can find none such."59 Nevertheless, Elizabeth took steps to eliminate the threats that the wedding and forthcoming child posed. By 26 August, Lady Katherine was in the Tower and

55 Ibid, 1561-1562, 41. The King of France understood that "the matter between the Queen of England and the King of Sweden is at a point."

56 Leanda de Lisle, "Katherine Grey: Heir to Elizabeth," History Today 59 (2009): 23; Chapman, 174, 183-184, 186-187; Doran, Circle, 48.

57 CSPSp 1558-1567, 114, 176. Quadra believed that "the Archduke might be summoned to marry Lady Catherine."

58 CP, Vol. 153/87.

59 Philip Yorke, Earl of Hardwick, ed., Miscellaneous State Papers: From 1501-1726, vol. 1 (London: Strahan \& T. Cadell, 1778), 177. See also CSPSp, 1558-1567, 216. 
Hertford was recalled from Europe to face imprisonment. ${ }^{60}$ Their child Edward was born in the Tower on 24 September 1561 to avoid "Katherine and her baby from being seized and used as the centre of a revolt." 61

Several months later, Elizabeth employed the royal prerogative when she convened the High Commission, the highest level ecclesiastical court which was under the sole jurisdiction of the monarch. ${ }^{62}$ In composing the letters patent to call the commission, Elizabeth expressed her desire to have the Hertfords' son "declared a bastard by Parliament."63 With its authority also backed by statute, High Commission findings were enforceable. ${ }^{64}$ Crucially, because it was headed by those who owed their appointments to the monarch, the High Commission had the crown's guiding hand behind it. ${ }^{65}$ The Hertford-Grey case was examined by Matthew Parker, archbishop of Canterbury, Edmund Grindall, bishop of London, and others who were tasked with establishing the validity of the marriage. ${ }^{66}$ The baby Edward Seymour's status as Elizabeth's heir after Lady Katherine, according to Henry VIII's will, hinged upon the verdict. ${ }^{67}$ Yet the queen's suspicion and desire for a verdict against the Hertfords was apparent even before the High Commission convocation. Quadra reported from London that "The Queen claims that the marriage is not to be considered valid as there was no witness," while talk in Europe was that "the Queen is taking steps to have My lady Catherine's son declared a bastard by Parliament."68 Elizabeth wrote to Sir Edward Warner, lieutenant of the Tower, informing him of the commission's inquiry while also prejudging its outcome as she described the "infamous Conversation, and

60 Calendar of the Clarendon State Papers, ed. O. Ogle, W. H. Bliss, and H. O. Coke, vol. 1 (Oxford: Clarendon Press, 1872), 478 [hereafter Clarendon Papers].

${ }^{61}$ Norman L. Jones, The Birth of the Elizabethan Age: England in the 1560s, Paperback ed. (Oxford and Cambridge, Mass.: B. Blackwell, 1995), 105.

62 CSPD, 1547-1580, 194; Roland G. Usher, The Rise and Fall of the High Commission (1913; reprint with an introduction by Philip Tyler, Oxford: Clarendon Press, 1968), 49-50; Rosemary O'Day and Felicity Heal, eds., Continuity and Change: Personnel and Administration of the Church of England 1500-1642 (Leicester: Leicester University Press, 1976), 250; Elton, ed., 223.

${ }^{63}$ Quoted in Whitelock, 58.

${ }^{64} S R$, vol. 4, 352: 1 Eliz. I, 1559, c. 1; O’Day and Heal, eds., 250.

$65 S R$, vol. 4, 352.

66 Parker had been made aware of the Hertford-Grey marriage in August 1561. See Matthew Parker, Correspondence of Matthew Parker, D.D., Archbishop of Canterbury, ed. John Bruce and Thomas Perowne (Cambridge: Cambridge University Press, 1853), 148-149.

${ }^{67}$ Jones, Elizabethan Age, 105. In 1562 Elizabeth convened the High Commission to determine the legitimacy of another noble marriage, that of Henry Neville, fifth earl of Westmorland, to Margaret Cholmeley, the sister of the earl's previous wife. See CPR, 1560-1563, 336; CSPD, 1547-1580, 185.

68 CSPSp, 1558-1567, 216; CSPR, 1558-1571, 52. 
pretended Marriage betwixt the Lady Katherine Grey, and the Earl of Hertford." 69 It was Warner's lenient treatment which resulted in the birth of the Hertfords' second son, Thomas, in February 1563 which further incensed the queen.

Though Burghley had not viewed their wedding in a menacing light, others saw the solidly Protestant Hertford-Grey union and its offspring in stark contrast to Elizabeth's lack of marriage and planned succession. As Doran has commented, the threat of Lady Katherine's marriage "stemmed from her influence on the succession debate," because it had the potential to disrupt Elizabeth's plan to support the claim of Mary, queen of Scots. ${ }^{70}$ Similarly, Simon Adams has noted, "There is no evidence that she [Elizabeth] ever regarded anyone other than Mary [queen of Scots] as her successor... she never showed any sympathy for the rival claim of Lady Katherine Grey."71 But many at court, in government, and abroad supported Lady Katherine's claim as heir, even more so with the birth of her son and the promise of a "masculine succession."72 The Spanish ambassador himself preferred to see Lady Katherine as queen of England. ${ }^{73}$ In late 1559 there had been a Spanish plot "to practice the conveying out of the realm the L.K. [Lady Katherine Grey]... to provide in marriage for her... the prince his [Philip's] son," thus securing Elizabeth's heir apparent and aligning her with Spain. ${ }^{74}$

This general inclination for the Suffolk line was manifested in other ways as well. In conjunction with Elizabeth's accession and the return to Protestantism, tracts and publications appeared which paid homage to the former "nine days' queen” Lady Jane Grey, Lady Katherine's sister, a Protestant martyr. ${ }^{75}$ Copies of Lady Jane's writings and her scaffold speech were published early in Elizabeth's reign. ${ }^{76}$ A Miles Coverdale treatise was re-released for the English market in 1560 and 1564 which contained a reproduction of Lady Jane's final letter to her sister Katherine, while John Foxe's Actes and Monuments, first appearing in 1563, included Lady Jane among the English victims for the reformed faith. ${ }^{77}$ These

${ }^{69} \mathrm{CP}$, Vol. 153/87; Levine, 22.

70 Doran, Circle, 63.

71 Simon Adams, "The Succession and Foreign Policy," History Today 53 (2003): 45.

72 Whitelock, 82, 58; CSPR, 1558-1571, 52; CSPSp, 1558-1567, 296.

73 CSPSp, 1558-1567, 45, 116.

74 Lettenhove, vol. 2, 25-26. See also CSPSp, 1558-1567, 114; CP, Vol. 201/133.

75 Eric Ives, Lady Jane Grey (Hoboken: John Wiley \& Sons, 2009), 2, 287. Lady Jane was queen for thirteen days.

76 Anonymous, The Lamentacion that Ladie Iane Made (London: [By J. Kingston] for Ihon Wight, 1562); Ives, 288.

77 Miles Coverdale, ed., Certain Most Godly, Fruitful, and Comfortable Letters (London: By Iohn Day, 1564), 662-663; Ives, 288; John Foxe, Actes and Monuments (London: John Day, 1563), 932-933. 
propagandist texts reminded the public of the Greys' commitment to Protestantism at a time when Elizabeth countered demands for greater reform to the Church of England..$^{78}$

Additionally, the previously-mentioned play Gorboduc, one of the earliest English tragedies, was presented to Elizabeth in January $1562 .{ }^{79}$ Some interpreted Gorboduc as an oblique call for the succession to be settled on the Suffolk line. 80 But Lady Katherine and her younger sister Lady Mary Grey were not the only possible heirs. In late 1561 English and Scottish ministers began planning a faceto-face meeting between Elizabeth and the Catholic Mary, queen of Scots. ${ }^{81}$ Mary, "descended of the blood of England," wished to ensure that she would not be "debarred" from her "right to that Crown."82 Still, in 1563 MP John Hales published a tract defending the Grey/Suffolk claim to the succession. In it Hales declared his

Judgement touching the right Heirs to the Crowne of England in Remainder and Reversion; which is, as I take it, presently the Lady Catherine, Daughter to the Lady Frances, both by King H. his Will, and also by the Common Lawes of this Realm; and that we be bound both by our Oaths and also by our Laws so to take her. 83

As Hales's tract fuelled the succession issue, highlighted by the Hertford-Grey marriage and Elizabeth's potential meeting with Mary, queen of Scots, another report from the period suggested that the general public favoured Hertford and Lady Katherine's cause:

There be abroad, both in the city and in sundry other places in the realm, broad speeches of the case of the Lady Catherine and the Earl of Hertford. Some of ignorance make such talks thereof as liketh them, not letting to say that they be man and wife. And why should man and wife be let from coming together? These speeches and others are very common. ${ }^{84}$

The pressure on Elizabeth increased when the 1563 Parliament demanded that she agree to marry or consider a successor, threatening to withhold funds until the question was settled satisfactorily. In the end, "a vote of supply to the Queen was

\footnotetext{
78 Elton, ed., 398.

79 Norton and Sackville, Gorboduc; Chambers, 80; James and Walker, 109.

80 James and Walker, 115-116.

81 CP, Vol. 201/139. Meeting plans were permanently halted on account of the St. Bartholomew's Day Massacre in Paris on 1 March 1562, which was led by Mary's uncle, François, duke of Guise. See Whitelock, 58.

82 CP, Vol. 147/17.

83 Hales, xli.

84 CP, Vol. 153/96; Levine, 28.
} 
unwillingly conceded, Parliament holding the succession to the crown should be first settled."85 Bearing these factors in mind, it is likely that the near-constant onslaught bombarding Elizabeth to marry or select a successor, heightened by numerous publications and parliamentary discussions strongly in support of Lady Katherine, played a part in the queen's decisive reaction to the Hertford-Grey clandestine marriage.

Following much questioning, protestations of innocence, and Hertford's and Lady Katherine's affirmations of the marriage's validity, the report of the High Commission inquiry was issued. Because the priest who performed the ceremony could not be found and Lady Jane Seymour, the only witness, was dead, the report declared "the marriage to have been unlawful" and the children became bastards by default, unable to inherit the throne. ${ }^{86}$ Hales disagreed with the commission's verdict. $^{87}$ Historians, too, have differed on whether the marriage could have been considered legitimate or not. Mortimer Levine has suggested that it could have been seen as a true and valid marriage that would simply need to be solemnised in a church. And, as members of the nobility, Hertford and Lady Katherine should have been afforded that opportunity. ${ }^{88}$ Norman Jones has stated that "a marriage without witnesses performed by a mystery priest gave the judges all the legal grounds they needed, but they must have been under intense political pressure to find against the child's legitimacy." 89 Doran, agreeing, has explained that the judges were left "with no legal grounds for overriding the queen's predetermined political decision" to repudiate the marriage. ${ }^{90}$

In a further extension of the royal prerogative, Hertford was ordered to appear before the Star Chamber, a court whose judges were members of the Privy Council. As such, they "reflected the King's will" as they "enforced the king's peace."91 There Hertford was fined a total of $£ 15,000$ : “£5,000 for deflowering the Lady Catherine, $£ 5,000$ for breaking out of his prison... $£ 5,000$ for iterating the said

85 Tomás Gonzalez, Documents from Simancas Relating to the Reign of Elizabeth, 1558-1568, trans. and ed. Spencer Hall (London: Chapman and Hall, 1865), 83-84.

86 HMC, Salisbury, vol. 1, 272; ibid, vol. 13, 61-62. Lady Jane Seymour died in March 1561.

${ }^{87} \mathrm{BL}$, Cotton MSS, Titus C/VII fol. 12

88 Levine, 27-28.

89 Jones, Elizabethan Age, 106.

90 Doran, Circle, 52.

${ }^{91}$ Lockyer, Britain, 6; Elton, ed., 165-166, 173. 
vicious act and imprisonment during the Q. [Queen's] pleasure." 92 This heavy financial burden in addition to the invalidation of the marriage and bastardisation of his two sons served as highly effective punishments. From Elizabeth's point of view, the finding of any other verdicts would have been unacceptable. Determinations of validity and non-guilt would have forced utterance of her own marriage and succession plans while confirming Lady Katherine's and her sons' positions as heirs to the throne. Ultimately, Elizabeth succeeded in terminating the Hertford-Grey marriage and its looming threat, burying it under a mound of illegitimacy and debt to the crown while effectively placing "every obstacle in the way of a Suffolk succession." By necessity, the queen would continue to back the commission's ruling for the remainder of her reign. ${ }^{93}$

\section{Keys-Grey, 1565}

On Elizabeth's orders, the earl and countess of Hertford and their sons were held in the Tower until August 1563 when plague in London forced their removal to separate locations. ${ }^{94}$ While the Hertfords were under prolonged house arrest, another clandestine wedding took place in London on 16 July 1565 between Lady Katherine's younger sister Lady Mary Grey, a maid of honour, and Thomas Keys, the queen's sergeant porter. ${ }^{95}$ Described as "deformed," Lady Mary, though of royal blood, never had the same following at court as her sister; she was not recognised as a plausible candidate for the throne. ${ }^{96}$ Moreover, she may have earnestly believed that by marrying beneath herself, Elizabeth would not perceive her as a threat. 97 To be sure, the inequality and disparagement of the Keys-Grey marriage guaranteed that Lady Mary would never be a true challenger for the crown. Notwithstanding any alleged defect, however, Lady Mary still possessed a royal lineage and her unsanctioned marriage forced Elizabeth to disregard any design she might have entertained to use her cousin and heir to her benefit. No

\footnotetext{
92 BL, Cotton MSS, Titus C/VII, fol. 12; HMC, Bath, vol. 4, 184.

93 Doran, Circle, 52, 60.

94 TNA, SP 12/29/124. Lady Katherine remained under house arrest until her death, being transferred to different guardians. See W. L. Rutton, "Lady Katharine Grey, and Edward Seymour, Earl of Hertford," EHR 13 (1898): 303-305.

95 Merton, 86, 261; Kinney, ed., 27. The secret marriage was quietly arranged to coincide with the wedding of the queen's cousin Henry Knollys to Margaret Cave, daughter of Sir Ambrose Cave, a privy councillor. See TNA, SP $12 / 37 / 32$.

96 HMC, Report on the Manuscripts of Lord Middleton (London: H. M. Stationery Office, 1911), 518; Chapman, 217, 225, 231; CSPSp, 1558-1567, 468.

97 Doran, Circle, 45. The Grey sisters' mother, Frances of Suffolk, took Adrian Stokes, her master of the horse, as her second husband.
} 
alliances would be made with a continental power, no pro-monarch patron-client connections forged. ${ }^{98}$ By denying the queen's in loco parentis right to manage her marriage prospects while also displaying contemptuous, provoking behaviour toward the monarch with a secret wedding, Lady Mary ensured that her punishment would be swift and long-term, isolating and devoid of royal sympathy.

Unsurprisingly, Keys and Lady Mary's punishment took much the same trajectory as that of Hertford and Lady Katherine: questioning, imprisonment, High Commission investigation, and long-term house arrest. ${ }^{99}$ The one exception was that because Keys was non-noble his incarceration at the Fleet was exceedingly grim. ${ }^{100}$ Grindall, as High Commission judge, was tasked with examining the KeysGrey marriage though he was unable to claim that the marriage was invalid because there were too many witnesses. ${ }^{101}$ Elizabeth likely considered Grindall's verdict a setback but she continued the offenders' imprisonments despite their questionable legality. The unceasing detention demonstrates the queen's employment of the royal prerogative for the preservation of her position and the safety of the realm.

All of these punishments took a toll. Keys remained a "close prisoner" in the Fleet for at least two years ${ }^{102}$ but died in 1571.103 Lady Mary took very "grievously"104 Keys's death, but, after seven years' house arrest, she was "at free liberty [to] go."105 By 1577 Lady Mary was back at court, although she died one year later. Hertford, after nearly ten years of confinement, was finally allowed his freedom and permitted to return to court.106 While her sister and husband eventually achieved freedom, Lady Katherine's house arrest ended with her death

\footnotetext{
98 Because of Mary Grey's short stature and purported deformity, it might have been challenging to find her a suitable partner, but her royal lineage would have been in her favour. Sir Robert Cecil, son of Burghley and later first earl of Salisbury, had "splayed legs and a humpback" but these abnormalities did not keep him from marrying well and happily. See ODNB, s.v. "Cecil, Robert, first earl of Salisbury;" CSPV, 1603-1607, 41.

99 TNA, SP 12/37/23, 25, 27; APC, 1558-1570, 249, 252; CSPD, 1547-1580, 297. Lady Mary was placed under the charge of Katherine, dowager duchess of Suffolk, and, later, Sir Thomas Tresham who asked Burghley more than ten times to have her removed from his house. See CSPD, 1547-1580, 393-4, 410, 416-7, 421, 425, 429, 438, 433, 441.

100 CSPD, 1547-1580, 284. The Fleet warden "supplied [Keys] with a rib of roast beef for his dinner which had been immersed in a liquid wash prepared for mangy dogs."

101 TNA, SP 12/40/100. Failing to annul the marriage, Grindall referred the case to the Court of Arches. See ODNB, s.v. "Keys [née Grey], Lady Mary."

102 APC, 1558-1570, 265.

103 CSPD, 1547-1580, 295, 321.

$104 \mathrm{Ibid}, 422$.

105 TNA, SP 12/86/216.

106 Hertford remained at Hanworth until being imprisoned again in the Tower for his alleged role in Hales's 1564 succession tract. From the Tower he was placed under house arrest in various locations. See Rutton, 305-307; ODNB, s.v. "Seymour, Edward, first earl of Hertford."
} 
in 1568. So, too, ended the risk she had posed as the queen's heir presumptive. Many Protestants had looked to Lady Katherine, mourning "her loss, as they had fixed their eyes on her for the succession in any eventuality." Ambassador de Silva wrote to King Philip II, “The Queen expressed sorrow to me at her [Grey's] death, but it is not believed that she feels it, as she was afraid of her."107

Beginning with Lady Jane, Elizabeth viewed the Greys with fear and distrust as usurpers despite their shared commitment to Protestantism. ${ }^{108}$ By evading Henry VIII's will and the 1544 Succession Act, Lady Jane claimed the throne, denying both Mary and Elizabeth Tudor their rights to the succession. 109 Subsequently, Ladies Katherine and Mary contravened Elizabeth's monarchical rights with their clandestine marriages. As a result, the Grey sisters became impediments to the queen's authority and succession plan which was based on primogeniture-the Catholic Stuart line-rather than religion-the Protestant Suffolk line. At the start of her reign Elizabeth refused to acknowledge openly the challenge the Grey sisters presented to her position, perhaps either out of fear or from disbelief of the legitimacy of their claim. From the perspective of this thesis, it seems that she would have been able to manage them more effectively by personally selecting their marriage partners. When Elizabeth failed to do this, she lost the benefits her cousins' valuable royal lineage offered to the crown through their marriages. Nonetheless, following the Grey sisters' secret weddings Elizabeth reversed her approach to her cousins. Instead of ignoring these potentials heirs, she directly confronted the challenges the Grey sisters' claims and their unions presented to her.

Elizabeth clearly broadcast her carefully-guarded succession plan with deeds rather than words. This is reminiscent of her use of the silence of the royal prerogative, discussed in chapter four. The queen's open, strong, and decisive reaction to the Grey sisters' marriages was in itself an unambiguous response to and settling of the succession question. This is a fact that historians have passed over. Although the marriages were both alarming and daunting, they provided Elizabeth with unexpected, ideal opportunities to make royal prerogative-driven

107 CSPSp 1568-1579, 4.

108 Ives, 2; Starkey, 117; Doran, Circle, 30, 44.

109 Ives, 137-149; Doran, Monarchy, 16; Elton, ed., 3. Edward VI and John Dudley, duke of Northumberland's succession plan removed Mary and Elizabeth Tudor from the line of succession. 
decisions that affected the succession without engaging Parliament. The queen backed her anti-Suffolk line stance with conclusive action by means of the royal prerogative and its associated monarch-influenced courts High Commission and Star Chamber. With valid, ostensible purposes of maintaining monarchical authority and kingdom security, the courts issued verdicts which were aimed at ruining Hertford, Keys, and the Grey sisters with long-term imprisonment and fines and isolating them from any support, royal or otherwise. Additionally, Elizabeth counteracted Lady Katherine's sons' claims to the throne by lawfully confirming their illegitimacy. Her suppression of the Grey sisters' marriages helped to clear the way for the primogeniture-based claim of Mary, queen of Scots, the single person Elizabeth refused to exclude from inheriting the crown. ${ }^{110}$ Even though Elizabeth could not openly further a devout Catholic queen's bid for the English throne without angering Protestant supporters, Mary's "claim... was strengthened... by the disgrace of the Grey sisters," on which Elizabeth shrewdly capitalised. ${ }^{111}$ Her firm, unequivocal actions denied the marriages, separated the offenders, removed them from court, and delegitimised Lady Katherine's sons. Thus, Elizabeth guaranteed that the Suffolk line would not succeed where the Stuart line would.

\section{Lennox-Cavendish, 1574}

As Elizabeth voicelessly arranged her succession plan, in 1574 a very hasty and clandestine marriage took place in northern England between Charles Stewart, sixth earl of Lennox,112 and Elizabeth Cavendish, daughter of Elizabeth Talbot, countess of Shrewsbury, later known as "Bess of Hardwick."113 Lennox was a royal ward, his father having been murdered when he was 16-years-old.114 His mother, Margaret Stewart, dowager countess of Lennox, "had never really been trusted by either Mary [I] or Elizabeth because of... [her] claim to the English throne"115 and her devotion to Catholicism. ${ }^{116}$ As a result, though he lived with his

\footnotetext{
110 Doran, Monarchy, 3; Whitelock, 57.

111 Doran, Monarchy, 3.

112 Paul, ed., vol. 5, 354; CSPSc, 1571-1574, 280-281. Charles Stewart is also referred to as the "fifteenth/sixth earl of Lennox."

113 Stuart, Letters, 11.

114 Lennox's father, Matthew Stewart, fourth earl of Lennox, was murdered in 1571. See CSPSC, 1571-1574, 687-688.

115 Merton, 152.

116 Cokayne, ed., vol. 7, 599, 599n; ODNB, s.v. "Douglas, Lady Margaret, countess of Lennox."
} 
mother, it is highly probable that Lennox's wardship was retained by the crown ${ }^{117}$ due to the young earl's connections to the thrones of England as well as Scotland. ${ }^{118}$ Neither a royal ward nor royal, ${ }^{119}$ Cavendish's mother Bess had been a member of Elizabeth's household, acting as a gentlewoman of the privy chamber from 1559 to 1569.120 Significantly, Bess's fourth marriage to George Talbot, sixth earl of Shrewsbury, ${ }^{121}$ aligned her with England's premier earl ${ }^{122}$ who was also chief guardian of Mary, queen of Scots, during her exile. ${ }^{123}$

On 4 October 1574 the Privy Council ordered "A Commission for the taking up of two teams of horses or oxen, with their furniture, for removing of the Lady Lennox's stuff from Hackney unto her manor of Temple Newsham in Yorkshire." ${ }^{124}$ While breaking her northward journey at the home of Katherine Bertie, dowager duchess of Suffolk, the Lennoxes, mother and son, met Bess and Cavendish who were there discussing a potential marriage between Cavendish and Katherine of Suffolk's son, Peregrine Bertie. ${ }^{125}$ Bess extended an invitation to the Lennoxes for them to stay at her home at Rufford nearby-an invitation which was accepted. ${ }^{126}$ It seems Lennox and Cavendish quickly developed a romantic attachment while at Rufford; Bess, seeing an opportunity to unite her daughter with royal blood, "did her best to further... that match."127 In a letter to Leicester, Margaret of Lennox wrote "how desirous I have been to have had a match for him [Lennox]... And the Queen's Majesty, much to my comfort, to that end gave me good words at my departure." The woman that the queen had in mind for Lennox is not known. But, deeply in debt, disregarding the variation in rank, and because her son "had

117 I have been unable to locate any record of Lennox's wardship being sold. Margaret of Lennox wrote to Burghley requesting him to take her son into his home. See TNA, SP 12/83/7; Agnes Strickland, Lives of the Queens of Scotland, vol. 2 (New York: Harper \& Brothers, Publishers, 1851), 387-388. See also Hurstfield, Queen's Wards, 250, 255.

118 Lennox was a descendent of King Henry VII of England and King James II of Scotland. See ODNB, s.v. "Stewart, Henry, duke of Albany [known as Lord Darnley]."

119 Elizabeth Cavendish was not a royal ward even though her father, Sir William Cavendish, died when she was two. See $O D N B$, s.v. "Cavendish, Sir William." Sir William and Bess held much of their property jointly which prevented it from "falling into wardship." See ODNB, s.v. "Talbot, Elizabeth [Bess], countess of Shrewsbury." See also Mary S. Lovell, Bess of Hardwick: First Lady of Chatsworth 1527-1608 (London: Abacus, 2005), 107-108.

120 Merton, 266. Merton shows that Bess's name appeared from 1559 to 1563 and in 1566 and 1569 for her services in the privy chamber. See also Kinney, ed., 28. Kinney has noted that Bess was a member of Elizabeth's household from 1560 to 1567.

121 FSL, Cavendish-Talbot MSS, X.d.428 (129); Lisa Hopkins, ed., Bess of Hardwick: New Perspectives (Manchester: Manchester University Press, 2019), 6.

122 Hopkins, ed., 7; David N. Durant, Bess of Hardwick: Portrait of an Elizabethan Dynast (London: Peter Owen, 1999), 54; Lodge, 1838 ed., vol. 1, xxviii.

123 FSL, Cavendish-Talbot MSS, X.d.428 (87); Durant, Bess, 58.

124 APC, 1571-1575, 293.

125 William Fraser, The Lennox: Memoirs (1100-1600), vol. 1 (Edinburgh: s.n., 1874), 457.

126 Strickland, Queens of Scotland, vol. 2, 390.

127 BL, Cotton MSS, Caligula C/IV fol. 303. 
entangled himself so that he could have none other,"128 Margaret of Lennox decided to look favourably upon a union with the wealthy Cavendish and Talbot families. ${ }^{129}$ The regent of Scotland James Douglas, fourth earl of Morton, also speculated that "money should have been the ground" of the marriage. 130

With their mothers' encouragement, the couple wed at the end of October. $^{131}$ The earl of Shrewsbury confessed that the marriage "was dealt in suddenly and without my knowledge."132 Because of Lennox's royal ward status, the queen's authorisation was required for him to marry. ${ }^{133}$ Leaving Elizabeth uninformed was highly provoking and disrespectful to her especially considering both parties' close connections to the queen; the mothers' positions in particular were indefensible. Prior to the Lennox-Cavendish marriage, Bess's long service in the royal household meant that she was on excellent terms with Elizabeth, the pair exchanging New Year gifts since 1562.134 Writing to Bess in 1572, the queen was "well assured that your deeds have been such, as indeed we can conceive no such doubt but think ourselves assured of a faithful servant." 135 Within this relationship of trust and good will, Bess's furtive conduct regarding the marriage is baffling and her husband's position as gaoler of Mary, queen of Scots, only intensified the situation. Having already been incarcerated twice in Elizabeth's reign, Margaret of Lennox should have predicted the reaction to the rapid, private Lennox-Cavendish wedding, recalling that the queen had imprisoned her on account of her son Lord Darnley's marriage to Mary, queen of Scots, in 1565.136 But perhaps what should have been most obvious to both noblewomen was that Elizabeth did not appreciate claimants' tampering with the succession, as the Grey sisters' imprudent marriages had revealed.

128 TNA, SP 12/99/25; Strickland, Queens of Scotland, vol. 2, 392-393.

129 Stuart, Letters, 13; Sarah Gristwood, Arbella: England's Lost Queen (London: Bantam Press, 2003), 27.

130 CP, Vol. 147/39_3.

131 Stuart, Letters, 11.

132 BL, Cotton MSS, Caligula C/IV fol. 303.

133 Hurstfield, Queen's Wards, 131.

134 Jane A. Lawson, "Bess of Hardwick and Elizabeth St Loe," Notes and Queries 61 (2014): 209. The New Year's gift rolls from 1564 and 1565 are incomplete and the 1566 gift roll is no longer extant. Nevertheless, it is likely that Bess would have exchanged gifts with the queen during these years as well.

135 TNA, SP 53/8/19.

136 Margaret of Lennox was held in the Tower from 1565 to 1567 for the Darnley-Mary marriage. See TNA, SP 12/37/53. She had also been under house arrest from 1562 to 1563 for "telling people openly that her son Darnley would marry Mary," queen of Scots. See TNA, SP 12/23/66; ODNB, s.v. "Douglas, Lady Margaret, countess of Lennox." 
Upon hearing of the marriage the queen was infuriated not least because her approval had not been sought but also because any offspring from the union could disrupt her succession plan. She immediately summoned all offending parties to London for questioning. ${ }^{137}$ In a letter to Walsingham, Regent Morton encapsulated what would have likely been Elizabeth's concerns regarding the clandestine wedding:

some things fall out far contrarious to my expectation: namely, this late marriage of my Lord Charles, Earl of Lennox, which I wish had rather proceeded by the Queen's Majesty's pleasure and advice, for some honourable alliais [ally's] cause... I cannot but be sorry that my aunt, my lady his mother, and he should have proceeded as they have done in that matter, her Majesty's contentment not first procured, and I myself would have lippinit [trusted] for some knowledge of the matter before the consummation thereof, in consideration of the honour he has to be so near cousin to the King [James VI]... But as the whole proceeding is to me a mystery, so mon [must] I continue doubtful, and in suspense, till I see if any further matter be discovered, and in the meantime look the more carefully to such things as that cause may twiche [touch].138

The hurried marriage had called into question the participants' honour and loyalty to the queen, especially when Mary, queen of Scots, was nearby and under the Shrewsburys' care. Elizabeth, suspicious of Margaret of Lennox's motive for requesting permission to depart from court in the first place, was concerned that the countess would make contact with her former daughter-in-law, then prisoner at Shrewsbury's Sheffield Castle.139 In addition, French ambassador Bertrand de Salignac de La Mothe Fénélon reported to King Henry III that there were plans for Margaret of Lennox to kidnap the young King James VI and take him to England. ${ }^{140}$ How reliable this information was is unclear, but it is possible that Burghley and Elizabeth were aware of the plot. ${ }^{141}$ Furthermore, another rumour circulated that the exiled Scottish queen favoured the Lennox-Cavendish union as "she was the deviser of that marriage." 142 The French ambassador conveyed similar information to his king. ${ }^{143}$ If this was true, Elizabeth would have been furious to

\footnotetext{
137 ODNB, s.v. "Talbot, Elizabeth [Bess] [called Bess of Hardwick], countess of Shrewsbury;" Agnes Strickland, Life of Mary Queen of Scots, vol. 2 (London: George Bell and Sons, 1903), 320.

138 CP, Vol. 147/39_3.

139 ODNB, s.v. "Douglas, Lady Margaret, Countess of Lennox;" ibid, s.v. "Mary [Mary Stewart]."

140 Salignac, vol. 6, 254, 293; Durant, Bess, 83. See also CSPSp, 1568-1579, 491.

141 Durant, Bess, 86.

142 TNA, SP 53/10/9.

143 Salignac, vol. 6, 299-300.
} 
learn that Mary was privy and granted approval to a marital union of two English subjects, one of whom had a connection to the throne.

Lennox and Cavendish's marriage may have been devised beforehand by their two ambitious mothers, though Shrewsbury did seem convinced of at least Lennox's affection. In his apologetic post-wedding letter to the queen, Shrewsbury described that his step-daughter Cavendish had been "disappointed of young Bertie, whereof she hoped, and that the other young gentleman [Lennox] was inclined to love."144 Still, historians like Lisa Hopkins, David Durant, and Charlotte Merton have agreed that it does seem highly probable the secretive marriage scheme was carefully planned. ${ }^{145}$ This appears evident considering that Shrewsbury had written to Burghley mentioning that "there is few noblemen's sons in England that she [Bess] hath not prayed me to deal for, at one time or another."146 Because Shrewsbury had been actively involved in procuring a spouse for his stepdaughter in the past, the fact that he was unaware of the marriage further reveals an underhanded nature in its origin and execution. It is also possible that the union was engineered in anticipation of benefits to their respective families should Mary, queen of Scots, be named as Elizabeth's successor, as some thought she might. 147

In December 1574, the countesses, bearing "the heavy burden of the Queen Majesty's displeasure," arrived in London. ${ }^{148}$ By that time, the Lennox-Cavendish marriage was "not well taken in the Court,"149 regarded potentially as "a grab at royal rights." 150 The queen requested that Henry Hastings, third earl of Huntingdon, working alongside Walsingham, investigate the Lennox-Cavendish marriage and if any contact had been made with Mary, queen of Scots. ${ }^{151}$ Bess, though questioned, did not receive any punishment for her part in the marriage, probably due to her previous good relationship with the queen and Shrewsbury's

\footnotetext{
144 BL, Cotton MSS, Caligula C/IV fol. 303.

145 Hopkins, ed., 8-9; Durant, Bess, 84; Merton, 152.

146 Leonard Howard, A Collection of Letters from the Original Manuscripts of Many Princes, Great Personages and Statesmen (London: Printed for the Author, 1753), 237. Shrewsbury had sought the lords Rutland, Sussex, and Wharton as husbands for Cavendish. For Shrewsbury's letter regarding Philip Wharton, third baron Wharton, see CSPD, Addenda, 1566-1579, 411.

147 HMC, Bath, vol. 5, 3; Rawson, 145-146.

148 TNA, SP 12/99/23.

149 Lodge, 1838 ed., vol. 2, 45; Maud Stepney Rawson, Bess of Hardwick and Her Circle (New York: John Lane Company, 1910), 149.

150 Rawson, 147.

151 BL, Cotton MSS, Caligula C/IV fol. 306; Durant, Bess, 85.
} 
undisputed loyalty. ${ }^{152}$ The heaviest blame and reprimand fell upon Margaret of Lennox. ${ }^{153}$ Walsingham had uncovered questionable behaviour on the part of Margaret of Lennox's servants which suggested "Popish" connections and secret dealings with Mary. ${ }^{154}$ Elizabeth imprisoned Margaret of Lennox in the Tower where she remained until mid-1575 though she had broken no laws. ${ }^{155}$ She was guilty instead of "a political misdemeanour;"156 a misstep made worse by her royal blood. ${ }^{157}$ Her prolonged incarceration can be viewed as evidence of the royal prerogative in action-the queen's freedom to determine imprisonment of her subjects. The marriage she arranged for Lennox had touched on the succession and foreign relations with Scotland, two matters under the sole jurisdiction of the queen.

As it happened, Elizabeth did not punish the newlyweds. The validity of their marriage went unquestioned, suggesting that she did not believe that they were culpable; their mothers were. Nevertheless, had she been aware of the marriage beforehand, Elizabeth might have been able to benefit from Lennox's claimant status by matching him with a bride of whom she approved, as she had reassured Margaret of Lennox before her journey north. Regent Morton had expressed a similar view in his letter, wishing that Lennox's marriage had been arranged "for some honourable alliais [ally's] cause." The young earl might have been the means of establishing supportive, pro-Elizabethan government ties in Scotland. Still, as a Protestant and a member of a kinship network loyal to the queen, Cavendish perhaps was a suitable choice after all. This might also explain Elizabeth's lack of action taken against the union. That said, based on a 1575 letter, it appears that after their wedding the Lennoxes lived in a sort of exile, marginalised from royal favour; they were "socially taboo."158 Margaret of Lennox's Hackney home was far from court and Gilbert Talbot, Shrewsbury's son and heir, hoped "very shortly that the dregs of all misconstructions will be wiped

\footnotetext{
152 Durant, Bess, 87. See also CP, Vol. 158/136. Elizabeth selected Shrewsbury to join the Privy Council "for the special trust he deserves and for the honour of his estate... she is well assured of his fidelity."

153 Stuart, Letters, 14.

154 BL, Cotton MSS, Caligula C/IV fol. 306.

155 ODNB, s.v. "Douglas, Lady Margaret, Countess of Lennox"; Durant, Bess, 89.

156 Merton, 162.

157 David N. Durant, Arbella Stuart: A Rival to the Queen (London: Weidenfeld and Nicolson, 1978), 2.

158 Rawson, 157.
} 
away, that their abode there after this sort, will be altered." 159 In the end, the marriage was short-lived. Lennox, having evidently a "sickly" constitution, ${ }^{160}$ died in $1576^{161}$ and Cavendish passed away in $1582 .{ }^{162}$ They had one daughter, Lady Arbella Stuart, whose connection to the thrones of England and Scotland became a dilemma for Elizabeth and James in turn.

This thesis has previously argued in chapter four that Elizabeth acted with diffidence when faced with provocative upper-level noble marriages in the first decade of her reign. This chapter thus far has shown somewhat similar behaviour from the queen in that she initially refused to confront, or did so only hesitantly, the challenges her potential heirs presented to the succession. As a result, she lost significant opportunities to align would-be inheritors with suitable, perhaps foreign, Protestant spouses who would remain loyal to her regime while physically removing the claimants from the kingdom. The queen's delay in arranging to her benefit the marriages of her possible successors meant that three times she was forced to cope with the aftermath of their clandestine marriages. However, in the above examples a different side to the queen has also been exposed, one which existed alongside her irresolution. It is true that Elizabeth did not wish her courtiers to marry without her approval; this violated her in loco parentis responsibility. And, it is probably also true that she did not want her heirs to marry at all as she only very tentatively considered potential mates for Lady Katherine and Lennox. But, when faced with the disloyalty and wilful defiance displayed in their clandestine noble marriages, she responded as an assertive, experienced monarch, unequivocally and authoritatively.

The queen's approach ensured that those participants in unsanctioned clandestine weddings to which she was opposed were handled effectively time and again with imprisonment or banishment from court, deprivation of patronage, and physical and social isolation of offenders from the royal presence. It was a method which successfully prevented claimants from marshalling aid for their right to the

159 FSL, Cavendish-Talbot MSS, X.d.428 (108).

160 CSPD, 1601-1603, Addenda, 567; Cokayne, ed., vol. 7, 600n.

161 Cokayne, ed., vol. 7, 601.

162 TNA, SP 12/152/30; BL, Lansdowne MSS, Vol/34 fol. 2; Rawson, 234-235. 
throne. Most importantly, this punishment was consistently applied to those offenders from the beginning of her reign to the end, showing a tenacious defence of her power and authority throughout, not a loosening grip as some historians have suggested. ${ }^{163}$ As seen in Table 5.1 the frequency of monarchically-opposed and clandestine noble marriages was low and stable throughout the period. But these historians have commented on a supposed marked increase in secret weddings and illicit affairs, mostly among non-nobles, from 1590 to 1603, which Hammer, in particular, has interpreted as "a genuine and insidious challenge to Elizabeth's control of the court and, ultimately, to her princely authority."164 Doran has agreed with his appraisal, observing that the queen lost more than half of her maids of honour due to their "shotgun" weddings or unplanned pregnancies in 1591 alone. ${ }^{165}$ But all of these transgressions were among non-noble men and women, not the nobility which is the focus of this thesis. While Hammer has conceded that "We know much more about life at Elizabeth's court in the 1590s than the 1560s or 1570s and the quality of the evidence is much higher," the database has demonstrated that the numbers of clandestine noble marriages remained relatively constant, hovering between one and four per decade. ${ }^{166}$ Therefore, it becomes a challenge to view them as a reflection of loss of power over the court especially when the number actually peaked in the 1570s. This would indicate that the 1570s was the period of diminished power rather than the 1590s. But, having said that, chapter three of this thesis has already demonstrated that supportive involvement in alliances steadily increased throughout Elizabeth's reign. This has suggested a persistent and growing need to forge connections with the nobility. It is possible that Elizabeth, in the face of the number of clandestine relationships and marriages among her non-noble courtiers, countered by establishing tighter bonds with the nobility, sending a message of where she

\footnotetext{
163 See Hammer, "Sex and the Virgin Queen," 77-97. As mentioned in chapter one, Hammer's sample includes two clandestine noble marriages (Essex-Sidney and Southampton-Vernon), five affairs involving noblemen (three of which implicated Robert Devereux, second earl of Essex), four non-noble clandestine marriages, and two non-noble affairs, all of which occurred between 1590 and 1603. Furthermore, it is possible that Essex married as early as 1587 which would eliminate his marriage and leave only one clandestine noble marriage in the sample. See ODNB, s.v. "Devereux, Frances, countess of Essex and of Clanricarde." See also Rickman, 5, 43; Doran, Circle, 212.

164 Hammer, "Sex and the Virgin Queen," 91.

165 Doran, Circle, 212; Hammer, "Sex and the Virgin Queen," 90. The transgressions in 1591 involving maids of honour included Elizabeth Southwell's illicit pregnancy, Sir Robert Dudley's public wooing of Margaret Cavendish, the secret marriage of Sir Thomas Sherley Jr.'s to Frances Vavasour, and the secret marriage of Francis Darcy to Katherine Legh which was discovered when Legh gave birth at court.

166 Hammer, "Sex and the Virgin Queen," 91.
} 
believed her patronage should lie. If nothing else, secret aristocratic weddings provided Elizabeth with the opportunity to challenge conclusively those noble subjects who had defied her, and she invariably succeeded, leaving no doubt as to where power emanated.

\section{Jacobean case studies}

\section{Lennox-Ruthven, 1591}

James was still in his minority as king of Scotland when his uncle Charles Stewart, sixth earl of Lennox, died in 1576 and the earldom of Lennox reverted to the crown, rather than to Lennox's daughter Lady Arbella. ${ }^{167}$ In 1580 the young Scottish king bestowed the earldom upon his French cousin and favourite, Esmé Stuart, seigneur d'Aubigny. ${ }^{168}$ One year later James elevated Stuart's Lennox earldom to a dukedom, making him the premier nobleman in Scotland. With Esmé, first duke of Lennox's death in 1583, James sent for his son Ludovick Stuart, now second duke of Lennox, to be raised and educated in Scotland under his protection. 169 Once the young duke crossed the channel he resided in the royal household, becoming chamberlain of the household. ${ }^{170}$ The king, therefore, acted in loco parentis for his cousin and was responsible for seeking a suitable spouse for him. By the time Lennox was sixteen-years-old, several options had been mooted: "Some in England, and also [William Douglas, sixth earl of] Morton's daughter, were motioned to him to quench his desires." 171 However, James and Lennox's English cousin Lady Arbella Stuart was the main focus. As early as 1588 James expressed a desire for Lennox to marry Lady Arbella: "His majesty would... fain... have the Lady Arabella for this young duke, his kinsman, whom he loves dearly."172 Jamie Reid-Baxter has further noted that "wedding her to Ludovic would make the young duke a convincing candidate to be heir-apparent to both the Scottish and the

\footnotetext{
167 Cokayne, ed., vol. 7, 601, 602-604. In 1578 James bestowed the earldom on his great uncle Robert Stewart, bishop of Caithness, who became the seventh earl of Lennox. In 1580 the seventh earl resigned the Lennox title so that James could bestow it upon his cousin Esmé Stuart. The former seventh earl of Lennox then became the first earl of March. 168 Paul, ed., vol. 5, 356.

${ }^{169}$ RPC, vol. 3, 614, 588n-589n; HMC, Fourth Report, Part I, Report and Appendix (London: George Edward Eyre and William Spottiswoode, 1874), 527 [hereafter HMC, Fourth Report]; Cokayne, ed., vol. 7, 604n. See also HMC, Salisbury, vol. 3, 58.

170 HMC, Fourth Report, 527; Juhala, 310; Adrienne McLaughlin, "Rise of a Courtier: The Second Duke of Lennox and Strategies of Noble Power under James VI," in James VI and Noble Power in Scotland 1578-1603, ed. Miles Kerr-Peterson and Steven J. Reid (London and New York: Routledge, 2017), 136; Cokayne, ed., vol. 7, 604.

171 TNA, SP 52/46/58; BL, Cotton MSS, Caligula C/VIII fol. 450; CSPSC, 1586-1588, 81.

172 TNA, SP 52/42/128; Reid-Baxter, 211n. See also Winwood, vol. 1, 4; CSPSc, 1589-1593, 17; McLaughlin, 147.
} 
English thrones."173 Nevertheless, each of these proposals fell through and at some point Lennox became acquainted with Lady Lilias Ruthven, daughter of William Ruthven, first earl of Gowrie. ${ }^{174}$

Lady Lilias could not have been a more unsuitable choice for a bride. Her grandfather Patrick Ruthven, third lord Ruthven, had commanded the party which executed David Rizzio in front of the pregnant Mary, queen of Scots, in 1567.175 Her father, the first earl of Gowrie, had been an ardent supporter of the Elizabethan government, one of "the Anglophile, ultra-Protestant Scottish noblemen that would bring James to heel and... secure a sympathetic government up north."176 Gowrie, along with the earls of Angus and Mar and others, was responsible for the 1582 Ruthven Raid during which James was kidnapped and held in captivity for ten months. As a result of the raid the first duke of Lennox was ousted from his position of power in James's government and forced to return to France. ${ }^{177}$ Two years later, Gowrie's failed Stirling raid, another attempt at kidnapping James to control the government, saw the earl attainted for treason and executed. ${ }^{178}$ Furthermore, after the death of the first earl, it appears that Elizabeth encouraged the young second earl of Gowrie to marry Lady Arbella to connect the Ruthvens to the English throne and bypass James. ${ }^{179}$ That Lennox believed Lady Lilias an appropriate spouse is bewildering.

How Lennox and Lady Lilias met is unclear, though it may have been between October 1589 and April 1590 when James left Scotland for his marriage to Anne of Denmark. During James's absence Lennox had been appointed “viceroy or governor and he was to be assisted by [Francis Stewart, first earl of] Bothwell."180 In providing his guidance and expertise, Bothwell undoubtedly made an impression upon the young duke. ${ }^{181}$ Prior to James's departure, Bothwell had been

\footnotetext{
173 Reid-Baxter, 211.

174 TNA, SP 52/46/58.

175 Reid-Baxter, 210. Rizzio was Mary's secretary and favourite.

176 Doran and Kewes, eds., 33-34.

177 Steven J. Reid, "Of Bairns and Bearded Men: James VI and the Ruthven Raid," in James VI and Noble Power in Scotland 1578-1603, ed. Miles Kerr-Peterson and Steven J. Reid (London and New York: Routledge, 2017), 34; ODNB, s.v. "Ruthven raiders." Others involved included Patrick Lindsay, sixth lord Lindsay of the Byers and Thomas Lyon, master of Glamis.

178 ODNB, s.v. "Ruthven, William, fourth Lord Ruthven and first earl of Gowrie."

179 Reid-Baxter, 211-212n.

180 Robin G. Macpherson, "Francis Stewart, $5^{\text {th }}$ earl Bothwell, c 1562-1612: Lordship and Politics in Jacobean Scotland" (Ph.D. diss., University of Edinburgh, 1998), 282; McLaughlin, 138.

181 McLaughlin, 138.
} 
allied to anti-English interests, ${ }^{182}$ but the governorship "marked a resumption in the friendly contact between Bothwell and the agents of England." 183 Lennox and Bothwell wrote to Elizabeth with "good affections... [and] devotion"184 and the queen responded with "good disposition to the performance of all good offices that may tend to the maintenance and strengthening of the amity between us and our good brother the King, your sovereign, and particularly towards ourself." 185 Bothwell's shift in alliances likely brought the earl and Lennox into contact with other Protestant, pro-English magnates like the Ruthvens. ${ }^{186}$ It may be that this association led to Lennox's meeting Lady Lilias. But while James was still in Denmark, a faction had developed around Bothwell and Lennox "and once the king returned... James perceived Bothwell and his allies as a threat."187

By late October 1590, Lennox and Lady Lilias's relationship was widely known. Robert Bowes, Elizabeth's ambassador to Scotland, reported to Burghley that "The love betwixt the Duke of Lennox and Mrs. Lylias Ruthven, daughter to the Earl of Gowrie, deceased, is discovered to the King, who labours by all means to draw the Duke from that marriage." Many courtiers disliked the idea of a LennoxRuthven union: "Against the which also Huntly, Colonel Stewart, and other of the Duke's friends both set their shoulders and whole power, and also greatly prick and provoke the King to be earnest therein." Indeed, James and others feared that by associating with the Ruthvens there was no "doubting that by this match the Duke shall be drawn to associate himself to the party of Stirling," 188 a group of noblemen formerly headed by the first earl of Gowrie who opposed Chancellor James Maitland's policies to limit the power of the magnates. ${ }^{189}$ The king did not want Lennox entangled with that group. In addition, a Lennox-Ruthven match would "upset" the king's "long-cherished scheme" of making the duke his heirapparent for uniting the crowns. ${ }^{190}$ But, as Bowes conveyed, "he [Lennox]

\footnotetext{
182 Macpherson, 285-286; Keith M. Brown, Noble Power in Scotland from the Reformation to the Revolution (Edinburgh: Edinburgh University Press, 2011), 9.

183 ODNB, s.v. "Stewart, Francis, first earl of Bothwell."

${ }^{184}$ BL, Cotton MSS, Caligula D/I fol. 430.

185 TNA, SP 52/45/5.

186 Reid, 36; ODNB, s.v. "Ruthven, John, third earl of Gowrie."

187 ODNB, s.v. "Stewart, Francis, first earl of Bothwell."

188 TNA, SP 52/46/58; Reid-Baxter, 212. See also TNA, SP 52/46/13. Bowes writes of "the fellowship of Stirling."

189 Reid-Baxter, 212. The policies were those of James and Chancellor Maitland though the aristocracy held Maitland responsible for them. See ODNB, s.v. "Maitland, John, First Lord Maitland of Thirlestane."

190 Reid-Baxter, 211, 212.
} 
continues steadfast, to the great offence of the King and his friends, who for six or seven days have been occupied in this matter."191

To prevent an undesirable marital connection from occurring, "the King for the better surety of her [Lady Lilias] keeping out of the Duke's company had placed her," in Wemyss Castle, near Wester Wemyss. Situated across the Firth of Forth from Edinburgh, Wemyss Castle clearly seemed a secure enough location and a safe enough distance. But on 16 April 1591 "the Duke of Lennox went over the water to Wester Wemyss," forcibly "took out" Lady Lilias from Wemyss Castle, and "carried... her - unto the house of [John Stewart, fifth earl of] Atholl at Dunkeld and there married her." Lady Lilias's sister Mary was married to the earl of Atholl so it was there that they sought shelter and support. All of this was accomplished without James's knowledge or approval. Naturally, the king was "highly offended."192 As one of the king's closest kinsmen, when Lennox entered into an alliance with Lady Lilias, he defied his king's wish. He showed a provocative level of irreverence for the crown and connected the king with a treasonous family. Furthermore, James was deprived of the opportunity to select and approve a spouse for Lennox as was his in loco parentis right. James might have chosen another noblewoman from a less contentious family with whose family the king could make beneficial ties. In fact, the Lady Arbella marriage scheme continued into 1592.193

The king's anger at the effrontery of the misalliance resulted in the couple's brief banishment from court. The duke's crime of kidnapping was ignored-“the precedent of impudence without recourse was set."194 At the same time, it is likely that James overlooked Lennox's transgression for the sake of maintaining peace in the realm, deciding against the unrest a crown-enforced annulment might cause. In fact, on 15 April Bowes related that "means are to be made that he [James] will be pacified."195 Due to his close relationship with the king and the intercession of Queen Anne, Lennox returned to favour within weeks of his unwelcome marriage: “it is looked that the Duke shall be shortly restored to the King's good countenance

\footnotetext{
191 TNA, SP 52/46/58.

192 TNA, SP 52/47/41; Calderwood, vol. 5, 128; Reid-Baxter, 244; ODNB, s.v. "Stuart, Ludovick, second duke of Lennox." 193 TNA, SP 52/48/44.

194 McLaughlin, 147, 148.

195 TNA, SP 52/47/41.
} 
and to his offices in court." The duke and duchess of Lennox did return to court soon thereafter but their marriage was fleeting with Lady Lilias dying in 1592. 196

Rather than impacting the Scottish succession, the Lennox-Ruthven marriage touched on James's struggle for the English throne. Lennox's lack of punishment for his unsanctioned marriage to Lady Lilias can be viewed as an oblique message of its acceptance by the king. With the crown of England in his sights, it is highly likely that James decided not to marginalise the England-backed Ruthvens by forcing an annulment of the marriage, despite their resistance to his policies which limited upper-level noble influence. In overlooking the union, James showed his willingness to tolerate the duke's pro-England stance, made obvious through his marriage to Lady Lilias, as well as the new bond the wedding created between him and the staunchly Protestant, Anglophile Ruthvens; all for the sake of the English succession. ${ }^{197}$ From the 1590s to 1603, Lennox became "intimately associated with James's arrangement for pursuing the crown of England."198 The duke's connection with Bothwell, his contact with Elizabeth, and his marriage to Lady Lilias gave the appearance that he was supportive of English interests. When James quickly permitted Lennox's return to favour, his tacit approval of his cousin's actions and sentiments were made clear.

Seymour-Stuart, 1610

With Lennox's aid, James successfully ascended the throne of England in 1603. But four years later, the complex English succession was once more brought to light when the aging Edward Seymour, first earl of Hertford, petitioned James to have his and Lady Katherine's son and heir, Edward, lord Beauchamp, declared legitimate so that he might inherit the earldom. ${ }^{199}$ James approved the passing of the Hertford earldom to Beauchamp and his heirs upon the first earl's death, but he, significantly, did not remove the bastardy ruling. ${ }^{200}$ The king's maintenance of the Hertfords' sons' illegitimacy prevented them from being able to inherit the throne and removed the threat they might pose to his own line of succession. Still,

\footnotetext{
196 Ibid, SP 52/48/44; ibid, SP 52/48/62; Paul, ed., vol. 5, 357; McLaughlin, 148. 197 Reid, 47.

198 Cokayne, ed., vol. 7, 605n.

199 CP, Pet. 2368. See also HMC, Salisbury, vol. 19, 293.

200 CSPD, 1603-1610, 410.
} 
another candidate for the throne remained: James's first cousin, the English-born Lady Arbella Stuart.

From the instant of her birth in 1575, Lady Arbella began long, complicated, and distrustful relationships with her cousins-monarchs Elizabeth and James. The point of contention was her royal status which was captured in part by artist Rowland Lockey in his 1589 portrait of Lady Arbella. ${ }^{201}$ The description of her as Comitissa Leviniæ (Countess of Lennox), her rightful title denied her by the Scottish government, ${ }^{202}$ along with her richly bejewelled dress and fan symbolised her wealth and high position. But the dress's overall simplicity heralded Protestantism, while its colour, white, and the long strands of pearls both signalled her chastity. The presence of the dog demonstrated Lady Arbella's loyalty to the crown and the books revealed her education which was similar to that of Elizabeth. The symbols reminded the viewer of Lady Arbella's social importance but were also offered in dutiful praise of and tribute to the queen. ${ }^{203}$ The affluence and high rank reflected in the portrait underlined Lady Arbella's important position, one which was threatening to Elizabeth and James: she was of royal blood, with a claim to the throne, and of tremendous value in the marriage market. Offspring from any marriage Lady Arbella entered into could damage Elizabeth's succession plan and, prior to 1603, pose a risk to James's pursuit of the English crown, particularly since Lady Arbella was born in England.

For a time, Elizabeth actively managed Lady Arbella's marriage prospects. In 1585 the queen suggested her young cousin as James's consort. ${ }^{204}$ James's marriage to Lady Arbella would have mitigated the uncertainty of the succession as it would have joined the rights of two claimants. In the end, the decision was against Lady Arbella, with Sara Jayne Steen concluding that "that choice would have made James and Arbella so surely the heirs that it might have invited invasion from the north," potentially ending Elizabeth's rule. ${ }^{205}$ It was later reported that the Scots king "needs not Arabella's marriage to further his title [to the English throne], though he has been scared with her to keep him in order. It has been

\footnotetext{
201 British Library, “Portrait of Lady Arbella Stuart, 1589," accessed 13 November 2019, https://www.bl.uk/collectionitems/portrait-of-lady-arbella-stuart-1589\#.

202 BL, Harley MSS, 289 fol. 200; TNA, SP 52/27/51.

203 British Library, "Portrait of Lady Arbella Stuart, 1589."

204 TNA, SP 52/37/47; Gristwood, 43. See also CSPD, Addenda, 1580-1625, 411; CSPF, 1587-1587, 492

205 Stuart, Letters, 19.
} 
required that she should not be married without his consent."206 It is clear that James viewed Lady Arbella's proximity to the throne as competition and both he and Elizabeth would endeavour to manage her marriage prospects. To that end, Elizabeth invited Lady Arbella to join her court in 1587. To heal the growing breach between England and Spain, Elizabeth considered a marriage between Lady Arbella and Rainutio Farnese, son of Alexander Farnese, duke of Parma. ${ }^{207}$ The Farnese-Stuart proposed marriage endured prolonged negotiations, did nothing to prevent war between the two kingdoms, and ended in failure. ${ }^{208}$ Ludovick, duke of Lennox, was also proposed as a spouse to Lady Arbella after the death of his first wife. ${ }^{209}$ The prospect of this Anglo-Scottish noble marriage came to nothing. But it would have established strong ties at the highest level between the two countries, much like the Arran-Grey proposed marriage, while it would have also placed Lady Arbella fully under James's dominion.

In 1604, after James secured the English throne, he invited his cousin to join the court. While there, James did much to ensure Lady Arbella's fiscal security, especially since her financial state reflected directly on him. The king, "has given her [Lady Arbella] ten thousand crowns to pay her debts, and has also greatly increased her annual pension, and instead of eight dishes a day from the kitchen she is now allowed eighteen."210 By 1610, it was said that she lived comfortably on an annual sum of 4,000 ducats and had jewels that rivalled Queen Anne's. ${ }^{211}$ But, once Lady Arbella took up residence at court, James also became her guardian, assuming an in loco parentis role, and, as such, it became his responsibility to secure for her a suitable spouse.

Lady Arbella hoped that James, her king, guardian, and near male relation, would find an appropriately-ranked husband for her, just as she had vainly hoped from Elizabeth. ${ }^{212}$ Through Lady Arbella, Elizabeth and James might have forged ties with a continental power, extending their influence while gaining an ally. It

206 CSPD, Addenda, 1580-1625, 272. See also CP, Vol. 11/71.

207 CSPV, 1603-1607, 41; CSPSp, 1580-1586, 688; Gristwood, 68.

208 Stuart, Letters, 20, 21; Gristwood, 83.

209 TNA, SP 52/48/44. In 1599 a rumour circulated the Lady Arbella would marry the Duke Matthias. See CSPSC, 1597$1599,585$.

210 CSPV, 1607-1610, 433. In addition to her request for the return of the Lennox earldom, Lady Arbella requested and received licences for the sale of wine, beer, and whisky in Ireland. See TNA, SP 14/48/23; ibid, SP 14/141/38. 211 CSPV, 1607-1610, 86, 452; TNA, SP 14/31/59.

212 Emily Ross, "Spin-Doctoring Discourse: Ideological Debates around the Marriage of Lady Arbella Stuart and William Seymour," Comitatus 44 (2013): 203. 
does seem, however, that neither Elizabeth nor James wanted Lady Arbella to marry for the simple reason that her offspring could become rivals to the throne and possibly alter the succession. As Steen has observed, "A potential alliance was a wonderful diplomatic tool, but if a match were ever concluded, the game would be over. And thus no match was ever concluded."213 Indeed, historian Emily Ross has asserted that "there is no primary evidence that Arbella was offered any marriages," 214 though her name was linked to a number of possible partners including the dukes of Savoy and Moldovia as well as a German prince. ${ }^{215}$ Ultimately, none of these possible marriages came to fruition. James claimed that he was "prepared to let his cousin marry any faithful subject of his whom she might choose."216 Whether or not this stipulation included William Seymour, son and heir of Lord Beauchamp, is unclear. ${ }^{217}$ What is certain is that by 1610 Lady Arbella was dissatisfied and protested the king's treatment of her:

She complained loudly of the small account in which she is held, and recalled the frequent promises of the King. His Majesty has taken it all in good part... Her pension will be increased. All the same she publicly declares that she is not satisfied. She claims the restoration of her patrimony [earldom of Lennox] and asks to be married, or at least allowed to depart and to choose a husband.218

She had been living at court for seven years-ample time for James to locate a husband for her. And, now at thirty-five-years-old, Lady Arbella was no longer a ward; she was technically able to contract a marriage autonomously. ${ }^{219}$ But her presence in James's court and his in loco parentis role meant that she was still required to submit to his kingly and patriarchal authority.

In February 1610, a rumour circulated in Europe that Lady Arbella had married the twenty-two-year-old William Seymour. 220 Though it was untrue at the time, the hearsay was of deep concern to James as a "marriage of the lady Arabella,

\footnotetext{
213 Stuart, Letters, 22.

214 Ross, 204.

215 CSPV, 1603-1607, 117. James contemplated the idea of marrying Lady Arbella to the duke of Savoy. HMC, Report on the Manuscripts of the Marquess of Downshire, ed. E. K. Purnell and A. B. Hinds, vol. 2 (London: H. M. Stationery Office, 1936), 211 [hereafter HMC, Downshire]. See also TNA, SP 14/50/163; Henry Wotton, The Life and Letters of Sir Henry Wotton, ed. Logan Pearsall Smith, vol. 1 (Oxford: Clarendon Press, 1907), 414; CSPD, Addenda, 1580-1625, 411.

216 LKJ,320; Gristwood, 272; Lovell, 492; Gardiner, vol. 2, 115.

217 Ross, 193-194.

218 CSPV, 1607-1610, $414 .$.

219 Hurstfield, Queen's Wards, 137; Ross, 203.

220 HMC, Downshire, vol. 2, 240; TNA, SP 14/53/79.
} 
with the nephew [sic] of the Earl of Hertford should not go forward, so as to avoid the union of the claims of these two houses, who are the nearest to the Crown." As a result of the speculative reports, James met with Lady Arbella and Seymour in March and commanded them to cease interaction. ${ }^{221}$ Disregarding the king's personal mandate as well as his in loco parentis responsibility, the couple wed secretly in June. ${ }^{222}$ Their marriage was discovered two weeks later. Lady Arbella was held under house arrest in Lambeth, near London, while Seymour was sent to the Tower. ${ }^{223}$ But the couple's imprisonments were so insecure "that they had little difficulty in arranging meetings." Upon hearing this James ordered Lady Arbella's transfer north to be guarded by the bishop of Durham, while Seymour remained in London. ${ }^{224}$ In an act of defiance, they escaped their respective confinements, Lady Arbella in disguise, and reached the coast where they boarded separate ships headed for the continent. ${ }^{225}$ A proclamation went out for their apprehension.226 Seymour crossed successfully, but Lady Arbella's ship was overtaken in the Channel. She was escorted directly to the Tower and all subsequent requests for her release were dismissed. Because the couple had repeatedly disregarded his authority, James had no choice but to ensure they would never meet again and they did not. Lady Arbella's captivity in the Tower guaranteed that she would develop no court following nor support for her claim. Though there was "a report given out that the Lady Arbella should have a child," this was never proven.227 It was fortunate for the king that no child was conceived and thus there were no additional claimants to manage, as in Elizabeth's case regarding the Hertford-Grey marriage. In 1615 Lady Arbella, having become deeply depressed and delusional, died while still a prisoner in the Tower. ${ }^{228}$ Seymour remained in exile on the continent until 1616 when James finally allowed his return to England. ${ }^{229}$

The timing of the Seymour-Stuart marriage was especially problematic, arriving as it did during James's turbulent introduction to his English realm. Once

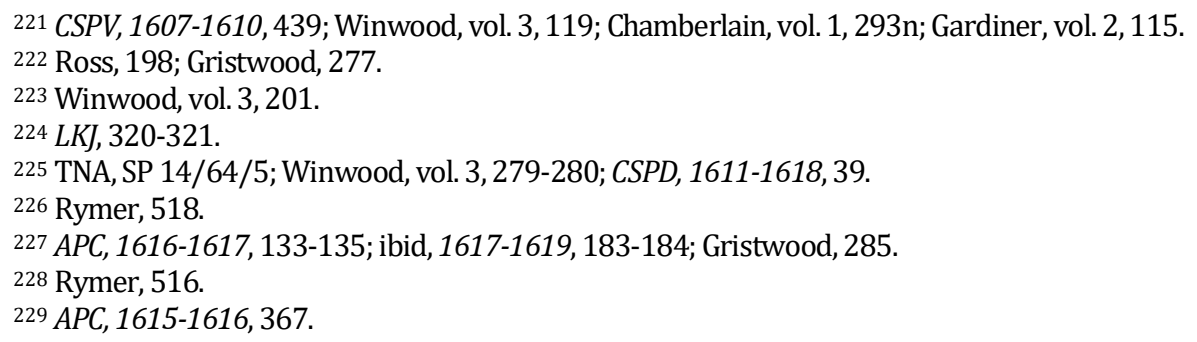


he ascended the throne, his opening years were disturbed by intrigue in the form of the 1603 Bye and Main plot and the 1605 Gunpowder plot, the former of which was linked nominally to Lady Arbella though she took no part in it. ${ }^{230}$ Intensifying the anxiety and agitation of this inaugural period were early partiality for his Scots courtiers, controversial Anglo-Scottish union plans, and financial negligence. ${ }^{231}$ When placed beside disagreements with the House of Commons and the failure of the Great Contract proposal to remedy overdrawn royal finances, James's misunderstandings and missteps had resulted in criticism. ${ }^{232}$ By 1610 , James had been seated on the throne of England for seven years and had his own settled, legitimate line of succession. Yet he still considered Lady Arbella a threat. ${ }^{233}$ Seen in the light of his own struggle for the English throne and the challenging early years of his English reign, James's perception of his cousin is understandable. James had been deeply anxious about his own succession to the English crown. Elizabeth's perpetual refusal to name him as her heir had added to his apprehension. Ultimately, he was unsure "whether Parliament... might deprive an expectant heir of his royal patrimony."234 The king, therefore, knew that England's Parliament had played an important role in determining the succession under Henry VIII, the precedent already existed, and any discontent with his rule or blatant acts of defiance of his authority could potentially incite parliamentary action against him and his line. ${ }^{235}$ And, finally, the affront of Seymour and Stuart's unauthorised, indeed expressly forbidden and rebellious, wedding implied that members of the nobility did not recognise the king's hierarchical supremacy and nor would they submit to his will. ${ }^{236}$

But courtiers like the earls of Salisbury and Nottingham believed that Lady Arbella's and Seymour's actions were non-threatening to the king, with Nottingham writing "that it does not appear to the world that there is here any

\footnotetext{
230 Howell, ed., vol. 2, 24, Gardiner, vol. 2, 114; Rymer, 511.

231 Croft, King James, 54, 57-58, 63-64; Lockyer, Britain, 256, 281; Rymer, 511, 512, 514.

232 Disagreements between James and the lower house arose over finances, the Anglo-Scottish union, impositions, and plural prerogatives of wardship and purveyance. See Croft, King James, 60-65, 75-82; Lockyer, Britain, 285. See also HMC, Downshire, vol. 2, 240; CSPD, 1603-1610, 625; ibid, 1611-1618, 310.

233 Croft, King James, 44.

234 Nenner, 15.

235 Russell, James, 145

236 CSPV, 1610-1613, 19. The Venetian ambassador referred to the Seymour-Stuart marriage as a "rebellion."
} 
great account moved of them." 237 Lady Arbella's protracted incarceration also provoked interest and sympathy from the public and contemporary writers. John Webster's The Duchess of Malfi, written around 1612, though based on the life of Giovanna d'Aragona, duchess of Amalfi, also corresponded to events in Lady Arbella's life. ${ }^{238}$ It dramatisedthe duchess's socially unequal but love-based clandestine marriage which was met with anger from her male relations. Like Lady Arbella, the duchess was imprisonedand died while in custody. ${ }^{239}$ A contemporary broadside, "The True Lovers Knot Untied," also chronicled the Seymour-Stuart marriage and portrayed Lady Arbella's dilemma:
Love is a knot none can unknit,
Fancy a liking of the heart,
Him whom I love I cannot forget,
Though from his presence I must part.
The meanest people enjoy their Mates
But I was born unhappily,
For being crost by cruel fates
I want both love and liberty. ${ }^{240}$

Despite the opinions of the public and of those courtiers around him, James believed that Lady Arbella and Seymour's clandestine marriage and attempted escape to the continent were part of religious plot against him. The 1610 assassination of the French King Henri IV by a zealous Catholic may have contributed to this idea and James's fear that he would share a similar fate. ${ }^{241}$ As a result, "Popish Recusants" were ordered to take the oath of allegiance denying papal authority. 242 The Venetian ambassador reported that "both parliament and

\footnotetext{
237 TNA, SP 14/64/4; Ross, 207; A. Audrey Locke, The Seymour Family, History and Romance (London: Constable and Company Ltd., 1911), 113.

238 John Webster, The Tragedy of the Dutchesse of Malfy As it was Presented Priuatly, at the Black-Friers; and Publiquely at the Globe, by the Kings Maiesties Seruants (London: Printed by Nicholas Okes, for Iohn Waterson, 1623). See also Rachel E. Holmes, "A Widow's Will: Adapting the Duchess of Amalfi in Early Modern England and Spain," Studies in Philology 116 (2019): 728-757; Sara Jayne Steen, "The Crime of Marriage: Arbella Stuart and The Duchess of Malfi," SCJ (1991): 61-76; British Library, "The Duchess of Malfi," accessed 13 November 2019, https://www.bl.uk/collectionitems/ /link.aspx?_id=9ED04C5D53EB41489B9373296BD3E4CC\&_z=z.

239 Holmes, 757.

240 Anonymous, The True Lovers Knot Untied, Being the Right Path Whereby to Advise Princely Vergins How to Behave Themselves, By the Example of the Renowned Princess, the Lady Arabella, and the Second Son of the Lord Seymore, Late Earl of Hartfort. To the Tune of, Frog's Galliart, \&c. Licensed and Entered According to Order (London: Printed by and for A. M., [between 1695 and 1700]). See also British Library, "Broadside Ballad 'The True Lovers Knot Untied,"' accessed 13 November 2019, https://www.bluk/collection-items/ /link.aspx?_id=8307A9EF6EBF4F50A5ED1604696A64D7\&_z=Z. 241 Gristwood, 305-306.

242 SR, vol. 4, 1162-1164: 7 Jac. I, 1609-1610, c. 6. This act was passed in the fifth session of James's first Parliament which took place from 16 October through 6 December 1610. See also ibid, vol. 4, 1071-1077: 3 Jac. I, 1605-1606, c. 4.
} 
council thought this the sole way to preserve the king's life." 243 According to Sarah Gristwood, upon hearing of the couple's escape, James "reacted with nearhysteria," fearful that the couple might muster support for their claim from Catholics on the continent. ${ }^{244}$ Lending credence to this theory was that Lady Arbella's aunt Mary Talbot, countess of Shrewsbury, had been a prime mover in the flight and was known to be "an obstinate popish recusant." 245 Amid this supposed Catholic plotting and attempted usurpation, the Seymour-Stuart marriage provided James with a critical opportunity to reinforce his authority in the face of previous imprudence, plotting, disagreements, and disappointments. His decisive reaction to Seymour's and Lady Arbella's escape demonstrated his resolute defence of monarchical power and the safeguarding of his carefully-built succession.

The king's 1611 letter to the bishop of Durham reflected his dismay at the Seymour-Stuart clandestine marriage:

\begin{abstract}
Whereas our cousin the Lady Arbella hath highly offended us in seeking to match herself without our knowledge (to whom she had the honour to be so near in blood) and in proceeding afterwards to a full conclusion of a marriage with the selfsame person whom, for many just causes, we had expressly forbidden to marry (after he had in our presence and before our Council forsworn all interest as concerning her either past or present...); forasmuch as it is more necessary for us to make some such demonstration now of the just sense and feeling we have of so great an indignity offered unto us as may make others know, by her example, that no respect of personal affection can make us neglect those considerations wherein both the honour and order of our government is interested. ${ }^{246}$
\end{abstract}

James directly referred to the effect that the unsanctioned wedding had on the government and, consequently, the state as a whole. With his authority and his kingdom's stability in the balance, James used the royal prerogative against the transgressors to ensure effective and long-lasting punitive measures against them. ${ }^{247}$ In fact, the manner in which James handled the threat presented by the Seymour-Stuart marriage showed him to be more fixed and unyielding in his response to Lady Arbella than Elizabeth had been towards Hertford, Keys, and the Grey sisters. Once Lady Arabella was captured after attempting to escape to the

243 CSPV, 1610-1613, 165; Gristwood, 305.

244 Gristwood, 305-306. See also Locke, 113.

245 Howell, ed., vol. 2, 770; Gristwood, 306.

246 LKJ, 320-321.

247 Carolyn Sale, “The 'Roman Hand': Women, Writing and the Law in the 'Att.-Gen. v. Chatterton' and the Letters of the Lady Arbella Stuart," ELH 70 (2003): 955. 
continent, she was imprisoned unremittingly in the Tower until her death. Like her grandmother Margaret of Lennox following the secret Lennox-Cavendish wedding, Lady Arbella's royal blood and nearness to the throne ensured that she would receive strict punishment. In addition, James never engaged prerogative courts like High Commission or Star Chamber, or any court, to investigate the Seymour-Stuart wedding as Elizabeth had done for the Grey sisters' marriages. As supreme governor of the church, James might have manipulated ecclesiastical judges to annul the Seymour-Stuart marriage as he would later do for the EssexHoward marriage in 1613. Butthe marriage must have been deemed legitimate since it was never examined and the king never pressed for an annulment. ${ }^{248}$ It is likely that general inexperience with the English courts, suspicion that judges would encroach on the "Prerogative of the Crown," and firm belief in the divine right of kings, led to James's sole use of the royal prerogative to manage Lady Arbella and Seymour as it allowed him to protect his authority, the stability of the realm, and his succession arrangement, regardless of legality. ${ }^{249}$ Furthermore, according to historian Carolyn Sale, Lady Arbella considered her long-term imprisonment unlawful and contacted chief justices Coke and Sir Thomas Fleming to request that they take her case for the purpose of limiting this "one exercise of the Royal Prerogative" by the king. ${ }^{250}$ The judges refused, too apprehensive to provoke the king. ${ }^{251}$ In the end, James's severe, unrelenting treatment of Lady Arbella probably stemmed from not only his cousin's obvious refusal to recognise his authority but also from a wider atmosphere of dissatisfaction with his rule in England. Nonetheless, his reaction to her crimes was conclusive and successful in that it eliminated the competition she posed and secured his succession plan.

\section{Conclusion}

Crown patronage is distinctly absent from this chapter because clandestine marriages were, by definition, private affairs that precluded the monarch's attendance, symbolic gestures, displays of approval, and patronage. These marriages were conducted secretly precisely because they usurped either the monarch's plural prerogative of wardships' marriages or his or her in loco parentis

\footnotetext{
248 Ross, 198-199.

249 JPW, 212-213, 214; Russell, James, 150-151, 152; idem, “Divine Rights,” 115-116; Sale, 955.

250 Sale, 955.

251 Ross, 202.
} 
responsibility. Noble couples who seized for themselves the power and authority of the monarch in one specific area were, in effect, perceived as seizing all power and authority: one seemingly small encroachment on monarchical authority could be understood as a total assault, especially in cases where the offender had a claim to the throne. Clandestine marriages resulted in significant lost opportunities for publicly parading the royal person, showing overt support of the marital juncture, and establishing those all-important, stabilizing monarch-noble patron-client bonds. At the same time, they provided opportunities to reassert monarchical will, authority, and policy and proved equally critical.

The clandestine marriages noted here frequently occurred in what were already tense, vulnerable moments, when aspects of policymaking had been confronted and monarchical authority seemingly undermined. For example, the House of Commons persistently called for greater religious reform and Elizabeth's marriage or named heir in the 1560s when the Grey sisters married illegally. Likewise, the Commons had vociferously hindered James's Anglo-Scottish union and questioned the Great Contract around the time of the Seymour-Stuart marriage. Each of these marriages forced unwanted debate or outcomes onto Elizabeth and James which served to question their leadership. Those unauthorised marriages which, like the House of Commons, challenged monarchical rights, provided Elizabeth and James with the opportunity, aided by the royal prerogative, to recover authority on a monarch-noble level, but that reclamation of power also represented a broader policy stance. Most of the marriages in this chapter have touched on the royal prerogative as it helped the monarch to secure succession, dominance over the church, direction of foreign policy, and peace in the realm.

In the cases relating to the succession, where at least one or sometimes both of the offenders could be considered an heir presumptive, royal approval of the marriage, though no longer a legal necessity, was an essential sign of respect for and obedience to the crown; aspects that were noticeably missing in the marriages presented here. Remarkably though, Elizabeth and James responded similarly to weddings that threatened their respective successions and they used the royal prerogative comparably. This is especially intriguing as James's succession was 
already secure while Elizabeth's was not. Elizabeth's thorough punishment of the Grey sisters' marriages, as well as her lack of recognition of the Strange-Spencer union described in chapter four, blocked the Suffolk line and cleared the way for the ascension of the Stuart line. She protected her own succession plan with the royal prerogative through High Commission and Star Chamber whose verdicts gave the appearance of legality and legitimacy. Keys's long imprisonment and the on-going house arrests of the Grey sisters and Hertford were also made possible through the royal prerogative because there was no legal reason for them.

James also used the royal prerogative to safeguard his succession following the unsanctioned Seymour-Stuart marriage. But he ignored even the appearance of a lawful, court-based handling of the offenders and their wedding, making obvious his reliance upon the royal prerogative to manage the event. As mentioned, his lack of familiarity with the English courts and belief that judges wished to curtail the royal prerogative likely resulted in his use of that monarchical privilege. In addition, his strong sense of divine right meant that he did not tolerate opposition. What is noticeable, however, is that where judges had found against the Hertford-Grey marriage according to Elizabeth's wishes, James seemed less certain of his desired verdict and so did not risk a court hearing of the Seymour-Stuart wedding. Yet following in Elizabeth's footsteps, he would later seek an annulment of the Essex-Howard marriage in 1613 through the High Commission because his position as supreme governor of the church helped to ensure an outcome favourable to the crown. James's dependence upon the royal prerogative to control the aftermath of Seymour-Stuart marriage caused courtiers and the public alike to question the need for prolonged punishment and resulted in sympathy for Lady Arbella's plight. A similar phenomenon occurred following Elizabeth's handling of the Hertford-Grey marriage. It was not easy to maintain authority in the face of provoking, unsanctioned marriages but the royal prerogative gave Elizabeth and James the upper hand to ensure successful handling. On the whole, it appears that Elizabeth's and James's policies and power, particularly relative to succession and the royal prerogative, were strengthened by the unsanctioned marital activities of the nobility. 
The delicate balance Elizabeth and James sought to achieve, when managing powerful members of the nobility, has been revealed in this chapter as well as chapter four. As described in chapter four, neither Elizabeth nor James could afford to create divisions, to become estranged from the most affluent and influential figures in noble society despite episodes of disloyalty and broken trust. The mutual benefit gained from positive rather than punitive monarch-noble relations needed to prevail for the stability of the kingdom and maintenance of royal authority, especially in the post-Rebellion north where Mary, queen of Scots, resided, or in the Highlands of Scotland where Huntly and Argyll held sway. As sovereigns, Elizabeth and James had to bring stability and tranquillity to their people. Their strong reactions to clandestine noble marriages exhibit how seriously they bore that duty in mind and sought to preserve their positions and the security of the realm, in part by controlling the succession. Interestingly, James wrote that "Those Princes who seek to secure themselves by Blood, shall find, the more they kill, the more they shall need to kill."252 Elizabeth and James, though faced with threats to their positions and successions that secret marriages presented, did not seek blood. Instead the transgressors endured isolation from royal favour and questionably legal, long-term imprisonment secured via the royal prerogative. Though Elizabeth's and James's punishments were publicly criticised, particularly in Lady Katherine's and Lady Arbella's cases, the resulting social ostracism proved effective.

${ }^{252} J P C, 26$. 


\section{Chapter 6}

\section{Conclusion}

Trouillot has written that "history is always produced in a specific historical context," and that "historical actors are also narrators." 1 In this sense, Elizabeth and James were lead actors and narrators on the stages of their respective reigns. Indeed, the preceding descriptions of noble weddings might easily be imagined in a theatrical setting. We may envisage Elizabeth and James centre stage, encouraging alliances among their nobles. We can picture their forceful, dramatic entries when they opposed aristocratic unions, particularly clandestine ones. Equally, we may imagine their passive observance from the wings of those marriages of which they were uncertain, watching the scenes play out. What have their actions revealed about their management of noble marriages? What has their involvement told us?

Elizabeth and James were selective in their respective practice of noblemarriage management. They did not involve themselves in every noble marriage. Instead, they participated where they received the greatest payoffs. That was generally with the upper-level nobility who possessed the most power and wealth. Both monarchs obtained the ability to influence large sections of the kingdom by connecting with the upper-level nobility at the event of their marriages. Positive monarch-noble relations were the key to maintaining royal authority and stability. Elizabeth's post-wedding support of the 1558 Norfolk-Audley marriage or James's encouragement of the 1558 Huntly-Stewart marriage indicates these efforts. Likewise, both monarchs skilfully used the royal presence as a gift to noble couples and their respective families as in the Warwick-Russell, Mar-Stewart, or HerbertRussell marriages. Elizabeth's or James's presence at a wedding was the highest honour, one which acknowledged the union of aristocratic families through marriage while it also circumvented an immediate need to offer anything concrete like monetary gifts, honours, privileges, or offices which generally followed later to maintain patron-client ties. James on numerous occasions, however, did provide 
both the gift of his attendance and a financial contribution as in the Herbert-Vere, Hay-Denny, and Somerset-Howard marriages. Royal presence at a marriage ceremony recognised the connection between noble families and achieved multiple goals: a public blessing upon the union, the initiation of a binding monarch-noble patron-client relationship, and an understood noble-to-monarch profession of loyalty and obedience which preserved the hierarchical supremacy of the crown.

Personally attending a wedding ceremony was just one way Elizabeth and James responded to aristocratic marital alliances. Categorising marriages by strategy-support, non-participation, or opposition-has exposed the basic methods Elizabeth and James employed to handle unions as previous chapters have already demonstrated. Most prominent among the strategies was advocacy. Both monarchs endorsed noble marriages throughout their reigns. They patronised joining families already allied to them, solidifying those associations, so forming larger noble kin networks pro-monarch in stance. By recognising these lateral connections in the hierarchy created by marriage, Elizabeth and James refocussed the new kinship bonds to themselves. Following marriage sponsorship, Elizabeth and James often used their exclusive privileges-the means by which they created a supportive network-to protect and grow the critical monarchnoble bonds initiated at a wedding. One purpose of this was to establish a sympathetic court through which they could work to express their political agendas, particularly relative to safeguarding Protestantism, securing the succession, and promoting Anglo-Scottish union. Conversely, monarchical silence or targeted non-participation, while self-protective, revealed usage of the royal prerogative. Silence implied wary anticipation until noble intentions and fidelity were confirmed. The horizontal links inaugurated through these marriages were potentially dangerous to the monarchy, necessitating a reticent approach. At the same time, silence was a tacit marginalisation of the offending couple when outright censure would have been imprudent. As a strategy, non-participation did not produce vital monarch-noble ties, but it was successful in maintaining royal dominance. Lack of involvement in noble marriages fell just short of the final strategy-unequivocal opposition. Elizabeth and James took exception to clandestine weddings, nearly always meeting them with some level of punishment. These unions typically evaded certain crown rights and removed the critical ability 
to establish beneficial, stabilising monarch-noble patronage links. Secret weddings also, on several occasions, connected to the succession. Wayward claimants and the succession question highlighted the vulnerability of both monarchs and the threat lateral bonds produced by marriage could be to the prevailing hierarchy. But, simultaneously, unauthorised marriages also provided opportunities to reassert monarchical will, authority, and policy.

Elizabeth and James expressed their beliefs, policies, and authority in similar ways, as their noble-marriage management practices have revealed. Both monarchs were committed Protestants, believers in divine right, protective of their privileges and prerogatives, and keen supporters of selected favourites. Yet, percentage-wise, James supported more noble marriages than Elizabeth (Table 3.1). By contrast, Elizabeth used a non-participatory approach more frequently than James (Table 2.2). What might have caused these differences in practice? One factor was that the number of peers increased dramatically during James's reign of England whereas it had remained relatively steady in the Elizabethan period. Other distinctions between them were obvious: unmarried versus married, nonparent versus parent, female versus male. John Guy has maintained that the sex of the monarch was an important issue during the early modern period. ${ }^{2}$ Elizabeth certainly understood that her gender implied weakness and her unmarried state made her seat on the throne vulnerable. It is possible that Elizabeth's position as a female monarch may have caused her tentative approach to the problematic marriages of powerful noblemen like Norfolk or Westmorland. James, on the other hand, embraced marriage and parenthood. He made evident his interest in and understanding of the importance of marriage as seen in the amount he wrote on the topic in Basilikon Doron. Wedlock and a secure succession might have accounted for greater confidence and, thus, a more supportive personal interest in brokering marriages.

Still, it is difficult to relate variances between Elizabeth and James solely to gender. This is because this thesis has demonstrated that the ways in which they used marital alliances to channel various royal powers has revealed their analogous approaches to monarchy relative to noble-marriage management.

2 Guy, 11. 
Indeed, Elizabeth's and James's similar responses to succession-related clandestine weddings reveal that self-preservation and enforcement of authority were principal objectives of monarchical rule, regardless of gender. On the whole, it has appeared that, in the practice of noble-marriage management at least, the office of the monarch had more direct impact than gender. This view is consistent with the work of Joan Kelly, Susan Amussen, and Frances Dolan, among others, who have observed that rank surpassed gender in this period and that even in a patriarchal society female authority was permissible in some situations. ${ }^{3}$ Indeed, this study offers some insight into early modern noblewomen's marriages and the elevated rank and authority which derived from wedlock. Of significance is that Elizabeth's and James's personal acknowledgement of and participation in weddings placed the bride's and groom's families on equal footing-both were necessary for the monarch to cultivate in order to maintain the hierarchy. Crown approval of a noblewoman's marriage could be life-altering in a positive way as the WarwickRussell and Norfolk-Audley case studies revealed. Lady Anne and Lady Margaret were invited to join the queen's household following their respective marriages, with Lady Anne, in particular, using her influence to recommend an appointee to a commission of peace. ${ }^{4}$ In addition, the Argyll-Cornwallis marriage highlighted the power Anne of Argyll had over her husband due to the role she likely played in encouraging his conversion to Catholicism. Furthermore, as seen in the HuntlyStewart marriage, Henrietta of Huntly's close relationship with both King James and Queen Anne was instrumental in easing her husband's punishment and returning him to royal favour. Whether they benefitted from royal favour or defied it, these noblewomen's marriages illustrate how the transition to wedlock offered some opportunities for female agency, authority, and independence in early modern England and Scotland.

Because Elizabeth's and James's noble-marriage management practice coincided in many respects, does this mean that their strategies connote a standardised practice? One wonders what noble-marriage management looked

3 Joan Kelly, Women, History \& Theory: The Essays of Joan Kelly (Chicago and London: University of Chicago Press, 1984), 27; Amussen, 3, 38-40, 187-188; Frances E. Dolan, "Gender and Sexuality in Early Modern England," in Gender, Power and Privilege in Early Modern Europe, ed. Jessica Munns and Penny Richards (London and New York: Routledge, 2014), 8; Susan Doran, “Did Elizabeth's Gender Really Matter?,” in Queens Matter in Early Modern Studies, ed. Anna Riehl Bertolet (Cham: Palgrave Macmillan, 2018), 33, 51-52; David Cressy, "Gender Trouble and Cross-Dressing in Early Modern England," Journal of British Studies 35 (1996): 464.

${ }^{4}$ Wall, “'The Greatest Disgrace,"” 315. 
like in the medieval period, or in France or Spain, or under other Tudor or Stuart monarchs, for instance. Stone has remarked that the Henry VIII rarely intervened in aristocratic marital alliances and Charles I, though he tried, had very little success in arranging or compelling noble marriages-the 1624 Monopolies Act would have affected his bargaining power. ${ }^{5}$ New scholarship might investigate other monarchs' noble-marriage management procedures for their effectiveness in handling the nobility and upholding royal hierarchy and authority. This would, in turn, shed light on Elizabeth's and James's own processes. Some variation would be expected between rulers due to the personal nature of monarchy. Elizabeth's and James's methods of noble-marriage management varied simply because each faced different problems or had different goals. Connecting patronage to policy, Elizabeth's involvement regularly upheld her Protestant religious settlement as in the Warwick-Russell marriage. Her participation in religion-related marriages remained high in the 1560s and 1570s, expressing her firm desire to reinforce Protestantism; it was likely also a response to Catholic plotting. As noted in chapter three, after 1571, Elizabeth tacitly communicated her unstated policy of converting England's Catholic aristocracy to Protestantism through marriage which revealed the silence of the royal prerogative and the monarch's free hand. Interdenominational weddings like the Oxford-Cecil, Herbert-Hastings, and Cumberland-Russell unions revealed that the queen's patronage of marital alliances was connected to her religious priorities. As explained in chapter four, Elizabeth used the non-participation strategy in the 1560s and the 1570s which was linked to open practice of Catholicism. In addition, Elizabeth had more succession-related marriages with which to contend than James. These weddings, which included the Grey sisters, Strange-Spencer, Lennox-Cavendish, and Beauchamp-Rogers marriages, had all taken place by the 1580s when Elizabeth had already personally chosen her successor, James. Doran and Kewes, Mueller, and others confirm that Elizabeth had selected her heir by the late 1580 s.

James, on the other hand, had one true rival to the throne, Lady Arbella, and he intervened less frequently than Elizabeth for the purposes of implementing his religious policy. This was perhaps because his tenure was less marked by a preoccupation with the survival of Protestantism. Instead, prior to 1603, the king

5 Stone, Crisis, 605, 608. 
used his approbation to foster greater harmony between opposing religious groups and factions at court. Notable examples were the Lindsay-Lyon and, later, the Mar-Stewart and Orkney-Livingstone marriages. These weddings represented James's early attempts at connecting patronage to a specific need: peace. After 1603, the Essex-Howard and Hay-Denny marriages were peace-making endeavours to bridge religious, national, and other factional differences within his court. In addition, the king's promotion of Anglo-Scottish union was fundamental to his reign whereas it was not an active policy in the Elizabethan period. James began supporting more Anglo-Scottish marriages from 1607 and using the royal prerogative to bypass Parliament's ruling against full union. Union marriages were further examples of James's efforts at linking patronage to policy. His involvement in the Hay-Denny and Somerset-Howard marriages, for example, demonstrated this action. Historians have argued over the effectiveness of the king's Briticisation endeavour, the intermarriages not producing any true cultural amalgamation. Chapter three has supported Galloway's research, proposing that immediate integration was not the intention. James's enduring legacy was his dream of Britain and he hoped that Anglo-Scottish marriages would eventually lead to its fruition. Following a spate of English-Scottish intermarriage, James's rate of participation declined in the 1610 s which may have been due to rule by favourites Somerset and Buckingham. Nonetheless, the king's involvement surged in the final five years of his reign, indicating a renewed desire to forge bonds with his aristocracy.

The achievements and contributions of this thesis, which has defined and exposed the noble-marriage management practices of Elizabeth and James, are positioned within the historiographies of monarch-noble relations and patronage. My research highlights the many opportunities available to Elizabeth and James through their involvement in weddings. It reveals that they used the occasions generated by marriages to align themselves with the nobility and to establish mutually beneficial relationships; both politically prudent decisions. My analysis underpins Ferguson's and McCormack's research on hierarchies which has recognised the danger that lateral connections posed to hierarchical systems as well as their inherent instability. This thesis emphasises how important it was for Elizabeth and James to maintain the hierarchical system of monarchy by 
successfully managing their relationships with the aristocracy. To that end, both monarchs' personal attendance at and participation in weddings theoretically promoted and stabilised their hierarchical dominance, as did swift punishments of unauthorised unions. But, by acknowledging and patronising newly-joined families at a marriage, Elizabeth and James attempted to draw kin groups' attention and allegiance from each other to the crown. This study supports the work of Heal, Kettering, Davis, and others who have underlined the significant place patron-client relationships held in early modern England and France, despite their unequal nature. It reinforces Farrell's idea that trust can exist between parties even within situations of power asymmetry like patronage. This thesis concurs with Barrow, showing that the patronage-client relationships inaugurated at weddings strengthened already-present monarch-noble ties. It also highlights Peck's research on the linking of patronage and policy, demonstrating that Elizabeth and James did implement their policies and ideas through their management of noble marriages.

Chapter three exhibits with statistics and case studies the positive and active nature of Elizabeth's and James's management of noble marriages for the establishment of solid monarch-noble bonds. This finding upholds Doran's and Hammer's observations that Elizabeth's participation, in particular, was largely affirmative. Conversely, it challenges Stone's generally negative interpretation of Elizabeth's interference in aristocratic marriages. It also adjusts Brown's view of Elizabeth's negligent attitude towards marital unions, showing that she was, in fact, actively and often sympathetically involved in weddings. Chapter four reveals that Elizabeth and James managed some upper-level noblemen's marriages with caution and silence to avoid open, public alienation of those influential figures. In doing so it specifically supports the scholarship of MacCaffrey, Alford, and Doran in highlighting Elizabeth's uncertainty in the 1560s. Chapter four has also emphasised the political science research of Larson and Farrell as well as Trouillot's anthropological studies. Their work aids in exposing the key roles trust and loyalty played in monarch-noble relations and the silence that sometimes accompanies power differentials. It also assists in elucidating power, the asymmetry of patronage, and trust, connecting these elements to the early modern monarch's duty to maintain dominance and protect the commonweal. 
Chapter five of this study proposes a new interpretation of clandestine marriages, rereading monarchical anger or jealousy as irritation at lost opportunities for creating stronger monarch-noble bonds or other prospects beneficial to the crown. It qualifies Rickman's view that clandestine marriages were common among the aristocracy at the Elizabethan court. Building on Doran's and Hammer's work, chapter five illustrates that the frequency of clandestine noble marriages actually peaked in the 1570s rather than the 1590s. In addition, the increase in unsanctioned marriages and secret affairs in the final decade of Elizabeth's reign is principally due to gentry or non-noble courtiers' illicit activities rather than noble courtiers'. Thus, the queen's connections with the nobility appear to have been strong during this period. This thesis shows that in the early modern world of patronage, aristocratic unions were pivotal in providing significant opportunities for linking the monarchy and nobility and solidifying the connections which sustained the prevailing hierarchy and royal power and privilege. As such, it supports, complements, and re-addresses previous scholarly works that have centred on monarch-noble relations and early modern patronage.

Frequent use of monarchical privileges, including plural and the royal prerogatives, for patronage and for the circumventing of Parliament, the Privy Council, and the courts was legally controversial and connoted absolutist activities. But how often did Elizabeth or James employ the royal prerogative when managing noble marriages? Can they be labelled as absolutist monarchs on account of their employment of the royal prerogative and other crown privileges? As the previous chapters have shown, Elizabeth and James used the royal prerogative in succession-related marriages and those they opposed by punishing as they saw fit rather than by relying on court-sanctioned sentences. The Buckingham-Manners marriage, in particular, highlighted "the issue of law versus prerogative" 6 relative to religious compliance and the exploitation of crown privileges like monopolies. Moreover, Briticisation and the encouragement of interdenominational marriages which drew Catholics to the Protestant faith were silent, subtle forms of the royal prerogative which disregarded or bypassed government input. Similarly, monarchical silence could be understood as usage of the royal prerogative to marginalise questionably loyal nobles and their suspicious marital alliances.

${ }^{6}$ Russell, James, 180-181. 
Recalling chapter two and the early modern meaning of "policy," the effort to convert Catholics through marriage, Briticisation, and marginalisation efforts aptly fit within its definition of political prudence and cunning-they were pragmatic and effective government practices.

The database and the examples described herein indicate that Elizabeth and James did rely heavily upon exclusive monarchical privileges. Their monarchies depended on these privileges because they were the basis of patronage, a system which placed the monarch as the dominant partner in every relationship. Because Elizabeth and James sought to maintain their power through the use of legallyquestionable crown privileges, their monarchies displayed aspects of absolutism: they sought to maintain authority through privileges over which only they had jurisdiction. Furthermore, they used those privileges to connect with the aristocracy and uphold the hierarchical system. This assessment coincides with the research of Miller, Goodare, and Johann Sommerville which has shown that Elizabeth's and James's regimes possessed characteristics of absolutism. ${ }^{7}$ But, at the same time, the database reveals the regularity with which each monarch supported the nobility through patronage-driven participation in their unions. What is more, the trends display a gradual increasing percentage or consistently high rate of supportive involvement in marriages (Table 3.1). What does this mean?

The nobility was the monarch's closest ally. Neither Elizabeth nor James wished to side-step that group when it was so necessary for their rule and the extension of crown authority and policies. This study has revealed that Elizabeth and James preferred joint rule and that monarch-noble relations during this period were generally favourable. It has also been clear that supportive participation predominated for both monarchs and produced longstanding patron-client bonds essential to stability and successful rule. Elizabeth and James needed and sought the aid of the nobility-their advocacy of marriages suggests that. Because supportive involvement at weddings forged positive monarch-noble bonds, it became one defence against growing resentment over crown privileges which

\footnotetext{
${ }^{7}$ Miller, ed., 197, 203-204; Goodare, Government, 89-90, 105-107, 111; Johann P. Sommerville, "Early Modern Absolutism in Practice and Theory," in Monarchism and Absolutism in Early Modern Europe, ed. Cesare Cuttica and Glenn Burgess (London: Pickering \& Chatto, 2012), 128-129.
} 
maintained royal supremacy and allowed Elizabeth and James to connect with their respective aristocracies. Indeed, removing exclusive royal benefits would curtail the establishment of monarch-noble connections - the monarch would have less to offer; his or her bargaining power would diminish. By eliminating the means through which the two groups were linked-patronage-the Commons would weaken the monarchy. And, they did, in part, with the 1624 Monopolies Act which made unlawful the granting of monopolies to individuals as had been the general practice. ${ }^{8}$ As a result, the high level of both monarchs' advocacy for marriages may be attributed to the Commons's growing hostility and, thus, may be viewed as an absolutist response. Moreover, Elizabeth's and James's steady and increasing engagement with the nobility corresponds with the work of Daryl Dee, Kettering, Sommerville, and others on the absolute monarchy of King Louis XIV of France. These historians have noted that Louis XIV consolidated his power with the support of the nobility, using them to connect to the government and provinces through patronage. ${ }^{9}$ Elizabeth's and James's noble-marriage management practices have shown that these aspects of Louis XIV's absolutist regime are analogous to their monarchies: their reliance on aristocratic backing for communication of policies and the maintenance of royal dominance.

In the end, Elizabeth's and James's handling of aristocratic marital alliances was dynamic. Their tactics included participation and support, avoidance and opposition. Both monarchs seized opportunities to channel myriad aspects of crown rule through their involvement in noble marriages - this made it a powerful tool for expressing and exercising royal authority and maintaining hierarchical dominance. Elizabeth and James transmitted policies, brought peace, and worked to foster cooperative and supportive aristocracies. They applied their plural prerogative of wards' and widows' marriages and in loco parentis rights and inaugurated new monarch-noble patron-client bonds that solidified pre-existing relationships. They employed the royal prerogative to manage unsuitable marriages which, at times, also meant manipulating judges, prolonging

\footnotetext{
8 Smith, Stuart Parliaments, 111.

9 Darryl Dee, Expansion and Crisis in Louis XIV's France: Franche-Comté and Absolute Monarchy, 1674-1715 (Rochester: University of Rochester Press, 2009), 6, 178; Sharon Kettering, "Brokerage at the Court of Louis XIV," HJ 36 (1993): 69, 82-83; Sommerville, 128-130; William Beik, Absolutism and Society in Seventeenth-Century France: State Power and Provincial Aristocracy in Languedoc (Cambridge: Cambridge University Press,1985), 15-16, 98; David Parker, Class and State in Ancien Régime France: The Road to Modernity? (London: Routledge, 1996), 79, 110, 181-182, 184, 268.
} 
punishments, and influencing the succession. But they likewise used the royal prerogative to forge their legacies of a long-lasting Protestant kingdom and a unified England and Scotland. Operating together, these crown privileges and capabilities effectively secured Elizabeth's and James's freedom and power to supervise and interfere in noble marital alliances, allowing them to achieve a promonarch balance of power and internal stability. Most importantly, it was through their involvement in marriages that Elizabeth and James perpetuated those allimportant monarch-noble connections and the patronage system which upheld a royal authority which was, on occasion, absolutist in nature. Noble-marriage management was, indeed, a single source for the implementation of many facets of early modern rule, making it a major apparatus of the monarchical office and a significant conduit of power. 


\section{Appendix}

\section{Imputed monarchical noble-marriage involvement, 1558-1625}

\begin{tabular}{|c|c|c|c|c|}
\hline Monarch & $\begin{array}{l}\text { Year of } \\
\text { marriage }\end{array}$ & Male, title & Female & Imputed monarchical involvement: comments/sources \\
\hline Elizabeth I & 1558 & $\begin{array}{l}\text { Thomas Howard, fourth } \\
\text { duke of Norfolk }\end{array}$ & $\begin{array}{l}\text { Margaret } \\
\text { Audley }\end{array}$ & $\begin{array}{l}\text { Non-participation; religious policy, Protestant intra-denomination union; widow's marriage. } \\
\text { See chapter four. }\end{array}$ \\
\hline Elizabeth I & 1560 & $\begin{array}{l}\text { Henry Neville, fifth earl } \\
\text { of Westmorland }\end{array}$ & $\begin{array}{l}\text { Margaret } \\
\text { Cholmeley }\end{array}$ & $\begin{array}{l}\text { Opposition; widow's marriage. After Westmorland controversially married his deceased } \\
\text { wife's sister, Elizabeth convened a High Commission panel to review the marriage. } \\
\text { See } C S P D, 1547-1580,185 ; O D N B \text {, s.v. "Neville, Henry, fifth earl of Westmorland." }\end{array}$ \\
\hline Elizabeth I & 1560 & $\begin{array}{l}\text { Edward Seymour, first } \\
\text { earl of Hertford }\end{array}$ & $\begin{array}{l}\text { Katherine Grey } \\
\text { [claimant] }\end{array}$ & Opposition; succession policy; clandestine marriage; in loco parentis. See chapter five. \\
\hline Elizabeth I & 1560 & $\begin{array}{l}\text { William Brooke, } \\
\text { tenth baron Cobham }\end{array}$ & $\begin{array}{l}\text { Frances } \\
\text { Newton }\end{array}$ & $\begin{array}{l}\text { Support; in loco parentis, Newton served in Elizabeth's household. See Rimbault, ed., 173; } \\
\text { Merton, 264-265; Kinney, ed., 28, 100; ODNB, s.v. "Brooke, William, tenth Baron Cobham." }\end{array}$ \\
\hline Elizabeth I & 1560 & $\begin{array}{l}\text { John Sheffield, second } \\
\text { baron Sheffield }\end{array}$ & $\begin{array}{l}\text { Douglas } \\
\text { Howard }\end{array}$ & $\begin{array}{l}\text { Support; in loco parentis, Lady Douglas served in Elizabeth's household. Elizabeth provided a } \\
\text { wedding gift on } 27 \text { October 1560. See Merton, 262; ODNB, s.v. "Sheffield [née Howard], } \\
\text { Douglas, Lady Sheffield." }\end{array}$ \\
\hline Elizabeth I & 1561 & $\begin{array}{l}\text { Walter Devereux, } \\
\text { second viscount } \\
\text { Hereford, later first earl } \\
\text { of Essex }\end{array}$ & Lettice Knollys & $\begin{array}{l}\text { Support; in loco parentis, Knollys was Elizabeth's cousin and served in her household. See } \\
\text { Merton, 263; Kinney, ed., 27, 108, 113; ODNB, s.v. "Dudley [née Knollys; other married name } \\
\text { Devereux], Lettice, countess of Essex and countess of Leicester." }\end{array}$ \\
\hline Elizabeth I & 1562 & $\begin{array}{l}\text { Sir Henry Percy; heir, } \\
\text { seventh earl of } \\
\text { Northumberland }\end{array}$ & $\begin{array}{l}\text { Katherine } \\
\text { Neville }\end{array}$ & $\begin{array}{l}\text { Non-participation; religious policy, interdenominational union. Percy, initially a favourite, } \\
\text { later plotted in support of Mary, queen of Scots, was imprisoned, and died in the Tower. See } \\
\text { De Fonblanque, 129, 140,145; Lomas, 121-126; Cokayne, ed., vol. 9, 730-7321; ODNB, s.v. } \\
\text { "Percy, Henry, eighth earl of Northumberland." }\end{array}$ \\
\hline
\end{tabular}


Royal Opportunity

\begin{tabular}{|c|c|c|c|c|}
\hline Monarch & $\begin{array}{l}\text { Year of } \\
\text { marriage }\end{array}$ & Male, title & Female & Imputed monarchical involvement: comments/sources \\
\hline Elizabeth I & 1563 & $\begin{array}{l}\text { Francis Talbot, styled } \\
\text { lord Talbot, heir to sixth } \\
\text { earl of Shrewsbury }\end{array}$ & Anne Herbert & Non-participation. See chapter four. \\
\hline Elizabeth I & 1563 & $\begin{array}{l}\text { Henry Herbert, styled } \\
\text { lord Herbert, heir to } \\
\text { first earl of Pembroke }\end{array}$ & $\begin{array}{l}\text { Katherine } \\
\text { Talbot }\end{array}$ & Non-participation. Lady Katherine later joined Elizabeth's household. See chapter four. \\
\hline Elizabeth I & 1563 & $\begin{array}{l}\text { Charles Howard, heir to } \\
\text { first baron Howard of } \\
\text { Effingham, later first } \\
\text { earl of Nottingham }\end{array}$ & $\begin{array}{l}\text { Katherine } \\
\text { Carey }\end{array}$ & $\begin{array}{l}\text { Support; in loco parentis, Lady Katherine was Elizabeth's cousin and served in her household. } \\
\text { See Merton, 259; Kinney, ed., 25, 30, 31, Kenny, 16; TNA, SP 70/60/100. }\end{array}$ \\
\hline Elizabeth I & 1564 & $\begin{array}{l}\text { Charles Neville, sixth } \\
\text { earl of Westmorland }\end{array}$ & Jane Howard & $\begin{array}{l}\text { Non-participation; religious policy, interdenominational union; in loco parentis. See chapter } \\
\text { four. }\end{array}$ \\
\hline Elizabeth I & 1565 & $\begin{array}{l}\text { Ambrose Dudley, earl of } \\
\text { Warwick }\end{array}$ & Anne Russell & $\begin{array}{l}\text { Support; religious policy, Protestant intra-denominational union. Elizabeth attended the } \\
\text { wedding. See chapter three. }\end{array}$ \\
\hline Elizabeth I & 1565 & Thomas Keys & $\begin{array}{l}\text { Mary Grey } \\
\text { [claimant] }\end{array}$ & Opposition; succession policy; clandestine marriage; in loco parentis. See chapter five. \\
\hline Elizabeth I & 1566 & $\begin{array}{l}\text { Francis Russell, second } \\
\text { earl of Bedford }\end{array}$ & Bridget Hussey & $\begin{array}{l}\text { Non-participation; widow's marriage. Bedford was a close, loyal servant of Elizabeth. See } \\
\text { Cokayne, ed., vol. 2, 76; ODNB, s.v. "Russell, Francis, second earl of Bedford." }\end{array}$ \\
\hline Elizabeth I & 1566 & $\begin{array}{l}\text { Henry Wriothesley, } \\
\text { second earl of } \\
\text { Southampton }\end{array}$ & Mary Browne & $\begin{array}{l}\text { Support; religious policy, Catholic intra-denominational union; ward's marriage } \\
\text { (Southampton was a royal ward). Elizabeth attended the wedding. } \\
\text { Broken patron-client relationship: Southampton imprisoned for alleged involvement in } \\
\text { Norfolk and Mary, queen of Scots's marriage. See Cole, 221; ODNB, s.v. "Wriothesley, Henry, } \\
\text { second earl of Southampton.” }\end{array}$ \\
\hline Elizabeth I & 1566 & $\begin{array}{l}\text { Henry Howard, heir to } \\
\text { first viscount Howard of } \\
\text { Bindon }\end{array}$ & $\begin{array}{l}\text { Frances } \\
\text { Mewtas }\end{array}$ & $\begin{array}{l}\text { Support; Howard was Elizabeth's cousin and Mewtas had previously served in Elizabeth's } \\
\text { household. See Kinney, ed., 33, 110; Cokayne, ed., vol 6, } 584 .\end{array}$ \\
\hline Elizabeth I & 1567 & $\begin{array}{l}\text { Thomas Howard, fourth } \\
\text { duke of Norfolk }\end{array}$ & $\begin{array}{l}\text { Elizabeth } \\
\text { Leybourne }\end{array}$ & $\begin{array}{l}\text { Non-participation; religious policy, interdenominational union; widow's marriage. See } \\
\text { chapter four. }\end{array}$ \\
\hline
\end{tabular}


Appendix

\begin{tabular}{|c|c|c|c|c|}
\hline Monarch & $\begin{array}{l}\text { Year of } \\
\text { marriage }\end{array}$ & Male, title & Female & Imputed monarchical involvement: comments/sources \\
\hline Elizabeth I & 1567 & $\begin{array}{l}\text { George Talbot, sixth } \\
\text { earl of Shrewsbury }\end{array}$ & $\begin{array}{l}\text { Elizabeth } \\
\text { Hardwick }\end{array}$ & $\begin{array}{l}\text { Support; widow's marriage. Shrewsbury was a close, loyal servant of the queen's and Lady } \\
\text { Elizabeth had previously served in the royal household. See FSL, Cavendish-Talbot MSS, } \\
\text { X.d.428; Merton, 132-133, 170; Kinney, ed., 28; Hopkins, ed. } 6 .\end{array}$ \\
\hline Elizabeth I & 1567 & $\begin{array}{l}\text { Henry Paget, second } \\
\text { baron Paget }\end{array}$ & $\begin{array}{l}\text { Katherine } \\
\text { Knyvett }\end{array}$ & $\begin{array}{l}\text { Support; in loco parentis, Knyvett served in Elizabeth's household. See Merton, 263; Kinney, } \\
\text { ed., } 29,33 \text {. }\end{array}$ \\
\hline Elizabeth I & 1571 & $\begin{array}{l}\text { William Parr, marquess } \\
\text { of Northampton }\end{array}$ & $\begin{array}{l}\text { Helena } \\
\text { Snakenborg }\end{array}$ & $\begin{array}{l}\text { Support; in loco parentis, Snakenborg served in Elizabeth's household; Northampton was a } \\
\text { close, loyal servant. Elizabeth attended the wedding. See Rimbault, ed., 160; Salignac, vol. 4, } \\
\text { 94; HMC, Rutland, vol. 1, 92; Camden, Annales, 283; Merton, 45-46; Kinney, ed., 29, 117; } \\
\text { Bradford, 59; ODNB, s.v. "Parr, William, marquess of Northampton." }\end{array}$ \\
\hline Elizabeth I & 1571 & $\begin{array}{l}\text { Edward de Vere, } \\
\text { seventeenth earl of } \\
\text { Oxford }\end{array}$ & Anne Cecil & $\begin{array}{l}\text { Support; religious policy, interdenominational union; ward's marriage (Oxford was a royal } \\
\text { ward). Elizabeth attended the wedding. } \\
\text { Broken patron-client relationship: Oxford converted to Catholicism. See chapter three. }\end{array}$ \\
\hline Elizabeth I & 1571 & $\begin{array}{l}\text { Philip Howard, styled } \\
\text { earl of Surrey, heir to } \\
\text { fourth duke of Norfolk } \\
\text { and twelfth earl of } \\
\text { Arundel }\end{array}$ & Anne Dacre & $\begin{array}{l}\text { Non-participation; religious policy, Catholic intra-denominational union; wards' marriage } \\
\text { (both Arundel and Lady Anne were royal wards). See chapter four. }\end{array}$ \\
\hline Elizabeth I & 1571 & $\begin{array}{l}\text { Edward Somerset, lord, } \\
\text { Herbert, heir to third } \\
\text { earl of Worcester }\end{array}$ & $\begin{array}{l}\text { Elizabeth } \\
\text { Hastings }\end{array}$ & $\begin{array}{l}\text { Support; religious policy, interdenominational union; in loco parentis. Elizabeth attended the } \\
\text { wedding. See chapter three. }\end{array}$ \\
\hline Elizabeth I & 1571 & $\begin{array}{l}\text { Edward Sutton } \\
\text { (Dudley), fourth baron } \\
\text { Dudley }\end{array}$ & Mary Howard & $\begin{array}{l}\text { Support; in loco parentis, Lady Mary was Elizabeth's cousin and served in her household. See } \\
\text { chapter three. }\end{array}$ \\
\hline Elizabeth I & 1571 & $\begin{array}{l}\text { Thomas Paget, fourth } \\
\text { baron Paget }\end{array}$ & $\begin{array}{l}\text { Nazareth } \\
\text { Newton }\end{array}$ & $\begin{array}{l}\text { Support; religious policy, Catholic intra-denominational union; in loco parentis, Newton } \\
\text { served in Elizabeth's household. } \\
\text { Broken patron-client relationship: Paget convicted of treason and attainted in } 1587 \text { for } \\
\text { Catholic plotting. See chapter three. }\end{array}$ \\
\hline Elizabeth I & 1571 & $\begin{array}{l}\text { Thomas West, heir to } \\
\text { first baron De La Warr }\end{array}$ & Anne Knollys & $\begin{array}{l}\text { Support; Knollys was Elizabeth's cousin and, after the wedding, served in her household. See } \\
\text { Merton, 263; Kinney, ed., 29, } 103 .\end{array}$ \\
\hline
\end{tabular}


Royal Opportunity

\begin{tabular}{|c|c|c|c|c|}
\hline Monarch & $\begin{array}{l}\text { Year of } \\
\text { marriage }\end{array}$ & Male, title & Female & Imputed monarchical involvement: comments/sources \\
\hline Elizabeth I & 1573 & $\begin{array}{l}\text { Edward Manners, third } \\
\text { earl of Rutland }\end{array}$ & Isabel Holcroft & $\begin{array}{l}\text { Support; in loco parentis, Holcraft served in Elizabeth's household. See HMC, Rutland, vol. 1, } \\
\text { 97; Merton, 126; Kinney, ed., 33, 122; ODNB, s.v. "Manners, Edward, third earl of Rutland." }\end{array}$ \\
\hline Elizabeth I & 1574 & $\begin{array}{l}\text { Charles Stewart, } \\
\text { fifteenth/sixth earl of } \\
\text { Lennox }[\mathrm{S}]\end{array}$ & $\begin{array}{l}\text { Elizabeth } \\
\text { Cavendish }\end{array}$ & $\begin{array}{l}\text { Opposition; succession policy; clandestine marriage; ward's marriage (Lennox was a royal } \\
\text { ward). See chapter five. }\end{array}$ \\
\hline Elizabeth I & 1574 & $\begin{array}{l}\text { George Carey, heir to } \\
\text { first baron Hunsdon }\end{array}$ & $\begin{array}{l}\text { Elizabeth } \\
\text { Spencer }\end{array}$ & $\begin{array}{l}\text { Support; Carey was Elizabeth's cousin and, after the wedding, Spencer joined the queen's } \\
\text { household. See Kinney, ed., } 30,111 .\end{array}$ \\
\hline Elizabeth I & 1575 & $\begin{array}{l}\text { William Brydges, heir to } \\
\text { third baron Chandos of } \\
\text { Sudeley }\end{array}$ & Mary Hopton & Support; in loco parentis, Hopton served in Elizabeth's household. See Kinney, ed., 30, 99. \\
\hline Elizabeth I & 1576 & $\begin{array}{l}\text { John Carey, heir to } \\
\text { second baron Hunsdon }\end{array}$ & Mary Hyde & $\begin{array}{l}\text { Support; Carey was Elizabeth's cousin; widow's marriage. See } O D N B \text {, s.v. "Carey, John, third } \\
\text { Baron Hunsdon." }\end{array}$ \\
\hline Elizabeth I & 1577 & $\begin{array}{l}\text { George Clifford, third } \\
\text { earl of Cumberland }\end{array}$ & $\begin{array}{l}\text { Margaret } \\
\text { Russell }\end{array}$ & $\begin{array}{l}\text { Support; religious policy, interdenominational union; ward's marriage (Cumberland was a } \\
\text { royal ward). Elizabeth attended the wedding. See chapter three. }\end{array}$ \\
\hline Elizabeth I & 1577 & $\begin{array}{l}\text { William Bourchier, } \\
\text { third earl of Bath }\end{array}$ & $\begin{array}{l}\text { Mary } \\
\text { Cornwallis }\end{array}$ & $\begin{array}{l}\text { Non-participation; clandestine marriage; ward's marriage (Bath was a royal ward); religious } \\
\text { policy, interdenominational marriage. See Weikel, 16, 21-22; HMC, Salisbury, vol. 11, 223; } \\
\text { ibid, Fifth Report, 138; ODNB, s.v. "Bourchier, William, third earl of Bath." }\end{array}$ \\
\hline Elizabeth I & 1577 & $\begin{array}{l}\text { Henry Herbert, second } \\
\text { earl of Pembroke }\end{array}$ & Mary Sidney & $\begin{array}{l}\text { Support; in loco parentis, Sidney served in Elizabeth's household. See Rimbault, ed., 160; } \\
\text { Merton, 232; Kinney, ed., 30, } 120 .\end{array}$ \\
\hline Elizabeth I & 1577 & $\begin{array}{l}\text { Peregrine Bertie, heir to } \\
\text { twelfth baroness } \\
\text { Willoughby }\end{array}$ & Mary de Vere & Support; in loco parentis, Lady Mary served in Elizabeth's household. See Kinney, ed., 29, 132. \\
\hline Elizabeth I & 1577 & $\begin{array}{l}\text { Philip Wharton, third } \\
\text { baron Wharton }\end{array}$ & $\begin{array}{l}\text { Frances } \\
\text { Clifford }\end{array}$ & $\begin{array}{l}\text { Support; religious policy, Catholic intra-denominational union; wards' marriage (both } \\
\text { Wharton and Clifford were royal wards). Elizabeth attended the wedding. See chapter three. }\end{array}$ \\
\hline Elizabeth I & 1578 & $\begin{array}{l}\text { Robert Dudley, earl of } \\
\text { Leicester }\end{array}$ & Lettice Knollys & $\begin{array}{l}\text { Opposition; clandestine marriage; widow's marriage. Leicester was a favourite of Elizabeth; } \\
\text { Lady Lettice was Elizabeth's cousin and had been a member of her household. Elizabeth's } \\
\text { hostility likely related to Leicester's earlier alleged marriage to Lady Douglas Howard. See } \\
\text { ODNB, s.v. "Dudley, Robert, earl of Leicester." }\end{array}$ \\
\hline
\end{tabular}


Appendix

\begin{tabular}{|c|c|c|c|c|}
\hline Monarch & $\begin{array}{l}\text { Year of } \\
\text { marriage }\end{array}$ & Male, title & Female & Imputed monarchical involvement: comments/sources \\
\hline Elizabeth I & 1579 & $\begin{array}{l}\text { Ferdinando Stanley, } \\
\text { lord Strange, heir to } \\
\text { fourth earl of Derby } \\
\text { [claimant] }\end{array}$ & Alice Spencer & Non-participation; succession policy. Also an interdenominational union. See chapter four. \\
\hline Elizabeth I & 1580 & $\begin{array}{l}\text { Thomas Burgh, heir to } \\
\text { fourth baron Burgh }\end{array}$ & $\begin{array}{l}\text { Frances } \\
\text { Vaughan }\end{array}$ & $\begin{array}{l}\text { Support; in loco parentis, Vaughn served in Elizabeth's household. See Merton, 39-40; Kinney, } \\
\text { ed., } 34,98 .\end{array}$ \\
\hline Elizabeth I & 1580 & $\begin{array}{l}\text { Robert Sackville, heir to } \\
\text { first baron Buckhurst }\end{array}$ & $\begin{array}{l}\text { Margaret } \\
\text { Howard }\end{array}$ & $\begin{array}{l}\text { Support; religious policy, interdenominational union; ward's marriage; Howard was } \\
\text { Elizabeth's cousin and a royal ward. See CSPD, 1581-1590, 139; ODNB, s.v. "Sackville, Robert, } \\
\text { second earl of Dorset." }\end{array}$ \\
\hline Elizabeth I & 1581 & $\begin{array}{l}\text { Edward Seymour, } \\
\text { styled lord Beauchamp, } \\
\text { heir to first earl of } \\
\text { Hertford [claimant] }\end{array}$ & Honora Rogers & $\begin{array}{l}\text { Support; succession policy; clandestine marriage. See HMC, Bath, vol. 4, xvi, 155-156, 159- } \\
\text { 160, 190-193; TNA, SP 12/154/77; ibid, SP 12/155/95; CSPD, Addenda, 1580-1625, 406; } \\
\text { Doran, Circle, 60-61; ODNB, s.v. "Seymour, Edward, first earl of Hertford." }\end{array}$ \\
\hline Elizabeth I & 1581 & $\begin{array}{l}\text { Robert Rich; third } \\
\text { baron Rich }\end{array}$ & $\begin{array}{l}\text { Penelope } \\
\text { Devereux }\end{array}$ & $\begin{array}{l}\text { Support; religious policy, Protestant intra-denominational union; in loco parentis, Lady } \\
\text { Penelope was Elizabeth's cousin and served in her household. See Freedman, 1; Merton, 40- } \\
\text { 41; Kinney, ed., 30, } 121 \text {. }\end{array}$ \\
\hline Elizabeth I & 1582 & $\begin{array}{l}\text { Edward Seymour, first } \\
\text { earl of Hertford }\end{array}$ & $\begin{array}{l}\text { Frances } \\
\text { Howard }\end{array}$ & $\begin{array}{l}\text { Opposition; clandestine marriage; in loco parentis, Lady Frances served in Elizabeth's } \\
\text { household. Elizabeth did not consent to the marriage until 1585. See HMC, Bath, vol. 4,148- } \\
\text { 149, 158; Merton, 128, 262; Kinney, ed., 29, 109; ODNB, s.v. "Seymour, Edward, first earl of } \\
\text { Hertford." }\end{array}$ \\
\hline Elizabeth I & 1583 & $\begin{array}{l}\text { Thomas Howard, later } \\
\text { first baron Howard de } \\
\text { Walden }\end{array}$ & $\begin{array}{l}\text { Katherine } \\
\text { Knyvett }\end{array}$ & $\begin{array}{l}\text { Non-participation; widow's marriage. Howard was Elizabeth's cousin. Within one year, } \\
\text { Howard was restored in blood and Knyvett later served in Elizabeth's household. See Sidney } \\
\text { Papers, vol. 2, 122; Merton, 192; Kinney, ed., 110; ODNB, s.v. "Howard [née Knyvett; other } \\
\text { married name Rich], Katherine, countess of Suffolk." }\end{array}$ \\
\hline Elizabeth I & 1584 & $\begin{array}{l}\text { Thomas Scrope, heir to } \\
\text { ninth baron Scrope }\end{array}$ & $\begin{array}{l}\text { Philadelphia } \\
\text { Carey }\end{array}$ & $\begin{array}{l}\text { Support; religious policy, interdenominational union; in loco parentis, Lady Philadelphia was } \\
\text { Elizabeth's cousin and served in her household. See Merton, 25, 37, 162; Kinney, ed., 30, 31, } \\
123 \text {. }\end{array}$ \\
\hline
\end{tabular}


Royal Opportunity

\begin{tabular}{|c|c|c|c|c|}
\hline Monarch & $\begin{array}{l}\text { Year of } \\
\text { marriage }\end{array}$ & Male, title & Female & Imputed monarchical involvement: comments/sources \\
\hline James VI/I & 1585 & $\begin{array}{l}\text { George Sinclair, fifth } \\
\text { earl of Caithness [S] }\end{array}$ & Jean Gordon & $\begin{array}{l}\text { Support; ward's marriage (Caithness was a royal ward); peace-making match. } \\
\text { Broken patron-client relationship: Caithness was believed to be Catholic and provoked } \\
\text { conflict with other nobles. See Cathcart, 174; Paul, ed., vol. 2, 342-343; ODNB, s.v. "Sinclair, } \\
\text { George, fifth earl of Caithness." }\end{array}$ \\
\hline James VI/I & 1585 & $\begin{array}{l}\text { Patrick Gray, heir to } \\
\text { fifth lord Gray }[\mathrm{S}]\end{array}$ & Mary Stewart & $\begin{array}{l}\text { Support; in loco parentis, Gray served in James's household. } \\
\text { Broken patron-client relationship: Gray was banished for his involvement in Mary, queen of } \\
\text { Scots's execution. See Juhala, 310; Paul, ed., vol. 4, 285-286. }\end{array}$ \\
\hline James VI/I & 1586 & $\begin{array}{l}\text { John Fleming, sixth lord } \\
\text { Fleming }[\mathrm{S}]\end{array}$ & Lilias Graham & $\begin{array}{l}\text { Support; ward's marriage (Fleming was a royal ward); in loco parentis, Fleming served in } \\
\text { James's household. See Juhala, 312; Paul, ed., vol. 8, 545-546. }\end{array}$ \\
\hline James VI/I & 1586 & $\begin{array}{l}\text { Alexander Home, sixth } \\
\text { lord Home [S] }\end{array}$ & $\begin{array}{l}\text { Christian } \\
\text { Douglas }\end{array}$ & $\begin{array}{l}\text { Support; ward's marriage (Home was a royal ward); widow's marriage. Within one year, } \\
\text { Home received a royal grant of lands. See Paul, ed., vol. 4,463-465. }\end{array}$ \\
\hline Elizabeth I & 1587 & $\begin{array}{l}\text { Robert Devereux, } \\
\text { second earl of Essex }\end{array}$ & $\begin{array}{l}\text { Frances } \\
\text { Walsingham }\end{array}$ & $\begin{array}{l}\text { Opposition; clandestine marriage; widow's marriage. Lady Frances later served in } \\
\text { Elizabeth's household. Essex was a favourite of Elizabeth. } \\
\text { Broken patron-client relationship: Essex led a rebellion in } 1601 \text { and was executed. See } \\
\text { Kinney, ed., 31, 106; ODNB, s.v. "Devereux, Frances, countess of Essex and of Clanricarde," } \\
\text { "Devereux, Robert, second earl of Essex." }\end{array}$ \\
\hline James VI/I & 1587 & $\begin{array}{l}\text { John Graham, sixth earl } \\
\text { of Menteith [S] }\end{array}$ & Mary Campbell & $\begin{array}{l}\text { Support; ward's marriage (Menteith was a royal ward). Menteith received a royal } \\
\text { dispensation to inherit his lands despite his minority just prior to his wedding. See Paul, ed. } \\
\text { vol. 6, 163-164. }\end{array}$ \\
\hline James VI/I & 1587 & $\begin{array}{l}\text { Andrew Stewart, heir to } \\
\text { second lord Ochiltree } \\
{[\mathrm{S}]}\end{array}$ & $\begin{array}{l}\text { Margaret } \\
\text { Kennedy }\end{array}$ & $\begin{array}{l}\text { Support; in loco parentis, Stewart served in James's household. See Juhala, 107, 310, 313; } \\
\text { Paul, ed., vol. 6, 513-516; Cokayne, ed., vol. 3, } 96 .\end{array}$ \\
\hline James VI/I & 1588 & $\begin{array}{l}\text { George Gordon, sixth } \\
\text { earl of Huntly }[\mathrm{S}]\end{array}$ & $\begin{array}{l}\text { Henrietta } \\
\text { Stewart }\end{array}$ & Support; religious policy, Protestant intra-denominational union. See chapter three. \\
\hline Elizabeth I & 1589 & $\begin{array}{l}\text { Henry Wentworth, } \\
\text { third baron Wentworth }\end{array}$ & Anne Hopton & Support; in loco parentis, Hopton served in Elizabeth's household. See Kinney, ed., 34, 130. \\
\hline James VI/I & 1590 & $\begin{array}{l}\text { Francis Hay, ninth earl } \\
\text { of Erroll }[S]\end{array}$ & $\begin{array}{l}\text { Elizabeth } \\
\text { Douglas }\end{array}$ & $\begin{array}{l}\text { Opposition; religious policy, interdenominational union. See TNA, SP 52/46/5, 7, 66; Brown, } \\
\text { Noble Society, 121; Paul, ed., vol. 3, 574-576; Cokayne, ed., vol. 5, 97; ODNB, s.v. "Hay, Francis, } \\
\text { ninth earl of Erroll." }\end{array}$ \\
\hline
\end{tabular}


Appendix

\begin{tabular}{|c|c|c|c|c|}
\hline Monarch & $\begin{array}{l}\text { Year of } \\
\text { marriage }\end{array}$ & Male, title & Female & Imputed monarchical involvement: comments/sources \\
\hline James VI/I & 1590 & $\begin{array}{l}\text { Alexander Lindsay, later } \\
\text { first lord Spynie [S] }\end{array}$ & Jean Lyon & $\begin{array}{l}\text { Support; widow's marriage; peace-making match. James arranged the marriage. See chapter } \\
\text { two. }\end{array}$ \\
\hline Elizabeth I & 1591 & $\begin{array}{l}\text { Anthony Maria Browne; } \\
\text { heir to first viscount } \\
\text { Montagu }\end{array}$ & Jane Sackville & $\begin{array}{l}\text { Support; religious policy, interdenominational union; ward's marriage (Browne was a royal } \\
\text { ward and Elizabeth's godson). Lady Jane was a Protestant relation of Elizabeth. } \\
\text { Broken patron-client relationship: due to his Catholicism, the Privy Council asked Browne } \\
\text { not to attend the } 1601 \text { Parliament. See } A P C, 1601-1604 \text {, xxvii, 221; Cokayne, ed., vol. 9, } 100 .\end{array}$ \\
\hline James VI/I & 1591 & $\begin{array}{l}\text { Ludovick Stuart, second } \\
\text { duke of Lennox }[\mathrm{S}]\end{array}$ & Lilias Ruthven & $\begin{array}{l}\text { Opposition; clandestine marriage; in loco parentis, Lennox was James's cousin and served in } \\
\text { his household. See chapter five. }\end{array}$ \\
\hline James VI/I & 1591 & $\begin{array}{l}\text { James Hay, seventh lord } \\
\text { Hay [S] }\end{array}$ & Margaret Ker & $\begin{array}{l}\text { Support. Hay was a loyal servant to the king. Hay received a royal charter for the lordship } \\
\text { and barony of Yester with a seat in Parliament on the same day as his marriage was } \\
\text { contracted. See Paul, ed., vol. 6, } 425-426 \text {. }\end{array}$ \\
\hline Elizabeth I & 1592 & $\begin{array}{l}\text { Edward de Vere, } \\
\text { seventeenth earl of } \\
\text { Oxford }\end{array}$ & $\begin{array}{l}\text { Elizabeth } \\
\text { Trentham }\end{array}$ & Support; in loco parentis, Trentham served in Elizabeth's household. See chapter three. \\
\hline James VI/I & 1592 & $\begin{array}{l}\text { John Erskine, } \\
\text { eighteenth/second earl } \\
\text { of Mar [S] }\end{array}$ & Mary Stewart & $\begin{array}{l}\text { Support; religious policy, Protestant intra-denominational union; peace-making match. } \\
\text { James arranged marriage. Lady Mary was James's cousin and Mar was a close, loyal servant. } \\
\text { See chapter three. }\end{array}$ \\
\hline James VI/I & 1592 & $\begin{array}{l}\text { William Maxwell, fifth } \\
\text { lord Herries [S] }\end{array}$ & Katherine Ker & $\begin{array}{l}\text { Support. Herries had served in James's household and in other positions and was a loyal } \\
\text { servant. See Paul ed., vol. 4, 414-415. }\end{array}$ \\
\hline James VI/I & 1593 & $\begin{array}{l}\text { John Graham, heir to } \\
\text { third earl of Montrose } \\
\text { [S] }\end{array}$ & $\begin{array}{l}\text { Margaret } \\
\text { Ruthven }\end{array}$ & Support. Within one year, Graham was serving in James's household. See Juhala, 311. \\
\hline Elizabeth I & 1594 & $\begin{array}{l}\text { Henry Percy, heir to } \\
\text { eighth earl of } \\
\text { Northumberland }\end{array}$ & $\begin{array}{l}\text { Dorothy } \\
\text { Devereux }\end{array}$ & $\begin{array}{l}\text { Support; religious policy, Protestant intra-denominational union. Lady Dorothy was } \\
\text { Elizabeth's cousin and had served in her household; widow's marriage. See Merton, 40-41; } \\
\text { Kinney, ed., 118; ODNB, s.v. "Percy, Henry, ninth earl of Northumberland." }\end{array}$ \\
\hline Elizabeth I & 1595 & $\begin{array}{l}\text { William Stanley, sixth } \\
\text { earl of Derby }\end{array}$ & $\begin{array}{l}\text { Elizabeth de } \\
\text { Vere }\end{array}$ & $\begin{array}{l}\text { Support; in loco parentis, Lady Elizabeth served in Elizabeth's household. Elizabeth attended } \\
\text { the wedding. See Kinney, ed., 34, 104; Wright, ed., vol. 2, 440; ODNB, s.v. "Stanley, William, } \\
\text { sixth earl of Derby." }\end{array}$ \\
\hline
\end{tabular}


Royal Opportunity

\begin{tabular}{|c|c|c|c|c|}
\hline Monarch & $\begin{array}{l}\text { Year of } \\
\text { marriage }\end{array}$ & Male, title & Female & Imputed monarchical involvement: comments/sources \\
\hline Elizabeth I & 1595 & $\begin{array}{l}\text { Thomas Berkeley, heir } \\
\text { to seventh baron } \\
\text { Berkeley }\end{array}$ & Elizabeth Carey & $\begin{array}{l}\text { Support; Lady Elizabeth was the queen's cousin and goddaughter and served in her } \\
\text { household. See Merton, 240; Cokayne, ed., vol. 2, 138-139; ODNB, s.v. "Chamberlain, } \\
\text { Elizabeth, Lady Chamberlain." }\end{array}$ \\
\hline Elizabeth I & 1595 & $\begin{array}{l}\text { William Sandys, third } \\
\text { baron Sandys }\end{array}$ & $\begin{array}{l}\text { Christian } \\
\text { Annesley }\end{array}$ & $\begin{array}{l}\text { Support; in loco parentis, Annesley served in Elizabeth's household. } \\
\text { Broken patron-client relationship: Sandys was involved in Essex's rebellion in } 1601 \text { and was } \\
\text { requested not to attend the } 1601 \text { Parliament. See Cokayne, ed., vol. 11, 445-446; APC, 1601- } \\
\text { 1604, xxvii, 218-219; Kinney, ed., 35, } 123 \text {. }\end{array}$ \\
\hline James VI/I & 1595 & $\begin{array}{l}\text { Patrick Lyon, ninth lord } \\
\text { Glamis [S] }\end{array}$ & Anne Murray & $\begin{array}{l}\text { Support; ward's marriage (Glamis was a royal ward). James attended the wedding. See } \\
\text { CSPSC, 1593-1595, 594, 601; Paul, ed., vol. 8, 291-294. }\end{array}$ \\
\hline James VI/I & 1595 & $\begin{array}{l}\text { Simon Fraser, sixth lord } \\
\text { Fraser [S] }\end{array}$ & Jean Stuart & Support; James attended the wedding. See CSPSc, 1593-1595, 604; Paul, ed., vol. 5, 530. \\
\hline James VI/I & 1596 & $\begin{array}{l}\text { Patrick Stewart, second } \\
\text { earl of Orkney }[S]\end{array}$ & $\begin{array}{l}\text { Margaret } \\
\text { Livingstone }\end{array}$ & $\begin{array}{l}\text { Support; widow's marriage; peace-making match. James attended the wedding. } \\
\text { Broken patron-client relationship: Orkney was attainted and beheaded in } 1615 . \\
\text { See CSPSC, 1595-1597, 306; Paul, ed., vol. 6, 575-576; ODNB, s.v. "Stewart, Patrick, second earl } \\
\text { of Orkney." }\end{array}$ \\
\hline James VI/I & 1597 & $\begin{array}{l}\text { John Kennedy, fifth earl } \\
\text { of Cassillis [S] }\end{array}$ & Jean Fleming & $\begin{array}{l}\text { Support; widow's marriage. Within one year, Cassillis was named to the Scottish Privy } \\
\text { Council and, later, appointed as lord high treasurer. } \\
\text { Broken patron-client relationship: Cassillis's quarrelsome, sometimes violent nature and } \\
\text { conflict with other nobles caused problems for the king. See Paul, ed., vol. 2, 475-477; Brown, } \\
\text { Noble Society, 117; ODNB, s.v. "Kennedy, John, fifth earl of Cassillis." }\end{array}$ \\
\hline James VI/I & 1597 & $\begin{array}{l}\text { John Maxwell, ninth } \\
\text { lord Maxwell [S] }\end{array}$ & $\begin{array}{l}\text { Margaret } \\
\text { Hamilton }\end{array}$ & $\begin{array}{l}\text { Support; ward's marriage (Maxwell was a royal ward). } \\
\text { Broken patron-client relationship: Maxwell quarrelled with other noblemen and later } \\
\text { murdered the laird of Johnstone, was convicted of treason, and executed. See CSPSC, 1597- } \\
\text { 1599, 78, 87; Paul, ed., vol. 6, 484-485; Brown, Noble Society, } 115 .\end{array}$ \\
\hline Elizabeth I & 1598 & $\begin{array}{l}\text { Henry Wriothesley, } \\
\text { third earl of } \\
\text { Southampton }\end{array}$ & $\begin{array}{l}\text { Elizabeth } \\
\text { Vernon }\end{array}$ & $\begin{array}{l}\text { Opposition; clandestine marriage; in loco parentis, Vernon served in Elizabeth's household. } \\
\text { See TNA, SP 12/268/76, 186; Sidney Papers, vol. 1,348; Chamberlain, vol. 1, 44; Rickman, 34; } \\
\text { Pearson, 110; Kinney, ed., 35, 125; Cokayne, ed., vol. 12/1, 129, 130n; ODNB, s.v. } \\
\text { "Wriothesley, Henry, third earl of Southampton." }\end{array}$ \\
\hline
\end{tabular}


Appendix

\begin{tabular}{|c|c|c|c|c|}
\hline Monarch & $\begin{array}{l}\text { Year of } \\
\text { marriage }\end{array}$ & Male, title & Female & Imputed monarchical involvement: comments/sources \\
\hline James VI/I & 1598 & $\begin{array}{l}\text { Ludovick Stuart, second } \\
\text { duke of Lennox }[\mathrm{S}]\end{array}$ & Jane Campbell & $\begin{array}{l}\text { Non-participation; widow's marriage; in loco parentis, Lennox was James's cousin and served } \\
\text { in his household. See RPC, 1592-1599, xcii; ibid, 1604-1607, 440, 551; Brown, Noble Society, } \\
\text { 135; Paul, ed., vol. 5, 497; ODNB, s.v. "Stuart [Stewart], Ludovick, second duke of Lennox and } \\
\text { duke of Richmond." }\end{array}$ \\
\hline Elizabeth I & 1600 & $\begin{array}{l}\text { Henry Somerset, lord } \\
\text { Herbert, heir to fourth } \\
\text { earl of Worcester }\end{array}$ & Anne Russell & $\begin{array}{l}\text { Support; in loco parentis, Lady Anne served in Elizabeth's household. Elizabeth attended the } \\
\text { wedding. See CP, Vol. 186/134; TNA, SP 12/275/6, 20; Nichols, Elizabeth, vol. 1, xii; Sidney } \\
\text { Papers, vol. 2, 195, 201, 203; Cooper and Eade, eds., 46-48; Cokayne, ed., vol. 12/2, 858. }\end{array}$ \\
\hline Elizabeth I & 1601 & $\begin{array}{l}\text { Henry Grey, heir to } \\
\text { seventh earl of Kent }\end{array}$ & $\begin{array}{l}\text { Elizabeth } \\
\text { Talbot }\end{array}$ & $\begin{array}{l}\text { Support; in loco parentis, Lady Elizabeth served in Elizabeth's household. See Merton, 41; } \\
\text { Kinney, ed., 31. }\end{array}$ \\
\hline Elizabeth I & 1601 & $\begin{array}{l}\text { Edward Seymour, first } \\
\text { earl of Hertford }\end{array}$ & $\begin{array}{l}\text { Frances } \\
\text { Howard }\end{array}$ & $\begin{array}{l}\text { Non-participation; clandestine marriage; widow's marriage. As Hertford had been } \\
\text { rehabilitated, Elizabeth likely deemed intervention unnecessary. See HMC, Bath, vol. 4, xvii, } \\
\text { 161-162; Kinney, ed., 109; ODNB, s.v. "Seymour, Edward, first earl of Hertford." }\end{array}$ \\
\hline Elizabeth I & 1601 & $\begin{array}{l}\text { Henry Brooke, eleventh } \\
\text { baron Cobham }\end{array}$ & $\begin{array}{l}\text { Frances } \\
\text { Howard }\end{array}$ & $\begin{array}{l}\text { Support; widow's marriage. Cobham was a close, loyal servant of Elizabeth. See Chamberlain, } \\
\text { vol. 1, 99; Cokayne, ed., vol. 3, 349; ODNB, s.v. "Brooke, Henry, eleventh Baron Cobham." }\end{array}$ \\
\hline James VI/I & 1603 & $\begin{array}{l}\text { James Hamilton, heir to } \\
\text { first marquess of } \\
\text { Hamilton [S] }\end{array}$ & $\begin{array}{l}\text { Anna } \\
\text { Cunningham }\end{array}$ & $\begin{array}{l}\text { Support; Hamilton was James's cousin. Within one year, Hamilton was appointed as a } \\
\text { gentleman of the bedchamber, a privy councillor, and steward of the royal household. See } \\
\text { Paul, ed., vol. 4, 373-375; ODNB, s.v. "Hamilton, James, second marquess of Hamilton." }\end{array}$ \\
\hline James VI/I & 1603 & $\begin{array}{l}\text { James Hamilton, first } \\
\text { lord Abercorn }[S]\end{array}$ & Marion Boyd & $\begin{array}{l}\text { Support; in loco parentis, Hamilton served in James's household and on the Scottish Privy } \\
\text { Council. See Paul, ed., vol. 1, 46-47; Cokayne, ed., vol. 1, } 2 \text {. }\end{array}$ \\
\hline James VI/I & 1604 & $\begin{array}{l}\text { William Douglas, } \\
\text { grandson \& heir, sixth } \\
\text { earl of Morton }[\mathrm{S}]\end{array}$ & Anne Keith & $\begin{array}{l}\text { Support; in loco parentis, Douglas served in James's household. See Paul, ed., vol. 6, 375-377; } \\
\text { Cokayne, ed., vol. 9, 294-296. }\end{array}$ \\
\hline James VI/I & 1604 & $\begin{array}{l}\text { William Herbert, third } \\
\text { earl of Pembroke }\end{array}$ & Mary Talbot & $\begin{array}{l}\text { Support; in loco parentis, Pembroke served in James's household. } \\
\text { See Cokayne, ed., vol. 10, 412-414; ODNB, s.v. "Herbert, William, third earl of Pembroke." }\end{array}$ \\
\hline James VI/I & 1604 & $\begin{array}{l}\text { Charles Howard, first } \\
\text { earl of Nottingham }\end{array}$ & $\begin{array}{l}\text { Margaret } \\
\text { Stewart }\end{array}$ & $\begin{array}{l}\text { Support; Anglo-Scottish union policy. See Lodge, } 1838 \text { ed., vol. 3, 40-41; Cokayne, ed., vol. 9, } \\
786 .\end{array}$ \\
\hline
\end{tabular}


Royal Opportunity

\begin{tabular}{|c|c|c|c|c|}
\hline Monarch & $\begin{array}{l}\text { Year of } \\
\text { marriage }\end{array}$ & Male, title & Female & Imputed monarchical involvement: comments/sources \\
\hline James VI/I & 1604 & $\begin{array}{l}\text { David Murray, first lord } \\
\text { Scone }[\mathrm{S}]\end{array}$ & $\begin{array}{l}\text { Elizabeth } \\
\text { Beaton }\end{array}$ & $\begin{array}{l}\text { Support; Murray had served in James's household and was a loyal servant. See Juhala, 311; } \\
\text { Paul, ed., vol. 8, 191-196; ODNB, s.v. "Murray, David, first viscount of Stormont." }\end{array}$ \\
\hline James VI/I & 1605 & $\begin{array}{l}\text { Charles Blount, earl of } \\
\text { Devonshire }\end{array}$ & $\begin{array}{l}\text { Penelope } \\
\text { Devereux }\end{array}$ & $\begin{array}{l}\text { Opposition. James against remarriage when first spouse was still living as in Lady Penelope's } \\
\text { case. See Cokayne, ed., vol. 9, 346n; Clarendon Papers, vol. 1, 2; Winwood, vol. 2, 206; } \\
\text { Chamberlain, vol. 1, 222; ODNB, s.v. "Blount, Charles, eighth Baron Mountjoy and earl of } \\
\text { Devonshire." }\end{array}$ \\
\hline James VI/I & 1605 & $\begin{array}{l}\text { William Knollys, first } \\
\text { baron Knollys }\end{array}$ & $\begin{array}{l}\text { Elizabeth } \\
\text { Howard }\end{array}$ & $\begin{array}{l}\text { Support; religious policy, interdenominational union. Within one year, Knollys was } \\
\text { appointed cofferer to Henry, prince of Wales, and later received multiple honours and offices. } \\
\text { Broken patron-client relationship: following his father-in-law the earl of Suffolk's disgrace, } \\
\text { Knollys fell from favour. See Cokayne, ed., vol. 1, 400-401; ODNB, s.v. "William Knollys, first } \\
\text { earl of Banbury." }\end{array}$ \\
\hline James VI/I & 1606 & $\begin{array}{l}\text { Thomas Howard, } \\
\text { fourteenth earl of } \\
\text { Arundel }\end{array}$ & Aletheia Talbot & $\begin{array}{l}\text { Support; religious policy, Catholic intra-denominational union; ward's marriage (Arundel } \\
\text { was a royal ward). Within one year, James stood as godfather to the couple's first son. See } \\
\text { Rimbault, ed., 174, 240; ODNB, s.v. "Howard, Thomas, fourteenth earl of Arundel, fourth earl } \\
\text { of Surrey, and first earl of Norfolk." }\end{array}$ \\
\hline James VI/I & 1606 & $\begin{array}{l}\text { Mungo Murray, first } \\
\text { lord Scone [S] }\end{array}$ & Anne Murray & $\begin{array}{l}\text { Support. Within one year, Scone received a royal charter of lands and other benefits followed } \\
\text { later. See Paul, ed., vol. 8, 196-197. }\end{array}$ \\
\hline James VI/I & 1607 & $\begin{array}{l}\text { George Gordon, styled } \\
\text { lord Gordon, heir to first } \\
\text { marquess of Huntly }[\mathrm{S}]\end{array}$ & Anne Campbell & $\begin{array}{l}\text { Support; peace-making match. James arranged marriage. Double wedding with Moray- } \\
\text { Gordon. See Paul, ed., vol. 4, 545-546; ODNB, s.v. "Gordon, George, second marquess of } \\
\text { Huntly." }\end{array}$ \\
\hline James VI/I & 1607 & $\begin{array}{l}\text { James Stewart, third } \\
\text { earl of Moray [S] }\end{array}$ & Ann Gordon & $\begin{array}{l}\text { Support; peace-making match. James arranged marriage. Double wedding with Gordon- } \\
\text { Campbell. See Paul, ed., vol. 6, 319-320. }\end{array}$ \\
\hline
\end{tabular}


Appendix

\begin{tabular}{|c|c|c|c|c|}
\hline Monarch & $\begin{array}{l}\text { Year of } \\
\text { marriage }\end{array}$ & Male, title & Female & Imputed monarchical involvement: comments/sources \\
\hline James VI/I & 1607 & $\begin{array}{l}\text { Alexander Elphinstone, } \\
\text { heir to fourth lord } \\
\text { Elphinstone }\end{array}$ & $\begin{array}{l}\text { Elizabeth } \\
\text { Drummond }\end{array}$ & $\begin{array}{l}\text { Support. Elphinstone was appointed senator of the college of justice just prior to his } \\
\text { marriage and within one year the couple received a royal charter of lands. See Paul, ed., vol. 3, } \\
540-541 \text {. }\end{array}$ \\
\hline James VI/I & 1607 & $\begin{array}{l}\text { James Hay, first lord } \\
\text { Hay [S] }\end{array}$ & Honora Denny & $\begin{array}{l}\text { Support; Anglo-Scottish union policy; in loco parentis, Hay was a favourite of James and } \\
\text { served in his household. See chapter three. }\end{array}$ \\
\hline James VI/I & 1608 & $\begin{array}{l}\text { John Lindsay, heir to } \\
\text { thirteenth earl of } \\
\text { Crawford [S] }\end{array}$ & Jean Abernethy & $\begin{array}{l}\text { Support. Lindsay's parents were well-known, loyal servants of James and Queen Anne. } \\
\text { Within one year, the couple received a royal charter of lands. See Paul, ed., vol. 3, 32-33. }\end{array}$ \\
\hline James VI/I & 1608 & $\begin{array}{l}\text { James Drummond, first } \\
\text { earl of Perth }[S]\end{array}$ & Isabel Seton & $\begin{array}{l}\text { Support. Perth "attracted the attention of the king" and served as a privy councillor and in } \\
\text { other capacities before and after his wedding. See Paul, ed., vol. 7, 48; Brown, Noble Society, } \\
117 \text {. }\end{array}$ \\
\hline James VI/I & 1608 & $\begin{array}{l}\text { William Cecil, heir to } \\
\text { first earl of Salisbury }\end{array}$ & $\begin{array}{l}\text { Katherine } \\
\text { Howard }\end{array}$ & $\begin{array}{l}\text { Support; peace-making match. The fathers of the couple, the earls of Salisbury and Suffolk, } \\
\text { were close, loyal servants of James. Cecil later became a loyal servant of James. See Cokayne, } \\
\text { ed., vol. 11, } 406 ; \text {; ODNB, s.v. "Cecil, William, second earl of Salisbury." }\end{array}$ \\
\hline James VI/I & 1608 & $\begin{array}{l}\text { Thomas Windsor, sixth } \\
\text { baron Windsor }\end{array}$ & $\begin{array}{l}\text { Katherine } \\
\text { Somerset }\end{array}$ & $\begin{array}{l}\text { Support; ward's marriage (Windsor was a royal ward). The wedding probably took place at } \\
\text { court. See Nichols, James, vol. } 2,174,349 \text { n; Cokayne, ed., vol. } 12 / 2,799-800 \text {. }\end{array}$ \\
\hline James VI/I & 1608 & $\begin{array}{l}\text { William Cavendish, heir } \\
\text { to first baron Cavendish }\end{array}$ & Christian Bruce & $\begin{array}{l}\text { Support; Anglo-Scottish union policy. James arranged marriage. James gave Bruce away } \\
\text { during the ceremony and made up part of her marriage portion. See Lodge, } 1791 \text { ed., vol. } 3 \text {, } \\
\text { 350-353; Cokayne, ed., vol. } 4,340 \text {. }\end{array}$ \\
\hline James VI/I & 1609 & $\begin{array}{l}\text { Archibald Campbell, } \\
\text { seventh earl of Argyll } \\
\text { [S] }\end{array}$ & $\begin{array}{l}\text { Anne } \\
\text { Cornwallis }\end{array}$ & $\begin{array}{l}\text { Non-participation; religious policy, interdenominational union. Also an Anglo-Scottish } \\
\text { marriage. See chapter four. }\end{array}$ \\
\hline James VI/I & 1609 & $\begin{array}{l}\text { Esmé Stewart, seventh } \\
\text { seigneur d'Aubigny } \\
\text { [Fr]; heir to second } \\
\text { duke of Lennox [S] }\end{array}$ & $\begin{array}{l}\text { Katherine } \\
\text { Clifton [heiress, } \\
\text { first baron } \\
\text { Clifton] }\end{array}$ & $\begin{array}{l}\text { Support; Anglo-Scottish union policy; in loco parentis, d'Aubigny was James's cousin and } \\
\text { served in his household. James arranged marriage. See HMC, Laing, vol. 1, 106-107; Lodge, } \\
1838 \text { ed., vol. 3, 208; Cust, 98; Stone, Crisis, 102; Cokayne, ed., vol. 7, 612; ODNB, s.v. "Stuart, } \\
\text { Esmé, third duke of Lennox." }\end{array}$ \\
\hline James VI/I & 1609 & $\begin{array}{l}\text { John Ramsay, viscount } \\
\text { Haddington }[\mathrm{S}]\end{array}$ & $\begin{array}{l}\text { Elizabeth } \\
\text { Radcliffe }\end{array}$ & $\begin{array}{l}\text { Support; Anglo-Scottish union policy; in loco parentis, Haddington served in James's } \\
\text { household. See Lodge, } 1838 \text { ed., vol. 3, 208; Rimbault, ed., 161; TNA, SP 14/26/79; Macray, } \\
\text { ed., 17-18; Juhala, 313; Cokayne, ed., vol. 6, 534. }\end{array}$ \\
\hline
\end{tabular}


Royal Opportunity

\begin{tabular}{|c|c|c|c|c|}
\hline Monarch & $\begin{array}{l}\text { Year of } \\
\text { marriage }\end{array}$ & Male, title & Female & Imputed monarchical involvement: comments/sources \\
\hline James VI/I & 1609 & $\begin{array}{l}\text { Emanuel Scrope, } \\
\text { eleventh baron Scrope }\end{array}$ & $\begin{array}{l}\text { Elizabeth } \\
\text { Manners }\end{array}$ & $\begin{array}{l}\text { Support. Immediately following the wedding, Scrope was named bailiff of Richmond, } \\
\text { constable of Richmond and Middleham Castles. See Cokayne, ed., vol. 9, 550-551. }\end{array}$ \\
\hline James VI/I & 1610 & $\begin{array}{l}\text { John Erskine, styled } \\
\text { lord Erskine, heir to } \\
\text { eighteenth/second earl } \\
\text { of Mar [S] }\end{array}$ & Jean Hay & $\begin{array}{l}\text { Support; religious policy, interdenominational union. The Erskines were close, loyal servants } \\
\text { of James. See Juhala, 119; ODNB, s.v. "Erskine John, nineteenth or third earl of Mar;" } \\
\text { "Erskine, John, eighteenth or second earl of Mar." }\end{array}$ \\
\hline James VI/I & 1610 & $\begin{array}{l}\text { William Seymour, later } \\
\text { second earl of Hertford }\end{array}$ & $\begin{array}{l}\text { Arbella Stuart } \\
\text { [claimant] }\end{array}$ & $\begin{array}{l}\text { Opposition; succession policy; clandestine marriage. Arbella was James's cousin and a } \\
\text { member of his household. See chapter five. }\end{array}$ \\
\hline James VI/I & 1612 & $\begin{array}{l}\text { Theophilus Howard, } \\
\text { heir to first earl of } \\
\text { Suffolk }\end{array}$ & $\begin{array}{l}\text { Elizabeth } \\
\text { Home }\end{array}$ & $\begin{array}{l}\text { Support; Anglo-Scottish union policy. See Chamberlain, vol. 1, 385; RPC, 1610-1613, 128n; } \\
\text { Griffin, 42-43; Cokayne, ed., vol. 12/1, } 467 \text {. }\end{array}$ \\
\hline James VI/I & 1613 & $\begin{array}{l}\text { Thomas Hamilton, first } \\
\text { lord Binning [S] }\end{array}$ & Julian Kerr & $\begin{array}{l}\text { Support. Kerr was the sister of James's favourite, Somerset. Within two months, Hamilton } \\
\text { was elevated to the Scottish peerage. See Paul, ed., vol. 4, 309-314. }\end{array}$ \\
\hline James VI/I & 1614 & $\begin{array}{l}\text { John Leslie, sixth earl of } \\
\text { Rothes [S] }\end{array}$ & Anne Erskine & $\begin{array}{l}\text { Support; ward's marriage. With his marriage, Rothes became a kinsman of James as Lady } \\
\text { Anne was the daughter of Lady Mary Stewart, countess of Mar, and a cousin of the king. See } \\
\text { HMC, Fourth Report, 509; Paul, ed., vol. 7, 297-299. }\end{array}$ \\
\hline
\end{tabular}


Appendix

\begin{tabular}{|c|c|c|c|c|}
\hline Monarch & $\begin{array}{l}\text { Year of } \\
\text { marriage }\end{array}$ & Male, title & Female & Imputed monarchical involvement: comments/sources \\
\hline James VI/I & 1614 & $\begin{array}{l}\text { Richard Preston, first } \\
\text { baron Dingwall }[\mathrm{S}]\end{array}$ & $\begin{array}{l}\text { Elizabeth } \\
\text { Butler }\end{array}$ & $\begin{array}{l}\text { Support; widow's marriage; Dingwall had served in James's household. James arranged } \\
\text { marriage. See Juhala, 311, 315; Paul, ed., vol. 3, 121-122. }\end{array}$ \\
\hline James VI/I & 1614 & $\begin{array}{l}\text { Robert Boyd, seventh } \\
\text { lord Boyd [S] }\end{array}$ & $\begin{array}{l}\text { Margaret } \\
\text { Montgomerie }\end{array}$ & $\begin{array}{l}\text { Support; royal ward. James permitted Boyd to inherit his lands, despite his minority, just } \\
\text { prior to his wedding. See } R P C, 1613-1616,275-276 ; \text { Paul, ed., vol. 5, 168, } 170 .\end{array}$ \\
\hline James VI/I & 1614 & $\begin{array}{l}\text { Robert Ker, first lord } \\
\text { Roxburghe }[\mathrm{S}]\end{array}$ & $\begin{array}{l}\text { Jean } \\
\text { Drummond }\end{array}$ & $\begin{array}{l}\text { Support; religious policy, interdenominational union; in loco parentis, Roxburghe and } \\
\text { Drummond served in James's and Queen Anne's households, respectively. The king and } \\
\text { queen attended the wedding. See Chamberlain, vol. 1,486, 487, 504; HMC, Mar and Kellie, } \\
\text { vol. 2, 56; CSPD, 1611-1618, 206, 415; Juhala, 326, 329. }\end{array}$ \\
\hline James VI/I & 1616 & $\begin{array}{l}\text { Robert Rich, third baron } \\
\text { Rich }\end{array}$ & Frances Wray & $\begin{array}{l}\text { Support; widow's marriage. As Rich served on the Privy Council, he was well-known to } \\
\text { James. See Cokayne, ed., vol. 12/2, 404-406; ODNB, s.v. "Rich, Robert, first earl of Warwick." }\end{array}$ \\
\hline James VI/I & 1617 & $\begin{array}{l}\text { James Hay, first baron } \\
\text { Hay }\end{array}$ & Lucy Percy & $\begin{array}{l}\text { Support; Anglo-Scottish union policy. James attended the wedding feast. Hay was a close, } \\
\text { loyal servant and favourite of James. See chapter three. }\end{array}$ \\
\hline James VI/I & 1619 & $\begin{array}{l}\text { Robert Maxwell, tenth } \\
\text { lord Maxwell [S] }\end{array}$ & $\begin{array}{l}\text { Elizabeth } \\
\text { Beaumont }\end{array}$ & $\begin{array}{l}\text { Support; Anglo-Scottish union policy. Beaumont was a cousin of James's favourite, George } \\
\text { Villiers, marquess of Buckingham, who may have arranged the marriage. Within one year, } \\
\text { Maxwell was elevated to an earldom. See Paul, ed., vol. 6, 486; ODNB, s.v. "Maxwell, Robert, } \\
\text { first earl of Nithsdale." }\end{array}$ \\
\hline James VI/I & 1620 & $\begin{array}{l}\text { George Villiers, first } \\
\text { marquess of } \\
\text { Buckingham }\end{array}$ & $\begin{array}{l}\text { Katherine } \\
\text { Manners }\end{array}$ & $\begin{array}{l}\text { Support; religious policy, Protestant intra-denominational union; in loco parentis, } \\
\text { Buckingham was a favourite of James's and served in his household. See chapter three. }\end{array}$ \\
\hline James VI/I & 1620 & $\begin{array}{l}\text { Charles Howard, heir to } \\
\text { first earl of Nottingham }\end{array}$ & Mary Cokayne & $\begin{array}{l}\text { Support. Howard's family were supporters of James. Within one year, Howard was named } \\
\text { lord-lieutenant of Surrey. See Cokayne, ed., vol. 9, 788-789. }\end{array}$ \\
\hline James VI/I & 1620 & $\begin{array}{l}\text { Lionel Cranfield, later } \\
\text { first baron Cranfield }\end{array}$ & Anne Brett & $\begin{array}{l}\text { Support. James arranged the marriage, gave Brett away, and offered a dowry. Brett was a } \\
\text { cousin of James's favourite, Buckingham, who likely played a part in organising the match. } \\
\text { See } O D N B \text {, s.v. "Cranfield, Lionel, first earl of Middlesex." }\end{array}$ \\
\hline James VI/I & 1621 & $\begin{array}{l}\text { Ludovick Stuart, second } \\
\text { duke of Lennox [S] and } \\
\text { earl of Richmond }\end{array}$ & $\begin{array}{l}\text { Frances } \\
\text { Howard }\end{array}$ & $\begin{array}{l}\text { Support; clandestine marriage; Anglo-Scottish union policy; widow's marriage. See } \\
\text { Chamberlain, vol. 2, 375-376; Paul, ed., vol. 5, } 357 .\end{array}$ \\
\hline James VI/I & 1621 & $\begin{array}{l}\text { Thomas Erskine, first } \\
\text { earl of Kellie [S] }\end{array}$ & Dorothy Smith & $\begin{array}{l}\text { Support; Anglo-Scottish union policy. Kellie had been a member of James's household. See } \\
\text { Juhala, 311; Paul, ed., vol. 5, 86; Carlisle, 99; ODNB, s.v. "Erskine, Thomas, first earl of Kellie." }\end{array}$ \\
\hline
\end{tabular}


Royal Opportunity

\begin{tabular}{|c|c|c|c|c|}
\hline Monarch & $\begin{array}{l}\text { Year of } \\
\text { marriage }\end{array}$ & Male, title & Female & Imputed monarchical involvement: comments/sources \\
\hline James VI/I & 1621 & $\begin{array}{l}\text { John Mordaunt, fifth } \\
\text { baron Mordaunt }\end{array}$ & $\begin{array}{l}\text { Elizabeth } \\
\text { Howard, fourth } \\
\text { de jure, suo jure } \\
\text { baroness Saint } \\
\text { John of Bletso }\end{array}$ & $\begin{array}{l}\text { Support; religious policy, Protestant intra-denominational union; ward's marriage (Mordaunt } \\
\text { was a royal ward). Following his father's involvement in the Gunpowder Plot, James placed } \\
\text { Mordaunt under the guardianship of Archbishop Abbot. Mordaunt, an ally of Buckingham, } \\
\text { converted to Protestantism prior to his wedding. See Chamberlain, vol. 2, 349, 361; ODNB, } \\
\text { s.v. "Mordaunt, Henry, second earl of Peterborough." }\end{array}$ \\
\hline James VI/I & 1622 & $\begin{array}{l}\text { James Hamilton, heir to } \\
\text { second marquess of } \\
\text { Hamilton [S] }\end{array}$ & Mary Feilding & $\begin{array}{l}\text { Support; Anglo-Scottish union policy. Hamilton was James's cousin. James attended the } \\
\text { wedding which was likely arranged by Feilding's uncle, Buckingham. See TNA, SP } \\
\text { 14/131/69; ODNB, s.v. "Hamilton, James, first duke of Hamilton." }\end{array}$ \\
\hline James VI/I & 1622 & $\begin{array}{l}\text { John Kennedy, sixth earl } \\
\text { of Cassillis [S] }\end{array}$ & Jean Hamilton & $\begin{array}{l}\text { Support; ward's marriage (Cassillis was a royal ward). The wedding took place at Whitehall. } \\
\text { See Paul, ed., vol. 2, 478; ODNB, s.v. "Kennedy, John, sixth earl of Cassillis." }\end{array}$ \\
\hline James VI/I & 1622 & $\begin{array}{l}\text { James Home, second } \\
\text { earl of Home [S] }\end{array}$ & $\begin{array}{l}\text { Katherine } \\
\text { Carey }\end{array}$ & $\begin{array}{l}\text { Support; Anglo-Scottish union policy; ward's marriage (Home was a royal ward). James } \\
\text { arranged the marriage. See Brown, Noble Society, 124; Paul, ed., vol. 4, } 467 .\end{array}$ \\
\hline James VI/I & 1622 & $\begin{array}{l}\text { Thomas Hamilton, heir } \\
\text { to earl of Melrose and } \\
\text { first earl of Haddington } \\
\text { [S] }\end{array}$ & $\begin{array}{l}\text { Katherine } \\
\text { Erskine }\end{array}$ & $\begin{array}{l}\text { Non-participation. James may not have approved of this union of two of Scotland's most } \\
\text { powerful families. See Paul, ed., vol. 4,316; ODNB, s.v. "Hamilton, Thomas, second earl of } \\
\text { Haddington." }\end{array}$ \\
\hline James VI/I & 1622 & $\begin{array}{l}\text { Christopher Villiers, } \\
\text { later first earl of } \\
\text { Anglesey [W] }\end{array}$ & $\begin{array}{l}\text { Elizabeth } \\
\text { Sheldon }\end{array}$ & $\begin{array}{l}\text { Support; in loco parentis, Villiers served in James's household and was the brother of } \\
\text { Buckingham, the king's favourite, who may have been involved in arranging the marriage. } \\
\text { Within one year, Villiers was elevated to the peerage. See Cokayne, ed., vol. 1, 132; ODNB, s.v. } \\
\text { "Villiers, Christopher, first earl of Anglesey." }\end{array}$ \\
\hline James VI/I & 1622 & Edward Wray & $\begin{array}{l}\text { Elizabeth } \\
\text { Norris, third } \\
\text { suojure } \\
\text { baroness } \\
\text { Norris }\end{array}$ & $\begin{array}{l}\text { Opposition; clandestine marriage; in loco parentis, Wray served in James's household. } \\
\text { Baroness Norris was due to marry Buckingham's brother, Christopher Villiers. Following the } \\
\text { wedding, Wray was removed from his bedchamber position and imprisoned in the Tower. } \\
\text { The couple were later tried in the Star Chamber. See Chamberlain, vol. 2, 334, 395, 423, 429; } \\
\text { Cokayne, ed., vol. 9, 648n. }\end{array}$ \\
\hline James VI/I & 1624 & $\begin{array}{l}\text { John Hay, eighth lord } \\
\text { Hay }[\mathrm{S}]\end{array}$ & Jean Seton & $\begin{array}{l}\text { Support. Within one year, Hay was appointed commander of the middle shires and served in } \\
\text { other capacities before and after his wedding. See Paul, ed., vol. 8, 449; Cokayne, ed., vol. } \\
12 / 2,71-74 \text {. }\end{array}$ \\
\hline
\end{tabular}




\section{Bibliography}

\section{Unpublished Sources}

\section{Manuscript Sources}

British Library, London

Cotton Manuscripts

Caligula, Titus

Harley Manuscripts

289

Lansdowne Manuscripts

Volumes

$5,12,18,34$

Cecil Papers, Hatfield House, Hertfordshire, UK

Petitions

1301,2368

Volumes

$11,23,109,147,148,153,156,158,160,168,169$,

$170,186,188,201,203,242,284$

Folger Shakespeare Library, Washington, D. C.

Cavendish-Talbot Manuscripts

L.a.97, L.b.338, X.d.428

The National Archives, Kew, London

State Papers

Domestic

$12,14,15$

Scotland

$52,53,59$

Foreign

69,70

\section{Ph.D. Theses}

Grant, Ruth. "George Gordon, Sixth Earl of Huntly and the Politics of the Counter-Reformation in Scotland, 1581-1595." Ph.D. diss., University of Edinburgh, 2010.

Juhala, Amy. "The Household and Court of King James VI of Scotland, 1567-1603." Ph.D. diss., University of Edinburgh, 2000.

Macpherson, Robin. "Francis Stewart, 5th earl Bothwell, c 1562-1612: Lordship and Politics in Jacobean Scotland." Ph.D. diss., University of Edinburgh, 1998.

Merton, Charlotte. "The Women Who Served Queen Mary and Queen Elizabeth: Gentlewomen and Maids of the Privy Chamber, 1553-1603." Ph.D. diss., University of Cambridge, 1992. 


\section{Published Sources}

\section{Primary}

Abbot, George. The Kings Maiesties Letter to the Lords Grace of Canterbury, Touching Preaching, and Preachers. London: s.n., 1622. EEBO.

Acts of the Privy Council of England. New series. Edited by John Roche Dasent. Vols. 7-39 (15581625). London: H. M. Stationery Office, 1893-1933. MEMSO.

Allen, William, and Robert Parsons [R. Doleman]. A Conference about the Next Succession to the Crowne of Ingland Diuided into Tvvo Partes. Antwerp: A. Conincx, 1595. EEBO.

Anonymous. A Short Historical Account Touching the Succession of the Crown. London: Richard Baldwin, 1689. EEBO.

-----. The Institution of a Christen Man. London: Thomas Berthelet, 1537. EEBO.

-----. The Lamentacion that Ladie Iane Made Saiyng for my Fathers Proclamacion Now Must I Lese My Heade. London: [By J. Kingston] for Ihon Wight, 1562. EEBO.

----. The Order of Matrimony. London: Anthony Scoloker, 1549. EEBO.

-----. The True Lovers Knot Untied, Being the Right Path Whereby to Advise Princely Vergins How to Behave Themselves, By the Example of the Renowned Princess, the Lady Arabella, and the Second Son of the Lord Seymore, Late Earl of Hartfort. London: Printed by and for A. M., [between 1695-1700]. EEBO.

Aristotle. Nicomachean Ethics. Translated by H. Rackham. Cambridge: Harvard University Press, 1926. Digital Loeb Classical Library.

Aylmer, John. An Harborovve for Faithfull and Trevve Subiectes agaynst the Late Blowne Blaste, concerninge the Gouernme[n]t of VVemen. London: Printed by John Day, 1559. EEBO.

Bacon, Francis. A Brief Discourse, Touching the Happie Vnion of the Kingdomes of England, and Scotland. London: Printed [by R. Read] for Fœlix Norton, 1603. EEBO.

----. An Essay of a King. London: Printed for Richard Best, 1642. EEBO.

Baildon, William Paley, ed. Les Reportes del Cases in Camera Stellata 1593-1609: From the Original Manuscripts of John Hawarde of the Inner Temple. [London]: Privately Printed, 1894. Internet Archive.

Bannatyne Club. The Bannatyne Miscellany; Containing Original Papers and Tracts, Chiefly Relating to the History and Literature of Scotland. Vol. 1. Edinburgh: The Bannatyne Club, 1827. Internet Archive.

Becon, Thomas. The Worckes of Thomas Becon Whiche He Hath Hitherto Made and Published. Vol. 1. London: John Day, 1564. EEBO.

Birch, Thomas, ed. Memoirs of the Reign of Queen Elizabeth from the Year 1581 till her Death. 2 vols. London: A. Millar, 1754. Internet Archive.

Birch, Thomas, and Robert Folkestone Williams, eds. The Court and Times of James the First; Illustrated by Authentic and Confidential Letters, from Various Public and Private Collections. 2 vols. London: Henry Colburn, 1848. Internet Archive.

Bodin, Jean. Six Books of the Commonwealth. Abridged and translated by M. J. Tooley. 1955. Reprint, Oxford: Basil Blackwell, 1967. Liberty Library of Constitutional Classics.

Botero, Giovanni. The Reason of State. Edited by Robert Bireley. Cambridge: Cambridge University Press, 2017.

British Library. "Broadside Ballad “The True Lovers Knot Untied.”' Accessed 13 November 2019. https://www.bl.uk/collectionitems/ /link.aspx? id=8307A9EF6EBF4F50A5ED1604696A64D7\& z=z.

Brown, K. M., et al., eds. The Records of the Parliaments of Scotland to 1707. Online ed. St. Andrews: University of St. Andrews Press, 2007-2020. http://www.rps.ac.uk/.

Bullinger, Heinrich. The Christen State of Matrimonye. London: Nycholas Hyll for John Wayght, 1552. EEBO.

----. The Golden Boke of Christen Matrimonye Moost Necessary [and] Profitable for All The[m], that Entend to Liue Quietly and Godlye in the Christen State of Holy Wedlock. Translated by Miles Coverdale. London: Ioh[a]n Mayler for Ioh[a]n Gough, 1542. EEBO. 
Calendar of Documents Relating to Scotland Preserved in Her Majesty's Public Record Office, London. Edited by Joseph Bain. Vol. 4 (1357-1509). Edinburgh: H. M. General Register House, 1888. MEMSO.

Calendar of the Letters and Papers Relating to the Affairs of the Borders of England and Scotland Preserved in her Majesty's Public Record Office London. Edited by Joseph Bain. 2 vols. (15601603). Edinburgh: H. M. General Register House, 1894-1896. MEMSO.

Calendar of Letters and State Papers Relating to English Affairs, Preserved Principally in the Archives of Simancas. Edited by Martin A. S. Hume. Vols. 14-17 (1558-1603). London: Eyre and Spottiswoode, 1892-1899. MEMSO.

Calendar of State Papers and Manuscripts, Relating to English Affairs. Existing in the Archives and Collections of Venice, and in Other Libraries of Northern Italy. Edited by Rawdon Brown, G. Cavendish Bentinck, Horatio F. Brown, and Allen B. Hinds. Vols. 7-18. London: H. M. Stationery Office, 1890-1912. MEMSO.

Calendar of State Papers, Domestic Series, of the Reigns of Edward VI., Mary, Elizabeth, and James I, Preserved in the State Paper Department and H. M. Public Record Office. Edited by Robert Lemon and Mary Anne Everett Green. 12 vols. London: Longman, 1856-1872. MEMSO.

Calendar of State Papers, Foreign Series, of the Reign of Elizabeth, Preserved in the Public Record Office. Edited by Joseph Stevenson, Allan James Crosby, Arthur John Butler, Sophie Crawford Lomas, Allen B. Hines, and Richard Bruce Wernham. 26 vols. (1553-1588). London: H. M. Stationery Office, 1863-1936. MEMSO.

Calendar of State Papers, Relating to English Affairs, Preserved Principally at Rome, in the Vatican Archives and Library. Edited by J. M. Rigg. Vols. 1-2 (1558-1578). London: H. M. Stationery Office, 1916-1926. MEMSO.

Calendar of State Papers Relating to Ireland, of the Reign of James I. Edited by C. W. Russell and John P. Prendergast. Vol. 12 (1606-1608). London: H. M. Stationery Office, 1874. MEMSO.

Calendar of the Clarendon State Papers Preserved in the Bodleian Library. Edited by O. Ogle, W. H. Bliss, and H. O. Coke. Vol. 1 (1523-1649). Oxford: Clarendon Press, 1872. MEMSO.

Calendar of the Patent Rolls Preserved in the Public Record Office, Elizabeth I. Edited by Margaret Post and Ann E. Morton. Vols. 1-9 (1558-1582). London: H. M. Stationery Office, 1939-1986. HathiTrust.

Calendar of the State Papers Relating to Scotland and Mary, Queen of Scots 1547-1603. Preserved in the Public Record Office, the British Museum, and Elsewhere in England. Edited by Joseph Bain, William K. Boyd, Henry W. Meikle, Annie I. Cameron, M. S. Giuseppi, and J. D. Mackie. Vols. 113/1 (1547-1603). Edinburgh and Glasgow: H. M. General Register House and H. M Stationery Office, 1898-1969. MEMSO.

Calendar of the State Papers Relating to Scotland, Preserved in the State Paper Department of Her Majesty's Public Record Office, 1509-1603. Edited by Markham John Thorpe. 2 vols. London: Longman, Brown, Green, Longmans, \& Roberts, 1858. Internet Archive.

Camden, William. Annales: The True and Royall History of the Famous Empresse Elizabeth, Queene of England, France and Ireland \&c. London: Printed for Benjamin Fisher, 1625. Internet Archive.

-----. The History of the Most Renowned and Victorious Princess Elizabeth, Late Queen of England; Containing All the Most Important and Remarkable Passages of State, Both at Home and Abroad (so far as they were linked with English Affairs) During her Long and Prosperous Reign. $4^{\text {th }}$ ed. London: Printed by M. Flesher, for R. Bentley, 1688. EEBO.

Campion, Thomas. The Works of Thomas Campion. Edited by Walter R. Davis. London: Faber and Faber, 1969.

Cawdry, Robert. A Table Alphabeticall Conteyning and Teaching the True Writing, and Vnderstanding of Hard Vsuall English Words, Borrowed from the Hebrew, Greeke, Latine, or French, \&c. London: Printed by I. R[oberts] for Edmund Weauer, 1604. EEBO.

Chamberlain, John. The Letters of John Chamberlain. Edited by Norman Egbert McClure. 2 vols. 1939. Reprint, Philadelphia: The American Philosophical Society, 1962. HathiTrust.

Church of England. The Anglican Canons, 1529-1947. Edited by Gerald Bray. Woodbridge: Boydell and Brewer, 1998.

-----. Articles Devised by the Kinges Hyghnes Maiestie to Stablyshe Christen Quietnes and Vnitie Amonge Vs. London: Thomas Berthelet, 1536. EEBO. 
-----. Constitutions and Canons Ecclesiastical. London: John Bill and Christopher Barker, 1676. EEBO. Church of Scotland. The First and Second Booke of Discipline Together with Some Acts of the Generall Assemblies, Clearing and Confirming the Same: and an Act of Parliament. Amsterdam: G. Thorp, 1621. EEBO.

Collier, J. Payne, ed. The Egerton Papers: A Collection of Public and Private Documents, Chiefly Illustrative of the Times of Elizabeth and James I. Camden Society. London: John Bowyer Nichols and Son ,1840. MEMSO.

Coke, Edward, Sir. The Reports of Sir Edward Coke, Knt. New ed. Edited by John Henry Thomas and John Farquhar Fraser. Vols. 3, 4, 6. London: John Butterworth and Son, 1826. Google Books.

Cornwallis, Jane, Lady. The Private Correspondence of Jane Lady Cornwallis, 1613-1644. Edited by Richard Griffin, Baron Braybrooke. London: S. \& J. Bentley, Wilson, \& Fley, 1842. Internet Archive.

Cornwallis, William, Sir. The Miraculous and Happie Vnion of England \& Scotland. Edinburgh: Printed by Thomas Finlason, 1604. EEBO.

Coverdale, Miles, ed., Certain Most Godly, Fruitful, and Comfortable Letters. London: By Iohn Day, 1564. EEBO.

Cowell, John. The Interpreter: or Booke Containing the Signification of Words. Cambridge: John Legate, 1607. Internet Archive.

Cressy, David, and Lori Anne Ferrell, eds. Religion and Society in Early Modern England: A Sourcebook. 2nd ed. New York and London: Routledge, 2005.

D'Ewes, Simonds. The Journals of All the Parliaments During the Reign of Queen Elizabeth, Both of the House of Lords and House of Commons. London: Printed for John Starkey, 1682. Google Books.

Elizabeth I. Elizabeth I: Collected Works. Edited by Leah Marcus, Janel Mueller, and Mary Beth Rose. Chicago and London: University of Chicago Press, 2000.

-----. The Letters of Queen Elizabeth I. Edited by G. B. Harrison. London: Cassell \& Company Ltd., 1968.

Elizabeth I and James VI. Letters of Queen Elizabeth and James VI of Scotland. Edited by John Bruce. Camden Society. London: J. B. Nichols and Son, 1849. MEMSO.

Elton, G. R., ed. The Tudor Constitution: Documents and Commentary. $2^{\text {nd }}$ ed. Cambridge: Cambridge University Press, 1982.

Foley, Henry, ed. Records of the English Province of the Society of Jesus. Vols. 3-4. London: Burns and Oates, 1878. HathiTrust.

Fortescue, John, Sir. The Governance of England: Otherwise called the Difference between an Absolute and a Limited Monarchy. Edited by Charles Plummer. Oxford: Clarendon Press, 1885. Internet Archive.

Fuller, Nicholas. The Argument of Nicholas Fuller of Grayes Inne Esquire, in the Case of Tho. Lad, and Rich Mansell his Clients. London: Printed for V. Vavasour, 1641. EEBO.

Galloway, Bruce R., and Brian P. Levack, eds. The Jacobean Union: Six Tracts of 1604. Edinburgh: C. Constable, 1985.

Golding, Arthur. The VVoorke of the Excellent Philosopher Lucius Annæus Seneca Concerning Benefyting That is Too Say the Dooing, Receyuing, and Requyting of Good Turnes. London: By [John Kingston for] Iohn Day, 1578. EEBO.

Goldring, Elizabeth, Faith Eales, Elizabeth Clarke, and Jayne Elisabeth Archer, eds. John Nichols's The Progresses and Public Processions of Queen Elizabeth I. New ed. 5 vols. Oxford: Oxford University Press, 2014.

Gonzalez, Tomás. Documents from Simancas Relating to the Reign of Elizabeth, 1558-1568. Edited and translated by Spencer Hall. London: Chapman and Hall, 1865. HathiTrust.

Gordon, John. The Vnion of Great Britaine By Iohn Gordon Deane of Salisburie. London: Printed [by G. Eld] for William Aspley, 1604. EEBO.

Great Britain. The Statutes of the Realm. Edited by A. Luders, T. E. Tomlins, and J. Caley. Vols. 1-4. London: s.n., 1810-1828. The Making of the Modern World.

Hales, John. "A Declaration of the Succession of the Crowne Imperiall of Ingland, made by J. Hales, 1563." In The Hereditary Right of the Crown of England Asserted (Appendix Numb. 7). Edited by George Harbin, xx-xlii. London: Printed by G. James, for Richard Smith, 1713. ECCO. 
Harington, John, Sir. A Tract on the Succession to the Crown. Edited by Clements R. Markham. Roxburghe Club. London: J. B. Nichols and Sons, 1880. Internet Archive.

----.. Nugæ Antiquæ: Being a Miscellaneous Collection of Original Papers, in Prose and Verse; Written during the Reigns of Henry VIII, Edward VI, Queen Mary, Elizabeth, and King James. Edited by Henry Harington. Vol. 1. London: Vernor and Hood, 1804. Internet Archive.

Hartley, T. E., ed. Proceedings in the Parliaments of Elizabeth I. 3 vols. London and New York: Leicester University Press, 1981-1995.

Haward, Nicholas. The Line of Liberalitie Dulie Directinge the Wel Bestowing of Benefites and Reprehending the Comonly Vsed Vice of Ingratitude. London: Thomas Marshe, [1569]. EEBO.

Henrisoun [Harrison], James. An Exhortacion to the Scottes to Conforme Them Selfes to the Honorable, Expedie[n]t, and Godly Vnion, Betwene the Twoo Realmes of Englande and Scotlande. London: Richard Grafton, 1547. EEBO.

Historical Manuscripts Commission. Calendar of the Manuscripts of Lord Sackville. Edited by A. P. Newton and F. J. Fisher. 2 vols. (1551-1612). London: H. M. Stationery Office, 1940-1966. MEMSO.

-----. Calendar of the Manuscripts of the Most Honourable the Marquis of Salisbury, K. G., Preserved at Hatfield House, Hertfordshire. Edited by M. S. Giuseppi, and D. McN. Lockie. Vols. 1-19 (13061607). London: H. M. Stationery Office, 1883-1965. MEMSO.

----. Eleventh Report of the Royal Commission on Historical Manuscripts, Appendix, Part I. The Manuscripts of Henry Duncan Skrine, Esq. (Salvetti Correspondence). London: H. M. Stationery Office, 1887. MEMSO.

-----. Fifth Report of the Royal Commission on Historical Manuscripts. London: Printed by George Edward Eyre and William Spottiswoode, for H. M. Stationery Office, 1876. MEMSO.

----. Fourth Report of the Royal Commission on Historical Manuscripts. Part I. Report and Appendix. London: George Edward Eyre and William Spottiswoode, 1874. MEMSO.

-----. Report on Manuscripts in Various Collections. Vol. 2, The Manuscripts of Sir George Wombwell, The Duke of Norfolk, Lord Edmund Talbot, Miss Buxton, Mrs. Harford and Mrs. Wentworth of Woolley. London: H. M. Stationery Office, 1903. MEMSO.

-----. Report on the Laing Manuscripts Preserved in the University of Edinburgh. Vol. 1 (1287-1699). London: H. M. Stationery Office, 1914. MEMSO.

-----. Report on the Manuscripts of Lord Middleton, Preserved at Wollaton Hall, Nottinghamshire. London: H. M. Stationery Office, 1911. MEMSO.

----. Report on the Manuscripts of the Duke of Buccleuch and Queensbery, Preserved at Montagu House, Whitehall. Vol. 1 (1438-1778). London: Printed for H. M. Stationery Office by Eyre and Spottiswoode, 1899. MEMSO.

-----. Report on the Manuscripts of the Earl of Mar and Kellie Preserved at Alloa House, Clackmannanshire. Edited by Henry Paton. 2 vols. London: H. M. Stationery Office, 19041930. MEMSO.

-----. Report on the Manuscripts of the Marquess of Downshire Preserved at Easthampstead Park, Berks. Vol. 2, Papers of William Trumbull the Elder 1605-1610. Edited by E. K. Purnell and A. B. Hinds. London: H. M. Stationery Office, 1936. MEMSO.

-----. Report on the Manuscripts of the Late Reginald Rawdon Hastings, Esq., of the Manor House Ashby de la Zouche. Edited by Francis Bickley. Vols. 1-2. London: H. M. Stationery Office, 19281930. MEMSO.

-----. Tenth Report, Appendix, Part IV. The Manuscripts of the Earl of Westmorland, Captain Stewart, Lord Stafford, Lord Muncaster, and Others. London: Eyre and Spottiswoode, 1885. MEMSO.

-----. The Manuscripts of His Grace the Duke of Portland, Preserved at Welbeck Abbey. Vol. 9 (15971714). London: H. M. Stationery Office, 1923. MEMSO.

-----. The Manuscripts of the Most Honourable the Marquess of Bath, Preserved at Longleat, Wiltshire. Vols. 4-5. Edited by Marjorie Blatcher and G. Dyfnallt Owen. London: H. M. Stationery Office, 1968-1980. Internet Archive.

----. Twelfth Report, Appendix, Part IV. The Manuscripts of His Grace the Duke of Rutland, G.C.B., Preserved at Belvoir Castle. Vols. 1-2. London: H. M. Stationery Office, 1888-1889. MEMSO.

Holinshed, Raphael. Chronicles of England, Scotland, and Ireland. Edited by Henry Ellis. Vol. 4. London: J. Johnson, 1807-1808. HathiTrust. 
Howard, Leonard. A Collection of Letters, From the Original Manuscripts of Many Princes, Great Personages and Statesmen. London: Printed for the Author, 1753. HathiTrust.

Howell, T. B., ed. Cobbett's Complete Collection of State Trials and Proceedings for High Treason and Other Crimes and Misdemeanors. Vols. 1-2 (1163-1627). London: R. Bagshaw, 1809. HathiTrust.

Humphrey, Laurence. The Nobles, or of Nobilitye, The Original Nature, Dutyes, Right and Christian Institucion Thereof. London: By Thomas Marshe, 1563. EEBO.

James VI and I. King James VI and I: Political Writings. Edited by Johann P. Sommerville. Cambridge: Cambridge University Press, 1994.

-----. Letters of King James VI and I. Edited by G. P. V. Akrigg. Berkeley, CA: University of California Press, 1984.

-----. The Prince's Cabala: Or Mysteries of State. London: Printed for R. Smith et al., 1715. Internet Archive.

Jonson, Ben. Ben Jonson: The Complete Masques. Edited by Stephen Orgel. New Haven and London: Yale University Press, 1969.

----. Hymenæi: or The Solemnities of Masque, and Barriers. London: Valentine Sims for Thomas Thorp, 1606. EEBO.

Journals of the House of Commons. Vol. 1 (1547-1628). London: H. M. Stationery Office, 1802. MEMSO.

Journals of the House of Lords. Vols. 1-3 (1509-1628). London: H. M. Stationery Office, 1767-1830. HathiTrust.

Kenyon, J. P., ed. The Stuart Constitution 1603-1688: Documents and Commentary. $2^{\text {nd }}$ ed. Cambridge: Cambridge University Press, 1986.

Knowler, William, ed. The Earl of Strafforde's Letters and Dispatches, With an Essay towards His Life by Sir George Radcliffe. Vol. 2. London: William Bowyer, 1739. Google Books.

Knox, John. The First Blast of the Trumpet Against the Monstrous Regiment of Women. 1558. Reprint, New York: Da Capo Press, 1972.

Larkin, James F. and Paul L. Hughes, eds. Stuart Royal Proclamations. Vol. 1. Oxford: Clarendon Press, 1973.

Lettenhove, M. Le Baron Kervyn de. Relations Politiques Des Pays-Bas et de L'Angleterre, Sous le Règne de Philippe II. Vol. 2. Brussels: F Hayez, 1882. Internet Archive.

Letters and Papers, Foreign and Domestic, of the Reign of Henry VIII. Preserved in the Public Record Office, the British Museum, and Elsewhere in England. Edited by James Gairdner and R. H. Brodie. Vol. 18/1 (1543). London: H. M. Stationery Office, 1901. MEMSO.

Lodge, Edmund. Illustrations of British History, Biography, and Manners: In the Reigns of Henry VIII, Edward VI, Mary, Elizabeth, \& James I. Vol. 3. London: Sold by G. Nicol, 1791. HathiTrust.

-----. Illustrations of British History, Biography, and Manners: In the Reigns of Henry VIII, Edward VI, Mary, Elizabeth, \& James I. $2^{\text {nd }}$ ed. 3 vols. London: John Chidley, 1838. Internet Archive.

Lodge, Thomas. The Workes of Lucius Annæus Seneca, Both Morrall and Naturall. London: Printed by William Stansby, 1614. EEBO.

Machiavelli, Niccolò. The Prince. Translated by George Bull. Harmondsworth: Penguin Books, 1961.

Machyn, Henry. The Diary of Henry Machyn, Citizen and Merchant-Taylor of London, from AD 1550 to AD 1563. Edited by John Gough Nichols. Camden Society. 1848. Reprint, New York and London: AMS Press, 1968. Internet Archive.

Macray, W. D., ed. Beaumont Papers. Letters Relating to the Family of Beaumont of Whitley, Yorkshire. Roxburghe Club. London: Nichols and Sons, 1884. Internet Archive.

Macrobius, Ambrosius Aurelius Theodosius. Commentary on the Dream of Scipio. Translated by William Harris Stahl. New York: Columbia University Press, 1990.

Maidment, James, ed. Letters and State Papers During the Reign of King James the Sixth, Chiefly from the Manuscript Collections of Sir James Balfour of Denmyln. Abbotsford Club. Edinburgh: Edinburgh Printing Company, 1838. Internet Archive.

Mair [Major], John. A History of Greater Britain as well England as Scotland. Translated and edited by Archibald Constable. Edinburgh: Printed at the University Press for T. and A. Constable, 1892. Internet Archive. 
Mayer, Jean-Christophe, ed. Breaking the Silence on the Succession: A Sourcebook of Manuscripts \& Rare Elizabethan Texts (c. 1587-1603). Astraea Collection, No. 1. Montpellier: Université Paul-Valéry Montpellier, 2003.

Moysie, David. Memoirs of the Affairs of Scotland. 1577-1603, From Early Manuscripts. Edited by James Dennistoun. Edinburgh: The Bannatyne Club, 1830. Internet Archive.

Munday, Anthony. A VVatch-vvoorde to Englande to Beware of Traytours and Tretcherous Practises. London: Printed [by John Charlewood] for Thomas Hacket, 1584. EEBO.

Nettesheim, Heinrich Cornelius Agrippa von. The Commendation of Matrimony. Translated by David Clapam. London: Thomas Bertheleti, 1540. EEBO.

Nichols, John. The Progresses and Public Processions of Queen Elizabeth. 3 Vols. 1823. Reprint, New York: AMS Press, 1969. HathiTrust.

-----. The Progresses, Processions, and Magnificent Festivities, of King James the First. 4 Vols. 1828. Reprint, New York: AMS Press, 1968. HathiTrust.

Norton, Thomas, and Thomas Sackville. The Tragedie of Gorboduc. London: William Griffith, 1565. EEBO.

Parker, Matthew. Correspondence of Matthew Parker, D.D., Archbishop of Canterbury. Edited by John Bruce and Thomas Perowne. Parker Society. Cambridge: Cambridge University Press, 1853. Internet Archive.

Pepys, Samuel. Diary of Samuel Pepys. Edited by J. Smith. Vol 1. London: J. M. Dent \& Sons Ltd, 1908. HathiTrust.

Plotinus. Enneads. Translated by A. H. Armstrong. Vol. 5. Cambridge: Harvard University Press, 1984. Digital Loeb Classical Library.

Raleigh, Walter, Sir. The Prerogative of Parliaments in England. Midleburghe: s.n., 1628. Internet Archive.

Rimbault, Edward F., ed. The Old Cheque Book, or Book of Remembrance, of the Chapel Royal, from 1561 to 1744. Camden Society. Westminster: J. B. Nichols and Sons, 1872. Internet Archive.

Salignac, Bertrand de, Seigneur de La Mothe Fénélon. Correspondance Diplomatique de Bertrand de Salignac de La Mothe Fénélon, Ambassadeur de France en Angleterre de 1568 à 1575. Edited by C. P. Cooper. Vols. 4, 6. Paris and London: s.n., 1838-1840. Bibliothèque de Nationale de France.

Scott, Thomas. The Belgicke Pismire Stinging the Slothfull Sleeper. London: s.n., 1622. EEBO.

Seneca. Moral Essays. Vol. 3 (De Beneficiis). Cambridge: Harvard University Press, 1935. Digital Loeb Classical Library.

Seymour, Edward, Duke of Somerset. An Epistle or Exhortacion, to Vnitie [and] Peace. London: Richard Grafton, 1548. EEBO.

Sidney, Henry, Sir. Letters and Memorials of State in the Reigns of Queen Mary, Queen Elizabeth, King James, King Charles the First, Part of the Reign of King Charles the Second, and Oliver's Usurpation, Written and Collected By Sir Henry Sydney. Edited by Arthur Collins. 2 vols. London: Printed for T. Osborne, 1746. HathiTrust.

Skene John. Regiam Majestatem: The Auld Lawes and Constitutions of Scotland. Edinburgh: Printed for John Wood, 1774. HeinOnline.Skinner, John, Sir. Rapta Tatio, The Mirruor of his Majesties Present Government, Tending to the Union of his Whole Iland of Brittonie Martiall. London: Printed by W. W[hite] for S. Waterson, 1604. EEBO.

Smith, Thomas, Sir. De Republica Anglorum: A Discourse on the Commonwealth of England. Edited by Mary Dewar. Cambridge and New York: Cambridge University Press, 1982.

Staunford, William, Sir. An Exposicion of the Kinges Prerogative. London: Richard Tottel, 1567. EEBO.

Stevenson, Joseph, ed. Selections from Unpublished Manuscripts in the College Arms and the British Museum Illustrating the Reign of Mary Queen of Scotland, 1543-1568. Maitland Club. Glasgow: s.n., 1837. Google Books.

Stow, John. The Annales of England. London: [By Peter Short, Felix Kingston, and George Eld] for George Bishop, and Thomas Adams, 1605. EEBO.

Strype, John. Annals of the Reformation and Establishment of Religion. New ed. Vols. 1-2. Oxford: Clarendon Press, 1824. HathiTrust.

-----. Ecclesiastical Memorials: Relating Chiefly to Religion, and Its Reformation, Under the Reigns of King Henry VIII, King Edward VI, and Queen Mary the First. Vol. 5. London: Printed for Samuel Bagster, 1816. HathiTrust. 
Stuart, Arbella, Lady. The Letters of Lady Arbella Stuart. Edited by Sara Jayne Steen. Oxford and New York: Oxford University Press, 1994.

Stubbes, John. The Discouerie of a Gaping Gulf Vvhereinto England is Like to be Swallovved by another French Mariage. London: H. Singleton for W. Page, 1579. EEBO.

Tanner, J. R. Constitutional Documents of the Reign of James I, A.D. 1603-1625. 1930. Reprint, Cambridge: Cambridge University Press, 1961.

The Exchequer Rolls of Scotland [Rotuli Scaccarii Regum Scotorum]. Edited by George Powell M'Neill. Vol. 21 (1580-1588). Edinburgh: H. M. General Register House, 1901. MEMSO.

The Register of the Great Seal of Scotland [Registrum Magni Sigilli Regum Scotorum]. Edited by John Maitland Thomson. Vols. 4-8 (1546-1633). Edinburgh: H. M. General Register House, 18861894. HathiTrust.

The Register of the Privy Council of Scotland. Vols. 4-13 (1585-1625). Edited and abridged by David Masson. Edinburgh: H. M. General Register House, 1881-1896. MEMSO.

Webster, John. The Tragedy of the Dutchesse of Malfy As it was Presented Priuatly, at the Black-Friers; and Publiquely at the Globe, by the Kings Maiesties Seruants. London: Printed by Nicholas Okes, for Iohn Waterson, 1623. EEBO.

Wentworth, Peter. A Pithie Exhortation to her Maiestie for Establishing her Successor to the Crowne. Edinburgh: Imprinted by Robert Waldegrave, 1598. EEBO.

Whately, William. A Bride-Bush: or, A Direction for Married Persons Plainely Describing the Duties Common to Both, and Peculiar to Each of Them. London: Felix Kyngston, 1619. EEBO.

-----. A Care-cloth: or A Treatise of the Cumbers and Troubles of Marriage Intended to Aduise Them that May, to Shun them; That May Not, Well and Patiently to Beare Them. London: Felix Kyngston, 1624. EEBO.

Winwood, Ralph, Sir. Memorials of State in the Reigns of Q. Elizabeth and K. James I. 3 vols. Edited by Edmund Sawyer. London: Printed by W. B. for T. Ward, 1725. Internet Archive.

Wotton, Henry, Sir. The Life and Letters of Sir Henry Wotton. Edited by Logan Pearsall Smith. Vol. 1. Oxford: Clarendon Press, 1907. Internet Archive.

Wright, Thomas, ed. Queen Elizabeth and Her Times. 2 vols. London: Henry Colburn, Publisher, 1838. Internet Archive.

Yorke, Philip, Earl of Hardwicke, ed. Miscellaneous State Papers, 1501-1726. Vol. 1. London: Printed for W. Strahan and T. Cadell, 1778. Internet Archive.

\section{Secondary}

A Dictionary of Law. Edited by Jonathan Law. 9th ed. Oxford: Oxford University Press, 2018.

Adams, Simon. "Because I am of that Countrye \& Mynde to Plant Myself There': Robert Dudley, Earl of Leicester and the West Midlands." Midland History 20 (1995): 21-74.

----. "The Succession and Foreign Policy." History Today 53 (2003): 42-48.

Alford, Stephen. The Early Elizabethan Polity: William Cecil and the British Succession Crisis, 15581569. New York: Cambridge University Press, 1998.

Anderson, Mark. "Shakespeare" by Another Name: The Life of Edward de Vere, Earl of Oxford, the Man who was Shakespeare. New York: Gotham Books, 2005.

Amussen, Susan Dwyer. An Ordered Society: Gender and Class in Early Modern England. New York: Columbia University Press, 1993.

Axton, Marie. The Queen's Two Bodies: Drama and the Elizabethan Succession. London: Royal Historical Society, 1977.

Baert, Barbara. "Around the Sieve. Motif, Symbol, Hermeneutic." Textile 17 (2019): 6-26.

Bagley, J. J. The Earls of Derby 1485-1985. London: Sidgwick \& Jackson, 1985.

Barroll, Leeds. Anna of Denmark, Queen of England: A Cultural Biography. Philadelphia: University of Pennsylvania Press, 2001.

Barrow, Lorna G. "'the Kynge sent to the Qwene, by a Gentylman, a grett tame Hart', Marriage, Gift Exchange, and Politics: Margaret Tudor and James IV 1502-13." Parergon 21 (2004): 65-84.

Bates, Catherine. The Rhetoric of Courtship in Elizabethan Language and Literature. Cambridge: Cambridge University Press, 1992. 
Beik, William. Absolutism and Society in Seventeenth-Century France: State Power and Provincial Aristocracy in Languedoc. Cambridge: Cambridge University Press, 1985.

Bell, H. E. An Introduction to the History and Records of the Court of Wards and Liveries. Cambridge: Cambridge University Press, 1953.

Bellany, Alastair. The Politics of Court Scandal in Early Modern England. Cambridge: Cambridge University Press, 2002.

Bernard, G. W. Power and Politics in Tudor England. Aldershot: Ashgate, 2000.

Bevington, David, and Peter Holbrook, eds. The Politics of the Court Masque. Cambridge: Cambridge University Press, 1998.

Black, Jane. Absolutism in Renaissance Milan: Plenitude of Power under the Visconti and Sforza 1329. 1535. Oxford: Oxford University Press, 2009.

Blackstone, William. Commentaries on the Laws of England. Edited by William Carey Jones. Vol. 1. San Francisco: Bancroft-Whitney Company, 1916.

Bloch, Marc. The Royal Touch: Sacred Monarchy and Scrofula in England and France. Translated by J. E. Anderson. London: Routledge and Kegan Paul, 1973.

Bond, Edward A. Russia at the Close of the Sixteenth Century. London: T. Richards, 1856.

Bradford, Charles Angell. Helena, Marchioness of Northampton. London: s.n., 1936.

British Library. "Portrait of Lady Arbella Stuart, 1589." Accessed 13 November 2019. https://www.bl.uk/collection-items/portrait-of-lady-arbella-stuart-1589\#.

-----. "The Duchess of Malfi." Accessed 13 November 2019. https://www.bl.uk/collectionitems/ / /link.aspx? id=9ED04C5D53EB41489B9373296BD3E4CC\& Z=Z.

Brown, Keith M. Kingdom or Province? Scotland and the Regal Union, 1603-1715. New York: St. Martin's Press, 1992.

-----. Noble Power in Scotland from the Reformation to the Revolution. Edinburgh: Edinburgh University Press, 2011.

-----. Noble Society in Scotland: Wealth, Family and Culture, from Reformation to Revolution. Edinburgh: Edinburgh University Press, 2000.

----. "The Scottish Aristocracy, Anglicization and the Court, 1603-38." HJ 36 (1993): 543-576.

Burgess, Glenn. "The Divine Right of Kings Reconsidered." EHR 107 (1992): 837-861.

Calderwood, David. The History of the Kirk of Scotland. Edited by Thomas Thomson. Vols. 4-8 (15831625). Edinburgh: Printed for the Wodrow Society, 1843-1845.

Canning, J. P. “Law, Sovereignty and Corporation Theory, 1300-1450.” In The Cambridge History of Medieval Political Thought, c.350-c.1450. Edited by J. H. Burns, 454-476. Cambridge: Cambridge University Press, 1988.

Carlisle, Nicholas. An Inquiry into the Place and Quality of the Gentlemen of His Majesty's Most Honourable Privy Chamber. London: Messrs. Payne and Foss, 1829.

Carlson, Eric Josef. Marriage and the English Reformation. Oxford: Blackwell Publishers, 1994.

Cathcart, Alison. “Crisis of Identity? Clan Chattan's Response to Government Policy in the Scottish Highlands c. 1580-1609." In Fighting for Identity: Scottish Military Experience c. 1550-1900. Edited by Steve Murdoch and Andrew MacKillop, 163-184. Leiden: Brill, 2002.

Chambers, E. K. The Elizabethan Stage. Vol. 4. Oxford: Clarendon Press, 1923.

Chapman, Hester W. Two Tudor Portraits: Henry Howard, Earl of Surrey and Lady Katherine Grey. Boston and Toronto: Little, Brown and Company, 1960.

Cobbett, William. Cobbett's Parliamentary History of England. Vol. 1 (1066-1803). London: R. Bagshaw, 1806.

Codrington, Robert. The Life and Death, of the Illustrious Robert Earle of Essex. London: Printed by F. Leach, for L. Chapman, 1646. EEBO.

Cokayne, George Edward, ed. The Complete Peerage of England, Scotland, Ireland, Great Britain and the United Kingdom Extant, Extinct, or Dormant. New ed. Revised and expanded by Vicary Gibbs, H. A. Doubleday, Duncan Warrand, Lord Howard de Walden, and G. H. White. 13 vols. 1910-1959. Reprint, Gloucester: Alan Sutton Publishing Limited, 1984.

Cole, Mary Hill. The Portable Queen: Elizabeth I and the Politics of Ceremony. Amherst: University of Massachusetts Press, 1999.

Collinson, Patrick. Elizabethans. 2nd ed. London and New York: Hambledon and London: 2003.

-----. The Religion of Protestants: The Church in English Society, 1559-1625. Oxford: Clarendon Press, 1982. 
-----. This England: Essays on the English Nation and Commonwealth in the Sixteenth Century. Manchester and New York: Manchester University Press, 2011.

Connolly, Annaliese, and Lisa Hopkins, eds. Goddesses and Queens: The Iconography of Elizabeth I. Manchester: Manchester University Press, 2007.

Cooper, Tarnya. "Queen Elizabeth's Public Face." History Today 53 (2003): 38-41.

Cooper, Tarnya, and Jane Eade, eds. Elizabeth I and Her People. London: National Portrait Gallery, 2013.

Courtney, Alexander. "The Scottish King and the English Court: The Secret Correspondence of James VI, 1601-3." In Doubtful and Dangerous: The Question of Succession in Late Elizabethan England. Edited by Susan Doran and Paulina Kewes, 134-151. Manchester: Manchester University Press, 2014.

Coward, Barry. The Stanleys, Lords Stanley and Earls of Derby, 1385-1672. Chetham Society. Manchester: Manchester University Press, 1983.

Crawford, A. W. C. L., Lord Lindsay. Lives of the Lindsays; or A Memoir of the Houses of Crawford and Balcarres. Vol. 1. Wigan: C. S. Simms, 1840.

Cressy, David. Birth, Marriage and Death: Ritual, Religion, and the Life-Cycle in Tudor and Stuart England. Oxford: Oxford University Press, 1999.

-----. "Gender Trouble and Cross-Dressing in Early Modern England." Journal of British Studies 35 (1996): 438-465.

Croft, Pauline. King James. Basingstoke: Palgrave Macmillan, 2003.

----. "Fresh Light on Bate's Case." HJ 30 (1987): 523-539.

Cross, Claire. The Puritan Earl: The Life of Henry Hastings, Third Earl of Huntingdon, 1536-1595. London: Macmillan, 1966.

Cuddy, Neil. "Anglo-Scottish Union and the Court of James I, 1603-25." TRHS, 5th Series 39 (1989): 107-124.

----. "The Revival of the Entourage: The Bedchamber of James I (1603-1625)." In The English Court: From the Wars of the Roses to the Civil War. Edited by David Starkey, 173-225. London: Longman, 1987.

Curran, Kevin. "Erotic Policy: King James, Thomas Campion, and the Rhetoric of Anglo-Scottish Marriage." Journal for Early Modern Cultural Studies 7 (2007): 55-77.

----. Marriage, Performance, and Politics at the Jacobean Court. Farnham: Ashgate, 2009.

Cust, Elizabeth. Some Account of the Stuarts of Aubigny, in France: 1422-1672. London: Chiswick Press, 1891.

Dale, Bryan. The Good Lord Wharton: His Family, Life, and Bible Charity. New ed. London: Congregational Union of England and Wales, 1906.

Davis, Natalie Zemon. The Gift in Sixteenth-Century France. Oxford: Oxford University Press, 2000.

Dee, Darryl. Expansion and Crisis in Louis XIV's France: Franche-Comté and Absolute Monarchy, 16741715. Cambridge: Cambridge University Press, 2009.

De Fonblanque, Edward Barrington. Annals of the House of Percy. Vol. 2/1. London: Printed by Richard Clay \& Sons for Private Circulation Only, 1887.

De Lisle, Leanda. "Katherine Grey: Heir to Elizabeth," History Today 59 (2009): 23-29.

----. The Sisters Who Would Be Queen: The Tragedy of Mary, Katherine and Lady Jane Grey. London: Harper Press, 2008.

Doelman, James. King James I and the Religious Culture of England. Cambridge: D. S. Brewer, 2000.

Dolan, Frances E. "Gender and Sexuality in Early Modern England." In Gender, Power and Privilege in Early Modern Europe. Edited by Jessica Munns and Penny Richards, 7-20. London and New York: Routledge, 2014.

Doran, Susan. “Did Elizabeth's Gender Really Matter?” In Queens Matter in Early Modern Studies. Edited by Anna Riehl Bertolet, 31-52. Cham: Palgrave Macmillan, 2018.

----. Elizabeth I and Foreign Policy 1558-1603. London and New York: Routledge, 2000.

----. Elizabeth I and Her Circle. Oxford: Oxford University Press, 2015.

----.. Elizabeth I and Religion, 1558-1603. London and New York: Routledge, 1994.

----. "Elizabeth I: Gender, Power \& Politics." History Today 53 (2003): 29-35.

----. "Elizabeth I's Religion: The Evidence of Her Letters," Journal of Ecclesiastical History 51 (2000): 699-720. 
----. Monarchy and Matrimony: The Courtships of Elizabeth I. London and New York: Routledge, 1996.

Doran, Susan, and Thomas S. Freeman, eds. Mary Tudor: Old and New Perspectives. Basingstoke: Palgrave Macmillan, 2011.

Doran, Susan, and Norman Jones, eds. The Elizabethan World. London and New York: Routledge, 2011.

Doran, Susan, and Paulina Kewes, eds. Doubtful and Dangerous: The Question of Succession in Late Elizabethan England. Manchester and New York: Manchester University Press, 2014.

Durant, David N. Arbella Stuart: A Rival to the Queen. London: Weidenfeld and Nicolson, 1978.

----. Bess of Hardwick: Portrait of an Elizabethan Dynast. Rev. ed. London: Peter Owen Publishers, 1999.

Durkan, John. "James, Third Earl of Arran: The Hidden Years." SHR 65 (1986): 154-166.

E. S. "An Unpublished Letter of Robert Dudley, Earl of Leicester, 1564." Notes and Queries 6 (1881): 283-284.

Elliott, J. H. Scots \& Catalans: Union \& Disunion. New Haven and London: Yale University Press, 2018.

Elton, G. R. England under the Tudors. $3^{\text {rd }}$ ed. London and New York: Routledge, 1991.

----. The Parliament of England, 1559-1581. Cambridge: Cambridge University Press, 1986.

Enis, Cathryn. "The Dudleys, Sir Christopher Hatton and the Justices of Elizabethan Warwickshire." Midland History 39 (2014): 1-35.

Estill, Laura. "New Contexts for Early Tudor Plays: William Briton, an Early Reader of Gorboduc." Early Theatre 16 (2013): 197-210.

Farrell, Henry. "Trust, Distrust, and Power." In Distrust. Edited by Russell Hardin, 85-105. New York: Russell Sage Publications, 2004.

Ferguson, Niall. The Square and the Tower: Networks and Power, from the Freemasons to Facebook. New York: Penguin Press, 2018.

Ferguson, Richard S. A History of Cumberland. London: Elliot Stock, 1890.

Ferrell, Lori Anne. "The Sacred, the Profane, and the Union: Politics of Sermon and Masque at the Court Wedding of Lord and Lady Hay." In Politics, Religion, and Popularity in Early Stuart Britain: Essays in Honour of Conrad Russell. Edited by Thomas Cogswell, Richard Cust, and Peter Lake, 45-64. Cambridge: Cambridge University Press, 2002.

Ferris, John P., and Rosemary Sgroi. "WHARTON, Sir Thomas (c.1588-1622), of Wharton Hall, Kirkby Stephen, Westmld. and Aske, Easby, Yorks." The History of Parliament. Accessed 9 March 2020. http://www.historyofparliamentonline.org/volume/1604-1629/member/whartonsir-thomas-1588-1622\#footnote6 dbpa6sy.

Figgis, John Neville. The Divine Right of Kings. 2nd ed. Cambridge: Cambridge University Press, 1914.

Fischlin, Daniel. "Political Allegory, Absolutist Ideology, and the 'Rainbow Portrait' of Queen Elizabeth I." Renaissance Quarterly 50 (1997): 175-206.

Fitzalan-Howard, Henry Granville, duke of Norfolk. The Lives of Philip Howard, Earl of Arundel, and of Anne Dacres, His Wife. London: Hurst and Blackett, 1857.

Fletcher, Anthony, and Diarmaid MacCulloch. Tudor Rebellions. London: Longmans, 1968. Reprint, Harlow: Pearson Education Limited, 2008.

Fogle, French R., and Louis A. Knafla. Patronage in Late Renaissance England. Los Angeles: William Andrews Clark Memorial Library, University of California, 1983.

Fraser, William. The Lennox: Memoirs (1100-1600). Vol. 1. Edinburgh: s.n., 1874.

Freedman, Sylvia. Poor Penelope: Lady Penelope Rich, An Elizabethan Woman. Windsor: Kenseal Press, 1983.

Fuidge, N. M. "TRENTHAM, Thomas I (1538-87), of Rocester, Staffs." The History of Parliament. Accessed 30 November 2019. http://www.historyofparliamentonline.org/volume/15581603/member/trentham-thomas-i-1538-87.

Galloway, Bruce R. The Union of England and Scotland, 1603-1608. Edinburgh: John Donald, 1986.

Gardiner, Samuel R. History of England from the Accession of James I to the Outbreak of Civil War, 1603-1642. New ed. Vol. 3. London: Longmans, Green, and Co., 1890.

Geary, Patrick. "Sacred Commodities: The Circulation of Medieval Relics." In The Social Life of Things: Commodities in Cultural Perspective. Edited by Arjun Appadurai, 169-191. Cambridge: Cambridge University Press, 1986. 
Goodare, Julian. "Scottish Politics in the Reign of James VI." In The Reign of James VI. Edited by Julian Goodare and Michael Lynch, 32-54. East Linton: Tuckwell Press, 2000.

-----. The Government of Scotland, 1560-1625. Oxford: Oxford University Press, 2004.

Goodare, Julian, and Michael Lynch, eds. The Reign of James VI. East Linton: Tuckwell Press, 2000.

Goodman, Godfrey. The Court of King James I. Edited by John S. Brewer. 2 vols. London: Richard Bentley, 1839.

Gordon, Charles, XI Marquis of Huntly, ed. The Records of Aboyne, MCCXXX-MDCLXXXI. New Spalding Club. Aberdeen: Milne and Hutchison, 1894.

Grant, Ruth. "Friendship, Politics and Religion: George Gordon, Sixth Earl of Huntly and King James VI, 1581-1595." In James VI and Noble Power in Scotland 1578-1603. Edited by Miles KerrPeterson and Steven J. Reid, 57-80. London and New York: Routledge, 2017.

----.. "Politicking Jacobean Women: Lady Ferniehirst, the Countess of Arran and the Countess of Huntly, c.1580-1603." In Women in Scotland c.1100-c.1750. Edited by Elizabeth Ewan and Maureen M. Meikle, 95-104. East Linton: Tuckwell Press, 1999.

-----. "The Brig o' Dee Affair, the Sixth Earl of Huntly and the Politics of the Counter-Reformation." In The Reign of James VI. Edited by Julian Goodare and Michael Lynch, 93-109. East Lothian: Tuckwell Press, 2000.

Gregory, Chris A. Gifts and Commodities. London: Academic Press, 1982.

Grierson, Philip. "Commerce in the Dark Ages: A Critique of the Evidence." TRHS 9 (1959): 123-140. Griffin, Richard, Baron Braybrooke. The History of Audley End. To Which are Appended Notices of the Town and Parish of Saffron Walden in the County of Essex. London: Samuel Bentley, 1836.

Groundwater, Anna. "He 'made them friends in his cabinet': James VI's Suppression of the Scott-Ker Feud." In James VI and Noble Power in Scotland 1578-1603. Edited by Miles Kerr-Peterson and Steven J. Reid, 98-116. London and New York: Routledge, 2017.

Gunther, Karl. Reformation Unbound: Protestant Visions of Reform in England, 1525-1590. Cambridge: Cambridge University Press, 2014.

Guy, John. Elizabeth: The Forgotten Years. New York: Viking, 2016.

Guy, John, ed. The Reign of Elizabeth I: Court and Culture in the Last Decade. Cambridge: Cambridge University Press, 1995.

-----. The Tudor Monarchy. London: Arnold, 1997.

Hacket, John. Bishop Hacket's Memoirs of the Life of Archbishop Williams. London: Sam Briscoe, 1715.

Haigh, Christopher. English Reformations: Religion, Politics, and Society Under the Tudors. Oxford: Oxford University Press, 1993.

Hall, Jill M. "Elizabeth's Symbolic Marriage to England: A History of Lasting Union." Early English Studies 1 (2008): 1-15.

Hallen, A. W. Cornelius. The Registers of St. Botolph, Bishopsgate, London. Vol. 1. Edinburgh: T. and A. Constable, 1889.

Hammer, Paul E. J. "Royal Marriage and the Royal Succession." In A Concise Companion to English Renaissance Literature. Edited by Donna B. Hamilton. Malden and Oxford: Blackwell, 2006.

----.. "Sex and the Virgin Queen: Aristocratic Concupiscence and the Court of Elizabeth I." SCJ 31 (2000): 77-97.

Hanley, Sarah. "Engendering the State: Family Formation and State Building in Early Modern France." French Historical Studies 16 (1989): 4-27.

Harris, Barbara J. English Aristocratic Women, 1450-1550: Marriage and Family, Property and Career. Oxford: Oxford University Press, 2002.

----. "Women and Politics in Early Tudor England." HJ 33 (1990): 259-281.

Hartley, T. E. Elizabeth's Parliaments: Queen, Lords and Commons, 1559-1601. Manchester and New York: Manchester University Press, 1992.

Hayward, John, Sir. Annals of the First Four Years of the Reign of Queen Elizabeth. Edited by John Bruce. Camden Society. London: J. B. Nichols and Son, 1840.

Hazard, Mary E. Elizabethan Silent Language. Lincoln and London: University of Nebraska Press, 2000.

Head, David M. "'Beyng Ledde and Seduced by the Devyll': The Attainder of Lord Thomas Howard and the Tudor Law of Treason." SCJ 13 (1982): 3-16.

Heal, Felicity. The Power of Gifts: Gift Exchange in Early Modern England. Oxford: Oxford University Press, 2014. 
Hernández, Ignacio Atienza. "'Refeudalisation' in Castile during the Seventeenth Century: A Cliché?" In The Castilian Crisis of the Seventeenth Century: New Perspectives on the Economic and Social History of Seventeenth-Century Spain. Edited by I. A. A. Thompson and Bartolomé Yun Casalilla, 249-276. Cambridge: Cambridge University Press, 1994.

Heywood, Thomas. The Stanley Papers, Part I: The Earls of Derby and the Verse Writers and Poets of the Sixteenth and Seventeenth Centuries. Chetham Society. Manchester: Charles Simms and Co., 1853.

Hill, Robert, and Roger Lockyer. "'Carleton and Buckingham: The Quest for Office' Revisited." History 88 (2003): 17-31.

Hille, Christiane. Visions of the Courtly Body: The Patronage of George Villiers, First Duke of Buckingham, and the Triumph of Painting at the Stuart Court. Munich: Akademie Verlag, 2013.

Holdsworth, W. S. A History of English Law. 3rd ed. Vol. 3. London: Methuen \& Co. Ltd, 1923.

Hollings, Stephen. "Court Patronage, County Governors and the Early Stuart Parliaments." Parergon 6 (1988): 121-135

Holmes, Rachel E. "A Widow's Will: Adapting the Duchess of Amalfi in Early Modern England and Spain." Studies in Philology 116 (2019): 728-757.

Hopkins, Lisa, ed. Bess of Hardwick: New Perspectives. Manchester: Manchester University Press, 2019.

Houlbrooke, Ralph Anthony. James VI and I: Ideas, Authority, and Government. Aldershot: Ashgate, 2006.

Hoyle, R. W. "The Masters of Requests and the Small Change of Jacobean Patronage." EHR 126 (2011): 544-581.

Hufton, Olwen H. The Prospect before Her: A History of Women in Western Europe. New York: Knopf, 1996.

Hurstfield, Joel. Freedom, Corruption and Government in Elizabethan England. London: Jonathan Cape, 1973.

----.. "Lord Burghley as Master of the Court of Wards, 1561-98." TRHS 31 (1949): 95-114.

----.. The Queen's Wards: Wardship and Marriage under Elizabeth I. $2^{\text {nd }}$ ed. London: Frank Cass, 1973.

----.. "The Revival of Feudalism in Early Tudor England." History 37 (1952): 131-145.

Ives, Eric. Lady Jane Grey: A Tudor Mystery. Chichester: Wiley-Blackwell, 2009.

Jack, Sybil M. "National Identities within Britain and the Proposed Union in 1603-1607." Parergon 18 (2001): 75-101.

James, Henry, and Greg Walker. “The Politics of Gorboduc." EHR 10 (1995): 109-121.

James, Mervyn. Society, Politics and Culture: Studies in Early Modern England. Cambridge: Cambridge University Press, 1986.

Jones, Norman. "Living the Reformations: Generational Experience and Political Perception in Early Modern England." Huntington Library Quarterly 60 (1997): 273-288.

-----. The Birth of the Elizabethan Age: England in the 1560s. Paperback ed. Oxford: B. Blackwell, 1995.

Kantorowicz, Ernst H. "Mysteries of State: An Absolutist Concept and Its Late Mediaeval Origins." Harvard Theological Review 48 (1955): 65-91.

-----. The King's Two Bodies: A Study in Medieval Political Theology. 1957. Reprint, with a preface by William Chester Jordan, Princeton: Princeton University Press, 1997.

Kelly, Joan. Women, History \& Theory: The Essays of Joan Kelly. Chicago and London: University of Chicago Press, 1984.

Kenny, Robert W. Elizabeth's Admiral: The Political Career of Charles Howard, Earl of Nottingham, 1536-1624. Baltimore and London: The Johns Hopkins Press, 1970.

Kerr-Peterson, Miles, and Steven J. Reid, eds. James VI and Noble Power in Scotland 1578-1603. London and New York: Routledge, 2017.

Kesselring, K. J. "'A Cold Pye for the Papistes': Constructing and Containing the Northern Rising of 1569." Journal of British Studies 43 (2004): 417-443.

----. "Mercy and Liberality: The Aftermath of the 1569 Northern Rebellion." History 90 (2002): 213235.

-----. The Northern Rebellion of 1569. Basingstoke: Palgrave Macmillan, 2007. 
Kettering, Sharon. "Brokerage at the Court of Louis XIV." HJ 36 (1993): 69-87.

----. "Gift-giving and Patronage in Early Modern France." French History 2 (1988): 131-151.

----. Patrons, Brokers, and Clients in Seventeenth-Century France. New York and Oxford: Oxford University Press, 1986.

----. "The Historical Development of Political Clientelism." The Journal of Interdisciplinary History 18 (1988): 419-447.

King, Thomas William, ed. Lancashire Funeral Certificates. Manchester: Printed for the Chetham Society, 1869.

Kinney, Arthur F., ed. Titled Elizabethans: A Directory of Elizabethan Court, State, and Church Officers, 1558-1603. $2^{\text {nd }}$ ed. Revised and expanded by Jane A. Lawson. New York: Palgrave Macmillan, 2014.

Larson, Deborah Welch. "Distrust: Prudent, If Not Always Wise." In Distrust. Edited by Russell Hardin, 34-59. New York: Russell Sage Foundation, 2004.

Lawson, Jane A. "Bess of Hardwick and Elizabeth St Loe." Notes and Queries 61 (2014): 206-211.

Lawson-Peebles, Robert. "A Conjoined Commonwealth: The Implications of the Accession of James VI and I." The Yearbook of English Studies 46 (2016): 56-74.

Levack, Brian P. The Formation of the British State: England, Scotland and the Union, 1603-1707. Oxford: Oxford University Press, 1987.

Levin, Carole. The Heart and Stomach of a King: Elizabeth I and the Politics of Sex and Power. $2^{\text {nd }}$ ed. Philadelphia: University of Pennsylvania Press, 2013.

Levine, Mortimer. The Early Elizabethan Succession Question, 1558-1568. Stanford: Stanford University Press, 1966.

Lindley, David. “Campion's 'Lord Hay’s Masque' and Anglo-Scottish Union.” Huntingdon Library Quarterly 43 (1979): 1-11.

----. “Embarrassing Ben: The Masques for Frances Howard.” English Literary Renaissance 16 (1986): 343-359.

----. The Trials of Frances Howard. London and New York: -Routledge, 1993.

----. “Who Paid for Campion's 'Lord Hay's Masque'?” Notes \& Queries 26 (1979): 144-145.

Lindley, David, ed. The Court Masque. Manchester: Manchester University Press, 1984.

Lindquist, Eric. "The Failure of the Great Contract." The Journal of Modern History 57 (1985): 617-651.

Loades, David. Politics, Censorship and the English Reformation. London and New York: Pinter Publishers, 1991.

----. The Cecils: Privilege and Power Behind the Throne. Kew: The National Archives, 2007.

Locke, A. Audrey. The Seymour Family, History and Romance. London: Constable and Company Ltd., 1911.

Lockyer, Roger. Buckingham: The Life and Political Career of George Villiers, First Duke of Buckingham, 1592-1628. London and New York: Longman, 1981.

----.. "James VI \& I." History Review 5 (1999): 8-13.

----. Tudor and Stuart Britain, 1485-1714. 3rd ed. London: Routledge, 2014.

Lomas, Richard. A Power in the Land: The Percys. Edinburgh: Tuckwell Press Ltd, 1999.

Loughlin, Marie H. "Love's Friend and Stranger to Virginitie': The Politics of the Virginal Body in Ben Jonson's Hymenæi and Thomas Campion's The Lord Hay's Masque." ELH 63 (1996): 833-849.

Lovejoy, Arthur O. The Great Chain of Being: A Study of the History of an Idea. Cambridge: Harvard University Press, 1936. Reprint, Cambridge: Harvard University Press, 1964.

MacCaffrey, Wallace T. Elizabeth I: War and Politics, 1588-1603. Princeton: Princeton University Press, 1992.

-----. "Place and Patronage in Elizabethan Politics." In Elizabethan Government and Society: Essays Presented to Sir John Neale. Edited by S. T. Bindoff, J. Hurstfield, and C. H. Williams, 95-126. London: University of London, 1961.

-----. Queen Elizabeth and the Making of Policy, 1572-1588. Princeton: Princeton University Press, 1981.

-----. The Shaping of the Elizabethan Regime: Elizabethan Politics, 1558-1572. Princeton: Princeton University Press, 1968.

Macculloch, Diarmaid. "Catholic and Puritan in Elizabethan Suffolk: A County Community Polarises." Archiv für Reformationsgeschichte 72 (1981): 232-289.

----. "Putting the English Reformation on the Map." TRHS 15 (2005): 75-95. 
-----. "Sixteenth-century English Protestantism and the Continent." In Sister Reformations: The Reformation in Germany and in England. Edited by Dorothea Wendebourg, 1-14. Tübingen: Mohr Siebeck, 2010.

-----. Suffolk and the Tudors: Politics and Religion in an English County 1500-1600. Oxford: Oxford University Press, 1986.

----.. "The Myth of the English Reformation." Journal of British Studies 30 (1991): 1-19.

MacDonald, Alan R. The Jacobean Kirk, 1567-1625: Sovereignty, Polity and Liturgy. Aldershot: Ashgate, 1998.

Macinnes, Allan I. "Regal Union for Britain, 1603-38." In The New British History: Founding a Modern State, 1603-1715. Edited by Glenn Burgess, 33-64. London and New York: I. B. Tauris Publishers, 1999.

MacQueen, Hector L. Common Law and Feudal Society in Medieval Scotland. Edinburgh: Edinburgh University Press, 1993.

Mason, Roger. "1603: Multiple Monarchy and Scottish Identity." History 105 (2020): 402-421.

----. "Posing the East Lothian Question." History Scotland 8 (2008): 40-48.

----.. "Scotland, Elizabethan England and the Idea of Britain." TRHS 14 (2004): 279-293.

Mason, Roger, ed. Scotland and England 1286-1815. Edinburgh: John Donald, 1987.

----. Scots and Britons: Scottish Political Thought and the Union of 1603. Cambridge: Cambridge University Press, 1994.

Mauss, Marcel. The Gift: The Form and Reason for Exchange in Archaic Societies. Translated by Ian Cunnison. 1950. Reprint, with an introduction by E. E. Evans-Pritchard, London: Cohen \& West Ltd, 1966.

Mayer, Jean-Christophe, ed. The Struggle for the Succession in Late Elizabethan England: Politics, Polemics and Cultural Representations. With a preface by Jenny Wormald. Astraea Collection, no. 11. Montpellier: Institut de Recherche sur la Renaissance, 2004.

McCormack, Daniel. Great Powers and International Hierarchy. Cham: Palgrave Macmillan, 2019.

McLaren, Anne. "The Quest for a King: Gender, Marriage, and Succession in Elizabethan England." Journal of British Studies 41 (2002): 259-290.

McLaughlin, Adrienne. "Rise of a Courtier: The Second Duke of Lennox and Strategies of Noble Power under James VI." In James VI and Noble Power in Scotland 1578-1603. Edited by Miles KerrPeterson and Steven J. Reid, 136-154. London and New York: Routledge, 2017.

Mears, Natalie. "Courts, Courtiers, and Culture in Tudor England." HJ 46 (2003): 703-722.

----.. "Love-making and Diplomacy: Elizabeth I and the Anjou Marriage Negotiations, c.1578-1582." History 86 (2001): 442-466.

Meikle, Maureen M. "The Invisible Divide: The Greater Lairds and the Nobility of Jacobean Scotland." SHR 71 (1992): 70-87.

Merriman, M. H. "The Assured Scots: Scottish Collaborators with England during the Rough Wooing." SHR 47 (1968): 10-34.

-----. The Rough Wooings: Mary Queen of Scots, 1542-1551. East Lothian: Tuckwell Press, 2000.

Miller, John, ed. Absolutism in Seventeenth Century Europe. Basingstoke and London: Macmillan, 1990.

Montrose, Louis. "Elizabeth through the Looking Glass: Picturing the Queen's Two Bodies." In The Body of the Queen: Gender and Rule in the Courtly World, 1500-2000. Edited by Regina Schulte, 61-87. New York and Oxford: Berghahn Books, 2006.

Morrieson, H. W. "The English Silver Coins of James I." The British Numismatic Journal 4 (1907): 165178.

Mortimer, Ian. 1415: Henry V's Year of Glory. 2009. Reprint, London: Vintage Books, 2010.

----. The Time Traveler's Guide to Elizabethan England. New York: Penguin Books, 2012.

Mueller, Janel. "'To My Very Good Brother the King of Scots': Elizabeth I's Correspondence with James VI and the Question of the Succession." PMLA 115 (2000): 1063-1071.

Mulryne, J. R., and Margaret Shewring, eds. Theatre and Government Under the Early Stuarts. Cambridge: Cambridge University Press, 1993.

Neale, J. E. Elizabeth I and Her Parliaments. 2 vols. London: Jonathan Cape, 1953-1957.

----. Essays in Elizabethan History. London: Cape, 1958. 
Nelson, Alan H. Monstrous Adversary, The Life of Edward de Vere, 17th Earl of Oxford. Liverpool: Liverpool University Press, 2003.

Nenner, Howard. The Right to be King: The Succession to the Crown of England, 1603-1714. Basingstoke: Macmillan Press Ltd, 1995.

Newton, Diana. "Francis Hastings and the Religious Education of James VI and I." HJ 41 (1998): 917934.

O'Day, Rosemary. The Family and Family Relationships, 1500-1900. New York: St. Martin's Press, 1994.

O'Day, Rosemary, and Felicity Heal, eds. Continuity and Change: Personnel and Administration of the Church of England 1500-1642. Leicester: Leicester University Press, 1976.

Oestreich, Gerhard. Neostoicism and the Early Modern State. Edited Brigitta Oestreich and H. G. Koenigsberger and translated by David McLintock. Cambridge: Cambridge University Press, 1982.

Orgel, Stephen. The Illusion of Power: Political Theatre in the English Renaissance. Berkeley: University of California Press, 1975.

Oxford Dictionary of National Biography. Online ed. Oxford and New York: Oxford University Press, 2004-2019. http://www.oxforddnb.com/.

Oxford English Dictionary. Online ed. Oxford: Oxford University Press, 2020. http://www.oed.com.

Parker, David. Class and State in Ancien Régime France: The Road to Modernity? London: Routledge, 1996.

Paul, James Balfour, Sir, ed. The Scots Peerage. Founded on Wood's Edition of Sir Robert Douglas's Peerage of Scotland. 9 vols. Edinburgh: David Douglas, 1904-1914.

Pearson, Daphne. Edward de Vere (1550-1604): The Crisis and Consequences of Wardship. Aldershot: Ashgate, 2005.

Peck, Linda Levy. Court Patronage and Corruption in Early Stuart England. Boston: Unwin Hyman, 1990. Reprint, London and New York: Routledge, 1993.

-----. "Court Patronage and Government Policy: The Jacobean Dilemma." In Patronage in the Renaissance. Edited by Guy Fitch Lytle and Stephen Orgel, 27-46. Princeton: Princeton University Press, 1981.

----. Northampton: Patronage and Policy at the Court of James I. London: George Allen \& Unwin, 1982.

----. "'For a King Not to be Bountiful Were a Fault': Perspectives on Court Patronage in Early Stuart England." Journal of British Studies 25 (1986): 31-61.

Peck, Linda Levy, ed. The Mental World of the Jacobean Court. Cambridge: Cambridge University Press, 1991.

Pennington, K. "Law, Legislative Authority, and Theories of Government, 1150-1300." In The Cambridge History of Medieval Political Thought, c.350-c.1450. Edited by J. H. Burns, 424-453. Cambridge: Cambridge University Press, 1988.

Plowden, Alison. Marriage with My Kingdom: The Courtships of Queen Elizabeth I. London and Basingstoke: Macmillan London Limited, 1977.

Plowden, Edmund. The Commentaries, or Reports of Edmund Plowden, of the Middle-Temple, Esq. Vol. 1. Dublin: Printed for H. Watts, 1792. ECCO.

Raumer, Frederick von, ed. History of the Sixteenth and Seventeenth Centuries, Illustrated by Original Sources. Translated by H. E. Lloyd. 2 vols. London: John Murray, 1835.

Rawson, Maud Stepney. Bess of Hardwick and Her Circle. New York: John Lane Company, 1910.

Reid, Steven J. "Of Bairns and Bearded Men: James VI and the Ruthven Raid." In James VI and Noble Power in Scotland 1578-1603. Edited by Miles Kerr-Peterson and Steven J. Reid, 32-56. London and New York: Routledge, 2017.

Reid-Baxter, Jamie. "Politics, Passion and Poetry in the Circle of James VI: John Burel and His Surviving Works." In A Palace in the Wild: Essays on Vernacular Culture and Humanism in Late-Medieval and Renaissance Scotland. Edited by L. A. J. R. Houwen, A. A. MacDonald, and S. L. Mapstone, 199-248. Leuven: Peeters, 2000.

Rickman, Johanna. Love, Lust, and License in Early Modern England: Illicit Sex and the Nobility. Burlington: Ashgate, 2008.

Ross, Emily. "Spin-Doctoring Discourse: Ideological Debates around the Marriage of Lady Arbella Stuart and William Seymour." Comitatus 44 (2013): 187-218. 
Rowland, Daniel. An Historical and Genealogical Account of the Noble Family of Nevill. London: Samuel Bentley, 1830.

Royal Collection Trust. “James I, second coinage, Unite, mintmark rose.” Accessed 3 November 2019. https://www.rct.uk/collection/443085/james-i-second-coinage-unite-mintmark-rose.

Rymer, Thomas. Acta Regia; Being the Account which Mr. Rapin de Thoyras Published of the History of England, ... and Grounded Upon ... Mr. Rymer's Foedera. London: Printed for James, John and Paul Knapton; D. Midwinter; A. Bettesworth and C. Hitch; C. Rivington; J. Pemberton, [and 6 others in London], [1734?]. ECCO.

Russell, Conrad. "Divine Rights in the Early Seventeenth Century." In Public Duty and Private Conscience in Seventeenth-Century England: Essays Presented to G. E. Aylmer. Edited by John Morrill, Paul Slack, and Daniel Woolf, 101-120. Oxford: Clarendon Press, 1993.

-----. James VI and I and His English Parliaments. Edited by Richard Cust and Andrew Thrush. Oxford: Oxford University Press, 2011.

Rutton, W. L. "Lady Katherine Grey and Edward Seymour, Earl of Hertford." EHR 13 (1898): 302307.

Sacks, David Harris. "The Counterveiling of Benefits: Monopoly, Liberty, and Benevolence in Elizabethan England.” In Tudor Political Culture. Edited by Dale Hoak, 272-291. Cambridge: Cambridge University Press, 2002.

Sale, Carolyn. "The 'Roman Hand': Women, Writing and the Law in the 'Att.-Gen. v. Chatterton' and the Letters of the Lady Arbella Stuart.” ELH 70 (2003): 929-961.

Schreiber, Roy E. "The First Carlisle: Sir James Hay, First Earl of Carlisle as Courtier, Diplomat and Entrepreneur, 1580-1636." Transactions of the American Philosophical Society 74 (1984): 1202.

Schutte, Kimberly. Women, Rank, and Marriage in the British Aristocracy, 1485-2000: An Open Elite? London: Palgrave Macmillan, 2014.

Scot, John, Sir. The Staggering State of Scottish Statesmen from 1550-1650, With A Memoir of the Author and Historical Illustrations by the Rev. Charles Rogers. Edinburgh: William Paterson, 1872.

Seacome, John. The History of the House of Stanley. Preston: E. Sergent, 1793. ECCO.

Sessions, W. A. Henry Howard the Poet Earl of Surrey: A Life. Oxford: Oxford University Press, 2003.

Sgroi, Rosemary. "1559 Parliament." The History of Parliament. Accessed 26 June 2018. http://www.historyofparliamentonline.org/volume/1558-1603/parliament/1559-0.

-----. "Monopolies in Elizabethan Parliaments." The History of Parliament. Accessed 23 January 2020. https://www.historyofparliamentonline.org/periods/tudors/monopolies-elizabethanparliaments.

-----. "Religious Debates in the Elizabethan Parliaments." The History of Parliament. Accessed 28 November 2019. https://www.historyofparliamentonline.org/periods/tudors/religiousdebates-elizabethan-parliaments.

Sharp, Cuthbert. Memorials of the Rebellion of 1569. London: John Bowyer Nichols and Son, and William Pickering, 1840.

Shaw, Duncan, ed. Reformation and Revolution: Essays Presented to The Very Reverend Principal Emeritus Hugh Watt, D.D., D.Litt., on the Sixtieth Anniversary of his Ordination. Edinburgh: St. Andrew's Press, 1967.

Smith, David L. The Stuart Parliaments 1603-1689. London: Arnold Publishers, 1999.

Smout, T. C., ed. Anglo-Scottish Relations from 1603-1900. Oxford: Oxford University Press for The British Academy, 2005.

Smuts, R. Malcolm, ed. The Stuart Court and Europe: Essays in Politics and Political Culture. Cambridge: Cambridge University Press, 1996.

Somerset, Anne. Unnatural Murder: Poison at the Court of James I. London: Weidenfeld \& Nicolson, 1997.

Sommerville, Johann P. "Early Modern Absolutism in Practice and Theory." In Monarchism and Absolutism in Early Modern Europe. Edited by Cesare Cuttica and Glenn Burgess, 117-130. London: Pickering \& Chatto, 2012.

Southwark Cathedral. "Our History.” Accessed 2 December 2019. https://cathedral.southwark.anglican.org/about/our-history/. 
Spence, Richard T. The Privateering Earl: George Clifford, $3^{\text {rd }}$ Earl of Cumberland, 1558-1605. Stroud: Alan Sutton Publishing, 1995.

Starkey, David. Elizabeth: The Struggle for the Throne. New York: Harper Collins Publishers, 2001.

Steen, Sara Jayne. "The Crime of Marriage: Arbella Stuart and The Duchess of Malfi." SCJ (1991): 6176.

Stewart, Laura A. M. "The Political Repercussions of the Five Articles of Perth: A Reassessment of James VI and I's Religious Policies in Scotland." SCJ 38 (2007): 1013-1036.

Stone, Lawrence. "Marriage among the English Nobility in the $16^{\text {th }}$ and $17^{\text {th }}$ Centuries." Comparative Studies in Society and History 3 (1961): 182-206.

-----. The Crisis of the Aristocracy, 1558-1641. Oxford: Clarendon Press, 1965.

----. The Family, Sex and Marriage in England, 1500-1800. London: Weidenfeld and Nicolson, 1977.

Stone, Lawrence, and Jeanne C. Fawtier Stone. An Open Elite: England 1540-1880. Oxford: Oxford University Press, 1984.

Stopes, Charlotte Carmichael. The Life of Henry, Third Earl of Southampton, Shakespeare's Patron. Cambridge: Cambridge University Press, 1922.

Strickland, Agnes. Life of Mary Queen of Scots. Vol. 2. London: George Bell and Sons, 1903.

----.. Lives of the Queens of Scotland and English Princesses Connected with the Regal Succession of Great Britain. Vol. 2. New York: Harper \& Brothers, Publishers, 1851.

Taylor, Alice. The Shape of the State in Medieval Scotland, 1124-1290. Oxford: Oxford University Press, 2016.

The Metropolitan Museum of Art. "Unite coin of James I (r. 1603-25)." Accessed 3 November 2019. https://www.metmuseum.org/art/collection/search/188484.

Thomas, Nicholas. Entangled Objects: Exchange, Material Culture, and Colonialism in the Pacific. Cambridge and London: Harvard University Press, 1991.

Thomson, A. T. The Life and Times of George Villiers, Duke of Buckingham. Vol. 1. London: Hurst and Blackett, 1860.

Thorpe, S. M. "SPENCER, Sir John (1524-86), of Althorp, Northants. and Wormleighton, Warws." The History of Parliament. Accessed 14 August 2017.

https://www.historyofparliamentonline.org/volume/1509-1558/member/spencer-sirjohn-1524-86.

Thrush, Andrew. "On this Day: 21 November 1606: The Proposed Union between England and Scotland." The History of Parliament. Accessed 7 December 2019.

http://www.historyofparliamentonline.org/periods/stuarts/day-21-november-1606proposed-union-between-england-and-scotland.

-----. "The Parliament of 1604-1610." The History of Parliament. Accessed 23 January 2020. http://www.historyofparliamentonline.org/volume/1604-1629/survey/parliament-16041610.

Tillyard, E. M. W. The Elizabethan World Picture. 1943. Reprint, London: Pimlico, 1998.

Todd, Margo. The Culture of Protestantism in Early Modern Scotland. New Haven and London: Yale University Press, 2002.

Trouillot, Michel-Rolph. Silencing the Past: Power and the Production of History. Boston: Beacon Press, 1995.

Tyacke, Nicholas. Aspects of English Protestantism c. 1530-1700. Manchester and New York: Manchester University Press, 2001.

-----. Anti-Calvinists: The Rise of English Arminianism, c. 1590-1640. Oxford: Oxford University Press, 1990.

Viroli, Maurizio. From Politics to Reason of State. Cambridge: Cambridge University Press, 1992.

Usher, Roland G. The Rise and Fall of the High Commission. 1913. Reprint, with an introduction by Philip Tyler, Oxford: Clarendon Press, 1968.

Waite, P. B. "The Struggle of Prerogative and Common Law in the Reign of James I." The Canadian Journal of Economics and Political Science 25 (1959): 144-152.

Wall, Alison. "For Love, Money, or Politics? A Clandestine Marriage and the Elizabethan Court of Arches." HJ 38 (1995): 511-533.

----. "'Points of Contact': Court Favourites and County Factions in Elizabethan England." Parergon 6 (1988): 215-226. 
----.. "'The Greatest Disgrace': The Making and Unmaking of JPs in Elizabethan and Jacobean England." EHR 119 (2004): 312-332.

Warnicke, Retha M. Mary Queen of Scots. New York: Routledge, 2006.

----. Women of the English Renaissance and Reformation. Westport: Greenwood Press, 1983.

Weikel, Ann. "Sins of the Fathers?: The Marriage of Mary Cornwallis," Recusant History 23 (1996): 16-26.

Weldon, Anthony, Sir. The Court and Character of King James. 1640. Reprint, London: G. Smeeton, 1817.

Whitelock, Anna. Elizabeth's Bedfellows: An Intimate History of the Queen's Court. London: Bloomsbury, 2013.

Wiffen, J. H. Historical Memoirs of the House of Russell. 2 vols. London: Longman, Rees, Orme, Brown, Green, and Longman,1833.

Williams, Deanne. "Dido, Queen of England." ELH 73 (2006): 31-59.

Williams, Neville. Thomas Howard, Fourth Duke of Norfolk. London: Barrie and Rockliff, 1964.

Williamson, George C. George, Third Earl of Cumberland (1558-1605): His Life and His Voyages. Cambridge: Cambridge University Press, 1920.

Willock, John. The Great Marquess: Life and Times of Archibald, $8^{\text {th }}$ Earl, and $1^{\text {st }}$ (and Only) Marquess of Argyll (1607-1661). Edinburgh and London: Oliphant Anderson \& Ferrier, 1903.

Wilson, Arthur. The History of Great Britain, Being the Life and Reign of King James the First, Relating to What Passed from His First Accesse to the Crown, till his Death. London: Richard Lownds, 1653.

Wilson, Derek. The People's Bible: The Remarkable History of the King James Version. Foreward by Diarmaid MacCulloch. Oxford: Lion, 2011.

Wormald, Jenny. 'A Union of Hearts and Minds?' The Making of the Union Between Scotland and England, 1603." Revista Internacional de los Estudios Vascos 5 (2009): 109-124.

----. Court, Kirk, and Community: Scotland 1470-1625. London: Edward Arnold, 1981.

-----. "Gunpowder, Treason, and Scots." Journal of British Studies 24 (1985): 141-168.

----.. Lords and Men in Scotland: The Bonds of Manrent 1442-1603. Edinburgh: John Donald Publishers, Ltd., 1985.

----.. "James VI \& I." History Today 52 (2002): 27-33.

-----. “James VI and I: Two Kings or One?" History 68 (1983): 187-209.

----. "The Creation of Britain: Multiple Kingdoms or Core and Colonies?" TRHS, 6th Series 2 (1992): 175-194.

Young, Michael B. “James VI and I: Time for a Reconsideration?” Journal of British Studies 51 (2012): 540-567. 
